Income \& expenditure of households

Statistical release P0100 


\section{General information}

Statistics South Africa contact information:
Physical address:

170 Andries Street

Pretoria

0002

South Africa

Postal address:

Statistics South Africa

Private Bag X44

Pretoria

0001

South Africa

Main

switchboard:

(012) 3108911

Website:

Tel:

Fax:

Email:

Tel:

Fax:

Email: www.statssa.gov.za

(012) 3108610

(012) 3108501

IES2005@statssa.gov.za

(012) 3108600

(012) 3108500

info@statssa.gov.za 


\title{
Statistical release
}

P0100

\section{Income and expenditure of households}

\section{$2005 / 2006$}

\author{
Embargoed until: \\ 4 March 2008 \\ 10:00 am
}

\section{Enquiries:}

User Information Services

(012) 3108600

Statistics South Africa - Mbalo-mbalo dza Afrika Tshipembe - Tinhlayo-tiko ta Afrika-Dzonga - Dipalopalo tsa Aforika Borwa - Ezezibalo zaseNingizimu Afrika 


\section{General information}

Stats SA publishes approximately 300 different statistical releases each year. It is not economically viable to produce them in more than one of South Africa's eleven official languages. Since the releases are used extensively, not only locally but also by international economic and social-scientific communities, Stats SA releases are published in English only.

Stats SA has copyright on this publication. Users may apply the information as they wish, provided that they acknowledge Stats SA as the source of the basic data wherever they process, apply, utilise, publish or distribute the data; and also that they specify that the relevant application and analysis (where applicable) result from their own processing of the data.

\section{Advance release calendar}

An advance release calendar is disseminated on www.statssa.gov.za

\section{Stats SA products}

A complete set of Stats SA publications is available at the Stats SA Library and the following libraries:

National Library of South Africa, Pretoria Division

National Library of South Africa, Cape Town Division

Natal Society Library, Pietermaritzburg

Library of Parliament, Cape Town

Bloemfontein Public Library

Johannesburg Public Library

Eastern Cape Library Services, King William's Town

Central Regional Library, Polokwane

Central Reference Library, Nelspruit

Central Reference Collection, Kimberley

Central Reference Library, Mmabatho

Stats SA also provides a subscription service.

\section{Electronic services}

A large range of data are available via on-line services, diskette and computer printouts. For more details about our electronic data services, contact (012) 310 8600/8390/8351/4892/8496/8095.

You can visit us on the internet at: www.statssa.gov.za

\section{Enquiries}

Telephone number:

(012) 310 8600/8390/8351/4892/8496/8095 (user information services)

(012) 3108610 (technical enquiries)

(012) 3108161 (orders)

(012) 310 4883/4885/8018 (library)

Fax number:

(012) 3108501 (technical enquiries)

Email address:

IES2005@statssa.gov.za

distribution@statssa.gov.za (orders)

Postal address:

Private Bag X44, Pretoria, 0001

Produced by Stats SA 


\section{Preface}

This statistical release is a selection of key findings and tables based on the data that were collected by Statistics South Africa through the Income and Expenditure Survey (IES) that was carried out during the period September 2005 to August 2006. This release focuses on the income and expenditure patterns of households at national and provincial level.

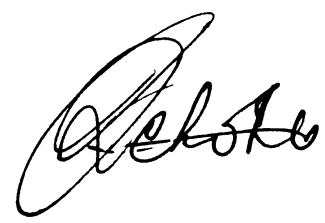

\section{Pali Lehohla}

Statistician-General 


\section{Contents}

1. Introduction 1

1.1 Background of the survey 1

2. Key findings 3

3. Summary of the findings 5

3.1 Household consumption expenditure 5

3.2 Household income 9

4. Findings 13

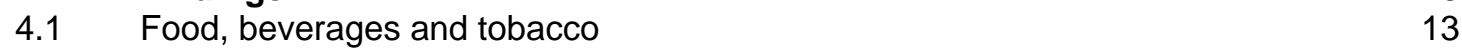

$\begin{array}{lll}4.2 & \text { Clothing and footwear } & 14\end{array}$

4.3 Housing, water, electricity, gas and other fuels 15

4.4 Furnishings, household equipment and routine maintenance of the dwelling 15

$\begin{array}{lll}4.5 & \text { Health } & 17\end{array}$

$\begin{array}{lll}4.6 & \text { Transport } & 18\end{array}$

$\begin{array}{lll}4.7 & \text { Communication } & 19\end{array}$

4.8 Recreation and culture 20

$\begin{array}{lll}4.9 & \text { Education } & 21\end{array}$

4.10 Restaurants and hotels 22

4.11 Miscellaneous goods and services (including personal care and insurance) 23

5. Explanatory notes 24

$\begin{array}{ll}5.1 & \text { Main objectives of the survey } \\ 5.2 & 24\end{array}$

5.2 How the IES 2005/2006 was conducted 24

5.3 The instruments for data collection 24

$\begin{array}{ll}\text { 5.3.1 Main questionnaire } & 25\end{array}$

$\begin{array}{ll}\text { 5.3.2 Weekly diary } & 25\end{array}$

$\begin{array}{ll}\text { 5.3.3 Summary questionnaire } & 25\end{array}$

5.4 Time span 25

$\begin{array}{lll}5.5 & \text { Response details } & 25\end{array}$

$\begin{array}{lll}5.6 & \text { Data } & 26\end{array}$

5.6.1 Data organisation 26

$\begin{array}{ll}5.6 .2 & \text { Imputations } \\ 5.62 .1 & 26\end{array}$

$\begin{array}{ll}\text { 5.6.2.1 Imputing for missing diaries } & 27\end{array}$

$\begin{array}{ll}\text { 5.6.2.2 Imputing for item non-response } & 27\end{array}$

$\begin{array}{ll}\text { 5.6.3 Treatment of special items } & 28\end{array}$

6. Limitations of the survey 30

6.1 Movement of households 30

$\begin{array}{lll}6.2 & \text { Boundary changes } 30\end{array}$

$\begin{array}{lll}\text { 7. Technical notes } & 31\end{array}$

$\begin{array}{lll}7.1 & \text { Sample } & 31\end{array}$

$\begin{array}{lll}7.2 & \text { Coverage } & 31\end{array}$

$\begin{array}{lll}7.3 & \text { Data collection } & 31\end{array}$

7.4 Data processing 32

7.4.1 High level processes 32

7.4.2 Data processing management system and database 32

$\begin{array}{ll}\text { 7.4.3 Coding of acquired items } & 33\end{array}$

7.4.4 Data capturing 33

$\begin{array}{lll}7.4 .5 & \text { Editing } & 33\end{array}$

$\begin{array}{lll}\text { 7.4.6 Quality assurance } & 33\end{array}$ 
$\begin{array}{lll}7.5 & \text { Weighting } & 34\end{array}$

$\begin{array}{lll}7.6 & \text { Reliability of estimates } & 35\end{array}$

$\begin{array}{lll}\text { 7.6.1 Background } & 35\end{array}$

7.6.2 Analysis of coefficients of variation $\quad 35$

$\begin{array}{ll}\text { 8. Definition of terms } & 38\end{array}$

$\begin{array}{ll}\text { 9. Tables } & 42\end{array}$

$\begin{array}{lr}\text { 10. Graphs } & 175\end{array}$

\section{List of tables in findings}

Table A - Main differences between IES 2000 and IES 2005/2006 2

Table B - Total and average household consumption expenditure by main expenditure group and income

Table C - Annual household consumption expenditure on private medical services in South Africa by population group of household head

Table D - Response details for IES 2005/2006

Table E - Mean consumption expenditure by sex of household head with coefficient of variation and confidence intervals for mean expenditure

Table F - Mean consumption expenditure by main expenditure group and mean income with coefficient of variation and confidence intervals for mean expenditure and mean income

Table G - Mean consumption expenditure by province with coefficient of variation and confidence intervals for mean expenditure

Table H - Mean consumption expenditure by population group of household head with coefficient of variation and confidence intervals for mean expenditure

\section{List of graphs in findings}

Figure 1 - Percentage distribution of total annual household consumption expenditure in South Africa by main expenditure group

Figure 2 - Percentage distribution of annual household consumption expenditure on broad expenditure groups by population group of household head

Figure 3 - Average annual household consumption expenditure of South African households by population group of household head

Figure 4 - Distribution of South African households by expenditure quintiles and population group of household head

Figure 5 - Average annual income of South African households by population group of household head

Figure 6 - Distribution of South African households by income quintiles by population group of household head 
Figure 7 - Distribution of annual household income by main income group and sex of household head

Figure 8 - Percentage distribution of annual household income by main income group and population group of household head

Figure 9 - Proportion of total household consumption expenditure attributed to food, beverages and tobacco by population group of household head

Figure 10 - Proportion of total household consumption expenditure attributed to clothing and footwear by province

Figure 11 - Proportion of total household consumption expenditure attributed to housing, water, electricity, gas and other fuels by population group of household head

Figure 12 - Proportion of total household consumption expenditure attributed to furnishings, household equipment, and routine maintenance of the dwelling by settlement type

Figure 13 - Proportion of total household consumption expenditure attributed to transport by population group of household head

Figure 14 - Proportion of total household consumption expenditure attributed to communication by settlement type

Figure 15 - Proportion of total household consumption expenditure attributed to expenditure on recreation and culture by province

Figure 16 - Proportion of total household consumption expenditure attributed to education by population group of household head

Figure 17 - Proportion of total household consumption expenditure attributed to restaurants and hotels by population group of household head

Figure 18 - Proportion of total household consumption expenditure attributed to miscellaneous goods and services by population group of household head

\section{Tables}

1. Population

1.1 Population by province and sex of household head

1.2 Urban population by province and sex of household head

\section{Expenditure}

2.1 Percentage distribution of annual household consumption expenditure

by main expenditure group and population group of household head

2.2 Percentage distribution of annual consumption expenditure by secondary expenditure group and population group of household head

2.3 Percentage distribution of annual household consumption expenditure by third expenditure group and population group of household head

2.4 Percentage distribution of annual household consumption expenditure by main expenditure group and sex of household head

2.5 Percentage distribution of annual household consumption expenditure by secondary expenditure group and sex of household head 
2.6 Percentage distribution of annual household consumption expenditure by third expenditure group and sex of household head

2.7 Percentage distribution of annual household consumption expenditure by main expenditure group and type of settlement

2.8 Percentage distribution of annual household consumption expenditure by secondary expenditure group and type of settlement

2.9 Percentage distribution of annual household consumption expenditure by third expenditure group and type of settlement

2.10 Percentage distribution of annual household consumption expenditure by main expenditure group and expenditure deciles

2.11 Percentage distribution of annual household consumption expenditure by secondary group and expenditure deciles

2.12 Percentage distribution of annual household consumption expenditure by third expenditure group and expenditure deciles

2.13 Percentage distribution of annual household consumption expenditure by main expenditure group and income deciles

2.14 Percentage distribution of annual household consumption expenditure by secondary expenditure group and income deciles

2.15 Percentage distribution of annual household consumption expenditure by third expenditure group and income deciles

2.16 Percentage distribution of annual household consumption expenditure by main expenditure group and province

Percentage distribution of annual household consumption expenditure

Percentage distribution of annual household con
by secondary expenditure group and province

2.18 Percentage distribution of annual household consumption expenditure by third expenditure group and province

2.19 Average household consumption expenditure by main expenditure group and population group of household head

2.20 Average household consumption expenditure by secondary expenditure group and population group of household head

2.21 Average household consumption expenditure by third expenditure group and population group of household head

2.22 Average household consumption expenditure by main expenditure group and sex of household head

2.23 Average household consumption expenditure by secondary expenditure group and sex of household head

2.24 Average household consumption expenditure by third expenditure group and sex of household head

2.25 Average household consumption expenditure by main expenditure group and type of settlement

2.26 Average household consumption expenditure by secondary expenditure group and type of settlement

2.27 Average household consumption expenditure by third expenditure group and type of settlement

2.28 Average household consumption expenditure by main expenditure group and expenditure deciles

2.29 Average household consumption expenditure by secondary expenditure group and expenditure deciles

2.30 Average household consumption expenditure by third expenditure group and expenditure deciles

2.31 Average household consumption expenditure by main expenditure group and income deciles

2.32 Average household consumption expenditure by secondary expenditure group and income deciles

2.33 Average household consumption expenditure by third expenditure group and income deciles 
2.34 Average household consumption expenditure by main expenditure group and province

2.35 Average household consumption expenditure by secondary expenditure group and province

2.36 Average household consumption expenditure by third expenditure group and province

3. Income

3.1 Average household income by main income group and expenditure deciles

3.2 Average household income by main income group and income deciles

3.3 Average household income by main income group and population group of household head

3.4 Average household income by main income group and province

3.5 Average household income by main income group and type of settlement

3.6 Percentage distribution of annual household income by main income group and expenditure deciles

3.7 Percentage distribution of annual household income by main income group

3.8 Percentage distribution of annual household income by main income group and income deciles

3.9 Percentage distribution of annual household income by main income group and population group of household head

3.10 Percentage distribution of annual household income by main income group and province

3.11 Percentage distribution of annual household income by main income group and type of settlement

3.12 Income by main income group 163

4. Ownership of assets $\quad 164$

4.1 Ownership of assets by sex of head of household 164

4.2 Ownership of assets by household income deciles 165

$\begin{array}{lll}4.3 & \text { Ownership of assets by household type of settlement } & 166\end{array}$

4.4 Ownership of assets by population group of household head 167

$\begin{array}{lll}4.5 & \text { Ownership of assets by province } & 168\end{array}$

$\begin{array}{lll}\text { 5. Household characteristics } & 169\end{array}$

5.1 Number of households by ownership of dwelling and income deciles 169

$5.2 \quad$ Number of households by main source of energy and income deciles 170

5.3 Number of households by main source of water and income deciles 171

5.4 Number of households by type of dwelling and income deciles 172

5.5 Number of households by sanitation facility and income deciles 173

$\begin{array}{lll}5.6 & \text { Number of households by type of refuse removal and income deciles } & 174\end{array}$ 


\section{Graphs}

Figure A1 - Proportion of total household expenditure on food and alcoholic beverages by population group of household head

Figure A2 - Proportion of total household expenditure on food and beverages by sex of household head

Figure A3 - Proportion of total household expenditure on food and alcoholic beverages by settlement type

Figure A4 - Proportion of total household expenditure on food and beverages by province

Figure B1 - Proportion of total household expenditure on clothing and footwear by population group of household head

Figure B2 - Proportion of total household expenditure on clothing and footwear by sex of household head

Figure B3 - Proportion of total household expenditure on clothing and footwear by settlement type

Figure B4 - Proportion of total household expenditure on clothing and footwear by province

Figure C1 - Proportion of total household expenditure on housing, water, electricity, gas and other fuels by population group of household head

Figure C2 - Proportion of total household expenditure on housing, water, electricity, gas and other fuels by sex of household head

Figure C3 - Proportion of total household expenditure on housing, water, electricity, gas, and other fuels by settlement type

Figure C4 - Proportion of total household expenditure on housing, water, electricity, gas and other fuels by province

Figure D1 - Proportion of total household expenditure on furnishings, household equipment and routine maintenance of the dwelling by population group of household head

Figure D2 - Proportion of total household expenditure on furnishings, household equipment and routine maintenance of the dwelling by sex of household head

Figure D3 - Proportion of total household expenditure on furnishings, household equipment and routine maintenance of the dwelling by settlement type

Figure D4 - Proportion of total household expenditure on furnishings, household equipment and routine maintenance of the dwelling by province

Figure E1 - Proportion of total household expenditure on health by population group of household head 
Figure E2 - Proportion of total household expenditure on health by sex of household head

Figure E3 - Proportion of total household expenditure on health by settlement type

Figure E4 - Proportion of total household expenditure on health by province

Figure F1 - Proportion of total household expenditure on transport by population group of household head

Figure F2 - Proportion of total household expenditure on transport by sex of household head

Figure F3 - Proportion of total household expenditure on transport by settlement type

Figure F4 - Proportion of total household expenditure on transport by province

Figure G1 - Proportion of total household expenditure on communication by population group of household head

Figure G2 - Proportion of total household expenditure on communication by sex of household head

Figure G3 - Proportion of total household expenditure on communication by settlement type

Figure G4 - Proportion of total household expenditure on communication by province

Figure H1 - Proportion of total household expenditure on recreation by population group of household head

Figure $\mathrm{H} 2$ - Proportion of total household expenditure on recreation and culture by sex of household head

Figure H3 - Proportion of total household expenditure on recreation and culture by settlement type

Figure H4 - Proportion of total household expenditure on recreation and culture by province

Figure I1 - Proportion of total household expenditure on education by population group of household head

Figure $12-\quad$ Proportion of total household expenditure on education by sex of household head

Figure I3 - Proportion of total household expenditure on education by settlement type

Figure $14-\quad$ Proportion of total household expenditure on education by province

Figure J1 - Proportion of total household expenditure on restaurants and hotels by population group of household head

Figure J2 - Proportion of total household expenditure on restaurants and hotels by sex of household head 
Figure J3 - Proportion of total household expenditure on restaurants and hotels by settlement type

Figure J4 - Proportion of total household expenditure on restaurants and hotels by province

Figure K1 - Proportion of total household expenditure on miscellaneous goods and services by population group of household head

Figure K2 - Proportion of total household expenditure on miscellaneous goods and services by sex of household head

Figure K3 - Proportion of total household expenditure on miscellaneous goods and services by settlement type

Figure K4 - Proportion of total household expenditure on miscellaneous goods and services by province 


\section{Introduction}

This report presents the results of the Income and Expenditure Survey conducted by Statistics South Africa (Stats SA) between September 2005 and August 2006 (IES 2005/2006). The survey was designed to collect information on items and services acquired by South African households, various sources of income acquired by participating households (monetary or in-kind) and details as to how they spent this income (on expenditure, remittances, etc.). This was accomplished by collecting details of all expenditure by a participating household and all acquisitions of goods and services for the household's own consumption within a given reference period. Studies of this nature play an important role in evaluating changes in consumption patterns, levels of income and income distribution. The results of the survey serve as an input into identifying the goods and services that should be included in the Consumer Price Index (CPI) basket of goods and services.

The information presented in this report was collected from a sample of 3000 primary sampling units (PSUs) obtained from Statistics South Africa's Master Sample. Eight dwelling units were selected from each PSU, i.e. 24000 dwelling units were sampled for participation. The sample was evenly spread over 12 survey periods of one month each, while keeping it nationally representative in each quarter.

\subsection{Background of the survey}

The IES 2005/2006 based on the diary method was the first of its kind to be conducted by Stats SA. Previously IESs were conducted by Stats SA every five years using the recall method. In the recall method a single questionnaire was administered to a household at a selected dwelling unit in the sample. The responding households were required to recall expenditure on all non-durable goods purchased during the month prior to the survey. They were also, in the case of durable and semi-durable goods, required to recall purchases of such goods for the 12 months prior to the survey. The previous IESs also collected information on various sources of income (monetary or in-kind) acquired by households and details about how they disposed of such income (expenditure on goods and services, remittances, etc.). The whole survey was conducted during a period of four weeks.

In line with best international practices, Stats SA decided to change the survey methodology from the recall method to a combination of the recall and the diary methods. Therefore, unlike the previous series of IESs conducted by Stats SA, the IES 2005/2006 was conducted using a combination of the diary and recall methods. This was accomplished with a fieldworker administering a main questionnaire to a selected household over five separate visits. The main questionnaire was divided into five separate interview modules, each covering different topics. One interview module was conducted per visit. In this main questionnaire, households were required to account for all acquisitions of durable and semi-durable goods and services over the 11 months prior to the survey.

Information was also collected regarding income acquired by different members of the household — both during the survey month and during the 11 months prior to the survey.

During the four weeks of the survey month, households were also given diaries and were required to record their daily acquisitions in a diary on a daily basis. In the case of households not being able to complete the diaries, the fieldworker visited them more often in order to assist with the completion of the diaries. The diaries were collected on a weekly basis for a period of a month. The purpose of the diary was to try to minimise or eliminate the recall problem over the four weeks of the survey month so that the information collected was as close as possible to the period of transaction. 
This first diary-based IES was conducted over a period of a year, between September 2005 and August 2006, with each selected household participating for one month and new sub samples of households starting every month. The general approach used to collect information on household consumption expenditure during this survey was that of acquisition. The acquisition approach takes into account the total value of all goods and services acquired, whether consumed or not, during a given period, whether or not they were wholly or partly paid for during the period of collection.

Table A below provides a summary of the main differences between the IES of 2000 (IES 2000) and IES 2005/2006.

Table A - Main differences between IES 2000 and IES 2005/2006

\begin{tabular}{|c|c|c|c|}
\hline \multicolumn{2}{|c|}{ Distinguishing features } & IES 2000 & IES 2005/2006 \\
\hline \multicolumn{2}{|l|}{ Sample size } & 30000 dwelling units & 24000 dwelling units \\
\hline \multicolumn{2}{|l|}{ Methodology } & Recall & Diary and recall \\
\hline \multicolumn{2}{|c|}{ Main questionnaire } & $\begin{array}{l}\text { One questionnaire (one } \\
\text { interview) }\end{array}$ & $\begin{array}{l}\text { One questionnaire (five } \\
\text { interviews) }\end{array}$ \\
\hline \multicolumn{2}{|l|}{ Diaries } & None & Four weekly diaries \\
\hline \multirow{3}{*}{$\begin{array}{l}\text { Expenditure } \\
\text { data } \\
\text { collection } \\
\text { approach }\end{array}$} & Goods & Payment approach & Acquisition approach \\
\hline & Services & Payment approach & Payment approach \\
\hline & $\begin{array}{l}\text { Own } \\
\text { production }\end{array}$ & Consumption approach & Consumption approach \\
\hline \multicolumn{2}{|l|}{ Survey period } & $\begin{array}{l}\text { Five weeks } \\
\text { Mainly October } 2000\end{array}$ & $\begin{array}{l}\text { One year } \\
\text { September } 2005 \text { to August } \\
2006\end{array}$ \\
\hline \multicolumn{2}{|c|}{$\begin{array}{l}\text { Reference period: Food } \\
\text { expenditure }\end{array}$} & September 2000 & $\begin{array}{l}\text { September } 2005 \text { to August } \\
2006\end{array}$ \\
\hline \multicolumn{2}{|c|}{ Visits per household } & One & Minimum six \\
\hline \multicolumn{2}{|c|}{$\begin{array}{l}\text { Classification of expenditure } \\
\text { items }\end{array}$} & $\begin{array}{l}\text { Standard Trade } \\
\text { Classification }\end{array}$ & $\begin{array}{l}\text { Classification of Individual } \\
\text { Consumption According to } \\
\text { Purpose (COICOP) }\end{array}$ \\
\hline
\end{tabular}




\section{Key findings}

The results of the Income and Expenditure Survey 2005/2006 show that the total annual household consumption expenditure during the survey year is estimated to be approximately R700 billion. On average, the estimated total household consumption expenditure per household in South Africa was R56 152. The main components of household consumption expenditure were: housing, water, electricity, gas and other fuels; transport; and food and non-alcoholic beverages.

Table B - Total and average household consumption expenditure by main expenditure group and income

\begin{tabular}{|l|r|r|r|}
\hline \multirow{2}{*}{ Main expenditure group and income } & \multicolumn{2}{|c|}{ Rand } & $\begin{array}{r}\text { Percentage } \\
\text { contribution }\end{array}$ \\
\cline { 2 - 4 } & Millions & Average & \\
Food and non-alcoholic beverages & 100971 & 8105 & 14,4 \\
Alcoholic beverages and tobacco & 8065 & 647 & 1,2 \\
Clothing and footwear & 34639 & 2781 & 5,0 \\
Housing, water, electricity, gas and other fuels & 165003 & 13245 & 23,6 \\
Furnishings, household equipment and routine & 48181 & 3868 & 6,9 \\
maintenance of the dwelling & 11620 & 933 & 1,7 \\
Health & 139278 & 11180 & 19,9 \\
Transport & 24534 & 1969 & 3,5 \\
Communication & 32160 & 2582 & 4,6 \\
Recreation and culture & 16894 & 1356 & 2,4 \\
Education & 15354 & 1232 & 2,2 \\
Restaurants and hotels & 100676 & 8081 & 14,4 \\
Miscellaneous goods and services & 2144 & 172 & 0,3 \\
Other unclassified expenses & $\mathbf{6 9 9} \mathbf{5 1 8}$ & $\mathbf{5 6} \mathbf{1 5 2}$ & $\mathbf{1 0 0 , 0}$ \\
Total consumption expenditure & $\mathbf{1 9 2 9 5}$ & $\mathbf{1 5 4 9}$ & $\mathbf{1 0 0 , 0}$ \\
Consumption-in-kind & $\mathbf{9 2 9} \mathbf{1 9 4}$ & $\mathbf{7 4 5 8 9}$ & $\mathbf{1 0 0 , 0}$ \\
Income & $\mathbf{1 9 2 9 5}$ & $\mathbf{1 5 4 9}$ & $\mathbf{1 0 0 , 0}$ \\
Income-in-kind & & & \\
\hline
\end{tabular}

Table B above shows that housing, water, electricity, gas and other fuels was the largest household consumption expenditure group in South Africa. The group contributed 23,6\% to the total household consumption expenditure. On average, each South African household is estimated to have spent approximately R13 245 on housing, water, electricity, gas and other fuels during the survey year.

The second largest contributor to consumption expenditure was transport. It is estimated that transport contributed $19,9 \%$ to the total household consumption expenditure during the survey year. This means that approximately one in every five rand spent by South African households on consumption expenditure was on transport. On average, a typical household spent approximately R11 180 on transport during the survey year. 
Table B also shows that food and non-alcoholic beverages contributed $14,4 \%$ to the total household consumption expenditure. On average, R8 105 was spent by each South African household on food and non-alcoholic beverages. This was the third largest expenditure group in the country during the $2005 / 2006$ survey period.

Miscellaneous goods and services weighed in at $14,4 \%$ of the total annual household consumption expenditure. The largest component of this main group was expenditure on insurance (including medical aid contributions).

Furnishings, household equipment and routine maintenance of the dwelling was responsible for $6,9 \%$ of the total household consumption expenditure. From the results of the IES 2005/2006 it is estimated that on average, a South African household spent R3 868 on this main expenditure group during the survey year.

Clothing and footwear contributed $5,0 \%$ to the total annual household consumption expenditure while recreation and culture was responsible for $4,6 \%$ of the total annual household consumption expenditure. On average, each South African household spent approximately R2 781 on clothing and footwear and R2 582 on recreation and culture during the survey year.

Communication contributed $3,5 \%$ to total household consumption expenditure, education contributed $2,4 \%$, and restaurants and hotels contributed 2,2\%; while $1,7 \%$ of total annual household consumption expenditure went to health (excluding medical aid, which is classified as insurance), and 1,2\% went to alcoholic beverages and tobacco.

Total household consumption-in-kind was estimated to be approximately R19,3 billion. On average, each South African household is estimated to have consumed goods and services worth R1 549 which it did not directly pay for. Such goods and services exclude gifts received from non-household members.

From the results of the survey it is estimated that total household income during the survey year was approximately R929,2 billion. The average annual income of a South African household was estimated at R74 589. 


\section{Summary of the findings}

\subsection{Household consumption expenditure}

Figure 1 - Percentage distribution of total annual household consumption expenditure in South Africa by main expenditure group

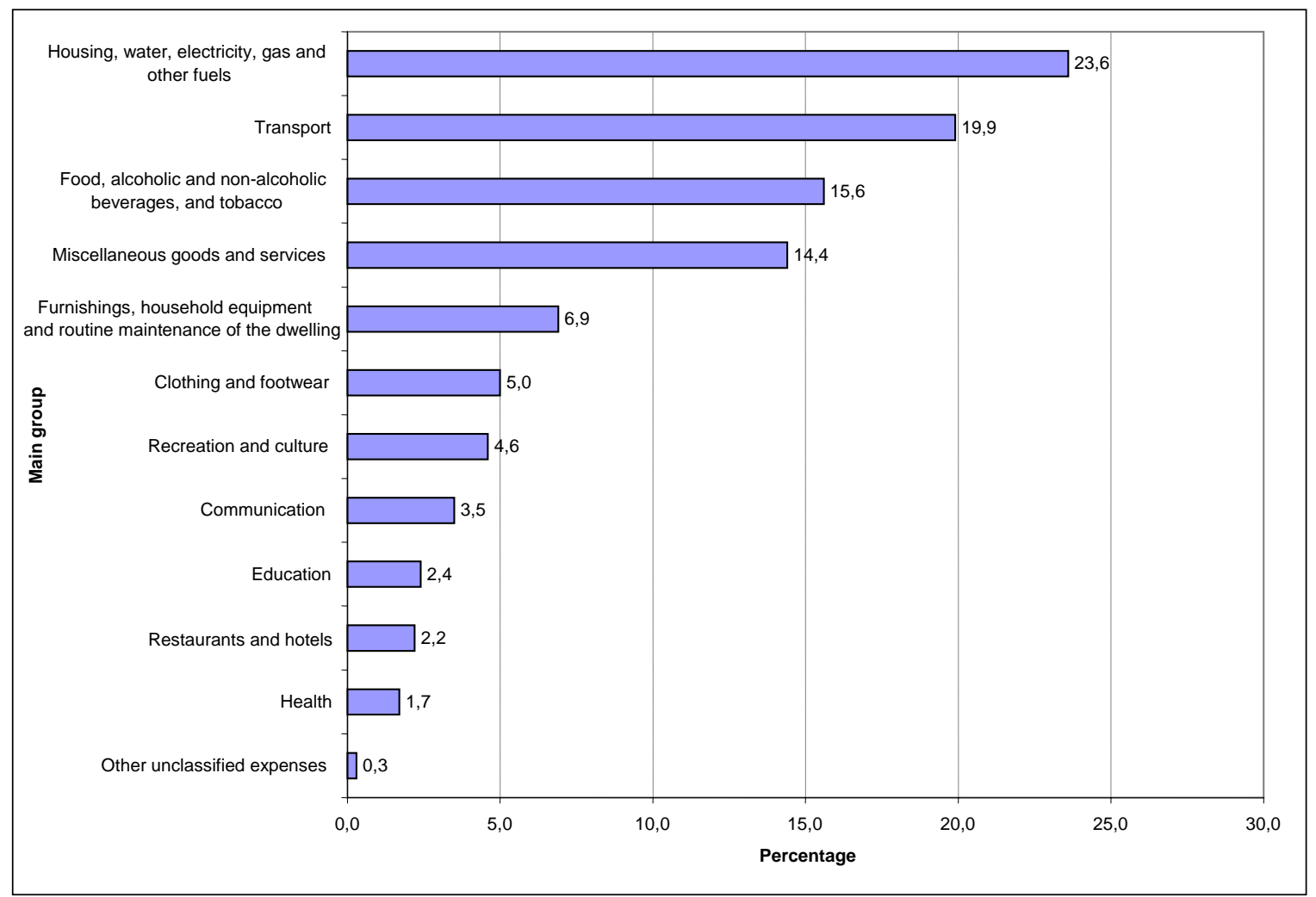

Total expenditure on housing, water, electricity, gas and other fuels was the largest contributor to total annual household consumption expenditure in the country. This group was responsible for $23,6 \%$ of the total household consumption expenditure nationally. Housing includes the annual rental value of the dwelling unit or the annual estimated rental value of the dwelling unit if the dwelling unit was rented free in the case of rented dwelling units or $7 \%$ of the value of the dwelling unit, in the case of owner-occupied dwelling units. Housing excludes mortgage bonds, interest on mortgages and estimated rental value for owneroccupied dwelling units.

Figure 1 above shows that one in every five rand $(19,9 \%)$ was spent on transport, while expenditure on food, alcoholic and non-alcoholic beverages, and tobacco was 15,6\% of the total household consumption expenditure. The miscellaneous goods and services expenditure group was responsible for $14,4 \%$ of the total household consumption expenditure. This group includes, among other things, personal care and insurance, with the latter as the main component.

Furnishings, household equipment and routine maintenance of the dwelling was $6,9 \%$ of the total household consumption expenditure, while one in every twenty rand $(5,0 \%)$ spent by a South African household went towards clothing and footwear. Households spent 4,6\% of their budgets on recreation and culture, and 3,5\% towards communication. 
Figure 1 above also shows that only 2,4\% of the total household consumption expenditure in South Africa was on education, while only $1,7 \%$ was on health (this expenditure group excludes medical aid premiums, which are classified as insurance). A larger proportion of the cost for medical services was covered through medical insurance and public funding. South African households in general spent $2,2 \%$ of their budget on restaurants and hotels, which includes catering and accommodation services.

Figure 2 - Percentage distribution of annual household consumption expenditure on broad expenditure groups by population group of household head

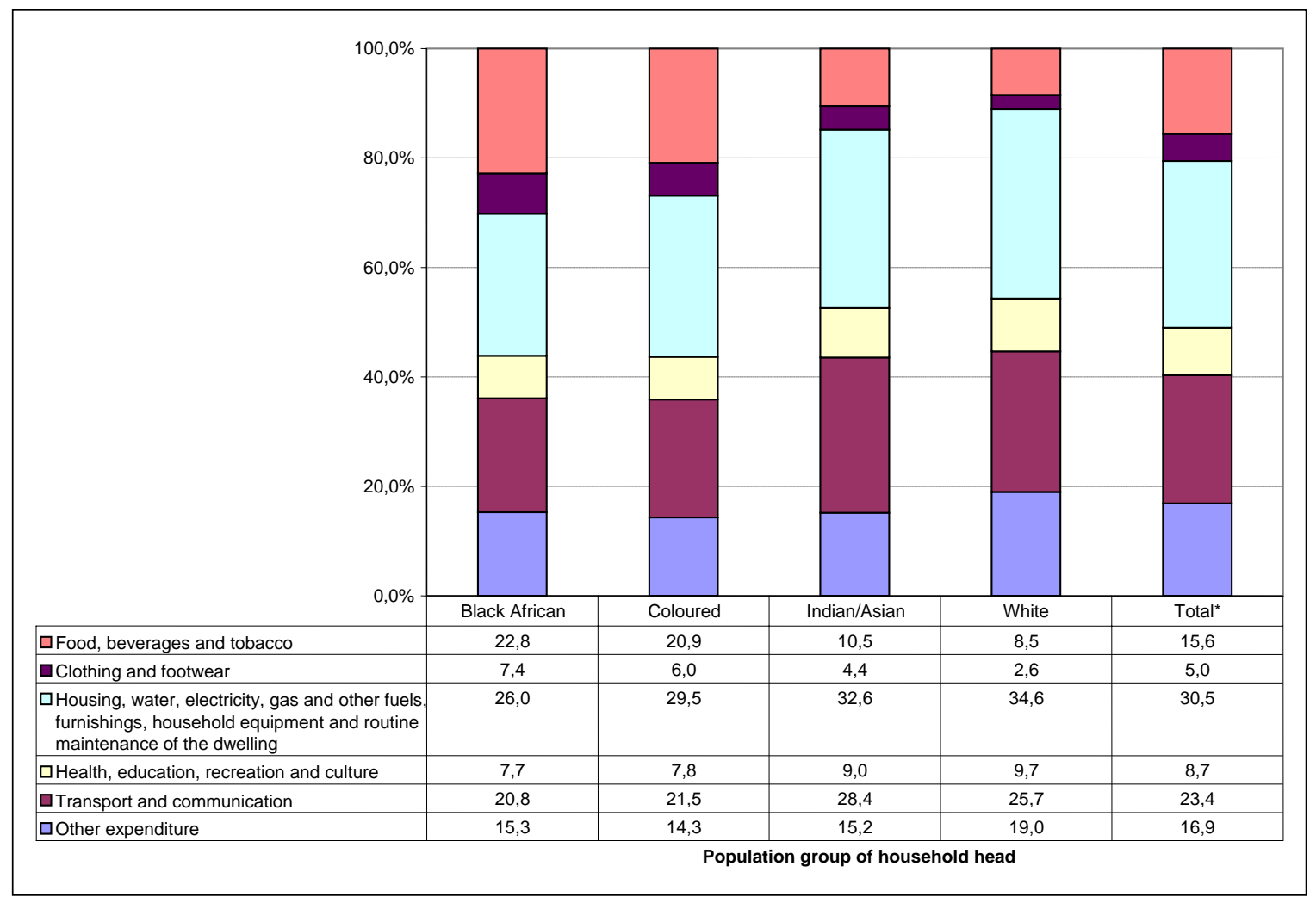

Total$^{\star}$ includes unspecified population group of household head

Figure 2 above shows that at least one in every five rand spent by an average South African household was on food and clothing. Expenditure on food, beverages and tobacco and clothing and footwear together contributed $20,6 \%$ to the total annual consumption expenditure of South African households. As a population group, black African households spent a much larger proportion on food than the other population groups. Almost one in every three rand $(30,2 \%)$ of the total household consumption expenditure for black African households was spent on food, beverages, clothing and footwear; while white households spent approximately one in every ten rand $(11,1 \%)$ of their consumption budget on the same items.

Among black African households $26,0 \%$ of the total household consumption expenditure was on housing, water, electricity, gas and other fuels; and furnishings, household equipment and routine maintenance of the dwelling. This was followed by food, beverages and tobacco at $22,8 \%$ and transport and communication at $20,8 \%$. However, food, beverages and tobacco accounted for just $8,5 \%$ of the total consumption expenditure of white households.

Black African households spent $7,4 \%$ of their total consumption expenditure on clothing and footwear, while white households devoted only $2,6 \%$ of their total consumption expenditure to clothing and footwear. 
Figure 3 - Average annual household consumption expenditure of South African households by population group of household head

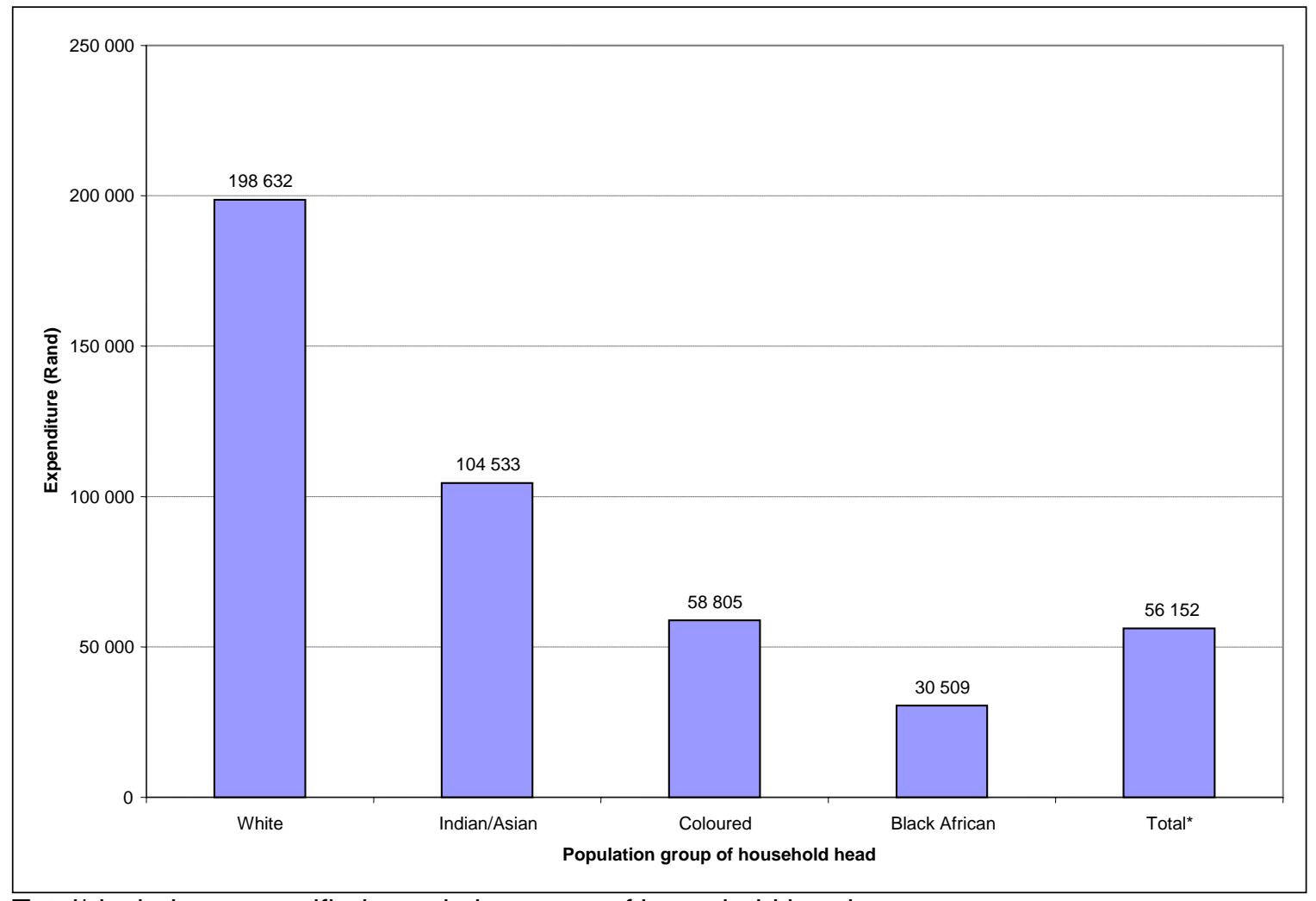

Total* includes unspecified population group of household head

On average, a typical South African household spent approximately R56 151 per annum. This average includes households where the population group of the household head was not specified.

Figure 3 above shows that the average annual household consumption expenditure by white South African households was R198 632. At the other end of the scale is the black African household which on average spent R30 509 per annum. Coloured households spent on average R58 805, while Indian/Asian households spent R104 533 per annum. 
Figure 4 - Distribution of South African households by expenditure quintiles and population group of household head

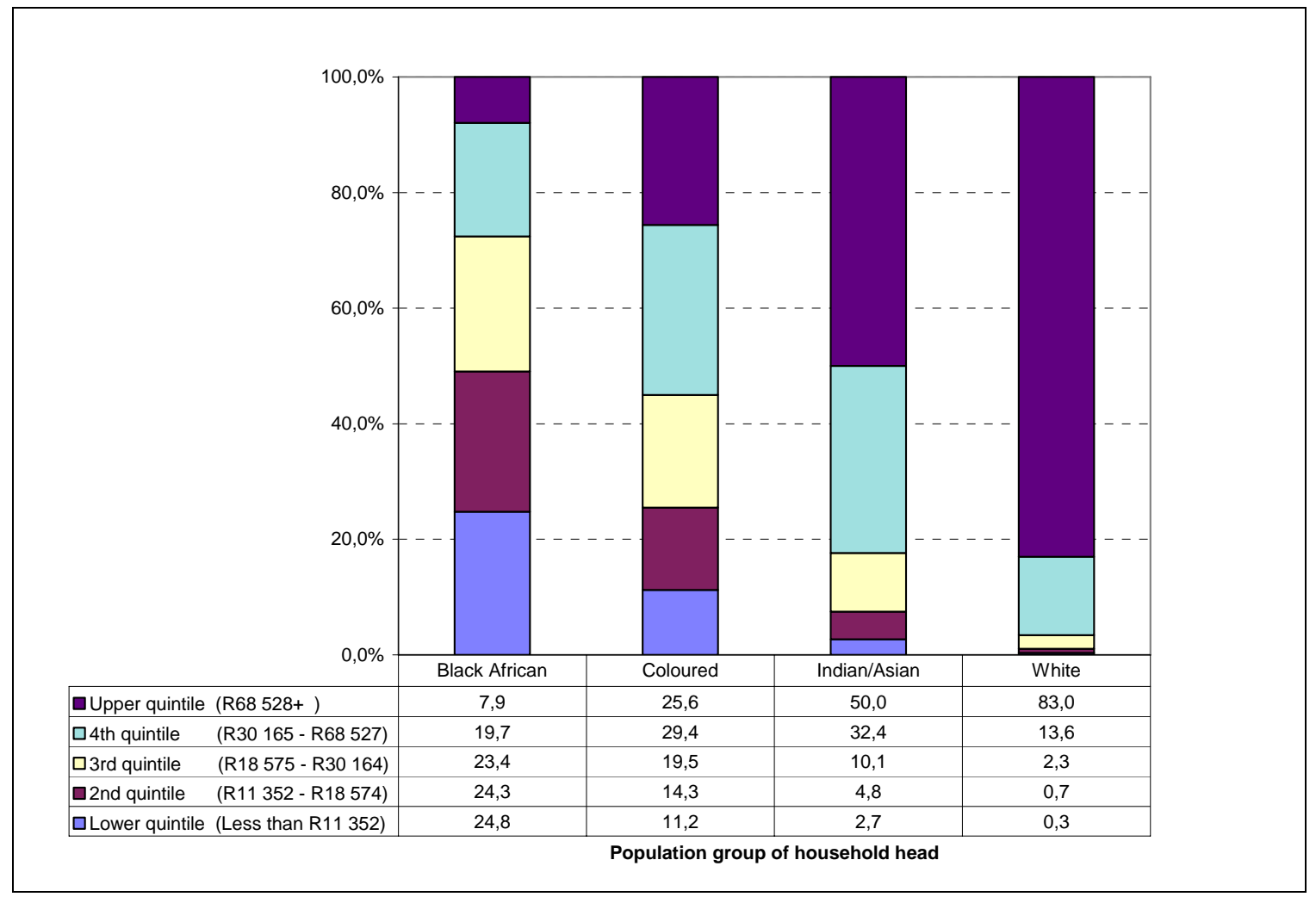

Figure 4 above looks at the distribution of South African households according to expenditure quintiles within each population group. The graph highlights differences in the spending patterns of the four population groups.

Figure 4 shows that 7,9\% of black African households fell within the upper expenditure quintile, and $49,1 \%$ black African households fell within the lowest two expenditure quintiles combined.

Half (50\%) of Indian/Asian households fell in the upper expenditure quintile, whereas at least four in every five Indian/Asian households $(82,4 \%)$ fell above the middle expenditure quintile.

Among all population groups, coloured households were most evenly distributed within expenditure quintiles. However, $55 \%$ of coloured households fell above while $25,5 \%$ fell below the middle expenditure quintile. At least one in every ten coloured households $(11,2 \%)$ fell within the lower expenditure quintile.

The results of the survey show that approximately four in every five white households $(83,0 \%)$ fell in the upper expenditure quintile. Only one in every hundred white households $(1,0 \%)$ fell within the lowest two expenditure quintiles combined. 


\subsection{Household income}

Figure 5 - Average annual income of South African households by population group of household head

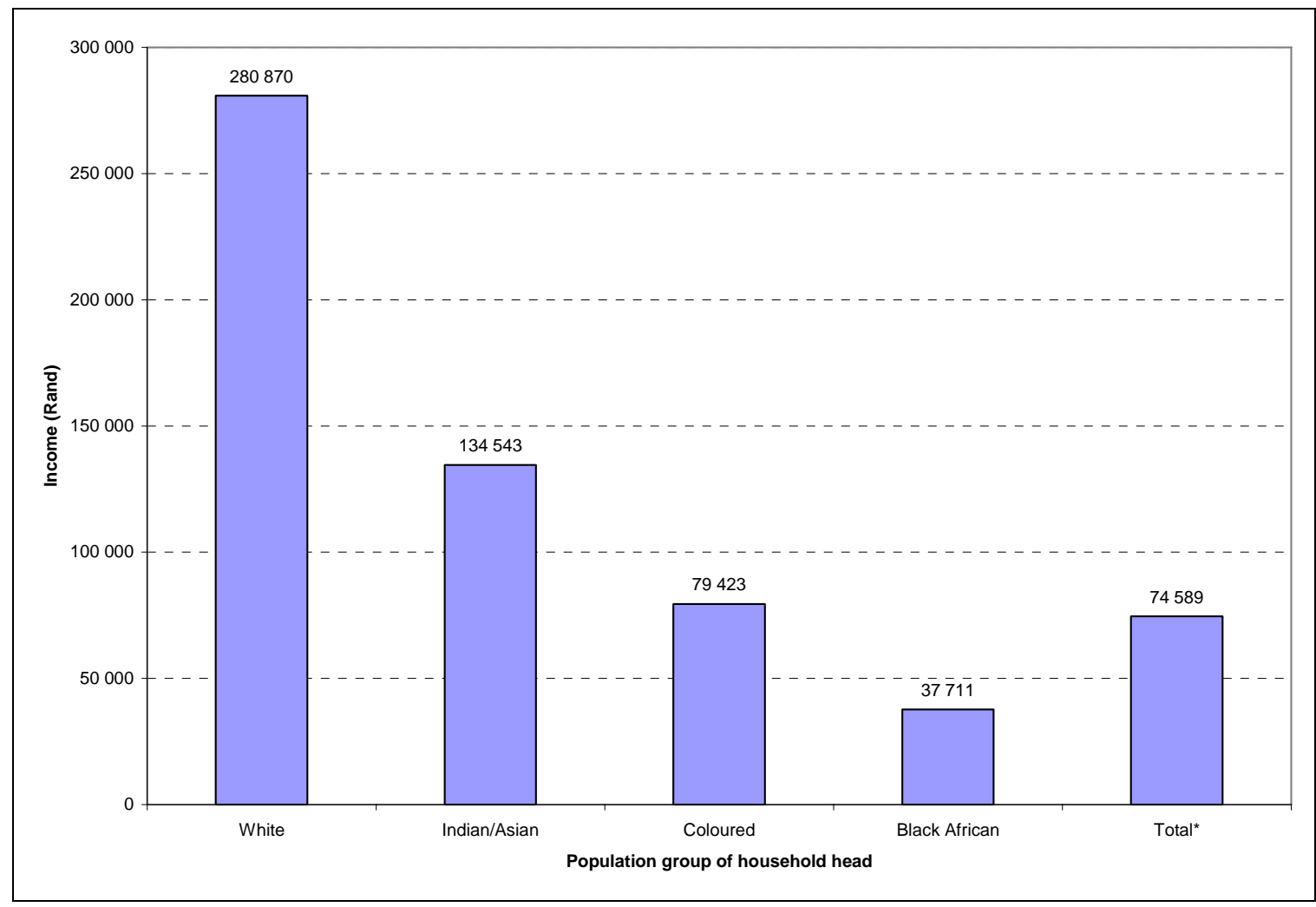

Total$^{\star}$ includes unspecified population group of household head

As Figure 5 above indicates, average annual household income in South Africa followed the same pattern as average annual household consumption expenditure by population group of the household head.

The IES 2005/2006 results indicate that the estimated average annual household income of a South African household was R74 589. This average includes households where the population group of the household head was not specified.

Figure 5 also shows that, whereas the estimated average annual household income for white households was R280 870, the average household income for black African households was estimated to be R37 711.

Between the two contrasting estimates of the black African and white households are the Indian/Asian and coloured average household incomes, estimated at R134 543 and R79 423, respectively. 
Figure 6 - Distribution of South African households by income quintiles and population group of household head

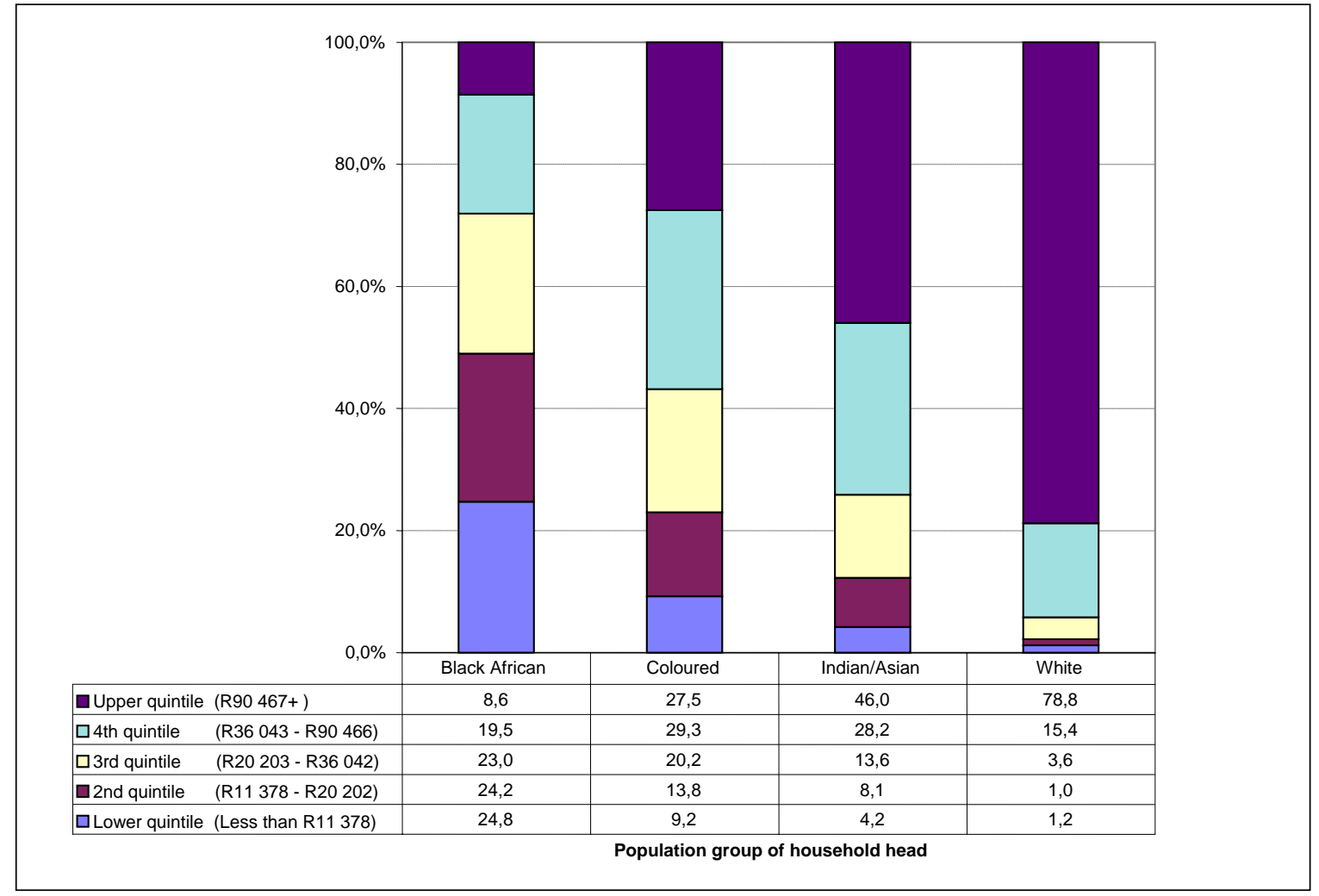

Figure 6 above shows that on average, less than one in every ten black African households $(8,6 \%)$ earned an annual income falling into the upper income quintile; and almost half $(49 \%)$ fell below the middle income quintile. On the other hand, almost four out of every five white households $(78,8 \%)$ earned an annual income falling within the upper income quintile.

Approximately one in every four black African households (24,8\%) earned an annual income falling within the lowest income quintile of the South African population. On the other hand, $1,2 \%$ white households earned an annual income falling within the lower income quintile. Figure 6 above also shows that $46,0 \%$ of the Indian/Asian households fell into the upper income quintile of the population.

For the coloured population, the proportion of households earning an annual income falling in the upper income quintile was $27,5 \%$. More than half $(56,8 \%)$ of coloured households earned an annual income falling above while just under one in every four $(23,0 \%)$ earned an annual income falling below the middle income quintile. 
Figure 7 - Distribution of annual household income by main income group and sex of household head

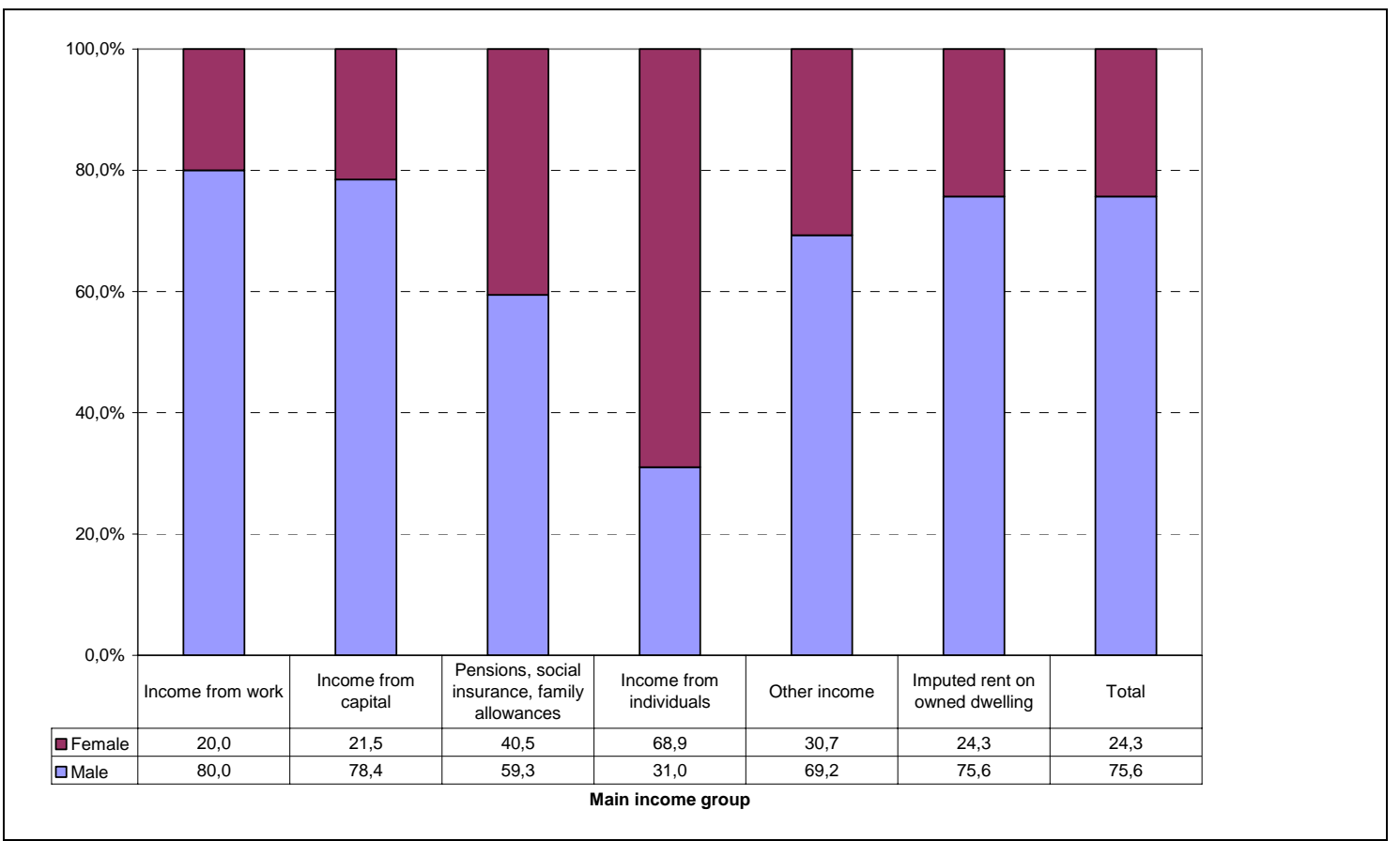

Figure 7 above shows that in general the majority of household income was earned by maleheaded households. The results of the IES 2005/2006 show that at least three quarters $(75,6 \%)$ of total household income was earned by male-headed households.

When the various sources of income are examined separately, it indicates that $80,0 \%$ of the total annual household income from work is earned by male-headed households. Maleheaded households also outperformed their female counterparts with regard to income from capital (78,4\%); pensions, social insurance and family allowances $(59,3 \%)$; other income not elsewhere classified $(69,2 \%)$; and income in the form of imputed rent on owned dwellings $(75,6 \%)$.

Figure 7 also shows that $78,4 \%$ of total annual household income earned from capital was earned by male-headed households, whereas $68,9 \%$ of income received from individuals was earned by female-headed households - mostly in the form of remittances. 
Figure 8 - Percentage distribution of annual household income by main income group and population group of household head

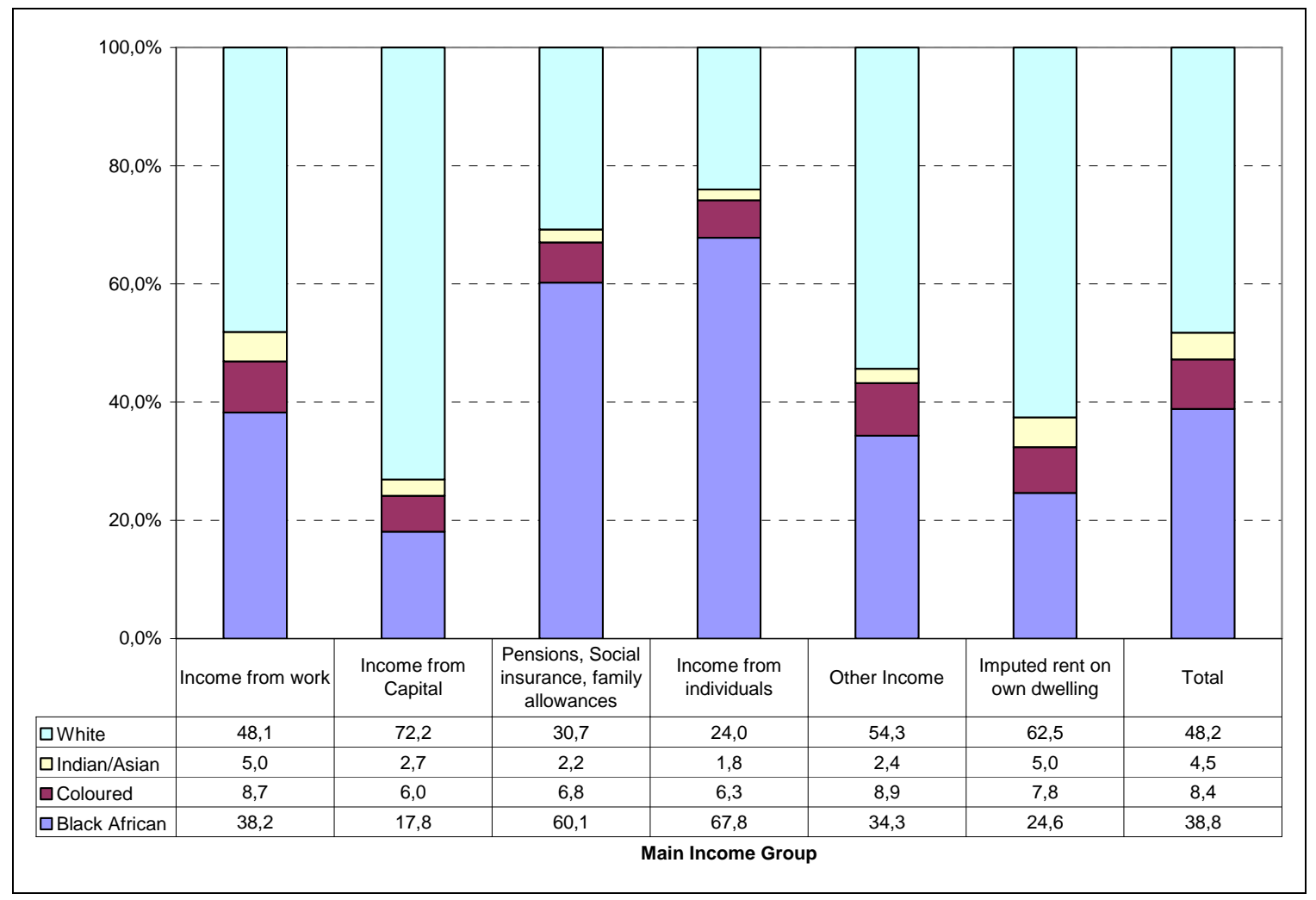

Figure 8 above shows that almost half $(48,2 \%)$ of the total household income was earned by white households. White households also received approximately $72,2 \%$ of the total household income from capital, 30,7\% of the income from pensions, social insurance and family allowances, $24,0 \%$ of the income from individuals, and $54,3 \%$ of other income not elsewhere classified. Almost two-thirds $(62,5 \%)$ of the imputed rent on own dwellings was also attributed to white households.

Black African households, however, earned most of the income from individuals and from pensions, social insurance and family allowances. Approximately $67,8 \%$ of the income from individuals and $60,1 \%$ of the income from pensions, social insurance and family allowances was earned by black African households.

Approximately half $(48,1 \%)$ of all the income earned from work by South African households was earned by white households; $38,2 \%$ by black African households; $8,7 \%$ by coloured and $5,0 \%$ by Indian/Asian households. 


\section{Findings}

\subsection{Food, beverages and tobacco}

Expenditure on food, beverages and tobacco accounted for $15,6 \%$ of the total household consumption expenditure in South Africa in the IES 2005/2006. However, at population group level, expenditure on food, beverages and tobacco accounted for $22,8 \%$ of the total household consumption expenditure of black African households. The coloured households spent approximately one in every five rand $(20,9 \%)$ of its household consumption expenditure on food, beverages and tobacco, while Indian/Asian population spent approximately one in every ten rand $(10,5 \%)$ of their budget on the same items. Among white household, expenditure on food, beverages and tobacco represented $8,5 \%$ of their total consumption expenditure.

Figure 9 - Proportion of total household consumption expenditure attributed to food, beverages and tobacco by population group of household head

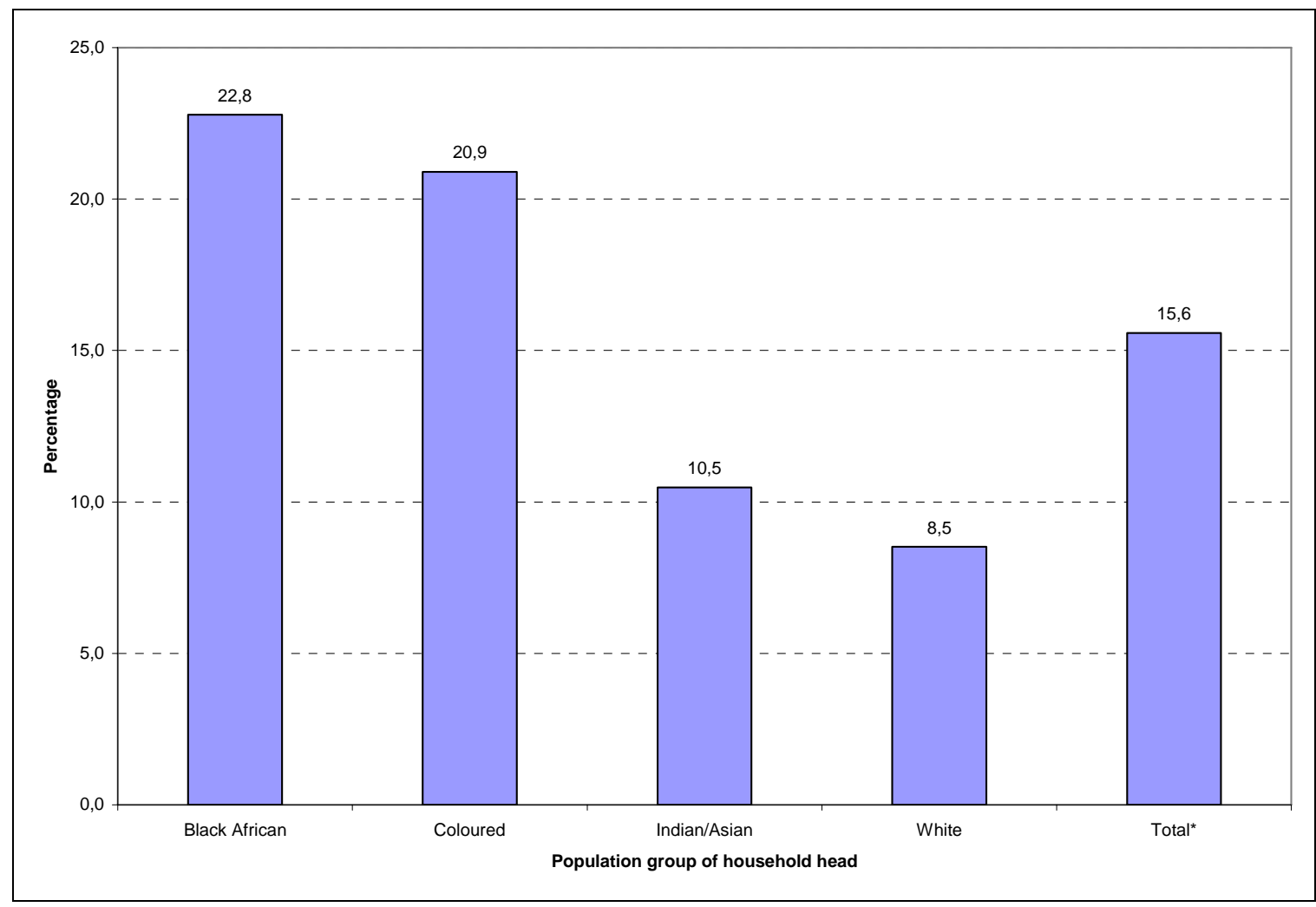

Total$^{\star}$ includes unspecified population group of household head

If alcoholic beverages and tobacco are excluded, approximately one in every four rand $(24,8 \%)$ spent by rural households was on food and non-alcoholic beverages, while in the urban areas this figure was $12,5 \%$. Of the nine provinces, households in Limpopo and Eastern Cape provinces spent the highest proportion of their household consumption expenditure on food and non-alcoholic beverages, i.e. $22,1 \%$ and $17,8 \%$, respectively.

Bread, cereal and meat were the major components of food expenditure, especially among black African households. Together, these components accounted for $10,9 \%$ of the total household consumption expenditure of black African households. 
Female-headed households allocated a higher proportion of their household budget to food. The results of the survey show that among female-headed households almost one in every five rand $(18,9 \%)$ spent by the households went towards food and non-alcoholic beverages. For male-headed households, the figure was much lower. Only $12,8 \%$ of the total consumption expenditure of male-headed households went towards food and non-alcoholic beverages.

\subsection{Clothing and footwear}

According to the IES 2005/2006, on average, a South African household spent 5,0\% of their consumption budget on clothing and footwear. Figure 10 below shows that the proportion on clothing and footwear was higher in the less urbanised provinces of Limpopo $(6,7 \%)$, Northern Cape and Free State (both 5,8\%), Eastern Cape (5,7\%), Mpumalanga and KwaZulu-Natal (both 5,6\%), than in the more urbanised provinces of Western Cape $(3,5 \%)$ and Gauteng $(4,7 \%)$. Generally, rural households spent $7,1 \%$ of their budget on clothing and footwear compared with $4,6 \%$ of the budget spent by urban households on similar items.

\section{Figure 10 - Proportion of total household consumption expenditure attributed to} clothing and footwear by province

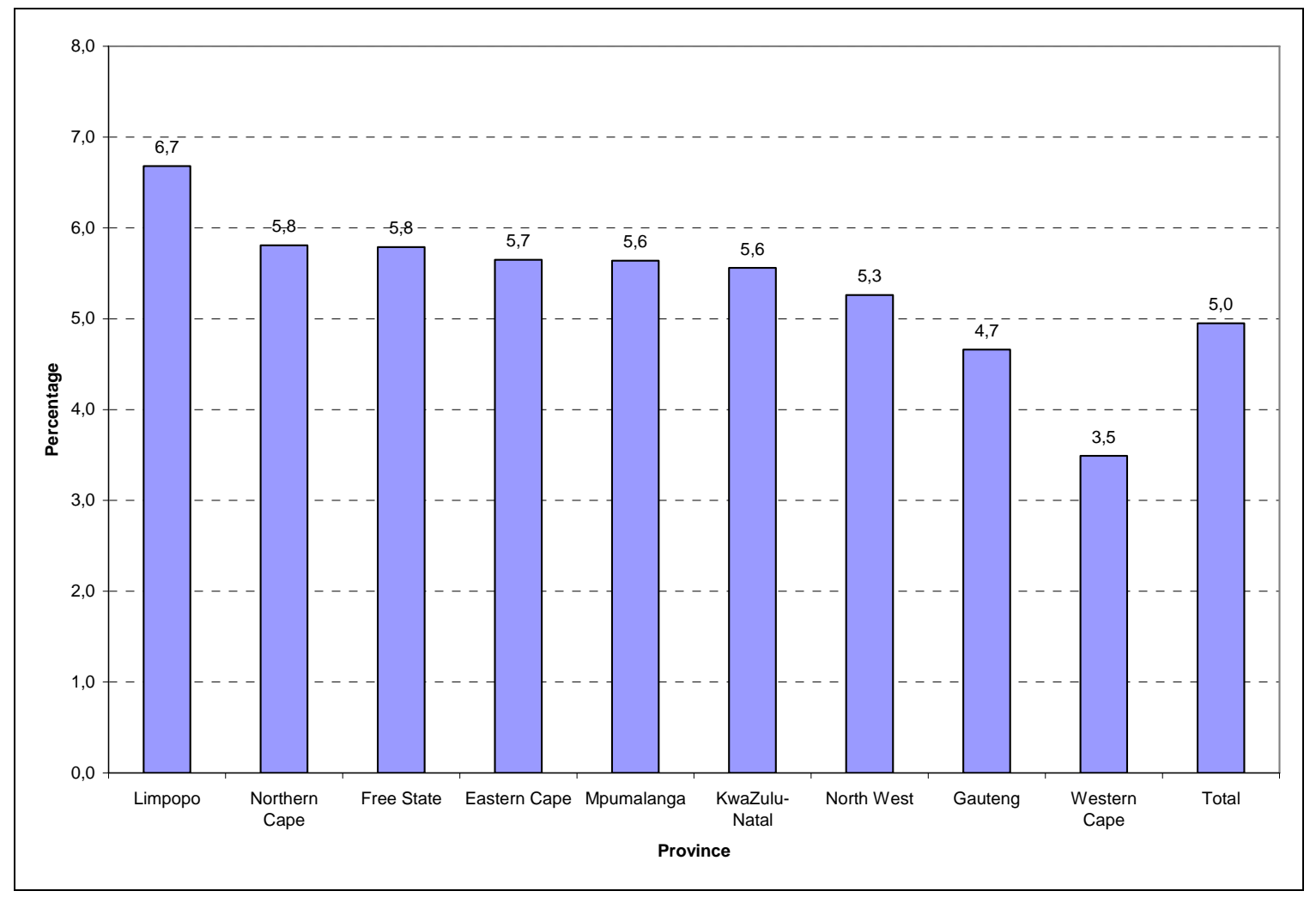

Black African households also spent a higher proportion of their budget on clothing and footwear $(7,4 \%)$ compared with the proportions spent by coloured, Indian/Asian and white households $(6,0 \%, 4,4 \%$ and $2,6 \%$, respectively).

Within the clothing and footwear group of expenditure items, the main component of expenditure was garments, which accounted for approximately $3,4 \%$ of the total household consumption expenditure, followed by shoes and other footwear (approximately 1,4\%). 


\subsection{Housing, water, electricity, gas and other fuels}

Housing, water, electricity, gas and other fuels was the single most important group of consumption expenditure for households in South Africa. Together, these items accounted for $23,6 \%$ of the total household consumption expenditure.

Figure 11 - Proportion of total household consumption expenditure attributed to housing, water, electricity, gas and other fuels by population group of household head

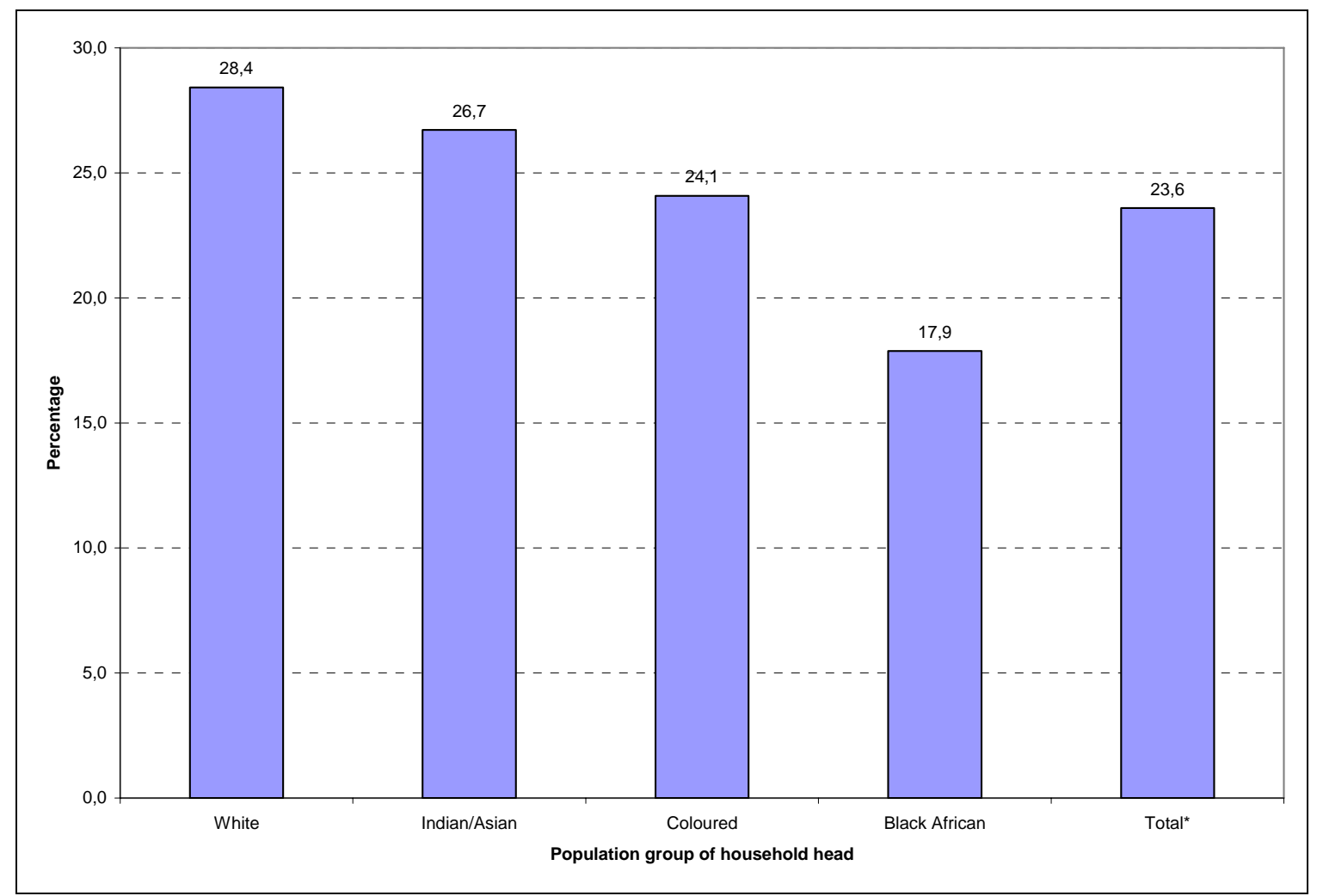

Total$^{\star}$ includes unspecified population group of household head

Figure 11 above shows that white households allocated a larger share $(28,4 \%)$ of their budget to housing, water, electricity, gas and other fuels, followed by Indian/Asian and coloured households, which allocated $26,7 \%$ and $24,1 \%$, respectively. Black African households spent a smaller percentage of their total budget on these services. Approximately one in every five rand $(17,9 \%)$ spent by black African households was on housing, water, electricity, gas and other fuels. 


\subsection{Furnishings, household equipment and routine maintenance of the dwelling}

Furnishings, household equipment and routine maintenance of the dwelling accounted for $6,9 \%$ of the household consumption expenditure in the country. The proportion spent by female-headed households $(7,6 \%)$ on this group of expenditure items was slightly higher than the proportion spent by male-headed households $(6,6 \%)$.

Figure 12 - Proportion of total household consumption expenditure attributed to furnishings, household equipment and routine maintenance of the dwelling by settlement type

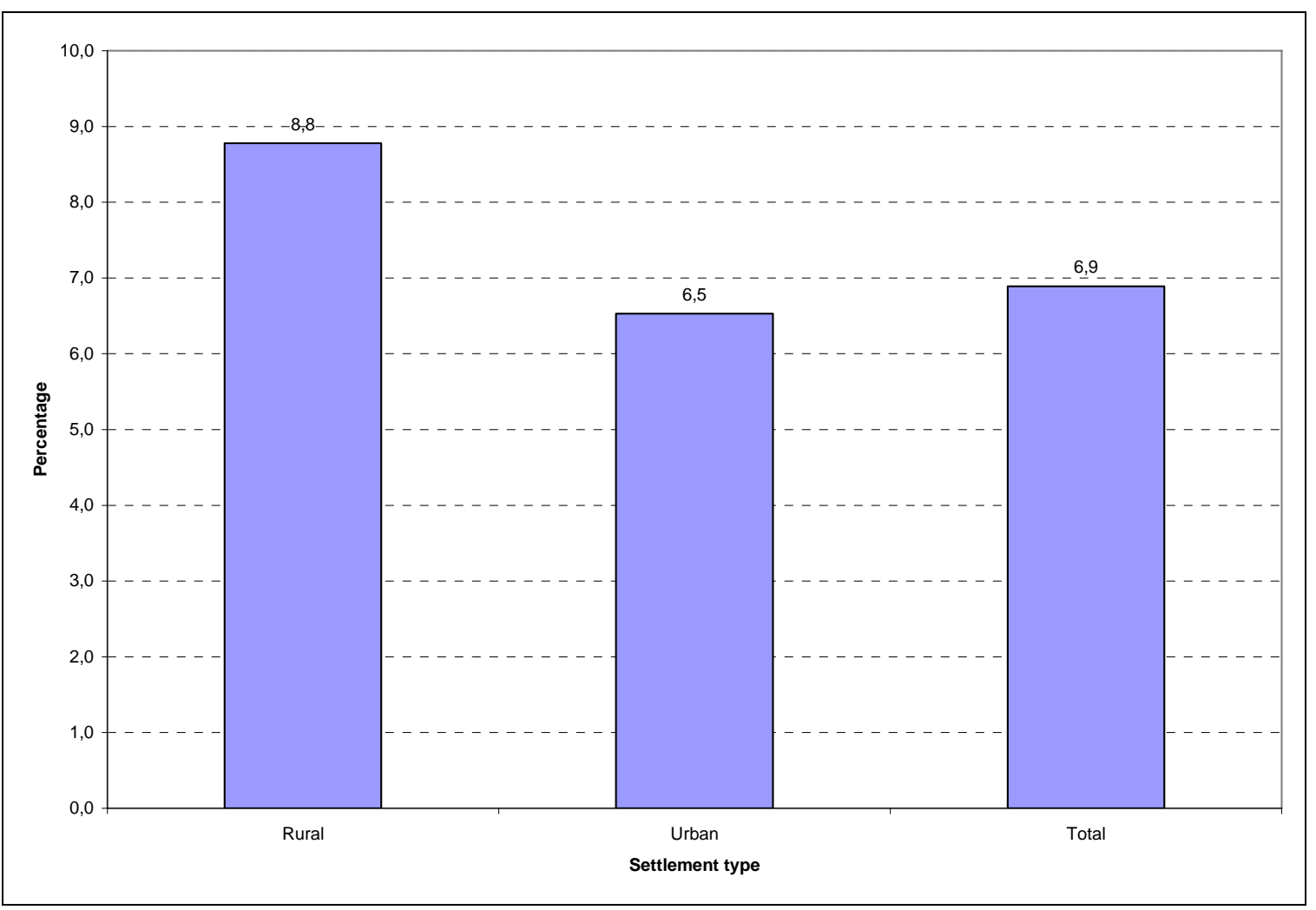

Figure 12 above indicates that the amount of money spent by rural households on furnishings, household equipment and routine maintenance of the dwelling represented a higher proportion $(8,8 \%)$ of their household consumption expenditure than was the case with urban households. Urban households spent $6,5 \%$ of their consumption expenditure on similar items. The same trend held for predominantly rural versus predominantly urban provinces. For example, while households in Limpopo allocated $8,8 \%$ of their consumption expenditure to household equipment. Similar items accounted for only 5,2\% of consumption expenditure in Western Cape.

The major components of expenditure on furnishings, household equipment and routine maintenance of the dwelling among white households were domestic services and household articles, while for black African households the main components were furniture, furnishings and household textiles. 


\subsection{Health}

Expenditure on health contributed $1,7 \%$ to household consumption expenditure in South Africa. Note, however, that this excludes health insurance or medical aid subscriptions (classified in the insurance section of the miscellaneous expenditure group). Health services are provided in the country by the private and public sectors.

Table C - Annual household consumption expenditure on private medical services in South Africa by population group of household head

\begin{tabular}{|l|r|r|r|r|r|}
\hline Expenditure item & $\begin{array}{r}\text { Black } \\
\text { African }\end{array}$ & Coloured & Indian/Asian & White & Total $^{\star}$ \\
\hline Pharmaceutical products & 33,4 & 40,3 & 38,2 & 34,5 & 34,6 \\
Other medical products & 1,3 & 1,5 & 1,5 & 1,0 & 1,1 \\
Therapeutic appliances & & & & & \\
and equipment & 1,6 & 3,8 & 4,1 & 3,5 & 2,8 \\
Medical services & 50,1 & 33,6 & 22,5 & 31,4 & 37,9 \\
Dental services & 2,4 & 3,0 & 4,4 & 8,6 & 5,9 \\
Paramedic services & 2,6 & 6,1 & 20,9 & 8,0 & 6,5 \\
Hospital services & 8,6 & 11,8 & 8,4 & 13,1 & 11,2 \\
\hline Total & $\mathbf{1 0 0 , 0}$ & $\mathbf{1 0 0 , 0}$ & $\mathbf{1 0 0 , 0}$ & $\mathbf{1 0 0 , 0}$ & $\mathbf{1 0 0 , 0}$ \\
\hline
\end{tabular}

Total$^{\star}$ includes unspecified population group of household head

Table $C$ above shows that pharmaceutical products and medical services were the major components of private health expenditure among South African households. Approximately $37,9 \%$ of the household consumption expenditure through private health services was spent on medical services such as consultations with general practitioners, specialists and traditional healers. This was closely followed by expenditure on pharmaceutical products at $34,6 \%$.

Table $\mathrm{C}$ above also shows that the percentage distribution of household consumption expenditure on private health services differed considerably from one population group to another. Unlike black African households, the coloured, Indian/Asian and white households spent a larger proportion of their private health budget on pharmaceutical products than on medical services.

Also noteworthy is the high proportion of private health household consumption expenditure by Indian/Asian households on paramedic services. Over one in every five rand (20,9\%) spent by Indian/Asian households on private medical services went towards paramedic services. 


\subsection{Transport}

Figure 13 below shows that approximately one in every five rand (19,9\%) of household consumption expenditure went towards transport. The share allocated to transport among male-headed households $(21,3 \%)$ was larger than the corresponding figure for femaleheaded households $(16,3 \%)$.

Figure 13 - Proportion of total household consumption expenditure attributed to transport by population group of household head

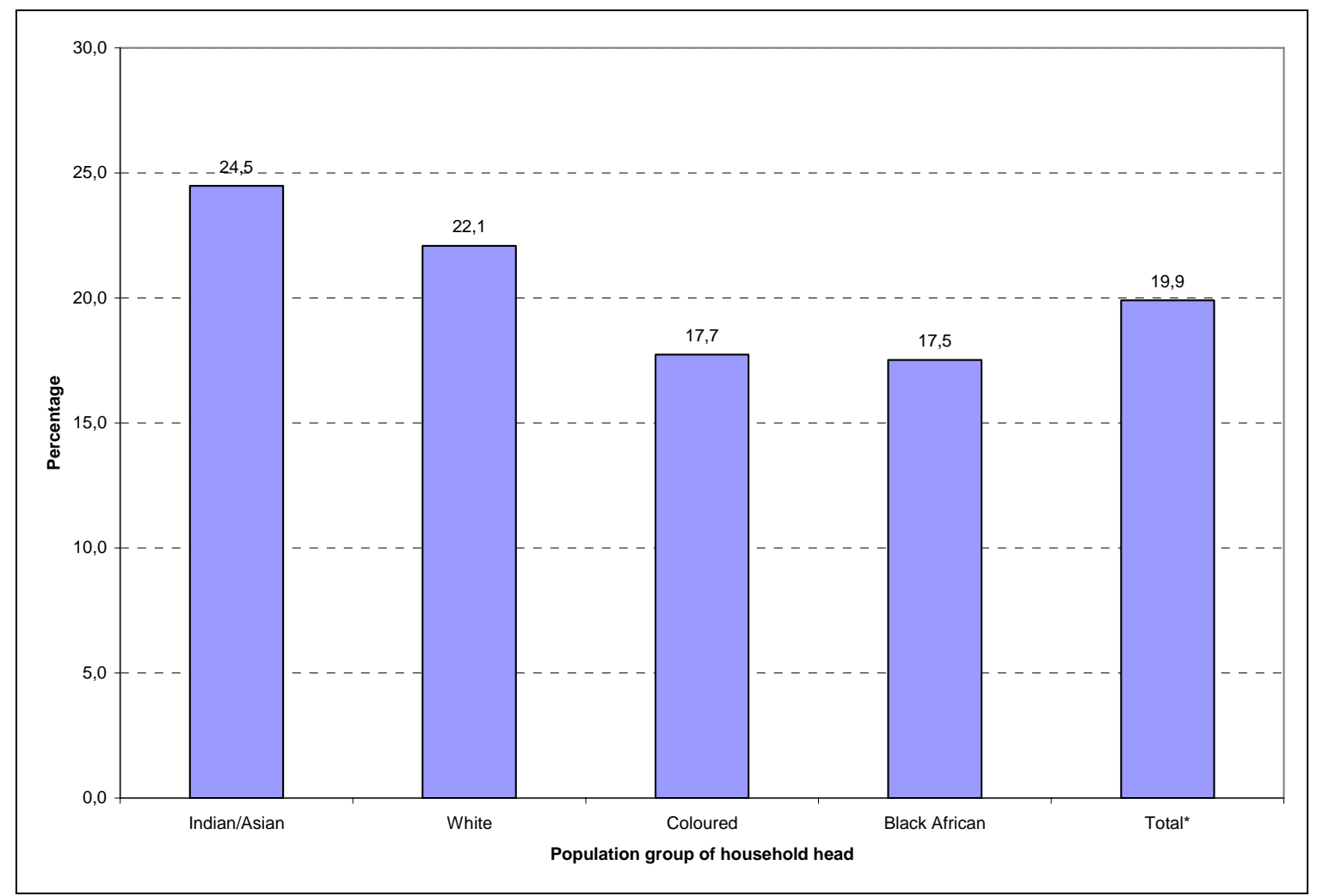

Total* includes unspecified population group of household head

The results of the survey indicate that the proportion of household income spent on transport increased with household income. Households that fell within lower income deciles allocated a smaller proportion of their consumption expenditure towards transport than households in the upper income deciles. Specifically, households in the lower income deciles spent approximately one-tenth of their consumption expenditure on transport while households in the upper income deciles allocated almost one quarter of their total household budget to transport.

Expenditure patterns on transport differ significantly between rural to urban areas. Among urban households more than one in every five rand $(20,8 \%)$ went towards transport, whereas the corresponding figure for rural areas was $15,3 \%$.

The proportion of household consumption expenditure attributed to transport among Indian/Asian households was $24,5 \%$. This was the highest among all population groups, followed by white $(22,1 \%)$, coloured $(17,7 \%)$ and black African $(17,5 \%)$ households. A major component of transport expenditure was the purchase of vehicles (new and used), which alone was responsible for $11,5 \%$ of the country's household consumption expenditure. 


\subsection{Communication}

Nationally, 3,5\% of household consumption expenditure was attributed to communication, the largest component of which was telephone and telefax services. There was little disparity between provinces regarding communication's share of consumption expenditure. Limpopo had the lowest at 3,1\% and KwaZulu-Natal at 4,0\%.

There was even less disparity between population groups. Black African households spent $3,3 \%$ of their consumption expenditure on communication (the lowest expenditure out of the four population groups) compared with 3,9\% for Indian/Asian households (the highest).

Figure 14 - Proportion of total household consumption expenditure attributed to communication by settlement type

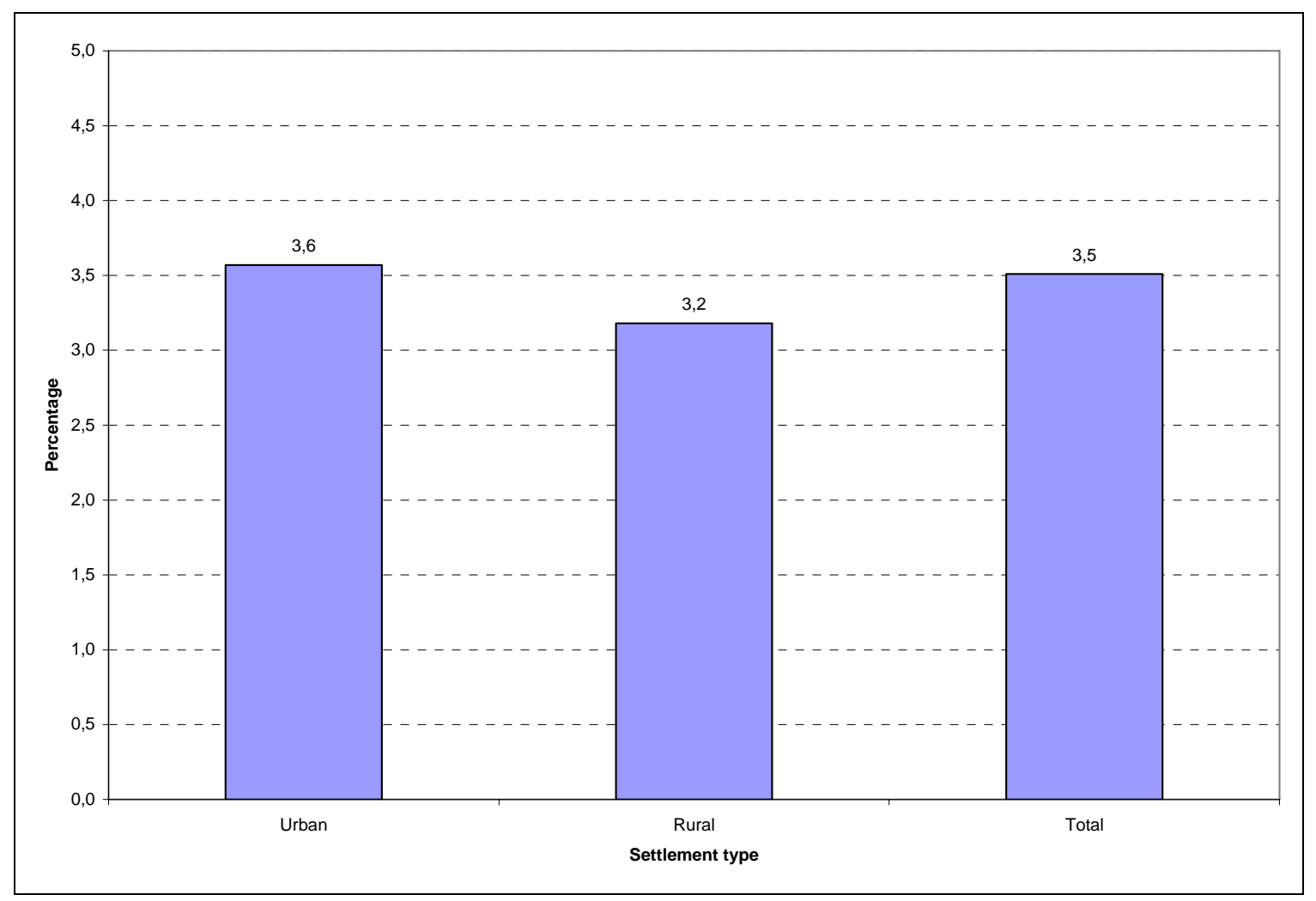

Figure 14 shows that urban households allocated a higher share of their household consumption expenditure to communication $(3,6 \%)$ than rural households $(3,2 \%)$. 


\subsection{Recreation and culture}

Figure 15 below shows that recreation and culture accounted for $4,6 \%$ of the total household consumption expenditure nationally. The survey results show that there was a higher allocation of household consumption expenditure towards recreation and culture in the predominantly urban provinces $(5,3 \%$ and $4,9 \%$ of household consumption expenditure in Western Cape and Gauteng, respectively) than in the predominantly rural provinces (3,4\% and 3,6\% in Eastern Cape and Limpopo, respectively).

Figure 15 - Proportion of total household consumption expenditure attributed to expenditure on recreation and culture by province

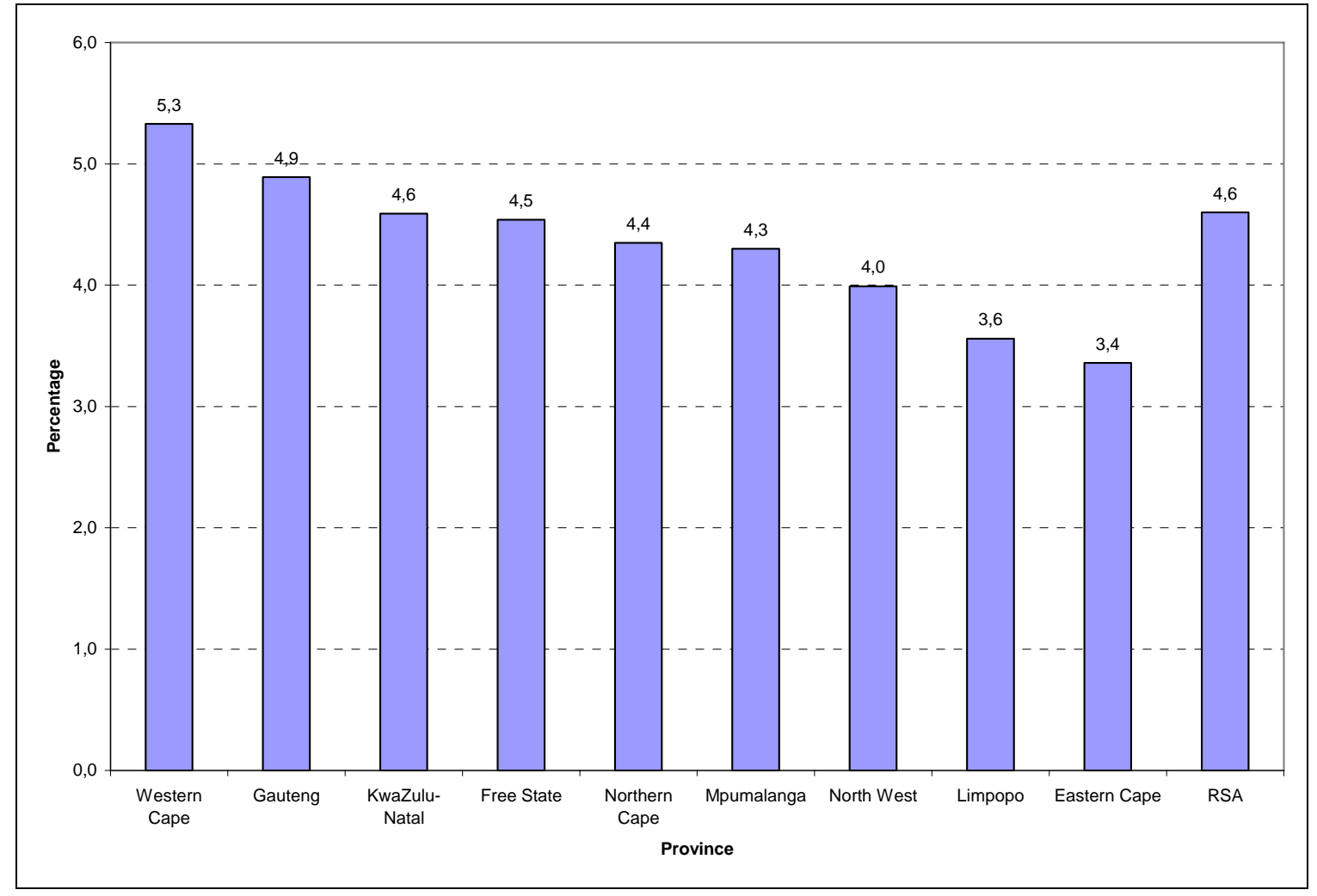

Male-headed households allocated a higher proportion of their household consumption expenditure to recreation and culture $(4,9 \%)$ than female-headed households $(3,9 \%)$. White households allocated $5,5 \%$ and black African households $3,5 \%$ to recreation and culture. Indian/Asian allocated $5,3 \%$ and coloured households allocated $4,7 \%$ to this consumption expenditure group. 


\subsection{Education}

Figure 16 shows that education accounted for $2,4 \%$ of the total household consumption expenditure in South Africa. Expenditure on education among black African households accounted for $2,7 \%$ of their household consumption expenditure, followed by white, Indian/Asian and coloured households at 2,3\%,2,2\% and 1,9\%, respectively.

According to the survey, households headed by women allocated a slightly higher proportion of their consumption expenditure to education $(2,6 \%)$ than male-headed households $(2,4 \%)$.

\section{Figure 16 - Proportion of total household consumption expenditure attributed to education by population group of household head}

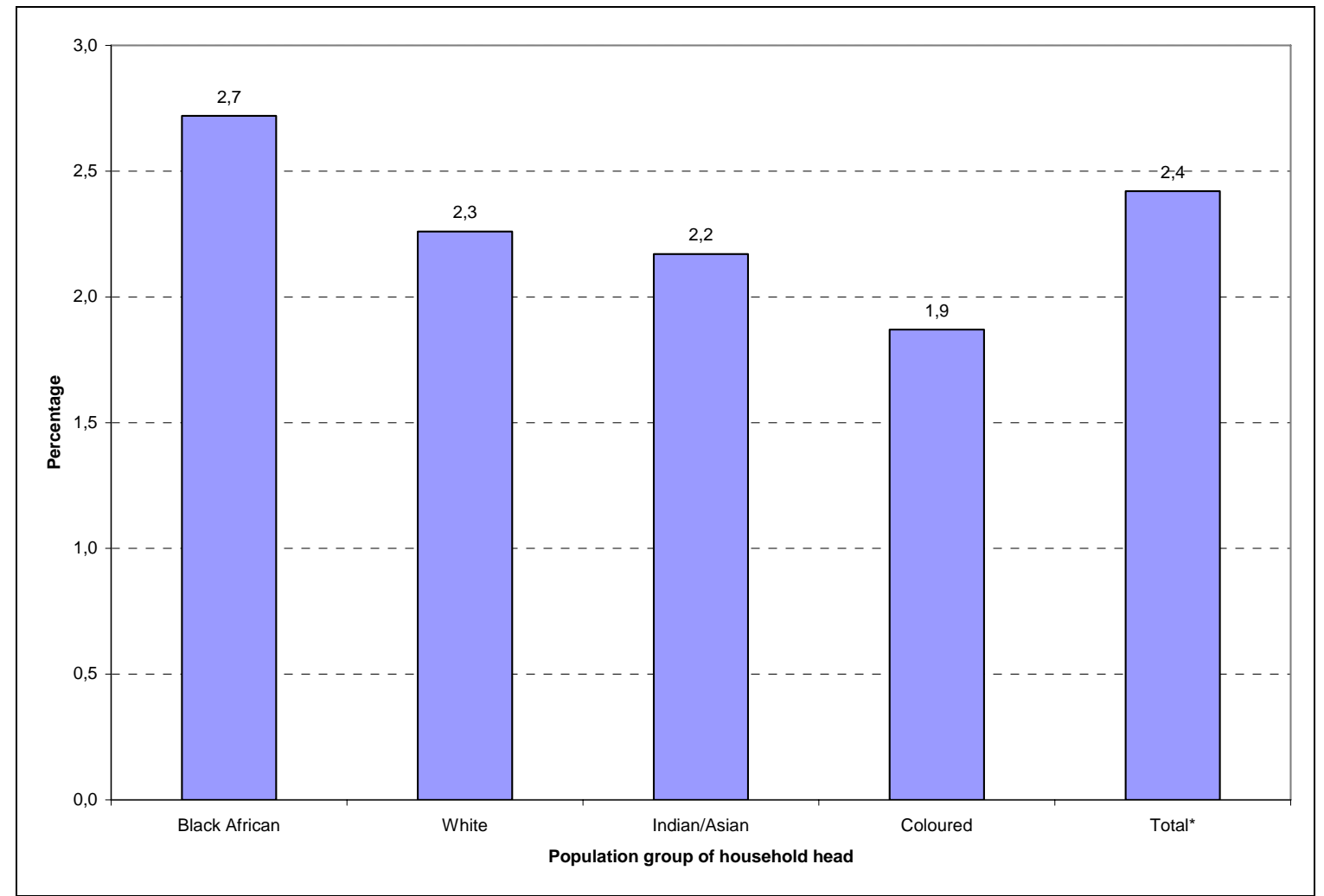

Total* includes unspecified population group of household head

Total household consumption expenditure on education was estimated at approximately R16,9 billion. As with healthcare, education in South Africa is also provided by both the private and the public sectors. Almost three in every five rand $(58,7 \%)$ spent by South African households on education went towards expenses in public educational institutions. The remaining $41,3 \%$ went towards expenses in private educational institutions.

The main components of expenditure on private education differed from one population group to another. Whereas nationally the main component of expenditure on private education was tertiary education, vocational training was the main component of expenditure on private education among black African households. Among Indian/Asian households, the main component of expenditure on private education was pre-primary and primary education.

Among black African households $15,1 \%$ of expenditure on private education was on preprimary and primary education, which was a substantially lower share than the other population groups (coloured 43,4\%, Indian/Asian 41,3\% and white households 29,4\%). 


\subsection{Restaurants and hotels}

According to the survey results, the restaurants and hotels group of expenditure accounted for $2,2 \%$ of household consumption expenditure in the country. Male-headed households allocated a higher proportion of their household budget to restaurant and hotel expenditure. While male-headed households used $2,4 \%$ of their household consumption expenditure towards restaurants and hotels, the corresponding proportion was $1,8 \%$ for female-headed households.

Figure 17 - Proportion of total household consumption expenditure attributed to restaurants and hotels by population group of household head

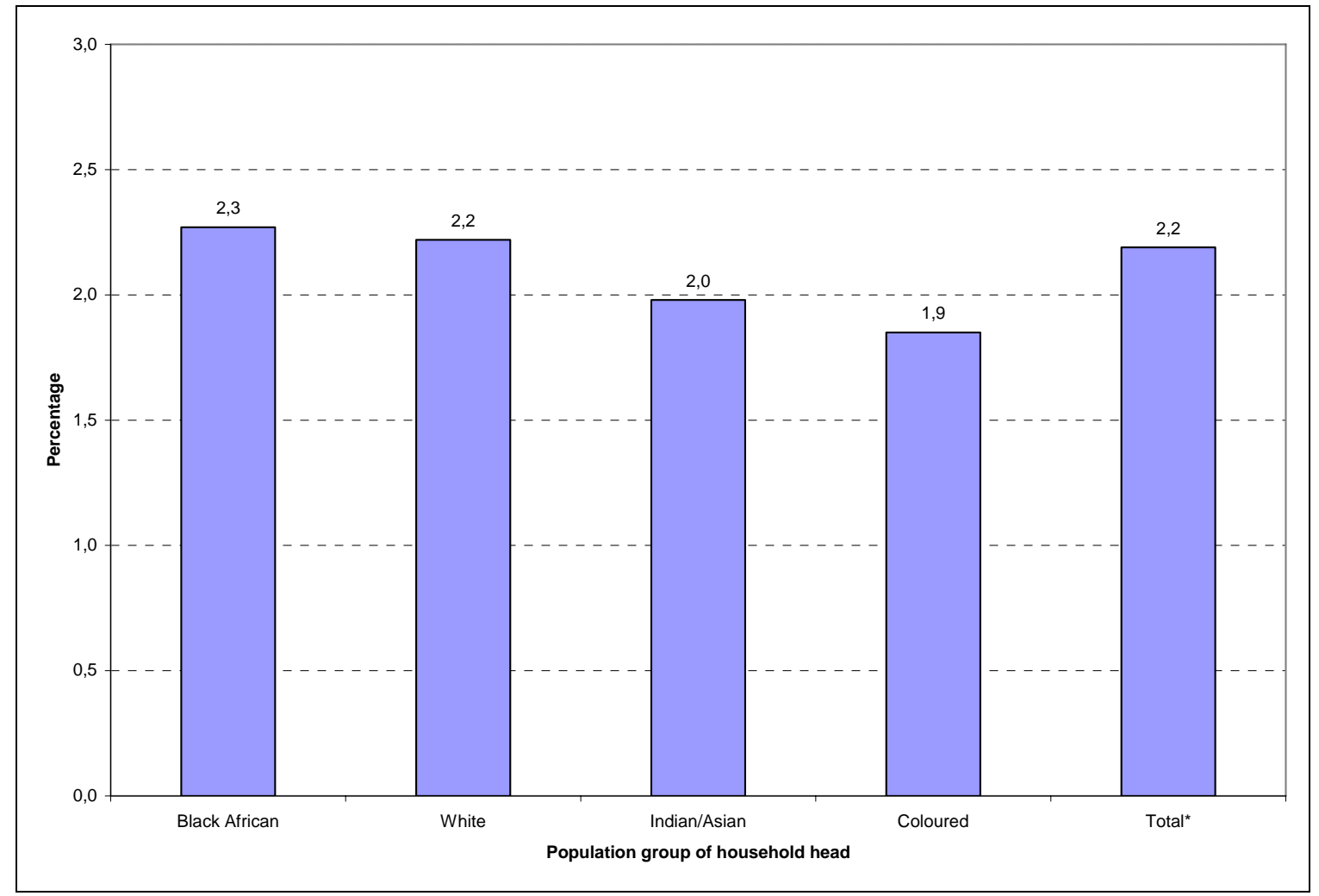

Total* includes unspecified population group of household head

Black African households allocated 2,3\% of their household consumption expenditure to restaurant and hotel services compared with $2,2 \%$ in the case of white households. Whereas the main component of expenditure on restaurants and hotels among white South African households was accommodation services, the main component with respect to black African households was meals in restaurants, cafes, canteens and the like. 


\subsection{Miscellaneous goods and services (including personal care and insurance)}

Miscellaneous goods and services consists of the following expenditure items: personal care (which includes all personal care services, appliances and products, jewellery, clocks and watches), personal effects, social protection, insurance (including insurance related to the dwelling, personal health, and transport), financial services and other services not elsewhere classified. These items together accounted for $14,4 \%$ of household consumption expenditure in 2005/2006. The breakdown by population group of household head is shown in Figure 18.

Figure 18 - Proportion of total household consumption expenditure attributed to miscellaneous goods and services by population group of household head

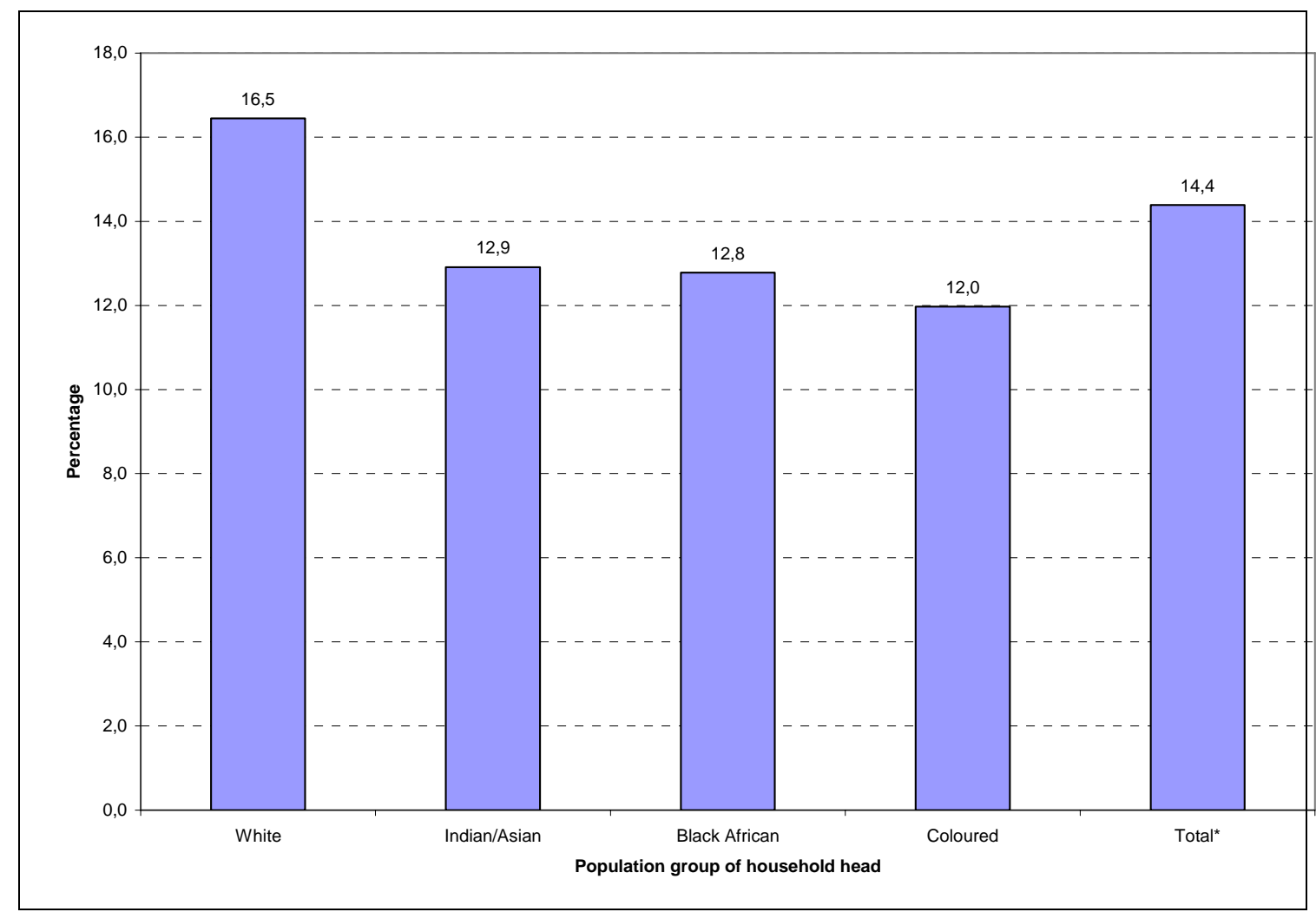

Total$^{*}$ includes unspecified population group of household head 


\section{Explanatory notes}

\subsection{Main objectives of the survey}

The main objectives for conducting the IES 2005/2006 were the following:

- To serve as input into identifying the goods and services that should be included in the Consumer Price Index (CPI) basket of goods and services.

- To collect and provide appropriate and reliable information on income, acquisition and expenditure patterns of a representative sample of households from all types of settlements.

- To provide an independent source of information required to estimate the final private consumption expenditure component of the National Accounts.

The Income and Expenditure Survey scope of work did not include detailed information on poverty measures - although it provides for limited poverty analysis - nor did it cater for detailed information on socio-economic conditions of the households, e.g. on employment.

\subsection{How the IES 2005/2006 was conducted}

The survey was conducted over a period of one year, from September 2005 to August 2006, with sampled households participating for one month and new sub samples of households starting every month. The data collection exercise involved visits to households at the selected dwelling units by trained fieldworkers. Fieldworkers were trained by Stats SA personnel on how to administer the instruments and quality assurors were also trained on the quality assurance processes that were required to be followed at every stage of fieldwork.

Data collection consisted of an extensive interview, which was split and conducted on five separate occasions during the survey month. During the survey month the selected household was required to record all their acquisitions in diaries. A separate diary was used for each of the four weeks of the survey month.

Fieldworkers were hired throughout the period of the survey to complete the main questionnaire by conducting the five interviews and to deliver and collect weekly diaries from households at the selected dwelling units. Whenever needed, fieldworkers were required to assist households regarding how to record their acquisitions in the weekly diary. They were also responsible for completing the summary questionnaire (see paragraph 5.3.3 of this report).

\subsection{The instruments for data collection}

The Income and Expenditure Survey 2005/2006 used three data collection instruments, i.e. the main questionnaire, the weekly diary and the summary questionnaire. 


\subsubsection{Main questionnaire}

The main questionnaire was a booklet of questions. The questions were administered to respondents during the course of the survey month. There were five parts in this questionnaire. The first part of the questionnaire dealt with household characteristics, including area where purchase was made and type of retailer with respect to various products purchased by the household. The next three parts of the questionnaire dealt with different categories of consumption expenditure. The final and fifth part of the questionnaire dealt with income.

\subsubsection{Weekly diary}

This is a booklet that was left with the responding household. The household recorded its daily acquisitions in this booklet in a specific format in columns which enabled the exact nature, type, source and purpose of the item to be correctly processed. A household completed a different diary for each of the four weeks of the survey month.

\subsubsection{Summary questionnaire}

This is the booklet of questions that was for the sole use of the fieldworker. It was structured into various sections. The total value of the item acquired during each week was calculated transferred into the appropriate section of this questionnaire.

The main purpose of the summary questionnaire was to assist the fieldworker to summarise the household's total consumption expenditure on each item for the survey month by transferring information from diaries to the summary questionnaire and therefore ascertain that the household had reported a reasonable distribution of acquired goods and services through checking it against the checklist in each diary. Furthermore, the summary questionnaire served as a code list for fieldworkers when assigning codes for the classification of individual consumption according to purpose (COICOP) to the reported acquired items and in ensuring that high quality item descriptions were received.

\subsection{Time span}

The Income and Expenditure Survey 2005/2006 was conducted over a period of one year between September 2005 and August 2006.

\subsection{Response details}

From the 24000 dwelling units sampled across South Africa, 25192 households were identified. Out of these, there was a sample realisation of $22617(89,8 \%)$ households, with the remaining $2575(10,2 \%)$ households being classified as out of scope due to a number of reasons, such as listing error, vacant dwelling, etc.

Table D below shows the response details for IES 2005/2006. Out of the total sample realisation of 22617 households, 20960 households $(92,7 \%)$ returned a fully completed main questionnaire and four weekly diaries. Eight in every thousand households in the sample (184 households) were classified as partly completed. A household was classified as partly completed when either its main questionnaire or the available weekly diaries or both were partly completed. Households which were classified as completed and partly completed added together (21 144 households), constituted the total response rate, which is $93,5 \%$ of the total sample realisation.

The rest of the households in the sample were classified as non-response. The largest nonresponse was made up of $780(3,1 \%)$ of the households, which were disqualified either for not having completed a main questionnaire or for having less than two weeks' diary information. This was followed by $480(1,9 \%)$ of the households, which refused to participate in the survey; $199(0,8 \%)$ households which fieldworkers failed to establish contact with; and $14(0,1 \%)$ of the households whose information was judged to be unusable. 
Table D - Response details for IES 2005/2006

\begin{tabular}{|l|r|r|l|}
\hline $\begin{array}{l}\text { Classification of household } \\
\text { response }\end{array}$ & $\begin{array}{r}\text { Number of } \\
\text { households }\end{array}$ & Percentage (\%) & Type of response \\
\hline Completed & 20960 & 83,2 & Response \\
\hline Non-contact & 199 & 0,8 & Non-response \\
\hline Refused & 480 & 1,9 & Non-response \\
\hline Partly completed & 184 & 0,7 & Response \\
\hline No usable information & 14 & 0,1 & Non-response \\
\hline Disqualified & 780 & 3,1 & Non-response \\
\hline Total sample realisation & $\mathbf{2 2 6 1 7}$ & $\mathbf{8 9 , 8}$ & \\
\hline Vacant dwelling & 1577 & 6,2 & Out of scope \\
\hline Listing error & 270 & 1,1 & Out of scope \\
\hline Other & 728 & 2,9 & Out of scope \\
\hline Total & $\mathbf{2 5 1 9 2}$ & $\mathbf{1 0 0 , 0}$ & \\
\hline
\end{tabular}

\subsection{Data}

\subsubsection{Data organisation}

Data collected from the IES 2005/2006 had to be reorganised for it to make sense to the user and to facilitate further analysis. Information was collected on various expenditure items both for the survey month and for the eleven months prior to the survey. This information had to be combined to give an estimated annual figure. The process of doing this is referred to as annualisation. It enables us to have a single annual figure of expenditure per expenditure item.

Since the survey took place over a period of twelve months, between September 2005 and August 2006, it was necessary to benchmark the reported expenditure to March 2006 which was midway into the survey year. So, expenditure which took place before the end of February 2006, i.e. before March 2006, was inflated to March 2006 prices, and expenditure which took place after March 2006 was deflated back to March 2006 prices. Expenditure items that do not change over the year, e.g. annual school fees, hospital services, etc., were left unchanged.

\subsubsection{Imputations}

There are two types of non-response, namely, unit non-response and item non-response. Unit non-response is dealt with during weighting, which is discussed in the next section of this report. To deal with item non-response, imputations had to be carried out on the data at different levels. It is important to note though, that when dealing with IES 2005/2006 data, careful interpretation of data items is essential. A zero entry would not necessarily translate into a non-response or a missing item as it could well mean that no purchase was made. So, clear guidelines had to be followed to identify cases of item non-response. It was only in cases where item non-response was identified without doubt that imputation was done.

Imputations on the IES data were done at two levels:

- imputing for missing diaries; and

- imputing for item non-response. 


\subsubsection{Imputing for missing diaries}

A household was required to complete four weekly diaries and a main questionnaire for a period of a month. Some households for various reasons such as fatigue, moving from a selected dwelling unit to another, etc., did not complete all four weeks' diaries. It was decided that a household needed to have completed at least two weeks' diaries to be included in the final data set. Households with less than two weeks' diaries completed were disqualified and were treated as non-response. The same was done with households that had only diaries but no main questionnaire. These too were treated as non-response.

Missing diaries for households with two or three weeks' diaries were imputed. This was done as follows:

If a household had diary information for two weeks, expenditure from the two weeks' diaries was added together and the sum was divided by two. The result was then used to impute diary information for each of the missing two weeks.

Similarly, if a household had diary information for three weeks, expenditure from the three weeks' diaries was added together and the sum was divided by three. The result was then used to impute for the missing diary information for the fourth week.

\subsubsection{Imputing for item non-response}

Imputations were done for missing data on imputed rent, expenditure on rent for a rented dwelling unit and for a dwelling unit that was occupied rent-free, value of a dwelling unit, and individual income. Most of the data items that required imputation were related to housing, and standard procedures used for estimation of housing services had to be used.

There are three different methods which are commonly used to measure housing services from owner-occupied dwelling units, and these include the following:

- interest on loans and mortgage bonds;

- imputed rent for owner occupied dwelling units as estimated by respondents; and

- percentage of the value of the house as an estimate of the rental value of the dwelling unit.

Interest on loans and mortgage bonds data collected were poor, and so were data on imputed rent for owner-occupied dwelling units. Therefore, a decision was taken to use a percentage of the value of a house as an estimate for the annual rent of a dwelling unit. It was agreed that $7 \%$ of the value of the house be used to estimate annual rent in this instance. The decision was in agreement with the findings of research done by a private company on the South African Property Market. This report analyses and reports on the latest trends in most sectors of the property market in the main and some secondary cities of South Africa. The report suggests that the gross income yield on a house is approximately $7 \%$ per annum of the current value of the property.

Regarding housing, imputations for item non-response were done in the following instances: Imputed rent was imputed for 1045 (4,9\% of the households); expenditure on rent for a rented dwelling unit was imputed for 240 (1,1\% of the households); expenditure on rent for a dwelling unit which was occupied rent-free was imputed for 152 (less than $0,7 \%$ of the households); and value of a dwelling unit was imputed for 3788 (17,9\% of the households). The same procedure of imputation was followed for these variables.

Imputations for income were made in $1706(3,8 \%)$ cases of persons within a household who reported that they had a source of income but did not report a value of income.

Basically, imputations were carried out for missing items according to the following general procedure: 
Households with similar characteristics as the ones with missing data regarding a particular item were identified. Variables such as province, settlement type, type of dwelling unit, number of rooms and value of the house were used to match households. The average amount for a particular item as calculated from households of similar characteristics was used to impute the missing data.

\subsubsection{Treatment of special items}

Expenditure-in-kind refers to items that have been acquired by a household without paying for them. It is important to note that if a household receives an item from another household it is a transaction that is seen as consumption expenditure as well as income for the receiving household. For the giving household it is regarded as a transfer to another household and not part of consumption expenditure. For IES 2005/2006 these were measured from the receiving household, i.e. income-in-kind received.

Expenditure-in-kind is not included in total household consumption expenditure as it has no market price. Nevertheless expenditure-in-kind was measured and can be used for analysis purposes.

The following categories of expenditure are excluded when identifying goods and services to be included in the total household consumption expenditure:

1. All items which are considered to be investments because they add value to a dwelling unit such as improvements, additions and alterations; services for improvements, additions and alterations; security structures; building materials not for maintenance and repair; labour and material for improvements, additions and alterations; and life insurance on mortgage bonds.

2. All items which are considered to be income-in-kind such as free water; free sanitation; free electricity; estimated value of private use of a company car or similar vehicle; value of discounted fares for educational purposes; medical aid contributions by employer - households do not spend money on these items.

3. All items identified as: interest on mortgage bonds; subsidy on payment of mortgage; capital payments (including deposit) and other payments such as transfer duty, transfer costs and registration of mortgage bond. A decision was taken to rather use imputed rent. Annual imputed rent was estimated at $7 \%$ of the actual value of the dwelling unit (see section 5.6.2.2 above).

4. Items like seed, fertilizer, feed, livestock, services (e.g. ploughing, veterinary - not for pets), processing (e.g. grinding, milling and slaughtering) and other items from own production - as they are input costs. Instead, products from own production should be included in the basket of goods and services.

5. All in-cash maintenance of family and/or remittances to family members and dependants living elsewhere (including alimony/palimony paid to ex-wife/ex-husband and children); gifts to persons who are not members of the household (excluding gifts-in-kind and cash gifts); tribal cash levies (not for housing); and tribal levies-inkind (not for housing) - such expenditure is measured from the receiving households since households would have acquired these items for the sole purpose of giving them away to other households..

6. All panel beating repairs paid for by the insurance company or other party, and other repair work paid for by the insurance company or other party - these are already accounted for elsewhere, e.g. amount paid for car insurance. 
The funds available to a household (from income, past savings and borrowing) are also committed to a range of non-consumption items, including various forms of saving, investment and the repayment of principal and interest on various forms of borrowing. These uses of a household's funds, while of interest too many users in their own right, are not central to the income and consumption expenditure focus of the IES. While Stats SA will make data on non-consumption commitments available, users should treat them cautiously, as the concepts involved are complex and not easy for households to report reliably. 


\section{Limitations of the survey}

The planning and preparation for fieldwork for IES 2005/2006 started early 2004. Sampling for this survey was done, using the latest listing (2003) of dwelling units available at the time. Data collection began in September 2005. Due to the time lapse between the planning, selection of the sample and implementation of the sample, many of the listings were outdated by the time of actual data collection. In December 2005 an updated Dwelling Unit (DU) sample was selected based on 2004 DU listings. In cases where the listings were not reflecting the DUs accurately, relisting of PSUs was done. This problem became worse as the survey month got closer to the end of the survey period. The problem resulted into two major limitations during the survey, namely the movement of households and boundary changes.

\subsection{Movement of households}

There were three distinct types of movement of households that affected the scope of the survey, and these were:-

- movement of households from one type of settlement to another;

- seasonal movement of households, especially in farm areas; and

- movement of households in and out of holiday homes, especially in coastal areas.

There were cases when there was movement of households from one type of settlement to another, and the most distinct was where people had moved from informal settlements to new RDP housing locations. In such cases, listings of the PSU from which the people moved would not be reflective of what is on the ground as the vacated dwelling units would have been demolished. In such cases relisting was done to obtain a proper DU listing of the PSU.

The movement of households due to seasonality was distinct in farm areas where farm workers are hired and accommodated during harvest time, especially in Western Cape. In some instances dwelling units for farm workers that were appearing on the list would now be out of scope as vacant dwellings.

In the coastal areas there was movement of households in and out of their holiday homes during different times of the year. This also created out of scope problems when previously occupied holiday homes became vacant dwellings or when different households occupied the holiday homes within the survey period.

\subsection{Boundary changes}

The Demarcation Board constantly updates administrative boundaries. Since 2001, when the last population census was conducted, changes in administrative boundaries have affected all provinces except Western Cape and Free State. As many as 907 households in the sample changed provinces due to boundary changes. Since the IES sample was selected based on the 2001 population census information and weights were calculated based on the sample information, these households were assigned weights from their previous provinces. In the final dataset, these households were classified under their new provinces meaning that they moved with their weights from their old to the new provincial classification. 


\section{Technical notes}

\subsection{Sample}

For the IES 2005/2006, a newly designed Master Sample based on the 2001 Population Census Enumeration Areas was used as the sampling frame.

The scope of the Master Sample is national coverage of all households in South Africa and the target population consists of all qualifying persons and households in the country. The Master Sample focuses on private dwelling units, workers' hostels, residential hostels, nurses' and doctors' quarters, but excludes patients in hospitals or clinics, guests in hotels and guest houses, prisoners in prisons, scholars and students in school or student hostels and the aged in old-age homes. In summary, the Master Sample is designed to cover all households living in private dwelling units and workers living in workers' quarters in the country.

The 3000 primary sampling units (PSUs) from the Master Sample were representatively divided into four quarterly allocations of 750 each. Within each quarterly allocation a random sample of 250 PSUs was selected every month using the updated listings (originally using the update of 2003 and as from December 2005 the update of 2004). Eight dwelling units were systematically selected from each of the sampled PSUs for fieldwork. In total, 24000 dwelling units were covered during the twelve months of data collection for the IES 2005/2006. This process ensured that the sample was evenly spread over the twelve months, while it remained nationally representative in each quarter. The Master Sample is used for all household surveys conducted by Statistics South Africa. In cases where the latest updated listings were not reflecting the DUs accurately, relisting of PSUs was done.

\subsection{Coverage}

The IES 2005/2006 included all domestic households, holiday homes and all households in workers' residences such as mining hostels and dormitories for workers. It did not include institutions such as hospitals, prisons, old-age homes, student hostels and dormitories for scholars. Also excluded were boarding houses, hotels, lodges and guest houses.

\subsection{Data collection}

There are three main approaches used to collect data on household consumption expenditure, namely the acquisition, the payment and the consumption approaches. All three methods were used at some stage during data collection for IES 2005/2006.

The acquisition approach entails taking into account the total value of goods and services acquired (not necessarily consumed but for household consumption purposes) during a given period, whether or not they are paid for during the period of collection. This was the general approach followed by the IES 2005/2006 for most of the items. Information on durable, semidurable and non-durable goods was collected using the acquisition approach.

The payment approach takes into account the total payment made for all goods and services in a given period, whether or not they were delivered. This approach was followed when collecting data on expenditure on services such as education, health, insurance, etc.

The consumption approach takes into account the total value of all goods and services consumed or used during a given period. This approach was used when collecting information on own production. 


\subsection{Data processing}

Data processing refers to a class of computer programs that organise and manipulate usually large volumes of numeric data. Data processing involved the processing of completed instruments, i.e. diaries, main questionnaires and the summary questionnaires. Information received from these instruments collected during fieldwork was converted into data represented by numbers or characters. The main method used for this conversion was scanning. All information contained in damaged instruments that could not be scanned was identified and transcribed onto clean instruments in order to be scanned.

\subsubsection{High level processes}

In general, the high level processes covered the following activities.

Boxes containing instruments per PSU were received from the nine Stats SA Provincial Offices and checked into Stores at the Data Processing Centre of Stats SA on the data processing management database that was designed for this purpose. All instruments in each PSU box were checked to ensure that -

- they belonged to the PSU box; and

- they were not damaged.

For purposes of tracking the instruments, ensuring no instruments got lost and quality assurance during the data processing processes, the content of each PSU box was manualcaptured (key-from-paper entry) twice, compared, ensured it matched and stored in the data processing management database. All instruments were then prepared for capturing. Thereafter, the data were captured and converted into electronic format through scanning. To ensure quality electronic data, the data were verified as well as edited and checked for consistency according to the predetermined editing rules. COICOP codes, which were assigned to items acquired by the fieldworkers, were checked to enhance quality. Finally the data were prepared for final output based on the tabulation plan.

\subsubsection{Data processing management system and database}

A data processing management system and database were developed to assist in managing and tracking each PSU box and the instruments contained in each box, and to ensure all instruments are processed during each data processing process.

At each data processing process, the PSU box number was scanned and the PSU box was checked into the relevant data processing process on the data processing management database. An instrument list per PSU box was printed and utilised during the relevant process. On completion of a data processing process, the PSU box was checked out and back into Stores. At any given point during data processing, information was available on progress as well as where a PSU box and instruments could be found.

At the end an account of all sampled dwelling units was prepared and information balanced with information contained in the data processing management database, as well as final electronic edit database. 


\subsubsection{Coding of acquired items}

Coding is the process of assigning numerical values to responses to facilitate data capturing and processing in general. The code list for acquired items was based on the United Nations' Classification of Individual Consumption According to Purpose (COICOP). Codes were assigned to expenditure items, listed in the diaries, by field staff. During data processing, all assigned codes were checked and improved when necessary to ensure and enhance quality.

\subsubsection{Data capturing}

The data were captured through scanning.

The scanning process proceeded as follows:

The Data Processor scanned the PSU box number and checked the PSU box into the scanning process. One PSU box at a time was given to each of the four Scanning Operators to avoid scanning the questionnaires twice. The batches were then taken out of the PSU box and placed in the scanner tray. While scanning the instruments, a visual check was performed on the scanning to ensure that the images were clear of any noise and that the data were clear and readable. The PSU box number and the actual data on each instrument were checked. In the case where the image was too light or too dark or unclear, parameters were adjusted and the batch was rescanned.

After scanning, all information was interpreted and each field contained in each instrument was verified to ensure quality recognition of all information contained in instruments.

The scanned and verified information of each instrument was transferred to an edit database that was created for this purpose.

\subsubsection{Editing}

The electronic transferred data were checked and edited according to the predetermined editing rules for fields contained in each instrument.

Most of the editing rules were categorised into structural edits looking at the relationships between different record types, the basic processing rules that remove false positive reading or noise, the logical editing that determine the inconsistency between fields of the same statistical unit and the inferential edits that search for similarities across the domain. An edit specifications document was developed by a team of Stats SA subject matter specialists and programmers.

\subsubsection{Quality assurance}

Quality assurance (QA) was applied at each process and on each instrument. Furthermore, each process had to perform a quality check on its predecessor. 


\subsection{Weighting the IES 2005/2006}

A two-stage weighting procedure was applied to the IES.

The PSU inclusion probability is given by

$$
P_{P S U}=\frac{n_{P S U}}{N_{P S U}} \cdot n_{S},
$$

where $n_{P S U}$ is the number of households constituting the selected PSU during population census fieldwork, $n_{S}$ is the number of PSUs per stratum, in this case the District Council (DC) and $N_{P S U}$ is the number of households constituting the selected stratum during population census fieldwork.

The household inclusion probability per PSU is given by

$$
P_{H H}=\frac{n_{H H}}{H_{H H}},
$$

where $n_{H H}$ is the number of selected dwelling units per PSU, $H_{H H}$ is the number of dwelling units in the PSU in question at a particular time different from the population census time.

The non-response adjustment factor is given by $\frac{1}{r_{H H}}$, where $r_{H H}$ is the response rate and is given by $r_{H H}=\frac{n_{R E S P}}{n_{T}}$ where $n_{R E S P}$ is the number of responding households and $n_{T}$ is the total number of visited households (in the sampled dwelling units) per PSU.

The design weights adjusted for non-response are now given by

$$
W_{H H}=\frac{1}{P_{P S U} \cdot P_{H H} \cdot r_{H H}}
$$

A SAS macro called CALMAR was used to benchmark $W_{H H}$ to the population estimates. 


\subsection{Reliability of estimates}

\subsubsection{Background}

The IES 2005/2006 sample was selected using a two-stage sample design where the first stage involved the selection of PSUs and the second stage involved the selection of eight dwelling units (DUs). The PSUs were selected with probability proportion to sample size and within each PSU the DUs were selected according to systematic random sampling. The PSU sample size was 3000 and the DU sample size per PSU was eight. This type of design is called complex multi-stage sample. Variance estimation for complex multi-stage sample designs is a complex process since it involves clustering, post-stratification and sometimes calibration of the weights. Available packages for analysis and estimation of variances are computer intensive and require large disk space and memory. As an approximation Stats SA uses the SAS Proc SURVEYMEANS procedure to estimate the variability measures. The analysis variable of interest is consumption by various categorical variables.

\subsubsection{Analysis of coefficients of variation}

Analysis of coefficients of variation provides a basis for assessing the reliability of an estimate. Tables $\mathrm{E}$ to $\mathrm{H}$ show the estimated mean consumption expenditure of households with respect to various categorical variables in the data. An estimate is considered to be reliable if its coefficient of variation lies between 0 and 0,1 , whereas an estimate whose coefficient of variation falls between 0,1 and 0,33 should be used with caution.

Table E - Mean consumption expenditure by sex of household head with coefficients of variation and confidence intervals for mean expenditure

\begin{tabular}{|l|r|r|r|r|}
\hline Sex & Mean & $\begin{array}{r}\text { Lower confidence } \\
\text { limit for the mean }\end{array}$ & $\begin{array}{r}\text { Upper } \\
\text { confidence } \\
\text { limit for the } \\
\text { mean }\end{array}$ & $\begin{array}{r}\text { Coefficient of } \\
\text { variation }\end{array}$ \\
\hline Male & 67128 & 61859 & 72398 & 0,04 \\
\hline Female & 38927 & 36111 & 41744 & 0,04 \\
\hline Unspecified & 43783 & 14730 & 72836 & 0,34 \\
\hline
\end{tabular}

Table $\mathrm{E}$ shows the distribution of mean consumption expenditure by sex of the household head. The coefficients of variation show that the variability within the two sex categories is $4 \%$, which is very low. The estimates of mean household consumption expenditure with respect to sex are considered to be reliable since both coefficients of variation fall between 0 and 0,1 . Out of a total response of 21144 households, there were only $19(0,09 \%)$ households with unspecified sex of the household head. The unspecified category is a result of a random process which does not follow the sample design. 
Table F - Mean consumption expenditure by main expenditure group and mean income with coefficients of variation and confidence intervals for mean expenditure and mean income

\begin{tabular}{|c|c|c|c|c|}
\hline Main group & Mean & $\begin{array}{r}\text { Lower } \\
\text { confidence } \\
\text { limit for the } \\
\text { mean }\end{array}$ & $\begin{array}{r}\text { Upper } \\
\text { confidence } \\
\text { limit for } \\
\text { the mean }\end{array}$ & $\begin{array}{r}\text { Coefficient } \\
\text { of } \\
\text { variation }\end{array}$ \\
\hline $\begin{array}{l}\text { Main expenditure group } \\
\text { Food and non-alcoholic } \\
\text { beverages }\end{array}$ & 8105 & 7857 & 8353 & 0.02 \\
\hline Alcoholic beverages and tobacco & 647 & 601 & 694 & 0,04 \\
\hline Clothing and footwear & 2781 & 2664 & 2897 & 0,02 \\
\hline $\begin{array}{l}\text { Housing, water, electricity, gas } \\
\text { and other fuels }\end{array}$ & 13245 & 12061 & 14429 & 0,05 \\
\hline $\begin{array}{l}\text { Furnishings, household } \\
\text { equipment and routine } \\
\text { maintenance of the dwelling }\end{array}$ & 3868 & 3579 & 4156 & 0,04 \\
\hline Health & 933 & 784 & 1082 & 0,08 \\
\hline Transport & 11180 & 10052 & 12308 & 0,05 \\
\hline Communication & 1969 & 1820 & 2119 & 0,04 \\
\hline Recreation and culture & 2582 & 2304 & 2860 & 0,05 \\
\hline Education & 1356 & 1142 & 1570 & 0,08 \\
\hline Restaurants and hotels & 1232 & 1107 & 1358 & 0,05 \\
\hline $\begin{array}{l}\text { Miscellaneous goods and } \\
\text { services }\end{array}$ & 8081 & 7239 & 8924 & 0,05 \\
\hline Other unclassified expenses & 172 & 142 & 202 & 0,09 \\
\hline Consumption-in-kind & 1549 & 1348 & 1749 & 0.07 \\
\hline Income & 74589 & 68728 & 80449 & 0,04 \\
\hline Income-in-kind & 1549 & 1348 & 1749 & 0,07 \\
\hline
\end{tabular}

All the estimates for the mean household consumption expenditure by main expenditure group and income can be viewed with confidence as their respective coefficients of variation fall between 0 and 0,1 . 
Table G - Mean consumption expenditure by province with coefficients of variation and confidence intervals for mean expenditure

\begin{tabular}{|l|r|r|r|r|}
\hline Province & Mean & $\begin{array}{r}\text { Lower confidence } \\
\text { limit for the mean }\end{array}$ & $\begin{array}{r}\text { Upper } \\
\text { confidence } \\
\text { limit for the } \\
\text { mean }\end{array}$ & $\begin{array}{r}\text { Coefficient of } \\
\text { variation }\end{array}$ \\
\hline Western Cape & 102977 & 81455 & 124498 & 0,11 \\
\hline Eastern Cape & 39141 & 33382 & 44900 & 0,08 \\
\hline Northern Cape & 38389 & 33979 & 42799 & 0,06 \\
\hline Free State & 50181 & 41404 & 58958 & 0,09 \\
\hline KwaZulu-Natal & 44612 & 38557 & 50666 & 0,07 \\
\hline North West & 43784 & 34087 & 53482 & 0,11 \\
\hline Gauteng & 77700 & 66894 & 88505 & 0,07 \\
\hline Mpumalanga & 43026 & 34921 & 51130 & 0,10 \\
\hline Limpopo & 29042 & 25713 & 32370 & 0,06 \\
\hline
\end{tabular}

Table $G$ above shows that the coefficient of variation for the estimated mean household consumption expenditure in most of the provinces is between 0 and 0,1 (below 10\%). The highest coefficient of variation was with respect to the provinces of Western Cape and North West at $11 \%$. Although ideally, the estimates for the two provinces should be treated with caution as their coefficients of variation fall outside the more comfortable range of 0 to 0,1 , the variability of $11 \%$ is still very low. This shows that the survey has been stable within provinces. It also means that the rate of homogeneity within province is very low and thus the estimates can be interpreted with confidence. The province with the highest mean household consumption expenditure is Western Cape (R102 977), followed by Gauteng (R77 700). The province with the lowest mean household consumption expenditure figure is Limpopo (R29 042).

Table $\mathrm{H}$ - Mean consumption expenditure by population group of household head with coefficients of variation and confidence intervals for mean expenditure

\begin{tabular}{|l|r|r|r|r|}
\hline $\begin{array}{l}\text { Population } \\
\text { group of } \\
\text { household } \\
\text { head }\end{array}$ & Mean & $\begin{array}{r}\text { Lower confidence } \\
\text { limit for the mean }\end{array}$ & $\begin{array}{r}\text { Upper } \\
\text { confidence limit } \\
\text { for the mean }\end{array}$ & $\begin{array}{r}\text { Coefficient of } \\
\text { variation }\end{array}$ \\
\hline Black African & 30509 & 29053 & 31964 & 0,02 \\
\hline Coloured & 58805 & 51926 & 65683 & 0,06 \\
\hline Indian/Asian & 104533 & 84320 & 124747 & 0,10 \\
\hline White & 198632 & 181809 & 215454 & 0,04 \\
\hline Unspecified & 67278 & 43717 & 90839 & 0,18 \\
\hline
\end{tabular}

In Table $\mathrm{H}$ above, the coefficients of variation show that there is minimal variability within population groups. Out of 21144 households which responded, there were $21(0,1 \%)$ households where the population group of household head was not specified. 


\section{Definition of terms}

Acquisition approach

The acquisition approach entails taking into account the total value of goods and services actually acquired during a given period, whether or not they were wholly paid for or wholly consumed during the period of collection. This refers to the price of the item at the time of acquisition excluding finance charges and/or discounted amount.

\section{Classification of Individual Consumption According to Purpose (COICOP)}

\section{Consumer Price Index (CPI)}

\section{Consumption expenditure} Consumption approach
(own production)

Diary

\section{Durable goods}

COICOP is an international system of classification of goods and services based on the purpose for which households use the goods and services.

The CPI can be described as a series of numbers showing how the average price level of goods and services bought by a typical consumer or household changes over time. The main purpose of the $\mathrm{CPI}$ is to measure changes in the price level of consumer goods and services.

In order to calculate the $\mathrm{CPI}$, information regarding the change in prices of consumer goods and services and the relevant importance (weights) of those goods and services are essential. The relevant importance may be determined from the results of the IES.

Consumption expenditure refers to all goods and services that are acquired for own consumption and privately used by household members. This excludes any items and services acquired for business purposes. For example, if a respondent takes a taxi to the beach to relax, he/she is consuming the services of the taxi. This is for own consumption, but if the respondent takes a taxi to town to buy stock for his/her spaza shop, then he/she is consuming the services of the taxi for business purposes. Consumption expenditure excludes transfers to other households.

The consumption approach takes into account the total value of all goods and services consumed (or used) during a given period. For example, if a fridge has been delivered to the household but the household has not started paying for it, but has begun to consume the services of the fridge, then an estimated value of what has been used so far is attached to the fridge.

This is a booklet that is left with the responding household on the first visit. The household records its daily acquisitions in this booklet in a specific format in columns which enables the exact nature, type, source and purpose of the item to be correctly processed.

Durable goods refer to items that last for a long time. Usually household members acquire such items once in years. Examples of durable goods are household kitchen appliances, household information and entertainment appliances, cars, furniture, etc. 
Dwelling Unit (DU)

Enumeration area (EA)

\author{
Formal and informal \\ sector
}

\section{Household}

Household head/acting household head
A dwelling unit (DU) is any structure or part of a structure or group of structures occupied or meant to be occupied by one or more than one household. It can also be described as any structure or part of a structure, which is vacant and/or under construction, but is likely to be occupied at the time of the survey. In workers' hostels: (1) where rooms are occupied by individual persons or households, then each room is treated as a dwelling unit; and (2) where hostel dwellers live in dormitories/ communal rooms, each bed is listed separately and treated as a dwelling unit.

An enumeration area is the smallest geographical unit (piece of land) into which the country is divided for census and survey purposes. For survey purposes EAs can be combined to form Primary Sampling Units (PSUs).

For the purpose of the IES, the formal/informal sector is not defined but is based on the respondents' perception of what constitutes formal/informal. Indicators such as the location of the business (e.g. side of the street, garage, back-yard shack) and/or whether or not the business is registered are used to determine the sector.

A household is defined as a person, or group of persons who, on average, occupies a common dwelling unit (or part of it) for at least four days a week during the four weeks prior to the interview, and they together provide themselves with food and other essentials for living. Basically, they live together and share resources as a unit. Other explanatory phrases used are "eating from the same pot" and "cooking and eating together".

The household head is not defined but the respondents need to decide on who is the household head. A head of household (by definition of household) must be a member of the household. If household members cannot decide who the household head is, then the following criteria, in order of precedence or preference is used:

The person who -

- owns the household accommodation;

- is responsible for the rent of the household accommodation;

- has the household accommodation as an allowance (entitlement), etc.;

- has the household accommodation by virtue of some relationship to the owner, lessee, etc. who is not in the household; or

- makes the most decisions in the household. 
Income and expenditure survey (IES) main questionnaire

Income and expenditure survey (IES) summary questionnaire

\section{Income-in-kind/ Expenditure-in-kind}

Non-durable goods

Own production

Primary sampling unit (PSU)

\section{Rural}

Semi-durable goods

Settlement type

Urban

Vacant dwelling
This is a booklet of questions that is administered to respondents over the course of the month. There are five parts in this questionnaire. Each of the first four parts deals with a different category of consumption expenditure, while the final (fifth) part deals with income.

This is a booklet of questions that is for the sole use of the fieldworker and is not seen by the respondent. It is structured into various sections. The total value of acquisitions of each item is calculated per week and transferred into the appropriate section of this questionnaire. The main purpose of this questionnaire is to code consumption expenditure items according to COICOP and for quality assurance purposes.

This refers to items acquired by households without paying for them, e.g. bursaries, subsidies from employer, free medical services, private use of a company car or similar vehicle, value of discounted fares for educational purposes, grants from schools and other educational institutions, excluding gifts and maintenance from other households members.

Non-durable goods refer to items that do not last long, for example food and personal care items. Households acquire these items on a daily or weekly basis.

Own production is the activity of producing goods that the household can consume or sell in order to supplement the household income. Many households - especially low-income households - need to grow food items such as vegetables, mealies, etc., or to keep chickens or livestock to consume and/or sell so that they can provide more adequately for themselves.

A primary sampling unit (PSU) is a geographical area that consists of either one or more enumeration areas of the same type (and not necessarily contiguous) that together have at least one hundred dwelling units.

Rural refers to farms and traditional areas characterised by low population densities, low levels of economic activity and low levels of infrastructure, such as commercial farms and tribal areas.

Semi-durable goods refer to items that last longer than nondurable goods but still need replacing more often than durable goods. Examples are clothing, shoes and material for clothing. Households acquire these items from time to time, once a year or several times in a year.

Settlement type refers to the classification of an area according to settlement characteristics.

Urban refers to formal cities and towns characterised by higher population densities, high levels of economic activity and high levels of infrastructure, such as formal settlements, metropolitan areas, informal settlements and high-wall settlements.

A vacant dwelling is a dwelling that is uninhabited, i.e. no one lives there. 
Vacant (EA)

Vacant stand

Workers' hostels
A vacant EA refers to a demarcated land that is unoccupied (i.e. not populated).

A vacant stand is a stand, fenced or unfenced, which has no observable structure erected on it.

Workers' hostels are communal living quarters for workers, provided by a public organisation such as a local authority or a private organisation such as a mining company. These are residential dormitories which were established for migrant workers during the apartheid era, and they continue to house people working in certain industries, such as the mining industry (see also dwelling unit). 


\section{Population}

Table 1.1 - Population by province and sex of household head **

\begin{tabular}{|c|c|c|c|c|c|c|c|c|c|c|c|}
\hline \multirow{2}{*}{\begin{tabular}{|l} 
Population \\
group
\end{tabular}} & \multirow[t]{2}{*}{ Sex } & \multicolumn{10}{|c|}{$N(1000)$} \\
\hline & & $\begin{array}{r}\text { Western } \\
\text { Cape }\end{array}$ & \begin{tabular}{r|} 
Eastern \\
Cape
\end{tabular} & \begin{tabular}{r|} 
Northern \\
Cape
\end{tabular} & Free State & $\begin{array}{r}\text { KwaZulu- } \\
\text { Natal }\end{array}$ & North West & Gauteng & Mpumalanga & Limpopo & Total \\
\hline \multirow[t]{4}{*}{ Black African } & Male & 682 & 2851 & 310 & 1266 & 3955 & 1451 & 3852 & 1581 & 2466 & 18415 \\
\hline & Female & 575 & 3106 & 295 & 1203 & 4590 & 1388 & 3542 & 1720 & 2747 & 19166 \\
\hline & Unspecified & & & & & & & & & 14 & \\
\hline & Total & 1259 & 5963 & 612 & 2471 & 8552 & 2842 & 7394 & 3303 & 5227 & 37623 \\
\hline \multirow[t]{4}{*}{ Coloured } & Male & 1216 & 240 & 211 & 83 & 99 & 50 & 151 & * & * & 2058 \\
\hline & Female & 1310 & 253 & 231 & 66 & 88 & 55 & 124 & * & * & 2133 \\
\hline & Unspecified & & & & & & & & - & & \\
\hline & Total & 2530 & 493 & 442 & 149 & 187 & 105 & 274 & * & * & 4194 \\
\hline \multirow[t]{4}{*}{ Indian/Asian } & Male & 14 & * & * & 15 & 379 & 10 & 155 & * & 10 & 596 \\
\hline & Female & 15 & * & * & * & 399 & 10 & 120 & 4 & 7 & 567 \\
\hline & Unspecified & & - & - & & & - & & - & - & \\
\hline & Total & 29 & * & * & 20 & 777 & 20 & 275 & * & 18 & 1163 \\
\hline \multirow[t]{4}{*}{ White } & Male & 455 & 195 & 39 & 160 & 206 & 176 & 813 & 106 & 56 & 2207 \\
\hline & Female & 464 & 187 & 37 & 147 & 200 & 154 & 804 & 92 & 59 & 2145 \\
\hline & Unspecified & & & - & & & & & - & - & \\
\hline & Total & 922 & 384 & 76 & 307 & 407 & 330 & 1620 & 198 & 116 & 4361 \\
\hline \multirow[t]{4}{*}{ Unspecified } & Male & * & * & - & * & * & - & * & - & $*$ & 23 \\
\hline & Female & - & * & - & * & - & - & 10 & - & * & 23 \\
\hline & Unspecified & - & * & - & - & * & - & - & - & - & * \\
\hline & Total & * & * & - & 11 & * & - & 18 & - & * & 50 \\
\hline \multirow[t]{4}{*}{ Total } & Male & 2373 & 3296 & 565 & 1527 & 4640 & 1687 & 4978 & 1693 & 2540 & 23299 \\
\hline & Female & 2365 & 3550 & 566 & 1430 & 5277 & 1607 & 4600 & 1819 & 2819 & 24034 \\
\hline & Unspecified & & & & & 12 & & & & 14 & 58 \\
\hline & Total & 4746 & 6854 & 1138 & 2959 & 9929 & 3296 & 9582 & 3513 & 5373 & 47391 \\
\hline
\end{tabular}

Due to rounding, figures do not necessarily add up to tota

* For all values of 10000 or lower the sample size is too small for reliable estimates

- No respondents

** Population as per mid-year estimates, June 2006 


\section{Population}

Table 1.2 - Urban population by province and sex of household head **

\begin{tabular}{|c|c|c|c|c|c|c|c|c|c|c|c|}
\hline \multirow{2}{*}{$\begin{array}{l}\text { Population } \\
\text { group }\end{array}$} & \multirow[t]{2}{*}{ Sex } & \multicolumn{10}{|c|}{$N(100)$} \\
\hline & & $\begin{array}{r}\text { Western } \\
\text { Cape }\end{array}$ & \begin{tabular}{r|} 
Eastern \\
Cape
\end{tabular} & $\begin{array}{r}\text { Northern } \\
\text { Cape }\end{array}$ & Free State & $\begin{array}{r}\text { KwaZulu- } \\
\text { Natal }\end{array}$ & \begin{tabular}{r|} 
North \\
West
\end{tabular} & Gauteng & Mpumalanga & Limpopo & Total \\
\hline \multirow[t]{3}{*}{ Black African } & Male & 663 & 1001 & 186 & 982 & 1571 & 555 & 3695 & 622 & 263 & 9539 \\
\hline & Female & 561 & 1035 & 170 & 956 & 1796 & 495 & 3418 & 617 & 256 & 9305 \\
\hline & $\begin{array}{l}\text { Unspecified } \\
\text { Total }\end{array}$ & 1226 & 2037 & 356 & $1941^{*}$ & 3368 & $1050^{-}$ & $7114^{*}$ & $1240^{\star}$ & 519 & 18851 \\
\hline \multirow[t]{4}{*}{ Coloured } & Male & 1101 & 213 & 180 & 77 & 92 & 45 & 147 & * & * & 1860 \\
\hline & Female & 1190 & 233 & 203 & 60 & 85 & 49 & 120 & * & * & 1943 \\
\hline & Unspecified & & & & & & & & & & \\
\hline & Total & 2294 & 446 & 383 & 137 & 176 & 93 & 267 & * & * & 3806 \\
\hline \multirow[t]{4}{*}{ Indian/Asian } & Male & 14 & * & $*$ & 15 & 372 & 10 & 155 & * & 10 & 589 \\
\hline & Female & 15 & * & $*$ & * & 393 & 10 & 120 & * & * & 560 \\
\hline & Unspecified & & & & & & & & & & \\
\hline & Total & 29 & * & * & 20 & 765 & 20 & 275 & * & 17 & 1148 \\
\hline \multirow[t]{4}{*}{ White } & Male & 433 & 183 & 30 & 141 & 199 & 164 & 781 & 94 & 48 & 2072 \\
\hline & Female & 444 & 178 & 27 & 129 & 193 & 143 & 776 & 84 & 50 & 2024 \\
\hline & Unspecified & & & & & & & & & & \\
\hline & Total & 880 & 364 & 56 & 269 & 393 & 306 & 1560 & 178 & 98 & 4105 \\
\hline \multirow[t]{4}{*}{ Unspecified } & Male & * & * & - & * & - & - & * & & - & 18 \\
\hline & Female & 1 & * & & * & 1 & - & 10 & & - & 20 \\
\hline & Unspecified & - & * & - & - & * & - & - & & - & * \\
\hline & Total & * & * & - & 11 & * & - & 18 & - & - & 42 \\
\hline \multirow[t]{3}{*}{ Total } & Male & 2216 & 1405 & 400 & 1217 & 2234 & 773 & 4785 & 720 & 326 & 14077 \\
\hline & Female & 2210 & 1451 & 405 & 1159 & 2467 & 697 & 4444 & 707 & 313 & 13853 \\
\hline & Unspecified & 4433 & $2860^{*}$ & - & 2378 & - & - & * & * & - & $\begin{array}{r}22 \\
2705 ?\end{array}$ \\
\hline & l otal & 4435 & 2860 & 804 & $23 / 8$ & 4700 & 1470 & 9234 & 1428 & 639 & 27952 \\
\hline
\end{tabular}

Due to rounding, figures do not necessarily add up to totals

* For all values of 10000 or lower the sample size is too small for reliable estimates

- No respondents

** Population as per mid-year estimates, June 2006 


\section{Population}

Table 1.3 - Rural population by province and sex of household head **

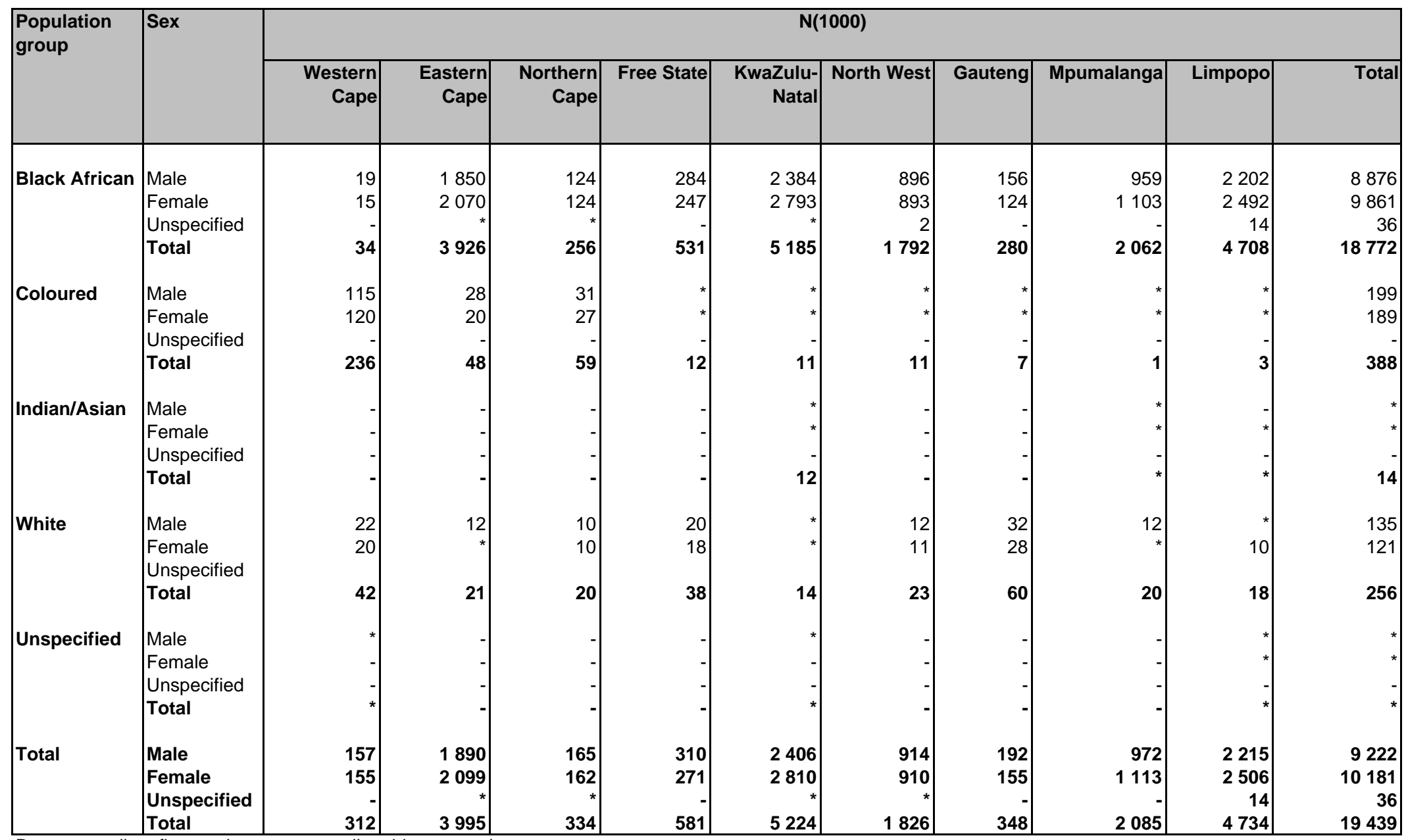

Due to rounding, figures do not necessarily add up to totals

* For all values of 10000 or lower the sample size is too small for reliable estimates

- No respondents

** Population as per mid-year estimates, June 2006 


\section{Expenditure}

Table 2.1 - Percentage distribution of annual household consumption expenditure by main expenditure group and population group of household head

\begin{tabular}{|c|c|c|c|c|c|c|}
\hline & Black African & Coloured & Indian/Asian & White & Unspecified & Total \\
\hline Number of households in sample & 16110 & 2691 & 348 & 1974 & 21 & 21144 \\
\hline Number of households in population & 9566382 & 965778 & 310652 & 1596888 & 17881 & 12457581 \\
\hline Average household size & 4,2 & 4,3 & 3,9 & 2,7 & 2,9 & 3,8 \\
\hline Main expenditure group & \multicolumn{6}{|c|}{ Percentage (\%) } \\
\hline Food and non-alcoholic beverages & 21,4 & 18,6 & 9,7 & 7,7 & 14,6 & 14,4 \\
\hline Alcoholic beverages and tobacco & 1,4 & 2,3 & 0,8 & 0,8 & 1,4 & 1,2 \\
\hline Clothing and footwear & 7,4 & 6,0 & 4,4 & 2,6 & 3,7 & 5,0 \\
\hline Housing, water, electricity, gas and other fuels & 17,9 & 24,1 & 26,7 & 28,4 & 29,6 & 23,6 \\
\hline Furnishings, household equipment and routine maintenance of the dwelling & 8,1 & 5,4 & 5,9 & 6,2 & 6,0 & 6,9 \\
\hline Health & 1,5 & 1,2 & 1,5 & 1,9 & 1,2 & 1,7 \\
\hline Transport & 17,5 & 17,7 & 24,5 & 22,1 & 11,4 & 19,9 \\
\hline Communication & 3,3 & 3,8 & 3,9 & 3,6 & 5,4 & 3,5 \\
\hline Recreation and culture & 3,5 & 4,7 & 5,3 & 5,5 & 4,6 & 4,6 \\
\hline Education & 2,7 & 1,9 & 2,2 & 2,3 & 2,1 & 2,4 \\
\hline Restaurants and hotels & 2,3 & 1,9 & 2,0 & 2,2 & 1,2 & 2,2 \\
\hline Miscellaneous goods and services & 12,8 & 12,0 & 12,9 & 16,5 & 18,4 & 14,4 \\
\hline Other unclassified expenses & 0,2 & 0,5 & 0,3 & 0,3 & 0,5 & 0,3 \\
\hline Total & 100,0 & 100,0 & 100,0 & 100,0 & 100,0 & 100,0 \\
\hline
\end{tabular}

Due to rounding, figures do not necessarily add up to totals 


\section{Expenditure}

Table 2.2 - Percentage distribution of annual consumption expenditure by secondary expenditure group and population group of household head

\begin{tabular}{|c|c|c|c|c|c|c|}
\hline & Black African & Coloured & Indian/Asian & White & Unspecified & Total \\
\hline Number of households in sample & 16110 & 2691 & 348 & 1974 & 21 & 21144 \\
\hline Number of households in population & 9566382 & 965778 & 310652 & 1596888 & 17881 & 12457581 \\
\hline Average household size & 4,2 & 4,3 & 3,9 & 2,7 & 2,9 & 3,8 \\
\hline Secondary expenditure group & \multicolumn{6}{|c|}{ Percentage (\%) } \\
\hline Food and non-alcoholic beverages & 21,4 & 18,6 & 9,7 & 7,7 & 14,6 & 14,4 \\
\hline Food & 19,0 & 15,2 & 7,8 & 5,7 & 11,0 & 12,2 \\
\hline Non-alcoholic beverages & 1,4 & 1,3 & 0,8 & 0,7 & 1,7 & 1,1 \\
\hline Unspecified food & 1,0 & 2,0 & 1,1 & 1,3 & 1,9 & 1,2 \\
\hline Alcoholic beverages and tobacco & 1,4 & 2,3 & 0,8 & 0,8 & 1,4 & 1,2 \\
\hline Alcoholic beverages & 0,6 & 0,6 & 0,2 & 0,4 & 0,8 & 0,5 \\
\hline Tobacco & 0,7 & 1,8 & 0,6 & 0,4 & 0,5 & 0,7 \\
\hline Clothing and footwear & 7,4 & 6,0 & 4,4 & 2,6 & 3,7 & 5,0 \\
\hline Clothing & 5,2 & 4,2 & 3,2 & 1,9 & 2,3 & 3,5 \\
\hline Footwear & 2,2 & 1,8 & 1,2 & 0,7 & 1,4 & 1,5 \\
\hline Housing, water, electricity, gas and other fuels & 17,9 & 24,1 & 26,7 & 28,4 & 29,6 & 23,6 \\
\hline Actual rentals for housing & 3,3 & 3,8 & 4,3 & 3,7 & 14,4 & 3,6 \\
\hline Imputed rentals for housing & 7,4 & 12,0 & 13,6 & 17,4 & 7,3 & 12,6 \\
\hline Maintenance and repair of the dwelling & 1,2 & 1,7 & 0,7 & 2,4 & 1,1 & 1,7 \\
\hline Water supply and miscellaneous services relating to the dwelling & 2,4 & 3,7 & 6,6 & 3,5 & 4,7 & 3,2 \\
\hline Electricity, gas and other fuels & 3,5 & 2,8 & 1,4 & 1,5 & 2,0 & 2,4 \\
\hline
\end{tabular}




\begin{tabular}{|c|c|c|c|c|c|c|}
\hline & Black African & Coloured & Indian/Asian & White & Unspecified & Total \\
\hline $\begin{array}{l}\text { Furnishings, household equipment and routine maintenance of the } \\
\text { dwelling }\end{array}$ & 8,1 & 5,4 & 5,9 & 6,2 & 6,0 & 6,9 \\
\hline Furniture and furnishings, carpets and other floor covering & 2,2 & 1,0 & 0,6 & 0,9 & 0,3 & 1,4 \\
\hline Household textiles & 2,1 & 1,1 & 0,9 & 0,5 & 0,8 & 1,3 \\
\hline Household appliances & 1,4 & 1,1 & 0,9 & 0,5 & 0,5 & 1,0 \\
\hline Glassware, tableware and household utensils & 0,3 & 0,2 & 0,1 & 0,1 & 0,2 & 0,2 \\
\hline Tools and equipment for house and garden & 0,1 & 0,1 & 0,0 & 0,1 & 0,1 & 0,1 \\
\hline Goods and services for routine household maintenance & 1,9 & 1,9 & 3,3 & 3,9 & 4,3 & 2,9 \\
\hline Health & 1,5 & 1,2 & 1,5 & 1,9 & 1,2 & 1,7 \\
\hline Medical products, appliances and equipment & 0,5 & 0,5 & 0,6 & 0,7 & 0,6 & 0,6 \\
\hline Out-patient services & 0,8 & 0,5 & 0,8 & 0,9 & 0,6 & 0,8 \\
\hline Hospital services & 0,1 & 0,2 & 0,1 & 0,2 & 0,0 & 0,2 \\
\hline Transport & 17,5 & 17,7 & 24,5 & 22,1 & 11,4 & 19,9 \\
\hline Purchase of vehicles & 7,4 & 10,0 & 15,6 & 15,1 & -1 & 11,5 \\
\hline Operation of personal transport equipment & 3,7 & 4,8 & 7,1 & 6,1 & 8,1 & 5,0 \\
\hline Transport services & 6,5 & 2,9 & 1,7 & 0,8 & 3,3 & 3,4 \\
\hline Operational values of other modes of transport & 0,0 & 0,0 & 0,0 & 0,0 & & 0,0 \\
\hline Communication & 3,3 & 3,8 & 3,9 & 3,6 & 5,4 & 3,5 \\
\hline Postal services & 0,0 & 0,0 & 0,1 & 0,1 & 0,1 & 0,1 \\
\hline Telephone and telefax equipment & 0,7 & 0,4 & 0,3 & 0,1 & 0,4 & 0,4 \\
\hline Telephone and telefax services & 2,5 & 3,4 & 3,5 & 3,4 & 5,0 & 3,0 \\
\hline Recreation and culture & 3,5 & 4,7 & 5,3 & 5,5 & 4,6 & 4,6 \\
\hline Audio-visual, photographic and information processing equipment & 1,7 & 1,6 & 1,8 & 1,3 & 1,6 & 1,5 \\
\hline Other major durables for recreation and culture & 0,1 & 0,0 & 0,0 & 0,1 & 0,0 & 0,1 \\
\hline Other recreational items and equipment, garden and pets & 0,2 & 1,0 & 0,9 & 1,3 & 0,9 & 0,8 \\
\hline Recreational and cultural services & 0,8 & 1,2 & 1,1 & 1,7 & 1,2 & 1,3 \\
\hline Newspapers, books and stationery & 0,8 & 0,8 & 0,7 & 0,7 & 0,8 & 0,8 \\
\hline Package holidays & 0,0 & 0,1 & 0,8 & 0,3 & & 0,2 \\
\hline
\end{tabular}




\begin{tabular}{|c|c|c|c|c|c|c|}
\hline & Black African & Coloured & Indian/Asian & White & Unspecified & Total \\
\hline Education & 2,7 & 1,9 & 2,2 & 2,3 & 2,1 & 2,4 \\
\hline Pre-primary and primary education & 0,6 & 0,9 & 0,5 & 0,6 & 0,2 & 0,6 \\
\hline Secondary education & 0,6 & 0,5 & 0,5 & 0,7 & 0,9 & 0,6 \\
\hline Tertiary education & 1,0 & 0,5 & 1,1 & 0,9 & 0,9 & 0,9 \\
\hline Education not definable by level & 0,5 & 0,0 & 0,0 & 0,1 & 0,0 & 0,2 \\
\hline Restaurants and hotels & 2,3 & 1,9 & 2,0 & 2,2 & 1,2 & 2,2 \\
\hline Catering services & 1,8 & 1,3 & 1,0 & 1,1 & 0,7 & 1,4 \\
\hline Accommodation services & 0,5 & 0,6 & 1,0 & 1,2 & 0,5 & 0,8 \\
\hline Miscellaneous goods and services & 12,8 & 12,0 & 12,9 & 16,5 & 18,4 & 14,4 \\
\hline Personal care & 1,5 & 1,4 & 0,9 & 1,0 & 1,3 & 1,2 \\
\hline Personal effects & 0,4 & 0,4 & 0,6 & 0,4 & 0,1 & 0,5 \\
\hline Social protection & 0,3 & 0,3 & 0,2 & 0,2 & - & 0,2 \\
\hline Insurance & 5,0 & 5,9 & 8,0 & 11,3 & 13,1 & 8,1 \\
\hline Financial services n.e.c. & 1,4 & 1,5 & 1,2 & 1,4 & 1,0 & 1,4 \\
\hline Other services n.e.c. & 4,1 & 2,3 & 2,0 & 2,2 & 2,9 & 3,0 \\
\hline Other unclassified expenses & 0,2 & 0,5 & 0,3 & 0,3 & 0,5 & 0,3 \\
\hline Total & 100,0 & 100,0 & 100,0 & 100,0 & 100,0 & 100,0 \\
\hline
\end{tabular}

Due to rounding, figures do not necessarily add up to totals

- No expenditure 


\section{Expenditure}

Table 2.3 - Percentage distribution of annual household consumption expenditure by third expenditure group and population group of household head

\begin{tabular}{|c|c|c|c|c|c|c|}
\hline & Black African & Coloured & Indian/ Asian & White & Unspecified & Total \\
\hline Number of households in sample & 16110 & 2691 & 348 & 1974 & 21 & 21144 \\
\hline Number of households in population & 9566382 & 965778 & 310652 & 1596888 & 17881 & 12457581 \\
\hline Average household size & 4,2 & 4,3 & 3,9 & 2,7 & 2,9 & 3,8 \\
\hline Third expenditure group & \multicolumn{6}{|c|}{ Percentage (\%) } \\
\hline Food and non-alcoholic beverages & 21,4 & 18,6 & 9,7 & 7,7 & 14,6 & 14,4 \\
\hline Bread and cereals & 5,5 & 2,9 & 1,7 & 0,9 & 2,4 & 3,0 \\
\hline Meat & 5,4 & 5,6 & 2,2 & 1,8 & 2,3 & 3,6 \\
\hline Fish & 0,7 & 0,7 & 0,4 & 0,3 & 0,4 & 0,5 \\
\hline Milk, cheese and eggs & 1,9 & 1,8 & 1,0 & 0,9 & 1,8 & 1,4 \\
\hline Oils and fats & 0,8 & 0,5 & 0,3 & 0,2 & 0,4 & 0,5 \\
\hline Fruits & 0,4 & 0,3 & 0,2 & 0,3 & 0,6 & 0,4 \\
\hline Food products n.e.c. & 1,1 & 0,8 & 0,6 & 0,3 & 0,7 & 0,7 \\
\hline Coffee, tea and cocoa & 0,3 & 0,4 & 0,1 & 0,2 & 0,4 & 0,3 \\
\hline Mineral waters, soft drinks, fruit and vegetable juices & 1,1 & 0,9 & 0,6 & 0,5 & 1,3 & 0,8 \\
\hline Unspecified food & 1,0 & 2,0 & 1,1 & 1,3 & 1,9 & 1,2 \\
\hline Alcoholic beverages and tobacco & 1,4 & 2,3 & 0,8 & 0,8 & 1,4 & 1,2 \\
\hline Spirits & 0,1 & 0,2 & 0,0 & 0,1 & 0,4 & 0,1 \\
\hline Wine & 0,1 & 0,1 & 0,0 & 0,1 & 0,1 & 0,1 \\
\hline Beer & 0,5 & 0,2 & 0,1 & 0,1 & 0,4 & 0,3 \\
\hline Tobacco & 0,7 & 1,8 & 0,6 & 0,4 & 0,5 & 0,7 \\
\hline
\end{tabular}




\begin{tabular}{|c|c|c|c|c|c|c|}
\hline & Black African & Coloured & Indian/ Asian & White & Unspecified & Total \\
\hline Clothing and footwear & 7,4 & 6,0 & 4,4 & 2,6 & 3,7 & 5,0 \\
\hline Clothing materials & 0,0 & 0,0 & 0,1 & 0,0 & - & 0,0 \\
\hline Garments & 5,0 & 4,1 & 3,0 & 1,8 & 2,2 & 3,4 \\
\hline Other articles of clothing and clothing accessories & 0,1 & 0,1 & 0,1 & 0,1 & 0,1 & 0,1 \\
\hline Cleaning, repair and hire of clothing & 0,0 & 0,0 & 0,0 & 0,0 & - & 0,0 \\
\hline Shoes and other footwear & 2,2 & 1,7 & 1,2 & 0,7 & 1,4 & 1,4 \\
\hline Repair and hire of footwear & 0,0 & 0,0 & 0,0 & 0,0 & - & 0,0 \\
\hline Housing, water, electricity, gas and other fuels & 17,9 & 24,1 & 26,7 & 28,4 & 29,6 & 23,6 \\
\hline Actual rentals paid by tenants & 3,3 & 3,8 & 4,3 & 3,7 & 14,4 & 3,6 \\
\hline Imputed rentals of owner-occupiers & 7,4 & 12,0 & 13,6 & 17,4 & 7,3 & 12,6 \\
\hline Materials for maintenance and repair of the dwelling & 0,6 & 0,4 & 0,3 & 0,8 & 0,0 & 0,7 \\
\hline Service of the maintenance and repair of the dwelling & 0,6 & 1,3 & 0,4 & 1,6 & 1,1 & 1,1 \\
\hline Water and electricity & 0,6 & 0,8 & 3,8 & 1,0 & 1,2 & 0,9 \\
\hline Water supply & 0,7 & 0,8 & 0,7 & 0,5 & 0,3 & 0,6 \\
\hline Refuse collection & 0,2 & 0,3 & 0,2 & 0,1 & 0,6 & 0,2 \\
\hline Sewerage collection & 0,3 & 0,4 & 0,2 & 0,2 & 0,4 & 0,2 \\
\hline Other services relating to the dwelling & 0,7 & 1,5 & 1,9 & 1,6 & 2,2 & 1,2 \\
\hline Electricity & 2,2 & 2,6 & 1,4 & 1,4 & 1,9 & 1,8 \\
\hline Gas & 0,1 & 0,1 & 0,0 & 0,0 & - & 0,1 \\
\hline Liquid fuels & 0,7 & 0,1 & 0,0 & 0,0 & 0,1 & 0,3 \\
\hline Solid fuels & 0,6 & 0,1 & 0,0 & 0,0 & 0,0 & 0,3 \\
\hline $\begin{array}{l}\text { Furnishings, household equipment and routine maintenance of the } \\
\text { dwelling }\end{array}$ & 8,1 & 5,4 & 5,9 & 6,2 & 6,0 & 6,9 \\
\hline Furniture and furnishings & 2,0 & 0,8 & 0,5 & 0,8 & 0,2 & 1,3 \\
\hline Carpets and other floor covering & 0,2 & 0,2 & 0,1 & 0,1 & 0,1 & 0,1 \\
\hline Repair of furniture, furnishings and floor covering & 0,0 & 0,0 & 0,0 & 0,0 & - & 0,0 \\
\hline Household textiles & 2,1 & 1,1 & 0,9 & 0,5 & 0,8 & 1,3 \\
\hline Major household appliances & 1,2 & 0,9 & 0,7 & 0,4 & 0,4 & 0,8 \\
\hline Small electrical household appliances & 0,2 & 0,2 & 0,2 & 0,1 & 0,1 & 0,1 \\
\hline
\end{tabular}




\begin{tabular}{|c|c|c|c|c|c|c|}
\hline & Black African & Coloured & Indian/ Asian & White & Unspecified & Total \\
\hline Repair of household appliances & 0,0 & 0,0 & 0,0 & 0,0 & 0,0 & 0,0 \\
\hline Glassware, tableware and household utensils & 0,3 & 0,2 & 0,1 & 0,1 & 0,2 & 0,2 \\
\hline Major tools and equipment & 0,0 & 0,0 & 0,0 & 0,1 & 0,0 & 0,0 \\
\hline Small tools and miscellaneous accessories & 0,1 & 0,1 & 0,0 & 0,1 & 0,0 & 0,1 \\
\hline Non-durable household goods & 1,2 & 0,8 & 0,4 & 0,5 & 0,7 & 0,8 \\
\hline Domestic services and household arcticles & 0,7 & 1,1 & 2,8 & 3,4 & 3,5 & 2,1 \\
\hline Health & 1,5 & 1,2 & 1,5 & 1,9 & 1,2 & 1,7 \\
\hline Medical products, appliances and equipment & 0,5 & 0,5 & 0,6 & 0,7 & 0,6 & 0,6 \\
\hline Out-patient services & 0,8 & 0,5 & 0,8 & 0,9 & 0,6 & 0,8 \\
\hline Hospital services & 0,1 & 0,2 & 0,1 & 0,2 & 0,0 & 0,2 \\
\hline Transport & 17,5 & 17,7 & 24,5 & 22,1 & 11,4 & 19,9 \\
\hline Motor cars & 7,3 & 9,9 & 15,6 & 14,9 & - & 11,4 \\
\hline Motorcycles & 0,0 & 0,0 & - & 0,1 & - & 0,1 \\
\hline Bicycles & 0,0 & 0,1 & - & 0,0 & - & 0,0 \\
\hline Animal-drawn vehicles & 0,0 & 0,0 & - & 0,0 & - & 0,0 \\
\hline Spare parts and accessories & 0,5 & 0,6 & 0,7 & 0,7 & 0,8 & 0,6 \\
\hline Fuels and lubricants & 2,4 & 3,4 & 5,3 & 4,3 & 5,8 & 3,5 \\
\hline Maintenance and repair of personal transport equipment & 0,3 & 0,4 & 0,6 & 0,6 & 0,5 & 0,5 \\
\hline Other services in respect of personal transport equipment & 0,5 & 0,4 & 0,6 & 0,5 & 1,0 & 0,5 \\
\hline Passenger transport by rail & 0,3 & 0,2 & 0,0 & 0,0 & 0,0 & 0,1 \\
\hline Passenger transport by road & 6,0 & 2,7 & 1,3 & 0,3 & 0,9 & 2,9 \\
\hline
\end{tabular}




\begin{tabular}{|c|c|c|c|c|c|c|}
\hline & Black African & Coloured & Indian/ Asian & White & Unspecified & Total \\
\hline Passenger transport by air & 0,1 & 0,0 & 0,3 & 0,5 & 2,4 & 0,3 \\
\hline Passenger transport by sea and inland waterway & 0,0 & - & 0,0 & 0,0 & - & 0,0 \\
\hline Other puchased transport services & 0,0 & 0,0 & 0,0 & 0,0 & - & 0,0 \\
\hline Cost for other modes of transport & 0,0 & 0,0 & 0,0 & 0,0 & - & 0,0 \\
\hline Communication & 3,3 & 3,8 & 3,9 & 3,6 & 5,4 & 3,5 \\
\hline Postal services & 0,0 & 0,0 & 0,1 & 0,1 & 0,1 & 0,1 \\
\hline Telephone and telefax equipment & 0,7 & 0,4 & 0,3 & 0,1 & 0,4 & 0,4 \\
\hline Telephone and telefax services & 2,5 & 3,4 & 3,5 & 3,4 & 5,0 & 3,0 \\
\hline Recreation and culture & 3,5 & 4,7 & 5,3 & 5,5 & 4,6 & 4,6 \\
\hline Audio-visual, photographic and information processing equipment & 1,7 & 1,6 & 1,8 & 1,3 & 1,6 & 1,5 \\
\hline Other major durables for recreation and culture & 0,1 & 0,0 & 0,0 & 0,1 & 0,0 & 0,1 \\
\hline Other recreational items and equipment, garden and pets & 0,2 & 1,0 & 0,9 & 1,3 & 0,9 & 0,8 \\
\hline Recreational and cultural services & 0,8 & 1,2 & 1,1 & 1,7 & 1,2 & 1,3 \\
\hline Newspapers, books and stationery & 0,8 & 0,8 & 0,7 & 0,7 & 0,8 & 0,8 \\
\hline Package holidays & 0,0 & 0,1 & 0,8 & 0,3 & - & 0,2 \\
\hline Education & 2,7 & 1,9 & 2,2 & 2,3 & 2,1 & 2,4 \\
\hline Pre-primary and primary education & 0,6 & 0,9 & 0,5 & 0,6 & 0,2 & 0,6 \\
\hline Secondary education & 0,6 & 0,5 & 0,5 & 0,7 & 0,9 & 0,6 \\
\hline Tertiary education & 1,0 & 0,5 & 1,1 & 0,9 & 0,9 & 0,9 \\
\hline Education not definable by level & 0,5 & 0,0 & 0,0 & 0,1 & 0,0 & 0,2 \\
\hline Restaurants and hotels & 2,3 & 1,9 & 2,0 & 2,2 & 1,2 & 2,2 \\
\hline Beverages in restaurants, cafes, canteens and the like & 0,7 & 0,3 & 0,0 & 0,1 & 0,1 & 0,4 \\
\hline Meals in restaurants, cafes, canteens and the like & 1,1 & 1,0 & 1,0 & 0,9 & 0,6 & 1,0 \\
\hline Accommodation services & 0,5 & 0,6 & 1,0 & 1,2 & 0,5 & 0,8 \\
\hline
\end{tabular}




\begin{tabular}{|c|c|c|c|c|c|c|}
\hline & Black African & Coloured & Indian/ Asian/ & White & Unspecified & Total \\
\hline Miscellaneous goods and services & 12,8 & 12,0 & 12,9 & 16,5 & 18,4 & 14,4 \\
\hline Hairdressing salons and personal grooming establishments & 0,0 & 0,1 & 0,1 & 0,1 & 0,0 & 0,1 \\
\hline Electrical appliances for personal care & 0,0 & 0,0 & 0,0 & 0,0 & & 0,0 \\
\hline Other appliances, articles and products for personal care & 1,5 & 1,3 & 0,9 & 0,9 & 1,3 & 1,2 \\
\hline Jewellery, clocks and watches & 0,2 & 0,3 & 0,4 & 0,3 & 0,0 & 0,2 \\
\hline Other personal effects & 0,2 & 0,2 & 0,2 & 0,2 & 0,1 & 0,2 \\
\hline Social protection services & 0,3 & 0,3 & 0,2 & 0,2 & - & 0,2 \\
\hline Insurance connected with dwelling & 0,6 & 1,3 & 3,2 & 4,9 & 3,1 & 2,8 \\
\hline Insurance connected with health & 2,1 & 3,0 & 3,2 & 4,7 & 7,5 & 3,4 \\
\hline Insurance connected with transport & 0,3 & 0,5 & 1,2 & 1,3 & 2,1 & 0,8 \\
\hline Other insurance & 2,0 & 1,1 & 0,5 & 0,3 & 0,4 & 1,1 \\
\hline Financial services n.e.c. & 1,4 & 1,5 & 1,2 & 1,4 & 1,0 & 1,4 \\
\hline Other services & 4,1 & 2,3 & 2,0 & 2,2 & 2,9 & 3,0 \\
\hline Other unclassified expenses & 0,2 & 0,5 & 0,3 & 0,3 & 0,5 & 0,3 \\
\hline Total & 100,0 & 100,0 & 100,0 & 100,0 & 100,0 & 100,0 \\
\hline
\end{tabular}

Due to rounding, figures do not necessarily add up to totals

- No expenditure 


\section{Expenditure}

Table 2.4 - Percentage distribution of annual household consumption expenditure by main expenditure group and sex of household head

\begin{tabular}{|c|c|c|c|}
\hline & Male & Female & *Total \\
\hline Number of households in sample & 11815 & 9310 & 21144 \\
\hline Number of households in population & 7607409 & 4841472 & 12457580 \\
\hline Average household size & 3,8 & 4,3 & 3,8 \\
\hline Main expenditure group & \multicolumn{3}{|c|}{ Percentage (\%) } \\
\hline Food and non-alcoholic beverages & 12,8 & 18,9 & 14,4 \\
\hline Alcoholic beverages and tobacco & 1,3 & 0,9 & 1,2 \\
\hline Clothing and footwear & 4,5 & 6,2 & 5,0 \\
\hline Housing, water, electricity, gas and other fuels & 23,9 & 22,8 & 23,6 \\
\hline Furnishings, household equipment and routine maintenance of the dwelling & 6,6 & 7,6 & 6,9 \\
\hline Health & 1,7 & 1,6 & 1,7 \\
\hline Transport & 21,3 & 16,3 & 19,9 \\
\hline Communication & 3,6 & 3,4 & 3,5 \\
\hline Recreation and culture & 4,9 & 3,9 & 4,6 \\
\hline Education & 2,4 & 2,6 & 2,4 \\
\hline Restaurants and hotels & 2,4 & 1,8 & 2,2 \\
\hline Miscellaneous goods and services & 14,6 & 14,0 & 14,4 \\
\hline Other unclassified expenses & 0,3 & 0,3 & 0,3 \\
\hline Total & 100,0 & 100,0 & 100,0 \\
\hline
\end{tabular}

*Total includes households with unspecified sex of household head

Due to rounding, figures do not necessarily add up to totals 


\section{Expenditure}

Table 2.5 - Percentage distribution of annual household consumption expenditure by secondary expenditure group and sex of household head

\begin{tabular}{|c|c|c|c|}
\hline & Male & Female & *Total \\
\hline Number of households in sample & 11815 & 9310 & 21144 \\
\hline Number of households in population & 7607409 & 4841472 & 12457580 \\
\hline Average household size & 3,8 & 4,3 & 3,8 \\
\hline Secondary expenditure group & \multicolumn{3}{|c|}{ Percentage (\%) } \\
\hline Food and non-alcoholic beverages & 12,8 & 18,9 & 14,4 \\
\hline Food & 10,6 & 16,5 & 12,2 \\
\hline Non-alcoholic beverages & 1,0 & 1,2 & 1,1 \\
\hline Unspecified food & 1,2 & 1,2 & 1,2 \\
\hline Alcoholic beverages and tobacco & 1,3 & 0,9 & 1,2 \\
\hline Alcoholic beverages & 0,5 & 0,3 & 0,5 \\
\hline Tobacco & 0,7 & 0,6 & 0,7 \\
\hline Clothing and footwear & 4,5 & 6,2 & 5,0 \\
\hline Clothing & 3,2 & 4,3 & 3,5 \\
\hline Footwear & 1,3 & 1,8 & 1,5 \\
\hline Housing, water, electricity, gas and other fuels & 23,9 & 22,8 & 23,6 \\
\hline Actual rentals for housing & 3,6 & 3,6 & 3,6 \\
\hline Imputed rentals for housing & 13,1 & 11,4 & 12,6 \\
\hline Maintenance and repair of the dwelling & 1,9 & 1,3 & 1,7 \\
\hline Water supply and miscellaneous services relating to the dwelling & 3,2 & 3,3 & 3,2 \\
\hline Electricity, gas and other fuels & 2,2 & 3,2 & 2,4 \\
\hline
\end{tabular}




\begin{tabular}{|c|c|c|c|}
\hline & Male & Female & *Total \\
\hline $\begin{array}{l}\text { Furnishings, household equipment and routine maintenance of the } \\
\text { dwelling }\end{array}$ & 6,6 & 7,6 & 6,9 \\
\hline Furniture and furnishings, carpets and other floor covering & 1,3 & 1,8 & 1,5 \\
\hline Household textiles & 1,1 & 1,7 & 1,3 \\
\hline Household appliances & 0,9 & 1,2 & 1,0 \\
\hline Glassware, tableware and household utensils & 0,2 & 0,3 & 0,2 \\
\hline Tools and equipment for house and garden & 0,1 & 0,1 & 0,1 \\
\hline Goods and services for routine household maintenance & 3,0 & 2,6 & 2,9 \\
\hline Health & 1,7 & 1,6 & 1,7 \\
\hline Medical products, appliances and equipment & 0,6 & 0,6 & 0,6 \\
\hline Out-patient services & 0,9 & 0,8 & 0,9 \\
\hline Hospital services & 0,2 & 0,1 & 0,2 \\
\hline Transport & 21,3 & 16,3 & 19,9 \\
\hline Purchase of vehicles & 12,6 & 8,4 & 11,5 \\
\hline Operation of personal transport equipment & 5,6 & 3,4 & 5,0 \\
\hline Transport services & 3,0 & 4,5 & 3,4 \\
\hline Operational values of other modes of transport & 0,0 & 0,0 & 0,0 \\
\hline Communication & 3,6 & 3,4 & 3,5 \\
\hline Postal services & 0,1 & 0,0 & 0,1 \\
\hline Telephone and telefax equipment & 0,4 & 0,6 & 0,4 \\
\hline Telephone and telefax services & 3,1 & 2,8 & 3,0 \\
\hline Recreation and culture & 4,9 & 3,9 & 4,6 \\
\hline Audio-visual, photographic and information processing equipment & 1,5 & 1,4 & 1,5 \\
\hline Other major durables for recreation and culture & 0,1 & 0,1 & 0,1 \\
\hline Other recreational items and equipment, garden and pets & 0,9 & 0,6 & 0,8 \\
\hline Recreational and cultural services & 1,4 & 0,9 & 1,3 \\
\hline Newspapers, books and stationery & 0,8 & 0,8 & 0,8 \\
\hline Package holidays & 0,2 & 0,1 & 0,2 \\
\hline
\end{tabular}




\begin{tabular}{|c|c|c|c|}
\hline & Male & Female & *Total \\
\hline Education & 2,4 & 2,6 & 2,4 \\
\hline Pre-primary and primary education & 0,6 & 0,6 & 0,6 \\
\hline Secondary education & 0,6 & 0,7 & 0,6 \\
\hline Tertiary education & 1,0 & 0,9 & 0,9 \\
\hline Education not definable by level & 0,2 & 0,5 & 0,2 \\
\hline Restaurants and hotels & 2,4 & 1,8 & 2,2 \\
\hline Catering services & 1,5 & 1,2 & 1,4 \\
\hline Accommodation services & 0,9 & 0,6 & 0,8 \\
\hline Miscellaneous goods and services & 14,6 & 14,0 & 14,4 \\
\hline Personal care & 1,1 & 1,6 & 1,2 \\
\hline Personal effects & 0,5 & 0,5 & 0,5 \\
\hline Social protection & 0,2 & 0,2 & 0,2 \\
\hline Insurance & 8,6 & 6,8 & 8,1 \\
\hline Financial services n.e.c. & 1,5 & 1,3 & 1,4 \\
\hline Other services n.e.c. & 2,8 & 3,6 & 3,0 \\
\hline Other unclassified expenses & 0,3 & 0,3 & 0,3 \\
\hline Total & 100,0 & 100,0 & 100,0 \\
\hline
\end{tabular}

Due to rounding, figures do not necessarily add up to totals 


\section{Expenditure}

Table 2.6 - Percentage distribution of annual household consumption expenditure by third expenditure group and sex of household head

\begin{tabular}{|c|c|c|c|}
\hline & Male & Female & *Total \\
\hline Households in sample & 11815 & 9310 & 21144 \\
\hline Households in population & 7607409 & 4841472 & 12457580 \\
\hline Average of household size & 3,8 & 4,3 & 3,8 \\
\hline Third expenditure group & \multicolumn{3}{|c|}{ Percentage (\%) } \\
\hline Food and non-alcoholic beverages & 12,8 & 18,9 & 14,4 \\
\hline Bread and cereals & 2,4 & 4,6 & 3,0 \\
\hline Meat & 3,3 & 4,5 & 3,6 \\
\hline Fish & 0,5 & 0,5 & 0,5 \\
\hline Milk, cheese and eggs & 1,3 & 1,7 & 1,4 \\
\hline Oils and fats & 0,4 & 0,7 & 0,5 \\
\hline Fruits & 0,3 & 0,5 & 0,4 \\
\hline Vegetables & 1,2 & 2,0 & 1,4 \\
\hline Sugar, jam, honey, chocolate and confectionery & 0,6 & 1,1 & 0,7 \\
\hline Food products n.e.c. & 0,6 & 0,9 & 0,7 \\
\hline Coffee, tea and cocoa & 0,2 & 0,3 & 0,3 \\
\hline Mineral waters, soft drinks, fruit and vegetable juices & 0,8 & 0,9 & 0,8 \\
\hline Unspecified food & 1,2 & 1,2 & 1,2 \\
\hline Alcoholic beverages and tobacco & 1,3 & 0,9 & 1,2 \\
\hline Spirits & 0,2 & 0,1 & 0,1 \\
\hline Wine & 0,1 & 0,1 & 0,1 \\
\hline Beer & 0,3 & 0,2 & 0,3 \\
\hline Tobacco & 0,7 & 0,6 & 0,7 \\
\hline
\end{tabular}




\begin{tabular}{|c|c|c|c|}
\hline & Male & Female & *Total \\
\hline Clothing and footwear & 4,5 & 6,2 & 5,0 \\
\hline Clothing materials & 0,0 & 0,1 & 0,0 \\
\hline Garments & 3,1 & 4,2 & 3,4 \\
\hline Other articles of clothing and clothing accessories & 0,1 & 0,1 & 0,1 \\
\hline Cleaning, repair and hire of clothing & 0,0 & 0,0 & 0,0 \\
\hline Shoes and other footwear & 1,3 & 1,8 & 1,4 \\
\hline Repair and hire of footwear & 0,0 & 0,0 & 0,0 \\
\hline Housing, water, electricity, gas and other fuels & 23,9 & 22,8 & 23,6 \\
\hline Actual rentals paid by tenants & 3,6 & 3,6 & 3,6 \\
\hline Imputed rentals of owner-occupiers & 13,1 & 11,4 & 12,6 \\
\hline Materials for maintenance and repair of the dwelling & 0,7 & 0,6 & 0,7 \\
\hline Service of the maintenance and repair of the dwelling & 1,2 & 0,7 & 1,1 \\
\hline Water and electricity & 1,0 & 0,8 & 0,9 \\
\hline Water supply & 0,6 & 0,8 & 0,6 \\
\hline Refuse collection & 0,2 & 0,2 & 0,2 \\
\hline Sewerage collection & 0,2 & 0,3 & 0,2 \\
\hline Other services relating to the dwelling & 1,2 & 1,2 & 1,2 \\
\hline Electricity & 1,7 & 2,1 & 1,8 \\
\hline Gas & 0,1 & 0,1 & 0,1 \\
\hline Liquid fuels & 0,2 & 0,5 & 0,3 \\
\hline Solid fuels & 0,2 & 0,5 & 0,3 \\
\hline Furnishings, household equipment and routine maintenance of the dwelling & 6,6 & 7,6 & 6,9 \\
\hline Furniture and furnishings & 1,2 & 1,6 & 1,3 \\
\hline Carpets and other floor covering & 0,2 & 0,2 & 0,2 \\
\hline Repair of furniture, furnishings and floor covering & 0,0 & 0,0 & 0,0 \\
\hline Household textiles & 1,1 & 1,7 & 1,3 \\
\hline Major household appliances & 0,8 & 1,0 & 0,8 \\
\hline Small electrical household appliances & 0,1 & 0,2 & 0,1 \\
\hline
\end{tabular}




\begin{tabular}{|c|c|c|c|}
\hline & Male & Female & ${ }^{*}$ Total \\
\hline Repair of household appliances & 0,0 & 0,0 & 0,0 \\
\hline Glassware, tableware and household utensils & 0,2 & 0,3 & 0,2 \\
\hline Major tools and equipment & 0,0 & 0,0 & 0,0 \\
\hline Small tools and miscellaneous accessories & 0,1 & 0,1 & 0,1 \\
\hline Non-durable household goods & 0,7 & 1,1 & 0,8 \\
\hline Domestic services and household arcticles & 2,3 & 1,5 & 2,1 \\
\hline Health & 1,7 & 1,6 & 1,7 \\
\hline Medical products, appliances and equipment & 0,6 & 0,6 & 0,6 \\
\hline Out-patient services & 0,9 & 0,8 & 0,9 \\
\hline Hospital services & 0,2 & 0,1 & 0,2 \\
\hline Transport & 21,3 & 16,3 & 19,9 \\
\hline Motor cars & 12,5 & 8,3 & 11,4 \\
\hline Motorcycles & 0,1 & 0,0 & 0,1 \\
\hline Bicycles & 0,0 & 0,0 & 0,0 \\
\hline Animal-drawn vehicles & 0,0 & 0,0 & 0,0 \\
\hline Spare parts and accessories & 0,7 & 0,4 & 0,6 \\
\hline Fuels and lubricants & 3,9 & 2,3 & 3,5 \\
\hline Maintenance and repair of personal transport equipment & 0,5 & 0,3 & 0,5 \\
\hline Other services in respect of personal transport equipment & 0,6 & 0,4 & 0,5 \\
\hline Passenger transport by rail & 0,2 & 0,2 & 0,2 \\
\hline Passenger transport by road & 2,5 & 4,1 & 2,9 \\
\hline Passenger transport by air & 0,3 & 0,2 & 0,3 \\
\hline Passenger transport by sea and inland waterway & 0,0 & 0,0 & 0,0 \\
\hline Other puchased transport services & 0,0 & 0,0 & 0,0 \\
\hline Cost for other modes of transport & 0,0 & 0,0 & 0,0 \\
\hline
\end{tabular}




\begin{tabular}{|c|c|c|c|}
\hline & Male & Female & ${ }^{*}$ Total \\
\hline Communication & 3,6 & 3,4 & 3,5 \\
\hline Postal services & 0,1 & 0,0 & 0,1 \\
\hline Telephone and telefax equipment & 0,4 & 0,6 & 0,4 \\
\hline Telephone and telefax services & 3,1 & 2,8 & 3,0 \\
\hline Recreation and culture & 4,9 & 3,9 & 4,6 \\
\hline Audio-visual, photographic and information processing equipment & 1,5 & 1,4 & 1,5 \\
\hline Other major durables for recreation and culture & 0,1 & 0,1 & 0,1 \\
\hline Other recreational items and equipment, garden and pets & 0,9 & 0,6 & 0,8 \\
\hline Recreational and cultural services & 1,4 & 0,9 & 1,3 \\
\hline Newspapers, books and stationery & 0,8 & 0,8 & 0,8 \\
\hline Package holidays & 0,2 & 0,1 & 0,2 \\
\hline Education & 2,4 & 2,6 & 2,4 \\
\hline Pre-primary and primary education & 0,6 & 0,6 & 0,6 \\
\hline Secondary education & 0,6 & 0,7 & 0,6 \\
\hline Tertiary education & 1,0 & 0,9 & 0,9 \\
\hline Education not definable by level & 0,2 & 0,5 & 0,2 \\
\hline Restaurants and hotels & 2,4 & 1,8 & 2,2 \\
\hline Beverages in restaurants, cafes, canteens and the like & 0,4 & 0,3 & 0,4 \\
\hline Meals in restaurants, cafes, canteens and the like & 1,0 & 0,9 & 1,0 \\
\hline Accommodation services & 0,9 & 0,6 & 0,8 \\
\hline
\end{tabular}




\begin{tabular}{|c|c|c|c|}
\hline & Male & Female & *Total \\
\hline Miscellaneous goods and services & 14,6 & 14,0 & 14,4 \\
\hline Hairdressing salons and personal grooming establishments & 0,1 & 0,1 & 0,1 \\
\hline Electrical appliances for personal care & 0,0 & 0,0 & 0,0 \\
\hline Other appliances, articles and products for personal care & 1,0 & 1,5 & 1,2 \\
\hline Jewellery, clocks and watches & 0,3 & 0,2 & 0,3 \\
\hline Other personal effects & 0,2 & 0,3 & 0,2 \\
\hline Social protection services & 0,2 & 0,2 & 0,2 \\
\hline Insurance connected with the dwelling & 2,9 & 2,4 & 2,8 \\
\hline Insurance connected with health & 3,8 & 2,3 & 3,4 \\
\hline Insurance connected with transport & 0,9 & 0,7 & 0,8 \\
\hline Other insurance & 0,9 & 1,5 & 1,1 \\
\hline Financial services n.e.c. & 1,5 & 1,3 & 1,4 \\
\hline Other services & 2,8 & 3,6 & 3,0 \\
\hline Other unclassified expenses & 0,3 & 0,3 & 0,3 \\
\hline Total & 100,0 & 100,0 & 100,0 \\
\hline
\end{tabular}

*Total includes households with unspecified sex of household head

Due to rounding, figures do not necessarily add up to totals 


\section{Expenditure}

Table 2.7 - Percentage distribution of annual household consumption expenditure by main expenditure group and type of settlement

\begin{tabular}{|c|c|c|c|}
\hline & Urban & Rural & Total \\
\hline Main expenditure group & \multicolumn{3}{|c|}{ Percentage (\%) } \\
\hline Food and non-alcoholic beverages & 12,5 & 24,8 & 14,4 \\
\hline Alcoholic beverages and tobacco & 1,1 & 1,2 & 1,2 \\
\hline Clothing and footwear & 4,6 & 7,1 & 5,0 \\
\hline Housing, water, electricity, gas and other fuels & 25,0 & 16,3 & 23,6 \\
\hline $\begin{array}{l}\text { Furnishings, household equipment and routine maintenance of the } \\
\text { dwelling }\end{array}$ & 6,5 & 8,8 & 6,9 \\
\hline Health & 1,6 & 1,8 & 1,7 \\
\hline Communication & 3,6 & 3,2 & 3,5 \\
\hline Recreation and culture & 4,9 & 3,1 & 4,6 \\
\hline Education & 2,3 & 3,0 & 2,4 \\
\hline Restaurants and hotels & 2,3 & 1,9 & 2,2 \\
\hline Miscellaneous goods and services & 14,6 & 13,3 & 14,4 \\
\hline Other unclassified expenses & 0,3 & 0,2 & 0,3 \\
\hline Total & 100,0 & 100,0 & 100,0 \\
\hline
\end{tabular}




\section{Expenditure}

Table 2.8 - Percentage distribution of annual household consumption expenditure by secondary expenditure group and type of settlement

\begin{tabular}{|c|c|c|c|}
\hline Expenditure group & Urban & Rural & Total \\
\hline Number of households in sample & 11859 & 9285 & 21144 \\
\hline Number of households in population & 8112493 & 4345088 & 12457581 \\
\hline Secondary expenditure group & \multicolumn{3}{|c|}{ Percentage (\%) } \\
\hline Food and non-alcoholic beverages & 12,5 & 24,8 & 14,4 \\
\hline Food & 10,2 & 22,4 & 12,2 \\
\hline Non-alcoholic beverages & 1,0 & 1,4 & 1,1 \\
\hline Unspecified food & 1,3 & 1,0 & 1,2 \\
\hline Alcoholic beverages and tobacco & 1,1 & 1,2 & 1,2 \\
\hline Alcoholic beverages & 0,5 & 0,5 & 0,5 \\
\hline Tobacco & 0,7 & 0,7 & 0,7 \\
\hline Clothing and footwear & 4,6 & 7,1 & 5,0 \\
\hline Clothing & 3,2 & 5,0 & 3,5 \\
\hline Footwear & 1,3 & 2,1 & 1,5 \\
\hline Housing, water, electricity, gas and other fuels & 25,0 & 16,3 & 23,6 \\
\hline Actual rentals for housing & 3,9 & 2,2 & 3,6 \\
\hline Imputed rentals for housing & 13,5 & 7,8 & 12,6 \\
\hline Maintenance and repair of the dwelling & 1,9 & 1,0 & 1,7 \\
\hline Water supply and miscellaneous services relating to the dwelling & 3,7 & 0,8 & 3,2 \\
\hline Electricity, gas and other fuels & 2,0 & 4,6 & 2,4 \\
\hline
\end{tabular}




\begin{tabular}{|c|c|c|c|}
\hline Expenditure group & Urban & Rural & Total \\
\hline $\begin{array}{l}\text { Furnishings, household equipment and routine maintenance of the } \\
\text { dwelling }\end{array}$ & 6,5 & 8,8 & 6,9 \\
\hline Furniture and furnishings, carpets and other floor covering & 1,3 & 2,1 & 1,5 \\
\hline Household textiles & 1,1 & 2,3 & 1,3 \\
\hline Household appliances & 0,9 & 1,4 & 1,0 \\
\hline Glassware, tableware and household utensils & 0,2 & 0,3 & 0,2 \\
\hline Tools and equipment for house and garden & 0,1 & 0,2 & 0,1 \\
\hline Goods and services for routine household maintenance & 2,9 & 2,6 & 2,9 \\
\hline Health & 1,6 & 1,8 & 1,7 \\
\hline Medical products, appliances and equipment & 0,6 & 0,6 & 0,6 \\
\hline Out-patient services & 0,8 & 1,1 & 0,9 \\
\hline Hospital services & 0,2 & 0,1 & 0,2 \\
\hline Transport & 20,8 & 15,3 & 19,9 \\
\hline Purchase of vehicles & 12,4 & 6,4 & 11,5 \\
\hline Operation of personal transport equipment & 5,3 & 3,4 & 5,0 \\
\hline Transport services & 3,0 & 5,5 & 3,4 \\
\hline Operational values of other modes of transport & 0,0 & 0,0 & 0,0 \\
\hline Communication & 3,6 & 3,2 & 3,5 \\
\hline Postal services & 0,1 & 0,1 & 0,1 \\
\hline Telephone and telefax equipment & 0,4 & 0,7 & 0,4 \\
\hline Telephone and telefax services & 3,2 & 2,4 & 3,0 \\
\hline Recreation and culture & 4,9 & 3,1 & 4,6 \\
\hline Audio-visual, photographic and information processing equipment & 1,5 & 1,4 & 1,5 \\
\hline Other major durables for recreation and culture & 0,1 & 0,1 & 0,1 \\
\hline Other recreational items and equipment, garden and pets & 0,9 & 0,4 & 0,8 \\
\hline Recreational and cultural services & 1,4 & 0,6 & 1,3 \\
\hline Newspapers, books and stationery & 0,8 & 0,6 & 0,8 \\
\hline Package holidays & 0,2 & 0,0 & 0,2 \\
\hline
\end{tabular}




\begin{tabular}{|c|c|c|c|}
\hline Expenditure group & Urban & Rural & Total \\
\hline Education & 2,3 & 3,0 & 2,4 \\
\hline Pre-primary and primary education & 0,6 & 0,6 & 0,6 \\
\hline Secondary education & 0,6 & 0,8 & 0,6 \\
\hline Tertiary education & 1,0 & 0,8 & 0,9 \\
\hline Education not definable by level & 0,1 & 0,8 & 0,2 \\
\hline Restaurants and hotels & 2,3 & 1,9 & 2,2 \\
\hline Catering services & 1,4 & 1,3 & 1,4 \\
\hline Accommodation services & 0,9 & 0,6 & 0,8 \\
\hline Miscellaneous goods and services & 14,6 & 13,3 & 14,4 \\
\hline Personal care & 1,2 & 1,3 & 1,2 \\
\hline Personal effects & 0,5 & 0,5 & 0,5 \\
\hline Social protection & 0,2 & 0,1 & 0,2 \\
\hline Insurance & 8,6 & 5,3 & 8,1 \\
\hline Financial services n.e.c. & 1,4 & 1,4 & 1,4 \\
\hline Other services n.e.c. & 2,7 & 4,8 & 3,0 \\
\hline Other unclassified expenses & 0,3 & 0,2 & 0,3 \\
\hline Total & 100,0 & 100,0 & 100,0 \\
\hline
\end{tabular}




\section{Expenditure}

Table 2.9 - Percentage distribution of annual household consumption expenditure by third expenditure group and type of settlement

\begin{tabular}{|c|c|c|c|}
\hline & Urban & Rural & Total \\
\hline Number of households in sample & 11859 & 9285 & 21144 \\
\hline Number of households in population & 8112493 & 4345088 & 12457581 \\
\hline Third expenditure group & \multicolumn{3}{|c|}{ Percentage (\%) } \\
\hline Food and non-alcoholic beverages & 12,5 & 24,8 & 14,4 \\
\hline Bread and cereals & 2,2 & 7,4 & 3,0 \\
\hline Meat & 3,3 & 5,6 & 3,6 \\
\hline Fish & 0,5 & 0,7 & 0,5 \\
\hline Milk, cheese and eggs & 1,3 & 2,0 & 1,4 \\
\hline Oils and fats & 0,4 & 1,0 & 0,5 \\
\hline Fruits & 0,3 & 0,5 & 0,4 \\
\hline Vegetables & 1,1 & 2,7 & 1,4 \\
\hline Sugar, jam, honey, chocolate and confectionery & 0,6 & 1,5 & 0,7 \\
\hline Food products n.e.c. & 0,6 & 1,1 & 0,7 \\
\hline Coffee, tea and cocoa & 0,2 & 0,4 & 0,3 \\
\hline Mineral waters, soft drinks, fruit and vegetable juices & 0,8 & 1,0 & 0,8 \\
\hline Unspecified food & 1,3 & 1,0 & 1,2 \\
\hline Alcoholic beverages and tobacco & 1,1 & 1,2 & 1,2 \\
\hline Spirits & 0,1 & 0,1 & 0,1 \\
\hline Wine & 0,1 & 0,1 & 0,1 \\
\hline Beer & 0,2 & 0,4 & 0,3 \\
\hline Tobacco & 0,7 & 0,7 & 0,7 \\
\hline
\end{tabular}




\begin{tabular}{|c|c|c|c|}
\hline & Urban & Rural & Total \\
\hline Clothing and footwear & 4,6 & 7,1 & 5,0 \\
\hline Clothing materials & 0,0 & 0,1 & 0,0 \\
\hline Garments & 3,1 & 4,8 & 3,4 \\
\hline Other articles of clothing and clothing accessories & 0,1 & 0,1 & 0,1 \\
\hline Cleaning, repair and hire of clothing & 0,0 & 0,0 & 0,0 \\
\hline Shoes and other footwear & 1,3 & 2,1 & 1,4 \\
\hline Repair and hire of footwear & 0,0 & 0,0 & 0,0 \\
\hline Housing, water, electricity, gas and other fuels & 25,0 & 16,3 & 23,6 \\
\hline Actual rentals paid by tenants & 3,9 & 2,2 & 3,6 \\
\hline Imputed rentals of owner-occupiers & 13,5 & 7,8 & 12,6 \\
\hline Materials for maintenance and repair of the dwelling & 0,7 & 0,4 & 0,7 \\
\hline Service of the maintenance and repair of the dwelling & 1,2 & 0,6 & 1,1 \\
\hline Water and electricity & 1,1 & 0,3 & 0,9 \\
\hline Water supply & 0,7 & 0,2 & 0,6 \\
\hline Refuse collection & 0,2 & 0,0 & 0,2 \\
\hline Sewerage collection & 0,3 & 0,0 & 0,2 \\
\hline Other services relating to the dwelling & 1,4 & 0,2 & 1,2 \\
\hline Electricity & 1,7 & 2,3 & 1,8 \\
\hline Gas & 0,0 & 0,2 & 0,1 \\
\hline Liquid fuels & 0,2 & 0,8 & 0,3 \\
\hline Solid fuels & 0,1 & 1,2 & 0,3 \\
\hline Furnishings, household equipment and routine maintenance of the dwelling & 6,5 & 8,8 & 6,9 \\
\hline Furniture and furnishings & 1,1 & 1,9 & 1,3 \\
\hline Carpets and other floor covering & 0,2 & 0,1 & 0,2 \\
\hline Repair of furniture, furnishings and floor covering & 0,0 & 0,0 & 0,0 \\
\hline Household textiles & 1,1 & 2,3 & 1,3 \\
\hline Major household appliances & 0,7 & 1,2 & 0,8 \\
\hline Small electrical household appliances & 0,1 & 0,2 & 0,1 \\
\hline
\end{tabular}




\begin{tabular}{|c|c|c|c|}
\hline & Urban & Rural & Total \\
\hline Glassware, tableware and household utensils & 0,2 & 0,3 & 0,2 \\
\hline Small tools and miscellaneous accessories & 0,1 & 0,1 & 0,1 \\
\hline Non-durable household goods & 0,7 & 1,4 & 0,8 \\
\hline Domestic services and household arcticles & 2,2 & 1,2 & 2,1 \\
\hline Out-patient services & 0,8 & 1,1 & 0,9 \\
\hline Hospital services & 0,2 & 0,1 & 0,2 \\
\hline Transport & 20,8 & 15,3 & 19,9 \\
\hline Motor cars & 12,4 & 6,2 & 11,4 \\
\hline Motorcycles & 0,1 & 0,1 & 0,1 \\
\hline Bicycles & 0,0 & 0,1 & 0,0 \\
\hline Passenger transport by rail & 0,2 & 0,1 & 0,2 \\
\hline Passenger transport by road & 2,5 & 5,3 & 2,9 \\
\hline Passenger transport by air & 0,3 & 0,1 & 0,3 \\
\hline Passenger transport by sea and inland waterway & 0,0 & 0,0 & 0,0 \\
\hline Other puchased transport services & 0,0 & 0,1 & 0,0 \\
\hline Cost for other modes of transport & 0,0 & 0,0 & 0,0 \\
\hline
\end{tabular}




\begin{tabular}{|c|c|c|c|}
\hline & Urban & Rural & Total \\
\hline Communication & 3,6 & 3,2 & 3,5 \\
\hline Postal services & 0,1 & 0,1 & 0,1 \\
\hline Telephone and telefax equipment & 0,4 & 0,7 & 0,4 \\
\hline Telephone and telefax services & 3,2 & 2,4 & 3,0 \\
\hline Recreation and culture & 4,9 & 3,1 & 4,6 \\
\hline Audio-visual, photographic and information processing equipment & 1,5 & 1,4 & 1,5 \\
\hline Other major durables for recreation and culture & 0,1 & 0,1 & 0,1 \\
\hline Other recreational items and equipment, garden and pets & 0,9 & 0,4 & 0,8 \\
\hline Recreational and cultural services & 1,4 & 0,6 & 1,3 \\
\hline Newspapers, books and stationery & 0,8 & 0,6 & 0,8 \\
\hline Package holidays & 0,2 & 0,0 & 0,2 \\
\hline Education & 2,3 & 3,0 & 2,4 \\
\hline Pre-primary and primary education & 0,6 & 0,6 & 0,6 \\
\hline Secondary education & 0,6 & 0,8 & 0,6 \\
\hline Tertiary education & 1,0 & 0,8 & 0,9 \\
\hline Education not definable by level & 0,1 & 0,8 & 0,2 \\
\hline Restaurants and hotels & 2,3 & 1,9 & 2,2 \\
\hline Beverages in restaurants, cafes, canteens and the like & 0,3 & 0,5 & 0,4 \\
\hline Meals in restaurants, cafes, canteens and the like & 1,1 & 0,7 & 1,0 \\
\hline Accommodation services & 0,9 & 0,6 & 0,8 \\
\hline
\end{tabular}




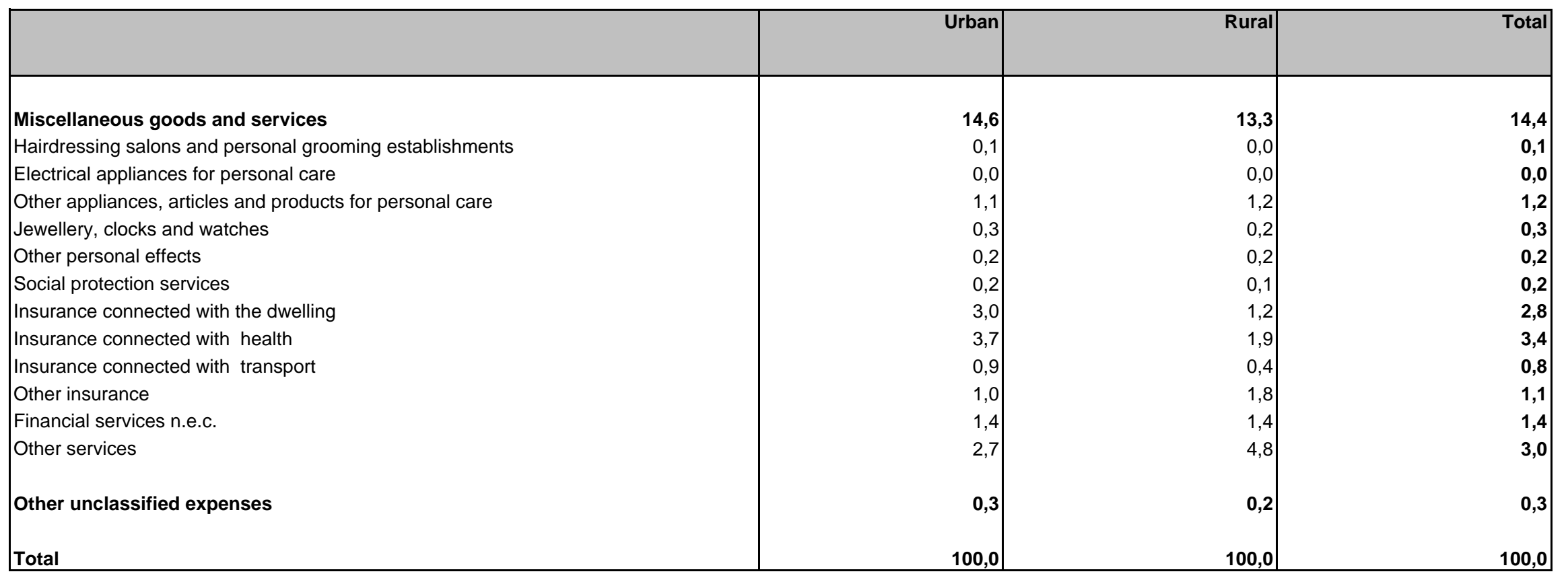

Due to rounding, figures do not necessarily add up to totals 


\section{Expenditure}

Table 2.10 - Percentage distribution of annual household consumption expenditure by main expenditure group and expenditure deciles

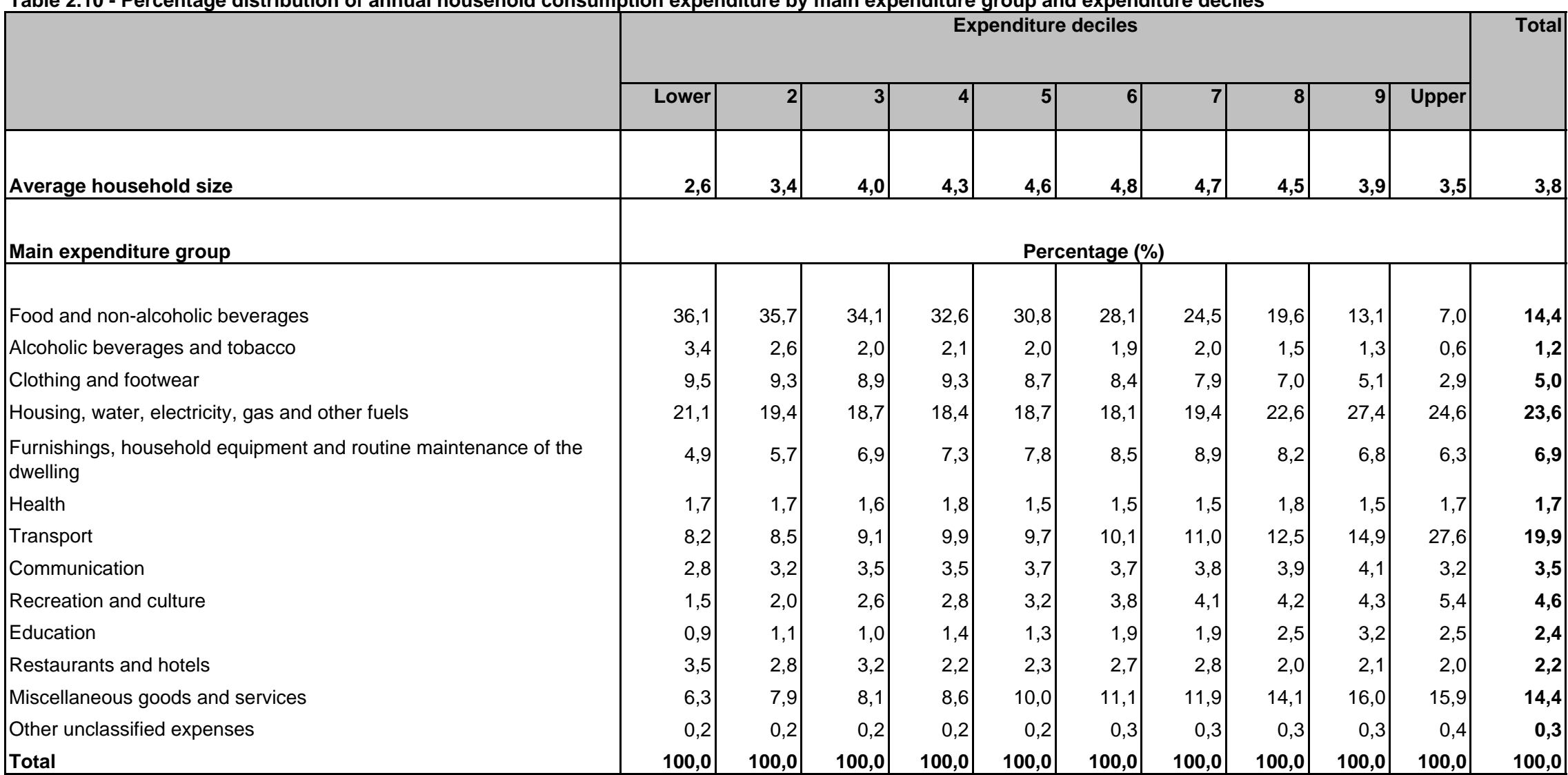

Due to rounding, figures do not necessarily add up to totals 


\section{Expenditure}

Table 2.11 - Percentage distribution of annual household consumption expenditure by secondary group and expenditure deciles

\begin{tabular}{|c|c|c|c|c|c|c|c|c|c|c|c|}
\hline & & & & $\overline{E x}$ & nditur & lecile & & & & & Total \\
\hline & Lower & 2 & 3 & 4 & 5 & 6 & 7 & 8 & 9 & Upper & \\
\hline Average household size & 2,6 & 3,4 & 4,0 & 4,3 & 4,6 & 4,8 & 4,7 & 4,5 & 3,9 & 3,5 & 3,8 \\
\hline Secondary expenditure group & & & & & Per & tage & & & & & \\
\hline Food and non-alcoholic beverages & 36,1 & 35,7 & 34,1 & 32,6 & 30,8 & 28,1 & 24,5 & 19,6 & 13,1 & 7,0 & 14,4 \\
\hline Food & 33,7 & 33,0 & 31,4 & 29,8 & 27,9 & 25,3 & 21,8 & 17,0 & 10,8 & 5,0 & 12,2 \\
\hline Non-alcoholic beverages & 1,9 & 2,0 & 1,9 & 1,8 & 2,0 & 1,9 & 1,7 & 1,5 & 1,1 & 0,6 & 1,1 \\
\hline Unspecified food & 0,6 & 0,7 & 0,8 & 1,0 & 0,9 & 1,0 & 1,0 & 1,2 & 1,2 & 1,4 & 1,2 \\
\hline Alcoholic beverages and tobacco & 3,4 & 2,6 & 2,0 & 2,1 & 2,0 & 1,9 & 2,0 & 1,5 & 1,3 & 0,6 & 1,2 \\
\hline Alcoholic beverages & 1,2 & 0,9 & 0,6 & 0,8 & 0,7 & 0,8 & 0,8 & 0,6 & 0,5 & 0,3 & 0,5 \\
\hline Tobacco & 2,2 & 1,7 & 1,5 & 1,2 & 1,3 & 1,1 & 1,2 & 0,9 & 0,7 & 0,3 & 0,7 \\
\hline Clothing and footwear & 9,5 & 9,3 & 8,9 & 9,3 & 8,7 & 8,4 & 7,9 & 7,0 & 5,1 & 2,9 & 5,0 \\
\hline Clothing & 6,4 & 6,4 & 6,0 & 6,5 & 6,0 & 5,8 & 5,6 & 5,0 & 3,7 & 2,1 & 3,5 \\
\hline Footwear & 3,0 & 2,9 & 2,9 & 2,8 & 2,7 & 2,6 & 2,3 & 2,0 & 1,4 & 0,8 & 1,5 \\
\hline Housing, water, electricity, gas and other fuels & 21,1 & 19,4 & 18,7 & 18,4 & 18,7 & 18,1 & 19,4 & 22,6 & 27,4 & 24,6 & 23,6 \\
\hline Actual rentals for housing & 4,4 & 3,6 & 3,7 & 3,6 & 4,0 & 3,7 & 4,7 & 5,7 & 6,1 & 2,1 & 3,6 \\
\hline Imputed rentals for housing & 7,7 & 7,1 & 6,9 & 6,6 & 6,7 & 6,9 & 7,2 & 9,1 & 13,8 & 15,4 & 12,6 \\
\hline Maintenance and repair of the dwelling & 0,3 & 0,2 & 0,4 & 0,6 & 0,5 & 0,6 & 0,8 & 0,9 & 1,0 & 2,7 & 1,7 \\
\hline Water supply and miscellaneous services relating to the dwelling & 1,5 & 1,7 & 1,7 & 2,2 & 2,5 & 2,3 & 2,9 & 3,9 & 4,1 & 3,2 & 3,2 \\
\hline Electricity, gas and other fuels & 7,2 & 6,7 & 6,0 & 5,5 & 5,1 & 4,6 & 3,9 & 3,0 & 2,5 & 1,2 & 2,4 \\
\hline
\end{tabular}




\begin{tabular}{|c|c|c|c|c|c|c|c|c|c|c|c|}
\hline & & & & & iditur & leciles & & & & & Total \\
\hline & Lower & 2 & 3 & 4 & 5 & 6 & 7 & 8 & 9 & Upper & \\
\hline $\begin{array}{l}\text { Furnishings, household equipment and routine maintenance of } \\
\text { the dwelling }\end{array}$ & 4,9 & 5,7 & 6,9 & 7,3 & 7,8 & 8,5 & 8,9 & 8,2 & 6,8 & 6,3 & 6,9 \\
\hline Furniture and furnishings, carpets and other floor covering & 0,3 & 0,4 & 1,0 & 1,0 & 1,5 & 1,9 & 2,4 & 2,2 & 1,5 & 1,3 & 1,5 \\
\hline Household textiles & 1,5 & 2,0 & 2,0 & 2,5 & 2,2 & 2,4 & 2,3 & 2,0 & 1,3 & 0,7 & 1,3 \\
\hline Household appliances & 0,4 & 0,6 & 1,2 & 1,3 & 1,7 & 2,2 & 1,9 & 1,5 & 1,0 & 0,6 & 1,0 \\
\hline Glassware, tableware and household utensils & 0,2 & 0,3 & 0,3 & 0,3 & 0,3 & 0,3 & 0,3 & 0,3 & 0,2 & 0,1 & 0,2 \\
\hline Tools and equipment for house and garden & 0,2 & 0,1 & 0,2 & 0,1 & 0,1 & 0,1 & 0,1 & 0,1 & 0,1 & 0,1 & 0,1 \\
\hline Goods and services for routine household maintenance & 2,3 & 2,3 & 2,2 & 2,1 & 2,0 & 1,7 & 1,9 & 2,1 & 2,7 & 3,5 & 2,9 \\
\hline Health & 1,7 & 1,7 & 1,6 & 1,8 & 1,5 & 1,5 & 1,5 & 1,8 & 1,5 & 1,7 & 1,7 \\
\hline Medical products, appliances and equipment & 0,7 & 0,6 & 0,6 & 0,6 & 0,6 & 0,6 & 0,6 & 0,7 & 0,6 & 0,6 & 0,6 \\
\hline Out-patient services & 0,9 & 1,0 & 1,0 & 1,1 & 0,9 & 0,9 & 0,9 & 1,0 & 0,7 & 0,9 & 0,9 \\
\hline Hospital services & 0,1 & 0,0 & 0,0 & 0,0 & 0,0 & 0,0 & 0,0 & 0,2 & 0,2 & 0,3 & 0,2 \\
\hline Transport & 8,2 & 8,5 & 9,1 & 9,9 & 9,7 & 10,1 & 11,0 & 12,5 & 14,9 & 27,6 & 19,9 \\
\hline Purchase of vehicles & 0,1 & 0,0 & 0,1 & 0,2 & 0,2 & 0,2 & 0,6 & 2,0 & 4,1 & 20,9 & 11,5 \\
\hline Operation of personal transport equipment & 0,1 & 0,4 & 0,4 & 0,7 & 0,9 & 1,3 & 2,6 & 5,1 & 8,0 & 5,7 & 5,0 \\
\hline Transport services & 8,0 & 8,1 & 8,6 & 9,0 & 8,6 & 8,6 & 7,8 & 5,5 & 2,8 & 0,9 & 3,4 \\
\hline Operational values of other modes of transport & 0,0 & 0,0 & 0,0 & 0,0 & 0,0 & 0,0 & 0,0 & 0,0 & 0,0 & 0,0 & 0,0 \\
\hline Communication & 2,8 & 3,2 & 3,5 & 3,5 & 3,7 & 3,7 & 3,8 & 3,9 & 4,1 & 3,2 & 3,5 \\
\hline Postal services & 0,0 & 0,0 & 0,0 & 0,0 & 0,0 & 0,0 & 0,0 & 0,1 & 0,1 & 0,1 & 0,1 \\
\hline Telephone and telefax equipment & 0,7 & 0,7 & 0,9 & 0,8 & 0,9 & 0,8 & 0,8 & 0,6 & 0,5 & 0,2 & 0,4 \\
\hline Telephone and telefax services & 2,2 & 2,5 & 2,6 & 2,7 & 2,8 & 2,9 & 3,0 & 3,2 & 3,5 & 3,0 & 3,0 \\
\hline Recreation and culture & 1,5 & 2,0 & 2,6 & 2,8 & 3,2 & 3,8 & 4,1 & 4,2 & 4,3 & 5,4 & 4,6 \\
\hline Audio-visual, photographic and information processing equipment & 0,4 & 0,7 & 1,1 & 1,3 & 1,6 & 2,0 & 1,9 & 1,8 & 1,5 & 1,4 & 1,5 \\
\hline Other major durables for recreation and culture & 0,0 & 0,0 & 0,0 & 0,0 & 0,0 & 0,1 & 0,0 & 0,1 & 0,1 & 0,1 & 0,1 \\
\hline Other recreational items and equipment, garden and pets & 0,1 & 0,2 & 0,2 & 0,2 & 0,2 & 0,2 & 0,3 & 0,4 & 0,7 & 1,2 & 0,8 \\
\hline Recreational and cultural services & 0,5 & 0,6 & 0,7 & 0,6 & 0,7 & 0,7 & 0,9 & 0,9 & 1,1 & 1,6 & 1,3 \\
\hline Newspapers, books and stationery & 0,5 & 0,5 & 0,6 & 0,6 & 0,6 & 0,7 & 0,9 & 1,0 & 0,8 & 0,7 & 0,8 \\
\hline Package holidays & 0,0 & 0,0 & 0,0 & 0,0 & 0,0 & 0,1 & 0,1 & 0,1 & 0,2 & 0,3 & 0,2 \\
\hline
\end{tabular}




\begin{tabular}{|c|c|c|c|c|c|c|c|c|c|c|c|}
\hline & \multicolumn{10}{|c|}{ Expenditure deciles } & \multirow[t]{2}{*}{ Total } \\
\hline & Lower & 2 & 3 & 4 & 5 & 6 & 7 & 8 & 9 & Upper & \\
\hline Education & 0,9 & 1,1 & 1,0 & 1,4 & 1,3 & 1,9 & 1,9 & 2,5 & 3,2 & 2,5 & 2,4 \\
\hline Pre-primary and primary education & 0,4 & 0,5 & 0,5 & 0,4 & 0,4 & 0,5 & 0,5 & 0,6 & 0,8 & 0,6 & 0,6 \\
\hline Secondary education & 0,5 & 0,5 & 0,4 & 0,4 & 0,4 & 0,5 & 0,5 & 0,6 & 0,6 & 0,7 & 0,6 \\
\hline Tertiary education & 0,0 & 0,1 & 0,1 & 0,5 & 0,4 & 0,9 & 0,9 & 1,2 & 1,7 & 0,8 & 0,9 \\
\hline Education not definable by level & 0,0 & 0,0 & 0,0 & 0,1 & 0,1 & 0,1 & 0,1 & 0,1 & 0,1 & 0,4 & 0,2 \\
\hline Restaurants and hotels & 3,5 & 2,8 & 3,2 & 2,2 & 2,3 & 2,7 & 2,8 & 2,0 & 2,1 & 2,0 & 2,2 \\
\hline Catering services & 3,3 & 2,6 & 3,0 & 2,0 & 2,1 & 2,3 & 2,4 & 1,5 & 1,2 & 1,0 & 1,4 \\
\hline Accommodation services & 0,2 & 0,2 & 0,2 & 0,2 & 0,2 & 0,3 & 0,4 & 0,6 & 0,9 & 1,1 & 0,8 \\
\hline Miscellaneous goods and services & 6,3 & 7,9 & 8,1 & 8,6 & 10,0 & 11,1 & 11,9 & 14,1 & 16,0 & 15,9 & 14,4 \\
\hline Personal care & 1,9 & 2,0 & 1,9 & 1,8 & 1,9 & 1,9 & 1,9 & 1,6 & 1,3 & 0,9 & 1,2 \\
\hline Personal effects & 0,4 & 0,4 & 0,4 & 0,4 & 0,4 & 0,4 & 0,5 & 0,4 & 0,4 & 0,5 & 0,5 \\
\hline Social protection & 0,1 & 0,1 & 0,2 & 0,2 & 0,2 & 0,2 & 0,2 & 0,3 & 0,2 & 0,2 & 0,2 \\
\hline Insurance & 2,2 & 2,2 & 2,1 & 2,2 & 2,3 & 2,7 & 3,2 & 6,0 & 9,0 & 10,7 & 8,1 \\
\hline Financial services n.e.c. & 0,4 & 0,8 & 0,9 & 0,9 & 1,1 & 1,1 & 1,3 & 1,4 & 1,7 & 1,5 & 1,4 \\
\hline Other services n.e.c. & 1,4 & 2,4 & 2,7 & 3,1 & 4,2 & 4,8 & 4,8 & 4,4 & 3,3 & 2,2 & 3,0 \\
\hline Other unclassified expenses & 0,2 & 0,2 & 0,2 & 0,2 & 0,2 & 0,3 & 0,3 & 0,3 & 0,3 & 0,4 & 0,3 \\
\hline Total & 100,0 & 100,0 & 100,0 & 100,0 & 100,0 & 100,0 & 100,0 & 100,0 & 100,0 & 100,0 & 100,0 \\
\hline
\end{tabular}

Due to rounding, figures do not necessarily add up to totals 


\section{Expenditure}

Table 2.12 - Percentage distribution of annual household consumption expenditure by third expenditure group and expenditure deciles

\begin{tabular}{|c|c|c|c|c|c|c|c|c|c|c|c|}
\hline & & & & & enditu & ciles & & & & & Total \\
\hline & Lower & 2 & 3 & 4 & 5 & 6 & 7 & 8 & 9 & Upper & \\
\hline Average household size & 2,6 & 3,4 & 4,0 & 4,3 & 4,6 & 4,8 & 4,7 & 4,5 & 3,9 & 3,5 & 3,8 \\
\hline Third expenditure group & & & & & Pel & tage ( & & & & & \\
\hline Food and non-alcoholic beverages & 36,1 & 35,7 & 34,1 & 32,6 & 30,8 & 28,1 & 24,5 & 19,6 & 13,1 & 7,0 & 14,4 \\
\hline Bread and cereals & 12,3 & 11,1 & 10,4 & 9,7 & 8,5 & 7,5 & 5,8 & 4,0 & 2,0 & 0,8 & 3,0 \\
\hline Meat & 7,0 & 7,7 & 7,4 & 7,6 & 7,5 & 7,2 & 6,7 & 5,7 & 3,7 & 1,6 & 3,6 \\
\hline Fish & 1,2 & 1,0 & 1,1 & 1,0 & 0,9 & 0,7 & 0,8 & 0,6 & 0,5 & 0,3 & 0,5 \\
\hline Milk, cheese and eggs & 2,7 & 2,9 & 2,7 & 2,8 & 2,7 & 2,5 & 2,3 & 2,0 & 1,5 & 0,7 & 1,4 \\
\hline Oils and fats & 1,6 & 1,5 & 1,5 & 1,3 & 1,2 & 1,1 & 0,8 & 0,7 & 0,4 & 0,2 & 0,5 \\
\hline Fruits & 0,6 & 0,6 & 0,6 & 0,6 & 0,6 & 0,5 & 0,5 & 0,4 & 0,4 & 0,3 & 0,4 \\
\hline Vegetables & 4,8 & 4,3 & 4,0 & 3,6 & 3,2 & 2,8 & 2,3 & 1,7 & 1,2 & 0,6 & 1,4 \\
\hline Sugar, jam, honey, chocolate and confectionery & 2,3 & 2,2 & 2,2 & 1,9 & 1,7 & 1,5 & 1,2 & 0,9 & 0,6 & 0,3 & 0,7 \\
\hline Food products n.e.c. & 1,2 & 1,7 & 1,6 & 1,5 & 1,7 & 1,5 & 1,3 & 1,0 & 0,6 & 0,3 & 0,7 \\
\hline Coffee, tea and cocoa & 0,8 & 0,7 & 0,7 & 0,6 & 0,6 & 0,5 & 0,4 & 0,3 & 0,2 & 0,1 & 0,3 \\
\hline Mineral waters, soft drinks, fruit and vegetable juices & 1,1 & 1,2 & 1,2 & 1,2 & 1,4 & 1,4 & 1,3 & 1,1 & 0,9 & 0,5 & 0,8 \\
\hline Unspecified food & 0,6 & 0,7 & 0,8 & 1,0 & 0,9 & 1,0 & 1,0 & 1,2 & 1,2 & 1,4 & 1,2 \\
\hline Alcoholic beverages and tobacco & 3,4 & 2,6 & 2,0 & 2,1 & 2,0 & 1,9 & 2,0 & 1,5 & 1,3 & 0,6 & 1,2 \\
\hline Spirits & 0,1 & 0,1 & 0,1 & 0,1 & 0,1 & 0,1 & 0,2 & 0,2 & 0,2 & 0,1 & 0,1 \\
\hline Wine & 0,1 & 0,1 & 0,1 & 0,2 & 0,0 & 0,1 & 0,1 & 0,1 & 0,1 & 0,1 & 0,1 \\
\hline Beer & 1,0 & 0,8 & 0,4 & 0,6 & 0,6 & 0,6 & 0,5 & 0,3 & 0,3 & 0,1 & 0,3 \\
\hline Tobacco & 2,2 & 1,7 & 1,5 & 1,2 & 1,3 & 1,1 & 1,2 & 0,9 & 0,7 & 0,3 & 0,7 \\
\hline
\end{tabular}




\begin{tabular}{|c|c|c|c|c|c|c|c|c|c|c|c|}
\hline & \multicolumn{10}{|c|}{ Expenditure deciles } & \multirow[t]{2}{*}{ Total } \\
\hline & Lower & 2 & 3 & 4 & 5 & 6 & 7 & 8 & 9 & Upper & \\
\hline Clothing and footwear & 9,5 & 9,3 & 8,9 & 9,3 & 8,7 & 8,4 & 7,9 & 7,0 & 5,1 & 2,9 & 5,0 \\
\hline Clothing materials & 0,0 & 0,1 & 0,0 & 0,1 & 0,1 & 0,1 & 0,1 & 0,1 & 0,0 & 0,0 & 0,0 \\
\hline Garments & 6,3 & 6,2 & 5,8 & 6,3 & 5,8 & 5,6 & 5,4 & 4,8 & 3,5 & 2,0 & 3,4 \\
\hline Other articles of clothing and clothing accessories & 0,1 & 0,1 & 0,1 & 0,1 & 0,1 & 0,1 & 0,1 & 0,1 & 0,1 & 0,1 & 0,1 \\
\hline Cleaning, repair and hire of clothing & 0,0 & 0,0 & 0,0 & 0,0 & 0,0 & 0,0 & 0,0 & 0,0 & 0,0 & 0,0 & 0,0 \\
\hline Shoes and other footwear & 3,0 & 2,8 & 2,9 & 2,8 & 2,7 & 2,6 & 2,3 & 2,0 & 1,4 & 0,8 & 1,4 \\
\hline Repair and hire of footwear & 0,0 & 0,0 & 0,0 & 0,0 & 0,0 & 0,0 & 0,0 & 0,0 & 0,0 & 0,0 & 0,0 \\
\hline Housing, water, electricity, gas and other fuels & 21,1 & 19,4 & 18,7 & 18,4 & 18,7 & 18,1 & 19,4 & 22,6 & 27,4 & 24,6 & 23,6 \\
\hline Actual rentals paid by tenants & 4,4 & 3,6 & 3,7 & 3,6 & 4,0 & 3,7 & 4,7 & 5,7 & 6,1 & 2,1 & 3,6 \\
\hline Imputed rentals of owner-occupiers & 7,7 & 7,1 & 6,9 & 6,6 & 6,7 & 6,9 & 7,2 & 9,1 & 13,8 & 15,4 & 12,6 \\
\hline Materials for maintenance and repair of the dwelling & 0,2 & 0,2 & 0,2 & 0,2 & 0,2 & 0,2 & 0,3 & 0,4 & 0,4 & 1,0 & 0,7 \\
\hline Service of the maintenance and repair of the dwelling & 0,1 & 0,1 & 0,2 & 0,4 & 0,3 & 0,3 & 0,5 & 0,6 & 0,6 & 1,7 & 1,1 \\
\hline Water and electricity & 0,2 & 0,2 & 0,3 & 0,4 & 0,4 & 0,4 & 0,7 & 1,4 & 1,3 & 1,0 & 0,9 \\
\hline Water supply & 0,4 & 0,5 & 0,5 & 0,7 & 0,8 & 0,8 & 0,8 & 0,8 & 0,8 & 0,5 & 0,6 \\
\hline Refuse collection & 0,3 & 0,3 & 0,3 & 0,3 & 0,3 & 0,3 & 0,3 & 0,3 & 0,3 & 0,1 & 0,2 \\
\hline Sewerage collection & 0,2 & 0,3 & 0,2 & 0,3 & 0,3 & 0,2 & 0,3 & 0,3 & 0,3 & 0,2 & 0,2 \\
\hline Other services relating to the dwelling & 0,4 & 0,4 & 0,3 & 0,5 & 0,6 & 0,6 & 0,8 & 1,1 & 1,5 & 1,4 & 1,2 \\
\hline Electricity & 2,8 & 2,7 & 2,9 & 2,8 & 2,8 & 2,9 & 2,7 & 2,5 & 2,2 & 1,1 & 1,8 \\
\hline Gas & 0,0 & 0,1 & 0,1 & 0,1 & 0,1 & 0,1 & 0,1 & 0,1 & 0,1 & 0,0 & 0,1 \\
\hline Liquid fuels & 2,6 & 2,1 & 1,6 & 1,5 & 1,1 & 0,8 & 0,5 & 0,2 & 0,1 & 0,0 & 0,3 \\
\hline Solid fuels & 1,8 & 1,7 & 1,5 & 1,1 & 1,1 & 0,8 & 0,5 & 0,2 & 0,1 & 0,0 & 0,3 \\
\hline $\begin{array}{l}\text { Furnishings, household equipment and routine } \\
\text { maintenance of the dwelling }\end{array}$ & 4,9 & 5,7 & 6,9 & 7,3 & 7,8 & 8,5 & 8,9 & 8,2 & 6,8 & 6,3 & 6,9 \\
\hline Furniture and furnishings & 0,2 & 0,3 & 1,0 & 0,9 & 1,4 & 1,7 & 2,2 & 2,0 & 1,3 & 1,0 & 1,3 \\
\hline Carpets and other floor covering & 0,0 & 0,1 & 0,1 & 0,1 & 0,1 & 0,1 & 0,1 & 0,2 & 0,2 & 0,2 & 0,2 \\
\hline Repair of furniture, furnishings and floor covering & 0,0 & 0,0 & 0,0 & 0,0 & 0,0 & 0,0 & 0,0 & 0,0 & 0,0 & 0,1 & 0,0 \\
\hline Household textiles & 1,5 & 2,0 & 2,0 & 2,5 & 2,2 & 2,4 & 2,3 & 2,0 & 1,3 & 0,7 & 1,3 \\
\hline Major household appliances & 0,2 & 0,4 & 0,9 & 1,1 & 1,5 & 1,9 & 1,7 & 1,3 & 0,8 & 0,5 & 0,8 \\
\hline Small electrical household appliances & 0,2 & 0,2 & 0,2 & 0,2 & 0,2 & 0,2 & 0,2 & 0,2 & 0,1 & 0,1 & 0,1 \\
\hline
\end{tabular}




\begin{tabular}{|c|c|c|c|c|c|c|c|c|c|c|c|}
\hline & \multicolumn{10}{|c|}{ Expenditure deciles } & \multirow[t]{2}{*}{ Total } \\
\hline & Lower & 2 & 3 & 4 & 5 & 6 & 7 & 8 & 9 & Upper & \\
\hline Repair of household appliances & 0,0 & 0,0 & 0,0 & 0,0 & 0,0 & 0,0 & 0,1 & 0,0 & 0,0 & 0,0 & 0,0 \\
\hline Glassware, tableware and household utensils & 0,2 & 0,3 & 0,3 & 0,3 & 0,3 & 0,3 & 0,3 & 0,3 & 0,2 & 0,1 & 0,2 \\
\hline Major tools and equipment & 0,0 & 0,0 & 0,0 & 0,0 & 0,0 & 0,0 & 0,0 & 0,0 & 0,0 & 0,1 & 0,0 \\
\hline Small tools and miscellaneous accessories & 0,2 & 0,1 & 0,2 & 0,1 & 0,1 & 0,1 & 0,1 & 0,1 & 0,1 & 0,1 & 0,1 \\
\hline Non-durable household goods & 2,2 & 2,2 & 2,1 & 1,8 & 1,8 & 1,6 & 1,3 & 1,1 & 0,7 & 0,4 & 0,8 \\
\hline Domestic services and household arcticles & 0,1 & 0,1 & 0,2 & 0,3 & 0,2 & 0,2 & 0,6 & 1,0 & 1,9 & 3,1 & 2,1 \\
\hline Health & 1,7 & 1,7 & 1,6 & 1,8 & 1,5 & 1,5 & 1,5 & 1,8 & 1,5 & 1,7 & 1,7 \\
\hline Medical products, appliances and equipment & 0,7 & 0,6 & 0,6 & 0,6 & 0,6 & 0,6 & 0,6 & 0,7 & 0,6 & 0,6 & 0,6 \\
\hline Out-patient services & 0,9 & 1,0 & 1,0 & 1,1 & 0,9 & 0,9 & 0,9 & 1,0 & 0,7 & 0,9 & 0,9 \\
\hline Hospital services & 0,1 & 0,0 & 0,0 & 0,0 & 0,0 & 0,0 & 0,0 & 0,2 & 0,2 & 0,3 & 0,2 \\
\hline Transport & 8,2 & 8,5 & 9,1 & 9,9 & 9,7 & 10,1 & 11,0 & 12,5 & 14,9 & 27,6 & 19,9 \\
\hline Motor cars & 0,0 & 0,0 & 0,1 & 0,2 & 0,1 & 0,2 & 0,6 & 2,0 & 4,1 & 20,7 & 11,4 \\
\hline Motorcycles & & 0,0 & - & - & - & 0,0 & 0,0 & 0,0 & 0,0 & 0,1 & 0,1 \\
\hline Bicycles & 0,0 & 0,0 & 0,0 & 0,0 & 0,0 & 0,0 & 0,0 & 0,0 & 0,0 & 0,0 & 0,0 \\
\hline Animal-drawn vehicles & 0,0 & 0,0 & 0,0 & 0,0 & 0,0 & 0,0 & 0,0 & 0,0 & 0,0 & 0,0 & 0,0 \\
\hline Spare parts and accessories & 0,0 & 0,0 & 0,0 & 0,1 & 0,1 & 0,2 & 0,4 & 0,7 & 1,0 & 0,7 & 0,6 \\
\hline Fuels and lubricants & 0,0 & 0,1 & 0,1 & 0,4 & 0,4 & 0,8 & 1,7 & 3,5 & 5,6 & 3,9 & 3,5 \\
\hline Maintenance and repair of personal transport equipment & & 0,0 & 0,0 & 0,0 & 0,1 & 0,0 & 0,2 & 0,4 & 0,7 & 0,6 & 0,5 \\
\hline $\begin{array}{l}\text { Other services in respect of personal transport } \\
\text { equipment }\end{array}$ & 0,1 & 0,3 & 0,3 & 0,2 & 0,3 & 0,3 & 0,4 & 0,5 & 0,7 & 0,5 & 0,5 \\
\hline Passenger transport by rail & 0,5 & 0,5 & 0,6 & 0,6 & 0,6 & 0,4 & 0,4 & 0,2 & 0,1 & 0,0 & 0,2 \\
\hline Passenger transport by road & 7,5 & 7,5 & 7,9 & 8,4 & 8,0 & 8,1 & 7,4 & 5,2 & 2,5 & 0,4 & 2,9 \\
\hline Passenger transport by air & 0,0 & 0,0 & 0,0 & 0,0 & 0,0 & 0,0 & 0,0 & 0,0 & 0,2 & 0,5 & 0,3 \\
\hline
\end{tabular}




\begin{tabular}{|c|c|c|c|c|c|c|c|c|c|c|c|}
\hline & \multicolumn{10}{|c|}{ Expenditure deciles } & \multirow[t]{2}{*}{ Total } \\
\hline & Lower & 2 & 3 & 4 & 5 & 6 & 7 & 8 & 9 & Upper & \\
\hline Passenger transport by sea and inland waterway & & 0,0 & 0,0 & - & 0,0 & - & 0,0 & 0,0 & 0,0 & 0,0 & 0,0 \\
\hline Other puchased transport services & 0,1 & 0,0 & 0,1 & 0,0 & 0,1 & 0,0 & 0,1 & 0,0 & 0,0 & 0,0 & 0,0 \\
\hline Cost for other modes of transport & 0,0 & 0,0 & 0,0 & 0,0 & 0,0 & 0,0 & 0,0 & 0,0 & 0,0 & 0,0 & 0,0 \\
\hline Communication & 2,8 & 3,2 & 3,5 & 3,5 & 3,7 & 3,7 & 3,8 & 3,9 & 4,1 & 3,2 & 3,5 \\
\hline Postal services & 0,0 & 0,0 & 0,0 & 0,0 & 0,0 & 0,0 & 0,0 & 0,1 & 0,1 & 0,1 & 0,1 \\
\hline Telephone and telefax equipment & 0,7 & 0,7 & 0,9 & 0,8 & 0,9 & 0,8 & 0,8 & 0,6 & 0,5 & 0,2 & 0,4 \\
\hline Telephone and telefax services & 2,2 & 2,5 & 2,6 & 2,7 & 2,8 & 2,9 & 3,0 & 3,2 & 3,5 & 3,0 & 3,0 \\
\hline Recreation and culture & 1,5 & 2,0 & 2,6 & 2,8 & 3,2 & 3,8 & 4,1 & 4,2 & 4,3 & 5,4 & 4,6 \\
\hline $\begin{array}{l}\text { Audio-visual, photographic and information processing } \\
\text { equipment }\end{array}$ & 0,4 & 0,7 & 1,1 & 1,3 & 1,6 & 2,0 & 1,9 & 1,8 & 1,5 & 1,4 & 1,5 \\
\hline Other major durables for recreation and culture & 0,0 & 0,0 & 0,0 & 0,0 & 0,0 & 0,1 & 0,0 & 0,1 & 0,1 & 0,1 & 0,1 \\
\hline $\begin{array}{l}\text { Other recreational items and equipment, garden and } \\
\text { pets }\end{array}$ & 0,1 & 0,2 & 0,2 & 0,2 & 0,2 & 0,2 & 0,3 & 0,4 & 0,7 & 1,2 & 0,8 \\
\hline Recreational and cultural services & 0,5 & 0,6 & 0,7 & 0,6 & 0,7 & 0,7 & 0,9 & 0,9 & 1,1 & 1,6 & 1,3 \\
\hline Newspapers, books and stationery & 0,5 & 0,5 & 0,6 & 0,6 & 0,6 & 0,7 & 0,9 & 1,0 & 0,8 & 0,7 & 0,8 \\
\hline Package holidays & 0,0 & 0,0 & 0,0 & 0,0 & 0,0 & 0,1 & 0,1 & 0,1 & 0,2 & 0,3 & 0,2 \\
\hline Education & 0,9 & 1,1 & 1,0 & 1,4 & 1,3 & 1,9 & 1,9 & 2,5 & 3,2 & 2,5 & 2,4 \\
\hline Pre-primary and primary education & 0,4 & 0,5 & 0,5 & 0,4 & 0,4 & 0,5 & 0,5 & 0,6 & 0,8 & 0,6 & 0,6 \\
\hline Secondary education & 0,5 & 0,5 & 0,4 & 0,4 & 0,4 & 0,5 & 0,5 & 0,6 & 0,6 & 0,7 & 0,6 \\
\hline Tertiary education & 0,0 & 0,1 & 0,1 & 0,5 & 0,4 & 0,9 & 0,9 & 1,2 & 1,7 & 0,8 & 0,9 \\
\hline Education not definable by level & 0,0 & 0,0 & 0,0 & 0,1 & 0,1 & 0,1 & 0,1 & 0,1 & 0,1 & 0,4 & 0,2 \\
\hline Restaurants and hotels & 3,5 & 2,8 & 3,2 & 2,2 & 2,3 & 2,7 & 2,8 & 2,0 & 2,1 & 2,0 & 2,2 \\
\hline Beverages in restaurants, cafes, canteens and the like & 1,4 & 1,1 & 1,3 & 0,8 & 1,0 & 0,9 & 0,7 & 0,6 & 0,2 & 0,1 & 0,4 \\
\hline Meals in restaurants, cafes, canteens and the like & 1,9 & 1,5 & 1,6 & 1,1 & 1,1 & 1,5 & 1,8 & 0,9 & 1,0 & 0,8 & 1,0 \\
\hline Accommodation services & 0,2 & 0,2 & 0,2 & 0,2 & 0,2 & 0,3 & 0,4 & 0,6 & 0,9 & 1,1 & 0,8 \\
\hline
\end{tabular}




\begin{tabular}{|c|c|c|c|c|c|c|c|c|c|c|c|}
\hline & \multicolumn{10}{|c|}{ Expenditure deciles } & \multirow[t]{2}{*}{ Total } \\
\hline & Lower & 2 & 3 & 4 & 5 & 6 & 7 & 8 & \begin{tabular}{l|l}
9 & \\
\end{tabular} & Upper & \\
\hline Miscellaneous goods and services & 6,3 & 7,9 & 8,1 & 8,6 & 10,0 & 11,1 & 11,9 & 14,1 & 16,0 & 15,9 & 14,4 \\
\hline $\begin{array}{l}\text { Hairdressing salons and personal grooming } \\
\text { establishments }\end{array}$ & 0,0 & 0,0 & 0,0 & 0,0 & 0,0 & 0,0 & 0,1 & 0,1 & 0,1 & 0,1 & 0,1 \\
\hline Electrical appliances for personal care & & 0,0 & 0,0 & 0,0 & 0,0 & 0,0 & 0,0 & 0,0 & 0,0 & 0,0 & 0,0 \\
\hline Other appliances, articles and products for personal care & 1,9 & 1,9 & 1,8 & 1,7 & 1,9 & 1,8 & 1,9 & 1,5 & 1,2 & 0,7 & 1,2 \\
\hline Jewellery, clocks and watches & 0,1 & 0,1 & 0,1 & 0,1 & 0,2 & 0,2 & 0,2 & 0,2 & 0,2 & 0,3 & 0,3 \\
\hline Other personal effects & 0,2 & 0,3 & 0,3 & 0,3 & 0,3 & 0,3 & 0,3 & 0,2 & 0,2 & 0,2 & 0,2 \\
\hline Social protection services & 0,1 & 0,1 & 0,2 & 0,2 & 0,2 & 0,2 & 0,2 & 0,3 & 0,2 & 0,2 & 0,2 \\
\hline Insurance connected with the dwelling & & 0,0 & 0,0 & 0,0 & 0,0 & 0,1 & 0,1 & 0,8 & 2,2 & 4,6 & 2,8 \\
\hline Insurance connected with health & 0,0 & 0,0 & 0,1 & 0,1 & 0,2 & 0,5 & 1,0 & 3,1 & 4,7 & 4,4 & 3,4 \\
\hline Insurance connected with transport & 0,0 & 0,0 & 0,0 & 0,0 & 0,0 & 0,0 & 0,1 & 0,2 & 0,9 & 1,3 & 0,8 \\
\hline Other insurance & 2,2 & 2,2 & 2,0 & 2,1 & 2,1 & 2,1 & 2,0 & 1,9 & 1,3 & 0,4 & 1,1 \\
\hline Financial services n.e.c. & 0,4 & 0,8 & 0,9 & 0,9 & 1,1 & 1,1 & 1,3 & 1,4 & 1,7 & 1,5 & 1,4 \\
\hline Other services & 1,4 & 2,4 & 2,7 & 3,1 & 4,2 & 4,8 & 4,8 & 4,4 & 3,3 & 2,2 & 3,0 \\
\hline Other unclassified expenses & 0,2 & 0,2 & 0,2 & 0,2 & 0,2 & 0,3 & 0,3 & 0,3 & 0,3 & 0,4 & 0,3 \\
\hline Total & 100,0 & 100,0 & 100,0 & 100,0 & 100,0 & 100,0 & 100,0 & 100,0 & 100,0 & 100,0 & 100,0 \\
\hline
\end{tabular}

Due to rounding, figures do not necessarily add up to totals

- No expenditure 


\section{Expenditure}

Table 2.13 - Percentage distribution of annual household consumption expenditure by main expenditure group and income deciles

\begin{tabular}{|c|c|c|c|c|c|c|c|c|c|c|c|}
\hline & \multicolumn{10}{|c|}{ Income deciles } & \multirow[t]{2}{*}{ Total } \\
\hline & Lower & 2 & 3 & 4 & 5 & 6 & 7 & 8 & 9 & Upper & \\
\hline Average household size & 2,8 & 3,3 & 3,8 & 4,4 & 4,7 & 4,9 & 4,6 & 4,4 & 3,8 & 3,6 & 3,8 \\
\hline Main expenditure group & \multicolumn{11}{|c|}{ Percentage (\%) } \\
\hline Food and non-alcoholic beverages & 32,8 & 33,2 & 30,9 & 29,7 & 28,9 & 26,1 & 22,2 & 16,8 & 11,1 & 7,3 & 14,4 \\
\hline Alcoholic beverages and tobacco & 2,1 & 2,2 & 1,7 & 1,8 & 1,8 & 2,1 & 1,9 & 1,4 & 1,0 & 0,7 & 1,2 \\
\hline Clothing and footwear & 8,2 & 8,0 & 8,3 & 8,2 & 8,2 & 7,6 & 7,6 & 6,2 & 4,4 & 3,1 & 5,0 \\
\hline Housing, water, electricity, gas and other fuels & 18,9 & 17,6 & 19,0 & 18,3 & 18,3 & 18,3 & 19,9 & 22,4 & 24,7 & 26,3 & 23,6 \\
\hline $\begin{array}{l}\text { Furnishings, household equipment and routine maintenance of the } \\
\text { dwelling }\end{array}$ & 6,2 & 7,2 & 8,2 & 8,3 & 7,8 & 8,4 & 7,8 & 7,3 & 5,9 & 6,6 & 6,9 \\
\hline Health & 1,3 & 1,7 & 1,6 & 1,6 & 1,8 & 1,7 & 1,4 & 1,6 & 1,6 & 1,8 & 1,7 \\
\hline Transport & 10,5 & 12,3 & 10,9 & 10,9 & 11,4 & 13,2 & 14,3 & 16,4 & 22,9 & 24,0 & 19,9 \\
\hline Communication & 3,0 & 2,9 & 3,3 & 3,2 & 3,5 & 3,4 & 3,9 & 3,7 & 3,6 & 3,5 & 3,5 \\
\hline Recreation and culture & 2,2 & 2,2 & 3,1 & 3,1 & 3,6 & 3,9 & 4,2 & 3,8 & 4,3 & 5,6 & 4,6 \\
\hline Education & 2,2 & 1,9 & 1,8 & 2,0 & 2,0 & 1,7 & 2,4 & 3,9 & 2,7 & 2,2 & 2,4 \\
\hline Restaurants and hotels & 4,2 & 2,3 & 2,2 & 2,1 & 2,3 & 2,7 & 2,6 & 2,0 & 2,1 & 2,1 & 2,2 \\
\hline Miscellaneous goods and services & 8,2 & 8,3 & 8,7 & 10,7 & 10,3 & 10,7 & 11,5 & 14,3 & 15,4 & 16,5 & 14,4 \\
\hline Other unclassified expenses & 0,2 & 0,2 & 0,2 & 0,2 & 0,3 & 0,3 & 0,3 & 0,3 & 0,3 & 0,3 & 0,3 \\
\hline Total & 100,0 & 100,0 & 100,0 & 100,0 & 100,0 & 100,0 & 100,0 & 100,0 & 100,0 & 100,0 & 100,0 \\
\hline
\end{tabular}

Due to rounding, figures do not necessarily add up to totals 


\section{Expenditure}

Table 2.14 - Percentage distribution of annual household consumption expenditure by secondary expenditure group and income deciles

\begin{tabular}{|c|c|c|c|c|c|c|c|c|c|c|c|}
\hline & & & & & come & iles & & & & & Total \\
\hline & Lower & 2 & 3 & 4 & 5 & 6 & 7 & 8 & 9 & Upper & \\
\hline Average household size & 2,8 & 3,3 & 3,8 & 4,4 & 4,7 & 4,9 & 4,6 & 4,4 & 3,8 & 3,6 & 3,8 \\
\hline Secondary expenditure group & & & & & $\mathrm{Pe}$ & tage & & & & & \\
\hline Food and non-alcoholic beverages & 32,8 & 33,2 & 30,9 & 29,7 & 28,9 & 26,1 & 22,2 & 16,8 & 11,1 & 7,3 & 14,4 \\
\hline Food & 30,2 & 30,6 & 28,2 & 27,0 & 26,1 & 23,0 & 19,3 & 14,2 & 9,0 & 5,3 & 12,2 \\
\hline Non-alcoholic beverages & 1,8 & 1,8 & 1,8 & 1,8 & 1,8 & 1,8 & 1,6 & 1,3 & 0,9 & 0,7 & 1,1 \\
\hline Unspecified food & 0,8 & 0,8 & 0,9 & 0,9 & 1,0 & 1,2 & 1,2 & 1,3 & 1,2 & 1,4 & 1,2 \\
\hline Alcoholic beverages and tobacco & 2,1 & 2,2 & 1,7 & 1,8 & 1,8 & 2,1 & 1,9 & 1,4 & 1,0 & 0,7 & 1,2 \\
\hline Alcoholic beverages & 0,9 & 0,7 & 0,6 & 0,8 & 0,8 & 1,0 & 0,7 & 0,5 & 0,4 & 0,3 & 0,5 \\
\hline Tobacco & 1,2 & 1,4 & 1,2 & 1,0 & 1,1 & 1,1 & 1,2 & 0,9 & 0,6 & 0,4 & 0,7 \\
\hline Clothing and footwear & 8,2 & 8,0 & 8,3 & 8,2 & 8,2 & 7,6 & 7,6 & 6,2 & 4,4 & 3,1 & 5,0 \\
\hline Clothing & 5,5 & 5,5 & 5,8 & 5,7 & 5,7 & 5,3 & 5,4 & 4,4 & 3,2 & 2,2 & 3,5 \\
\hline Footwear & 2,6 & 2,5 & 2,6 & 2,5 & 2,6 & 2,4 & 2,2 & 1,8 & 1,2 & 0,9 & 1,5 \\
\hline Housing, water, electricity, gas and other fuels & 18,9 & 17,6 & 19,0 & 18,3 & 18,3 & 18,3 & 19,9 & 22,4 & 24,7 & 26,3 & 23,6 \\
\hline Actual rentals for housing & 6,1 & 3,6 & 3,7 & 3,1 & 4,3 & 4,0 & 5,6 & 5,2 & 6,0 & 1,7 & 3,6 \\
\hline Imputed rentals for housing & 4,8 & 5,6 & 6,8 & 7,0 & 6,4 & 6,9 & 7,5 & 9,7 & 11,9 & 17,1 & 12,6 \\
\hline Maintenance and repair of the dwelling & 0,4 & 0,7 & 0,7 & 0,9 & 0,6 & 0,8 & 0,9 & 0,9 & 1,2 & 2,8 & 1,7 \\
\hline Water supply and miscellaneous services relating to the dwelling & 2,4 & 1,9 & 2,3 & 2,4 & 2,4 & 2,9 & 2,7 & 3,8 & 3,4 & 3,4 & 3,2 \\
\hline Electricity, gas and other fuels & 5,3 & 5,8 & 5,5 & 4,9 & 4,7 & 3,8 & 3,3 & 2,8 & 2,1 & 1,3 & 2,4 \\
\hline
\end{tabular}




\begin{tabular}{|c|c|c|c|c|c|c|c|c|c|c|c|}
\hline & \multicolumn{10}{|c|}{ Income deciles } & \multirow[t]{2}{*}{ Total } \\
\hline & Lower & 2 & 3 & 4 & 5 & 6 & 7 & 8 & 9 & Upper & \\
\hline $\begin{array}{l}\text { Furnishings, household equipment and routine maintenance of the } \\
\text { dwelling }\end{array}$ & 6,2 & 7,2 & 8,2 & 8,3 & 7,8 & 8,4 & 7,8 & 7,3 & 5,9 & 6,6 & 6,9 \\
\hline Furniture and furnishings, carpets and other floor covering & 0,8 & 1,2 & 1,7 & 2,0 & 1,6 & 2,0 & 2,1 & 1,8 & 1,3 & 1,2 & 1,5 \\
\hline Household textiles & 1,7 & 2,1 & 2,4 & 2,3 & 2,2 & 2,2 & 2,0 & 1,8 & 1,1 & 0,7 & 1,3 \\
\hline Household appliances & 1,1 & 1,3 & 1,5 & 1,6 & 1,5 & 1,9 & 1,5 & 1,4 & 0,8 & 0,6 & 1,0 \\
\hline Glassware, tableware and household utensils & 0,3 & 0,3 & 0,3 & 0,3 & 0,3 & 0,3 & 0,3 & 0,2 & 0,2 & 0,1 & 0,2 \\
\hline Tools and equipment for house and garden & 0,2 & 0,1 & 0,1 & 0,1 & 0,1 & 0,1 & 0,1 & 0,1 & 0,1 & 0,1 & 0,1 \\
\hline Goods and services for routine household maintenance & 2,2 & 2,2 & 2,1 & 2,0 & 2,1 & 1,9 & 1,9 & 2,0 & 2,4 & 3,8 & 2,9 \\
\hline Health & 1,3 & 1,7 & 1,6 & 1,6 & 1,8 & 1,7 & 1,4 & 1,6 & 1,6 & 1,8 & 1,7 \\
\hline Medical products, appliances and equipment & 0,5 & 0,6 & 0,6 & 0,6 & 0,6 & 0,5 & 0,5 & 0,6 & 0,6 & 0,7 & 0,6 \\
\hline Out-patient services & 0,7 & 1,0 & 1,0 & 1,0 & 1,0 & 1,1 & 0,8 & 0,8 & 0,7 & 0,9 & 0,9 \\
\hline Hospital services & 0,1 & 0,0 & 0,0 & 0,0 & 0,2 & 0,1 & 0,1 & 0,2 & 0,3 & 0,2 & 0,2 \\
\hline Transport & 10,5 & 12,3 & 10,9 & 10,9 & 11,4 & 13,2 & 14,3 & 16,4 & 22,9 & 24,0 & 19,9 \\
\hline Purchase of vehicles & 2,5 & 4,2 & 3,1 & 2,2 & 2,1 & 3,4 & 3,0 & 6,3 & 13,3 & 17,0 & 11,5 \\
\hline Operation of personal transport equipment & 1,2 & 0,8 & 0,8 & 1,2 & 1,5 & 2,7 & 3,6 & 4,9 & 7,2 & 5,9 & 5,0 \\
\hline Transport services & 6,8 & 7,3 & 7,0 & 7,5 & 7,8 & 7,1 & 7,7 & 5,2 & 2,4 & 1,1 & 3,4 \\
\hline Operational values of other modes of transport & 0,0 & 0,0 & 0,0 & 0,0 & 0,0 & 0,0 & 0,0 & 0,0 & 0,0 & 0,0 & 0,0 \\
\hline Communication & 3,0 & 2,9 & 3,3 & 3,2 & 3,5 & 3,4 & 3,9 & 3,7 & 3,6 & 3,5 & 3,5 \\
\hline Postal services & 0,0 & 0,0 & 0,0 & 0,0 & 0,0 & 0,0 & 0,1 & 0,1 & 0,1 & 0,1 & 0,1 \\
\hline Telephone and telefax equipment & 0,7 & 0,7 & 0,7 & 0,7 & 0,8 & 0,7 & 0,7 & 0,6 & 0,4 & 0,2 & 0,4 \\
\hline Telephone and telefax services & 2,2 & 2,2 & 2,5 & 2,4 & 2,7 & 2,6 & 3,2 & 3,1 & 3,1 & 3,2 & 3,0 \\
\hline Recreation and culture & 2,2 & 2,2 & 3,1 & 3,1 & 3,6 & 3,9 & 4,2 & 3,8 & 4,3 & 5,6 & 4,6 \\
\hline Audio-visual, photographic and information processing equipment & 1,0 & 1,0 & 1,5 & 1,5 & 1,5 & 1,8 & 2,1 & 1,6 & 1,4 & 1,4 & 1,5 \\
\hline Other major durables for recreation and culture & 0,0 & 0,0 & 0,2 & 0,0 & 0,0 & 0,1 & 0,1 & 0,1 & 0,1 & 0,1 & 0,1 \\
\hline Other recreational items and equipment, garden and pets & 0,1 & 0,1 & 0,2 & 0,2 & 0,2 & 0,3 & 0,3 & 0,4 & 0,8 & 1,3 & 0,8 \\
\hline Recreational and cultural services & 0,5 & 0,5 & 0,6 & 0,6 & 0,7 & 0,8 & 0,9 & 0,9 & 1,1 & 1,8 & 1,3 \\
\hline Newspapers, books and stationery & 0,6 & 0,5 & 0,6 & 0,6 & 0,9 & 0,9 & 0,8 & 0,8 & 0,8 & 0,8 & 0,8 \\
\hline Package holidays & 0,0 & 0,0 & 0,0 & 0,1 & 0,2 & 0,0 & 0,1 & 0,1 & 0,1 & 0,3 & 0,2 \\
\hline
\end{tabular}




\begin{tabular}{|c|c|c|c|c|c|c|c|c|c|c|c|}
\hline & \multicolumn{10}{|c|}{ Income deciles } & \multirow[t]{2}{*}{ Total } \\
\hline & Lower & 2 & 3 & 4 & 5 & 6 & 7 & 8 & 9 & Upper & \\
\hline Education & 2,2 & 1,9 & 1,8 & 2,0 & 2,0 & 1,7 & 2,4 & 3,9 & 2,7 & 2,2 & 2,4 \\
\hline Pre-primary and primary education & 0,5 & 0,5 & 0,5 & 0,6 & 0,5 & 0,4 & 0,6 & 0,7 & 0,7 & 0,6 & 0,6 \\
\hline Secondary education & 0,4 & 0,5 & 0,5 & 0,5 & 0,5 & 0,5 & 0,5 & 0,5 & 0,6 & 0,8 & 0,6 \\
\hline Tertiary education & 1,2 & 0,9 & 0,8 & 0,9 & 0,9 & 0,7 & 1,0 & 0,9 & 1,4 & 0,7 & 0,9 \\
\hline Education not definable by level & 0,0 & 0,1 & 0,1 & 0,1 & 0,1 & 0,0 & 0,3 & 1,7 & 0,1 & 0,1 & 0,2 \\
\hline Restaurants and hotels & 4,2 & 2,3 & 2,2 & 2,1 & 2,3 & 2,7 & 2,6 & 2,0 & 2,1 & 2,1 & 2,2 \\
\hline Catering services & 3,8 & 2,0 & 2,0 & 1,7 & 2,0 & 2,3 & 2,1 & 1,5 & 1,2 & 0,9 & 1,4 \\
\hline Accommodation services & 0,4 & 0,3 & 0,2 & 0,4 & 0,3 & 0,4 & 0,5 & 0,5 & 0,9 & 1,1 & 0,8 \\
\hline Miscellaneous goods and services & 8,2 & 8,3 & 8,7 & 10,7 & 10,3 & 10,7 & 11,5 & 14,3 & 15,4 & 16,5 & 14,4 \\
\hline Personal care & 2,0 & 2,0 & 1,7 & 1,8 & 1,7 & 1,8 & 1,7 & 1,4 & 1,1 & 0,9 & 1,2 \\
\hline Personal effects & 0,4 & 0,4 & 0,4 & 0,4 & 0,5 & 0,4 & 0,5 & 0,4 & 0,5 & 0,5 & 0,5 \\
\hline Social protection & 0,1 & 0,1 & 0,1 & 0,2 & 0,2 & 0,2 & 0,2 & 0,3 & 0,2 & 0,2 & 0,2 \\
\hline Insurance & 1,5 & 1,9 & 2,0 & 2,2 & 2,3 & 2,7 & 3,8 & 7,0 & 9,0 & 11,2 & 8,1 \\
\hline Financial services n.e.c. & 0,8 & 0,6 & 0,8 & 1,5 & 1,0 & 1,3 & 1,4 & 1,4 & 1,7 & 1,5 & 1,4 \\
\hline Other services n.e.c. & 3,4 & 3,4 & 3,6 & 4,7 & 4,5 & 4,4 & 4,1 & 3,7 & 2,9 & 2,2 & 3,0 \\
\hline Other unclassified expenses & 0,2 & 0,2 & 0,2 & 0,2 & 0,3 & 0,3 & 0,3 & 0,3 & 0,3 & 0,3 & 0,3 \\
\hline Total & 100,0 & 100,0 & 100,0 & 100,0 & 100,0 & 100,0 & 100,0 & 100,0 & 100,0 & 100,0 & 100,0 \\
\hline
\end{tabular}

Due to rounding, figures do not necessarily add up to totals

- No expenditure 


\section{Expenditure}

Table 2.15 - Percentage distribution of annual household consumption expenditure by third expenditure group and income deciles

\begin{tabular}{|c|c|c|c|c|c|c|c|c|c|c|c|}
\hline & \multicolumn{10}{|c|}{ Income deciles } & \multirow[t]{2}{*}{ Total } \\
\hline & Lower & 2 & 3 & 4 & 5 & 6 & 7 & 8 & 9 & Upper & \\
\hline Average household size & 2,8 & 3,3 & 3,8 & 4,4 & 4,7 & 4,9 & 4,6 & 4,4 & 3,8 & 3,6 & 3,8 \\
\hline Third expenditure group & \multicolumn{11}{|c|}{ Percentage (\%) } \\
\hline Food and non-alcoholic beverages & 32,8 & 33,2 & 30,9 & 29,7 & 28,9 & 26,1 & 22,2 & 16,8 & 11,1 & 7,3 & 14,4 \\
\hline Bread and cereals & 9,7 & 10,0 & 9,2 & 8,4 & 7,6 & 6,4 & 5,1 & 3,4 & 1,7 & 0,8 & 3,0 \\
\hline Meat & 6,9 & 7,1 & 7,0 & 7,1 & 7,5 & 7,0 & 6,2 & 4,7 & 3,0 & 1,7 & 3,6 \\
\hline Fish & 1,1 & 0,9 & 0,9 & 1,0 & 0,9 & 0,9 & 0,7 & 0,5 & 0,5 & 0,3 & 0,5 \\
\hline Milk, cheese and eggs & 2,8 & 2,7 & 2,5 & 2,5 & 2,5 & 2,3 & 2,1 & 1,7 & 1,3 & 0,8 & 1,4 \\
\hline Oils and fats & 1,4 & 1,4 & 1,2 & 1,2 & 1,1 & 0,9 & 0,8 & 0,5 & 0,3 & 0,2 & 0,5 \\
\hline Fruits & 0,5 & 0,6 & 0,6 & 0,5 & 0,5 & 0,5 & 0,5 & 0,4 & 0,3 & 0,3 & 0,4 \\
\hline Vegetables & 4,1 & 4,2 & 3,5 & 3,2 & 2,9 & 2,5 & 2,0 & 1,5 & 0,9 & 0,6 & 1,4 \\
\hline Sugar, jam, honey, chocolate and confectionery & 1,9 & 2,0 & 1,9 & 1,8 & 1,5 & 1,4 & 1,1 & 0,7 & 0,5 & 0,3 & 0,7 \\
\hline Food products n.e.c. & 1,8 & 1,8 & 1,5 & 1,4 & 1,6 & 1,3 & 1,0 & 0,8 & 0,5 & 0,3 & 0,7 \\
\hline Coffee, tea and cocoa & 0,6 & 0,6 & 0,6 & 0,5 & 0,6 & 0,5 & 0,4 & 0,3 & 0,2 & 0,1 & 0,3 \\
\hline Mineral waters, soft drinks, fruit and vegetable juices & 1,2 & 1,2 & 1,2 & 1,2 & 1,3 & 1,3 & 1,2 & 1,0 & 0,7 & 0,5 & 0,8 \\
\hline Unspecified food & 0,8 & 0,8 & 0,9 & 0,9 & 1,0 & 1,2 & 1,2 & 1,3 & 1,2 & 1,4 & 1,2 \\
\hline Alcoholic beverages and tobacco & 2,1 & 2,2 & 1,7 & 1,8 & 1,8 & 2,1 & 1,9 & 1,4 & 1,0 & 0,7 & 1,2 \\
\hline Spirits & 0,1 & 0,2 & 0,1 & 0,1 & 0,1 & 0,3 & 0,2 & 0,1 & 0,1 & 0,1 & 0,1 \\
\hline Wine & 0,1 & 0,1 & 0,1 & 0,1 & 0,1 & 0,1 & 0,1 & 0,1 & 0,1 & 0,1 & 0,1 \\
\hline Beer & 0,7 & 0,5 & 0,4 & 0,6 & 0,6 & 0,6 & 0,5 & 0,3 & 0,2 & 0,1 & 0,3 \\
\hline Tobacco & 1,2 & 1,4 & 1,2 & 1,0 & 1,1 & 1,1 & 1,2 & 0,9 & 0,6 & 0,4 & 0,7 \\
\hline
\end{tabular}




\begin{tabular}{|c|c|c|c|c|c|c|c|c|c|c|c|}
\hline & \multicolumn{10}{|c|}{ Income deciles } & \multirow[t]{2}{*}{ Total } \\
\hline & Lower & 2 & 3 & 4 & 5 & 6 & 7 & 8 & 9 & Upper & \\
\hline Clothing and footwear & 8,2 & 8,0 & 8,3 & 8,2 & 8,2 & 7,6 & 7,6 & 6,2 & 4,4 & 3,1 & 5,0 \\
\hline Clothing materials & 0,0 & 0,0 & 0,1 & 0,1 & 0,0 & 0,0 & 0,1 & 0,1 & 0,1 & 0,0 & 0,0 \\
\hline Garments & 5,3 & 5,4 & 5,6 & 5,5 & 5,5 & 5,1 & 5,1 & 4,3 & 3,1 & 2,1 & 3,4 \\
\hline Other articles of clothing and clothing accessories & 0,1 & 0,1 & 0,1 & 0,1 & 0,1 & 0,1 & 0,1 & 0,1 & 0,1 & 0,1 & 0,1 \\
\hline Cleaning, repair and hire of clothing & 0,0 & 0,0 & 0,0 & 0,0 & 0,0 & 0,0 & 0,1 & 0,0 & 0,0 & 0,0 & 0,0 \\
\hline Shoes and other footwear & 2,6 & 2,5 & 2,5 & 2,5 & 2,5 & 2,3 & 2,2 & 1,8 & 1,2 & 0,9 & 1,4 \\
\hline Repair and hire of footwear & 0,0 & 0,0 & 0,0 & 0,0 & 0,0 & 0,0 & 0,0 & 0,0 & 0,0 & 0,0 & 0,0 \\
\hline Housing, water, electricity, gas and other fuels & 18,9 & 17,6 & 19,0 & 18,3 & 18,3 & 18,3 & 19,9 & 22,4 & 24,7 & 26,3 & 23,6 \\
\hline Actual rentals paid by tenants & 6,1 & 3,6 & 3,7 & 3,1 & 4,3 & 4,0 & 5,6 & 5,2 & 6,0 & 1,7 & 3,6 \\
\hline Imputed rentals of owner-occupiers & 4,8 & 5,6 & 6,8 & 7,0 & 6,4 & 6,9 & 7,5 & 9,7 & 11,9 & 17,1 & 12,6 \\
\hline Materials for maintenance and repair of the dwelling & 0,2 & 0,3 & 0,3 & 0,5 & 0,3 & 0,4 & 0,3 & 0,4 & 0,4 & 1,0 & 0,7 \\
\hline Service of the maintenance and repair of the dwelling & 0,2 & 0,4 & 0,4 & 0,4 & 0,3 & 0,4 & 0,7 & 0,5 & 0,8 & 1,7 & 1,1 \\
\hline Water and electricity & 0,6 & 0,3 & 0,3 & 0,4 & 0,6 & 1,0 & 0,6 & 1,2 & 1,0 & 1,1 & 0,9 \\
\hline Water supply & 0,6 & 0,6 & 0,8 & 0,8 & 0,7 & 0,7 & 0,6 & 0,8 & 0,8 & 0,5 & 0,6 \\
\hline Refuse collection & 0,3 & 0,3 & 0,3 & 0,2 & 0,3 & 0,3 & 0,3 & 0,3 & 0,2 & 0,1 & 0,2 \\
\hline Sewerage collection & 0,3 & 0,3 & 0,2 & 0,2 & 0,2 & 0,2 & 0,3 & 0,3 & 0,3 & 0,2 & 0,2 \\
\hline Other services relating to the dwelling & 0,6 & 0,5 & 0,7 & 0,7 & 0,6 & 0,7 & 0,9 & 1,2 & 1,2 & 1,5 & 1,2 \\
\hline Electricity & 2,5 & 2,5 & 2,8 & 2,5 & 2,9 & 2,4 & 2,5 & 2,4 & 2,0 & 1,2 & 1,8 \\
\hline Gas & 0,1 & 0,1 & 0,1 & 0,1 & 0,1 & 0,1 & 0,1 & 0,1 & 0,1 & 0,0 & 0,1 \\
\hline Liquid fuels & 1,6 & 1,5 & 1,2 & 1,2 & 0,9 & 0,7 & 0,5 & 0,2 & 0,1 & 0,0 & 0,3 \\
\hline Solid fuels & 1,2 & 1,6 & 1,4 & 1,2 & 0,8 & 0,6 & 0,3 & 0,1 & 0,0 & 0,0 & 0,3 \\
\hline $\begin{array}{l}\text { Furnishings, household equipment and routine maintenance of } \\
\text { the dwelling }\end{array}$ & 6,2 & 7,2 & 8,2 & 8,3 & 7,8 & 8,4 & 7,8 & 7,3 & 5,9 & 6,6 & 6,9 \\
\hline Furniture and furnishings & 0,8 & 1,1 & 1,6 & 1,8 & 1,5 & 1,8 & 2,0 & 1,6 & 1,1 & 1,0 & 1,3 \\
\hline Carpets and other floor covering & 0,1 & 0,1 & 0,1 & 0,1 & 0,1 & 0,1 & 0,1 & 0,2 & 0,1 & 0,2 & 0,2 \\
\hline Repair of furniture, furnishings and floor covering & 0,0 & 0,0 & 0,0 & 0,0 & 0,0 & 0,0 & 0,0 & 0,0 & 0,1 & 0,0 & 0,0 \\
\hline Household textiles & 1,7 & 2,1 & 2,4 & 2,3 & 2,2 & 2,2 & 2,0 & 1,8 & 1,1 & 0,7 & 1,3 \\
\hline Major household appliances & 0,9 & 1,0 & 1,3 & 1,4 & 1,3 & 1,6 & 1,3 & 1,2 & 0,7 & 0,5 & 0,8 \\
\hline Small electrical household appliances & 0,2 & 0,2 & 0,2 & 0,2 & 0,2 & 0,2 & 0,2 & 0,2 & 0,1 & 0,1 & 0,1 \\
\hline
\end{tabular}




\begin{tabular}{|c|c|c|c|c|c|c|c|c|c|c|c|}
\hline & \multicolumn{10}{|c|}{ Income deciles } & \multirow[t]{2}{*}{ Total } \\
\hline & Lower & 2 & 3 & 4 & 5 & 6 & 7 & 8 & 9 & Upper & \\
\hline Repair of household appliances & 0,0 & 0,0 & 0,0 & 0,0 & 0,1 & 0,0 & 0,0 & 0,0 & 0,0 & 0,0 & 0,0 \\
\hline Glassware, tableware and household utensils & 0,3 & 0,3 & 0,3 & 0,3 & 0,3 & 0,3 & 0,3 & 0,2 & 0,2 & 0,1 & 0,2 \\
\hline Major tools and equipment & 0,0 & 0,0 & 0,0 & 0,0 & 0,0 & 0,0 & 0,0 & 0,0 & 0,0 & 0,1 & 0,0 \\
\hline Small tools and miscellaneous accessories & 0,1 & 0,1 & 0,1 & 0,1 & 0,1 & 0,1 & 0,1 & 0,1 & 0,1 & 0,1 & 0,1 \\
\hline Non-durable household goods & 1,9 & 1,9 & 1,8 & 1,6 & 1,5 & 1,4 & 1,2 & 0,9 & 0,6 & 0,5 & 0,8 \\
\hline Domestic services and household arcticles & 0,3 & 0,3 & 0,3 & 0,4 & 0,5 & 0,5 & 0,7 & 1,1 & 1,8 & 3,4 & 2,1 \\
\hline Health & 1,3 & 1,7 & 1,6 & 1,6 & 1,8 & 1,7 & 1,4 & 1,6 & 1,6 & 1,8 & 1,7 \\
\hline Medical products, appliances and equipment & 0,5 & 0,6 & 0,6 & 0,6 & 0,6 & 0,5 & 0,5 & 0,6 & 0,6 & 0,7 & 0,6 \\
\hline Out-patient services & 0,7 & 1,0 & 1,0 & 1,0 & 1,0 & 1,1 & 0,8 & 0,8 & 0,7 & 0,9 & 0,9 \\
\hline Hospital services & 0,1 & 0,0 & 0,0 & 0,0 & 0,2 & 0,1 & 0,1 & 0,2 & 0,3 & 0,2 & 0,2 \\
\hline Transport & 10,5 & 12,3 & 10,9 & 10,9 & 11,4 & 13,2 & 14,3 & 16,4 & 22,9 & 24,0 & 19,9 \\
\hline Motor cars & 2,5 & 4,1 & 3,1 & 2,1 & 2,0 & 3,4 & 3,0 & 6,2 & 13,1 & 16,9 & 11,4 \\
\hline Motorcycles & 0,0 & - & - & - & 0,0 & 0,0 & - & 0,0 & 0,2 & 0,1 & 0,1 \\
\hline Bicycles & 0,0 & 0,0 & 0,0 & 0,1 & 0,0 & 0,0 & 0,0 & 0,0 & 0,0 & 0,0 & 0,0 \\
\hline Animal-drawn vehicles & 0,0 & 0,0 & 0,0 & 0,0 & 0,0 & 0,0 & 0,0 & 0,0 & - & 0,0 & 0,0 \\
\hline Spare parts and accessories & 0,1 & 0,1 & 0,1 & 0,2 & 0,2 & 0,4 & 0,5 & 0,6 & 1,0 & 0,6 & 0,6 \\
\hline Fuels and lubricants & 0,8 & 0,4 & 0,5 & 0,6 & 0,7 & 1,7 & 2,4 & 3,4 & 5,0 & 4,1 & 3,5 \\
\hline Maintenance and repair of personal transport equipment & 0,1 & 0,0 & 0,0 & 0,1 & 0,1 & 0,2 & 0,3 & 0,4 & 0,6 & 0,6 & 0,5 \\
\hline Other services in respect of personal transport equipment & 0,2 & 0,3 & 0,2 & 0,3 & 0,5 & 0,4 & 0,5 & 0,6 & 0,7 & 0,6 & 0,5 \\
\hline Passenger transport by rail & 0,5 & 0,5 & 0,3 & 0,3 & 0,5 & 0,4 & 0,5 & 0,2 & 0,1 & 0,0 & 0,2 \\
\hline Passenger transport by road & 6,3 & 6,8 & 6,7 & 7,1 & 7,2 & 6,7 & 7,2 & 4,8 & 2,0 & 0,5 & 2,9 \\
\hline Passenger transport by air & 0,0 & 0,0 & 0,0 & 0,0 & 0,0 & 0,0 & 0,0 & 0,1 & 0,3 & 0,5 & 0,3 \\
\hline
\end{tabular}




\begin{tabular}{|c|c|c|c|c|c|c|c|c|c|c|c|}
\hline & \multicolumn{10}{|c|}{ Income deciles } & \multirow[t]{2}{*}{ Total } \\
\hline & Lower & 2 & 3 & 4 & 5 & 6 & 7 & 8 & 9 & Upper & \\
\hline Passenger transport by sea and inland waterway & - & 0,0 & - & 0,0 & - & - & 0,0 & 0,0 & 0,0 & 0,0 & 0,0 \\
\hline Other puchased transport services & 0,0 & 0,1 & 0,0 & 0,0 & 0,0 & 0,1 & 0,1 & 0,0 & 0,0 & 0,0 & 0,0 \\
\hline Cost for other modes of transport & 0,0 & 0,0 & 0,0 & 0,0 & 0,0 & 0,0 & 0,0 & 0,0 & 0,0 & 0,0 & 0,0 \\
\hline Communication & 3,0 & 2,9 & 3,3 & 3,2 & 3,5 & 3,4 & 3,9 & 3,7 & 3,6 & 3,5 & 3,5 \\
\hline Postal services & 0,0 & 0,0 & 0,0 & 0,0 & 0,0 & 0,0 & 0,1 & 0,1 & 0,1 & 0,1 & 0,1 \\
\hline Telephone and telefax equipment & 0,7 & 0,7 & 0,7 & 0,7 & 0,8 & 0,7 & 0,7 & 0,6 & 0,4 & 0,2 & 0,4 \\
\hline Telephone and telefax services & 2,2 & 2,2 & 2,5 & 2,4 & 2,7 & 2,6 & 3,2 & 3,1 & 3,1 & 3,2 & 3,0 \\
\hline Recreation and culture & 2,2 & 2,2 & 3,1 & 3,1 & 3,6 & 3,9 & 4,2 & 3,8 & 4,3 & 5,6 & 4,6 \\
\hline Audio-visual, photographic and information processing equipment & 1,0 & 1,0 & 1,5 & 1,5 & 1,5 & 1,8 & 2,1 & 1,6 & 1,4 & 1,4 & 1,5 \\
\hline Other major durables for recreation and culture & 0,0 & 0,0 & 0,2 & 0,0 & 0,0 & 0,1 & 0,1 & 0,1 & 0,1 & 0,1 & 0,1 \\
\hline Other recreational items and equipment, garden and pets & 0,1 & 0,1 & 0,2 & 0,2 & 0,2 & 0,3 & 0,3 & 0,4 & 0,8 & 1,3 & 0,8 \\
\hline Recreational and cultural services & 0,5 & 0,5 & 0,6 & 0,6 & 0,7 & 0,8 & 0,9 & 0,9 & 1,1 & 1,8 & 1,3 \\
\hline Newspapers, books and stationery & 0,6 & 0,5 & 0,6 & 0,6 & 0,9 & 0,9 & 0,8 & 0,8 & 0,8 & 0,8 & 0,8 \\
\hline Package holidays & 0,0 & 0,0 & 0,0 & 0,1 & 0,2 & 0,0 & 0,1 & 0,1 & 0,1 & 0,3 & 0,2 \\
\hline Education & 2,2 & 1,9 & 1,8 & 2,0 & 2,0 & 1,7 & 2,4 & 3,9 & 2,7 & 2,2 & 2,4 \\
\hline Pre-primary and primary education & 0,5 & 0,5 & 0,5 & 0,6 & 0,5 & 0,4 & 0,6 & 0,7 & 0,7 & 0,6 & 0,6 \\
\hline Secondary education & 0,4 & 0,5 & 0,5 & 0,5 & 0,5 & 0,5 & 0,5 & 0,5 & 0,6 & 0,8 & 0,6 \\
\hline Tertiary education & 1,2 & 0,9 & 0,8 & 0,9 & 0,9 & 0,7 & 1,0 & 0,9 & 1,4 & 0,7 & 0,9 \\
\hline Education not definable by level & 0,0 & 0,1 & 0,1 & 0,1 & 0,1 & 0,0 & 0,3 & 1,7 & 0,1 & 0,1 & 0,2 \\
\hline Restaurants and hotels & 4,2 & 2,3 & 2,2 & 2,1 & 2,3 & 2,7 & 2,6 & 2,0 & 2,1 & 2,1 & 2,2 \\
\hline Beverages in restaurants, cafes, canteens and the like & 1,2 & 0,9 & 0,8 & 0,8 & 0,7 & 0,9 & 0,8 & 0,5 & 0,2 & 0,1 & 0,4 \\
\hline Meals in restaurants, cafes, canteens and the like & 2,6 & 1,1 & 1,2 & 1,0 & 1,3 & 1,4 & 1,3 & 1,1 & 1,0 & 0,8 & 1,0 \\
\hline Accommodation services & 0,4 & 0,3 & 0,2 & 0,4 & 0,3 & 0,4 & 0,5 & 0,5 & 0,9 & 1,1 & 0,8 \\
\hline
\end{tabular}




\begin{tabular}{|c|c|c|c|c|c|c|c|c|c|c|c|}
\hline & \multicolumn{10}{|c|}{ Income deciles } & \multirow[t]{2}{*}{ Total } \\
\hline & Lower & 2 & 3 & 4 & 5 & 6 & 7 & 8 & 9 & Upper & \\
\hline Miscellaneous goods and services & 8,2 & 8,3 & 8,7 & 10,7 & 10,3 & 10,7 & 11,5 & 14,3 & 15,4 & 16,5 & 14,4 \\
\hline Hairdressing salons and personal grooming establishments & 0,0 & 0,0 & 0,0 & 0,1 & 0,0 & 0,1 & 0,0 & 0,1 & 0,1 & 0,1 & 0,1 \\
\hline Electrical appliances for personal care & 0,0 & 0,0 & 0,0 & 0,0 & 0,0 & 0,0 & 0,0 & 0,0 & 0,0 & 0,0 & 0,0 \\
\hline Other appliances, articles and products for personal care & 1,9 & 2,0 & 1,7 & 1,8 & 1,7 & 1,7 & 1,6 & 1,3 & 1,0 & 0,8 & 1,2 \\
\hline Jewellery, clocks and watches & 0,2 & 0,1 & 0,1 & 0,1 & 0,2 & 0,2 & 0,2 & 0,2 & 0,2 & 0,3 & 0,3 \\
\hline Other personal effects & 0,2 & 0,2 & 0,2 & 0,3 & 0,3 & 0,2 & 0,2 & 0,2 & 0,2 & 0,2 & 0,2 \\
\hline Social protection services & 0,1 & 0,1 & 0,1 & 0,2 & 0,2 & 0,2 & 0,2 & 0,3 & 0,2 & 0,2 & 0,2 \\
\hline Insurance connected with the dwelling & 0,1 & 0,1 & 0,1 & 0,2 & 0,1 & 0,3 & 0,5 & 1,6 & 2,2 & 4,8 & 2,8 \\
\hline Insurance connected with health & 0,3 & 0,3 & 0,1 & 0,1 & 0,2 & 0,5 & 1,3 & 3,3 & 4,6 & 4,7 & 3,4 \\
\hline Insurance connected with transport & 0,0 & 0,0 & 0,0 & 0,0 & 0,0 & 0,1 & 0,1 & 0,4 & 1,1 & 1,3 & 0,8 \\
\hline Other insurance & 1,1 & 1,6 & 1,8 & 1,8 & 1,9 & 1,9 & 1,8 & 1,8 & 1,2 & 0,5 & 1,1 \\
\hline Financial services n.e.c. & 0,8 & 0,6 & 0,8 & 1,5 & 1,0 & 1,3 & 1,4 & 1,4 & 1,7 & 1,5 & 1,4 \\
\hline Other services & 3,4 & 3,4 & 3,6 & 4,7 & 4,5 & 4,4 & 4,1 & 3,7 & 2,9 & 2,2 & 3,0 \\
\hline Other unclassified expenses & 0,2 & 0,2 & 0,2 & 0,2 & 0,3 & 0,3 & 0,3 & 0,3 & 0,3 & 0,3 & 0,3 \\
\hline Total & 100,0 & 100,0 & 100,0 & 100,0 & 100,0 & 100,0 & 100,0 & 100,0 & 100,0 & 100,0 & 100,0 \\
\hline
\end{tabular}

Due to rounding, figures do not necessarily add up to totals

- No expenditure 


\section{Expenditure}

Table 2.16 - Percentage distribution of annual household consumption expenditure by main expenditure group and province

\begin{tabular}{|c|c|c|c|c|c|c|c|c|c|c|}
\hline & $\begin{array}{r}\text { Western } \\
\text { Cape }\end{array}$ & \begin{tabular}{r|} 
Eastern \\
Cape
\end{tabular} & $\begin{array}{r}\text { Northern } \\
\text { Cape }\end{array}$ & \begin{tabular}{r|} 
Free \\
State
\end{tabular} & $\begin{array}{r}\text { KwaZulu- } \\
\text { Natal }\end{array}$ & North West & Gauteng & Mpumalanga & Limpopo & Total \\
\hline Number of households in sample & 2404 & 2825 & 1726 & 1754 & 4732 & 1569 & 2496 & 1687 & 1951 & 21144 \\
\hline Number of households in population & 1271541 & 1723789 & 293306 & 899152 & 2214405 & 907475 & 2967693 & 879707 & 1300512 & 12457580 \\
\hline Main expenditure group & \multicolumn{10}{|c|}{ Percentage (\%) } \\
\hline Food and non-alcoholic beverages & 12,6 & 17,8 & 16,1 & 13,0 & 16,9 & 15,0 & 12,0 & 16,3 & 22,1 & 14,4 \\
\hline Alcoholic beverages and tobacco & 1,3 & 1,4 & 1,8 & 1,1 & 0,9 & 1,2 & 1,1 & 1,0 & 1,0 & 1,2 \\
\hline Clothing and footwear & 3,5 & 5,7 & 5,8 & 5,8 & 5,6 & 5,3 & 4,7 & 5,6 & 6,7 & 5,0 \\
\hline Housing, water, electricity, gas and other fuels & 28,6 & 21,4 & 20,5 & 19,8 & 22,8 & 19,8 & 24,8 & 17,6 & 19,9 & 23,6 \\
\hline $\begin{array}{l}\text { Furnishings, household equipment and routine maintenance } \\
\text { of the dwelling }\end{array}$ & 5,2 & 7,3 & 8,6 & 8,3 & 7,2 & 8,2 & 6,4 & 9,2 & 8,8 & 6,9 \\
\hline Health & 1,4 & 1,6 & 1,6 & 2,3 & 1,7 & 1,7 & 1,8 & 1,4 & 1,4 & 1,7 \\
\hline Transport & 21,5 & 19,1 & 19,0 & 21,4 & 18,4 & 17,8 & 20,6 & 21,7 & 14,5 & 19,9 \\
\hline Communication & 3,7 & 3,3 & 3,6 & 3,6 & 4,0 & 3,7 & 3,3 & 3,4 & 3,1 & 3,5 \\
\hline Recreation and culture & 5,3 & 3,4 & 4,4 & 4,5 & 4,6 & 4,0 & 4,9 & 4,3 & 3,6 & 4,6 \\
\hline Education & 1,9 & 2,0 & 1,2 & 2,5 & 2,6 & 3,7 & 2,4 & 2,4 & 3,2 & 2,4 \\
\hline Restaurants and hotels & 2,3 & 1,8 & 2,7 & 2,5 & 1,6 & 1,9 & 2,4 & 1,7 & 3,0 & 2,2 \\
\hline Miscellaneous goods and services & 12,1 & 15,2 & 14,7 & 15,0 & 13,4 & 17,6 & 15,4 & 15,4 & 12,3 & 14,4 \\
\hline Other unclassified expenses & 0,6 & 0,2 & 0,1 & 0,1 & 0,4 & 0,1 & 0,2 & 0,1 & 0,5 & 0,3 \\
\hline Total & 100,0 & 100,0 & 100,0 & 100,0 & 100,0 & 100,0 & 100,0 & 100,0 & 100,0 & 100,0 \\
\hline
\end{tabular}

Due to rounding, figures do not necessarily add up to totals 


\section{Expenditure}

Table 2.17 - Percentage distribution of annual household consumption expenditure by secondary expenditure group and province

\begin{tabular}{|c|c|c|c|c|c|c|c|c|c|c|}
\hline & \begin{tabular}{r|} 
Western \\
Cape
\end{tabular} & \begin{tabular}{r|} 
Eastern \\
Cape
\end{tabular} & \begin{tabular}{r|} 
Northern \\
Cape
\end{tabular} & \begin{tabular}{r|} 
Free \\
State
\end{tabular} & $\begin{array}{r}\text { KwaZulu- } \\
\text { Natal }\end{array}$ & \begin{tabular}{r|r} 
North \\
West
\end{tabular} & Gauteng & Mpumalanga & Limpopo & Total \\
\hline $\begin{array}{l}\text { Number of households in sample } \\
\text { Number of households in population }\end{array}$ & $\begin{array}{r}2404 \\
1271541 \\
\end{array}$ & $\begin{array}{r}2825 \\
1723789 \\
\end{array}$ & $\begin{array}{r}1726 \\
293306 \\
\end{array}$ & $\begin{array}{r}1754 \\
899152 \\
\end{array}$ & $\begin{array}{r}4732 \\
2214405 \\
\end{array}$ & $\begin{array}{r}1569 \\
907475 \\
\end{array}$ & $\begin{array}{r}2496 \\
2967693 \\
\end{array}$ & $\begin{array}{r}1687 \\
879707 \\
\end{array}$ & $\begin{array}{r}1951 \\
1300512 \\
\end{array}$ & $\begin{array}{r}21144 \\
12457580 \\
\end{array}$ \\
\hline Secondary expenditure group & \multicolumn{10}{|c|}{ Percentage (\%) } \\
\hline Food and non-alcoholic beverages & 12,6 & 17,8 & 16,1 & 13,0 & 16,9 & 15,0 & 12,0 & 16,3 & 22,1 & 14,4 \\
\hline Food & 9,2 & 15,9 & 14,4 & 11,5 & 14,5 & 13,4 & 10,0 & 14,6 & 18,7 & 12,2 \\
\hline Non-alcoholic beverages & 0,9 & 1,1 & 1,2 & 1,0 & 0,9 & 1,2 & 1,1 & 1,2 & 1,4 & 1,1 \\
\hline Unspecified food & 2,5 & 0,8 & 0,5 & 0,5 & 1,4 & 0,4 & 0,9 & 0,5 & 2,0 & 1,2 \\
\hline Alcoholic beverages and tobacco & 1,3 & 1,4 & 1,8 & 1,1 & 0,9 & 1,2 & 1,1 & 1,0 & 1,0 & 1,2 \\
\hline Alcoholic beverages & 0,5 & 0,5 & 0,5 & 0,4 & 0,4 & 0,6 & 0,5 & 0,4 & 0,5 & 0,5 \\
\hline Tobacco & 0,8 & 0,8 & 1,3 & 0,8 & 0,5 & 0,7 & 0,6 & 0,6 & 0,5 & 0,7 \\
\hline Clothing and footwear & 3,5 & 5,7 & 5,8 & 5,8 & 5,6 & 5,3 & 4,7 & 5,6 & 6,7 & 5,0 \\
\hline Clothing & 2,5 & 4,0 & 4,3 & 4,1 & 3,9 & 3,8 & 3,2 & 4,0 & 4,8 & 3,5 \\
\hline Footwear & 1,0 & 1,7 & 1,5 & 1,7 & 1,6 & 1,5 & 1,4 & 1,6 & 1,9 & 1,5 \\
\hline Housing, water, electricity, gas and other fuels & 28,6 & 21,4 & 20,5 & 19,8 & 22,8 & 19,8 & 24,8 & 17,6 & 19,9 & 23,6 \\
\hline Actual rentals for housing & 4,0 & 2,8 & 2,8 & 2,9 & 3,3 & 5,6 & 3,8 & 2,5 & 3,1 & 3,6 \\
\hline Imputed rentals for housing & 17,2 & 11,0 & 8,6 & 8,8 & 11,1 & 7,8 & 13,9 & 8,9 & 10,6 & 12,6 \\
\hline Maintenance and repair of the dwelling & 2,9 & 2,2 & 1,5 & 1,4 & 1,2 & 1,0 & 1,7 & 1,1 & 1,0 & 1,7 \\
\hline $\begin{array}{l}\text { Water supply and miscellaneous services relating to the } \\
\text { dwelling }\end{array}$ & 2,5 & 2,1 & 4,1 & 3,6 & 4,4 & 2,4 & 3,9 & 2,2 & 1,5 & 3,2 \\
\hline Electricity, gas and other fuels & 2,1 & 3,3 & 3,4 & 3,2 & 2,8 & 3,1 & 1,7 & 2,9 & 3,8 & 2,4 \\
\hline
\end{tabular}




\begin{tabular}{|c|c|c|c|c|c|c|c|c|c|c|}
\hline & \begin{tabular}{r|} 
Western \\
Cape
\end{tabular} & \begin{tabular}{r|} 
Eastern \\
Cape
\end{tabular} & \begin{tabular}{r|} 
Northern \\
Cape
\end{tabular} & \begin{tabular}{l|} 
Free \\
State
\end{tabular} & $\begin{array}{r}\text { KwaZulu- } \\
\text { Natal }\end{array}$ & \begin{tabular}{r|r} 
North \\
West
\end{tabular} & Gauteng & Mpumalanga & Limpopo & Total \\
\hline $\begin{array}{l}\text { Furnishings, household equipment and routine } \\
\text { maintenance of the dwelling }\end{array}$ & 5,2 & 7,3 & 8,6 & 8,3 & 7,2 & 8,2 & 6,4 & 9,2 & 8,8 & 6,9 \\
\hline Furniture and furnishings, carpets and other floor covering & 1,0 & 1,6 & 1,8 & 1,9 & 1,5 & 1,6 & 1,3 & 2,2 & 2,1 & 1,5 \\
\hline Household textiles & 0,8 & 1,7 & 2,0 & 1,7 & 1,3 & 1,6 & 1,0 & 2,2 & 2,1 & 1,3 \\
\hline Household appliances & 0,8 & 1,1 & 1,7 & 1,2 & 1,1 & 1,1 & 0,8 & 1,4 & 1,5 & 1,0 \\
\hline Glassware, tableware and household utensils & 0,1 & 0,3 & 0,2 & 0,3 & 0,2 & 0,2 & 0,2 & 0,3 & 0,3 & 0,2 \\
\hline Tools and equipment for house and garden & 0,1 & 0,1 & 0,2 & 0,1 & 0,1 & 0,1 & 0,1 & 0,1 & 0,1 & 0,1 \\
\hline Goods and services for routine household maintenance & 2,4 & 2,4 & 2,7 & 3,1 & 3,0 & 3,6 & 3,1 & 3,0 & 2,6 & 2,9 \\
\hline Health & 1,4 & 1,6 & 1,6 & 2,3 & 1,7 & 1,7 & 1,8 & 1,4 & 1,4 & 1,7 \\
\hline Medical products, appliances and equipment & 0,6 & 0,7 & 0,6 & 1,0 & 0,6 & 0,7 & 0,6 & 0,5 & 0,5 & 0,6 \\
\hline Out-patient services & 0,7 & 0,8 & 0,7 & 0,9 & 0,9 & 0,8 & 1,0 & 0,8 & 0,8 & 0,9 \\
\hline Hospital services & 0,1 & 0,1 & 0,4 & 0,4 & 0,2 & 0,1 & 0,3 & 0,1 & 0,1 & 0,2 \\
\hline Transport & 21,5 & 19,1 & 19,0 & 21,4 & 18,4 & 17,8 & 20,6 & 21,7 & 14,5 & 19,9 \\
\hline Purchase of vehicles & 14,7 & 10,6 & 11,4 & 12,8 & 9,1 & 8,5 & 11,6 & 14,3 & 5,9 & 11,5 \\
\hline Operation of personal transport equipment & 5,0 & 4,4 & 5,1 & 5,3 & 5,0 & 5,6 & 5,4 & 3,8 & 4,4 & 5,0 \\
\hline Transport services & 1,7 & 4,0 & 2,5 & 3,2 & 4,3 & 3,8 & 3,7 & 3,6 & 4,2 & 3,4 \\
\hline Operational values of other modes of transport & 0,0 & 0,0 & 0,0 & 0,0 & 0,0 & 0,0 & 0,0 & 0,0 & 0,0 & 0,0 \\
\hline Communication & 3,7 & 3,3 & 3,6 & 3,6 & 4,0 & 3,7 & 3,3 & 3,4 & 3,1 & 3,5 \\
\hline Postal services & 0,0 & 0,1 & 0,1 & 0,1 & 0,1 & 0,1 & 0,1 & 0,1 & 0,1 & 0,1 \\
\hline Telephone and telefax equipment & 0,3 & 0,6 & 0,5 & 0,5 & 0,5 & 0,4 & 0,3 & 0,6 & 0,8 & 0,4 \\
\hline Telephone and telefax services & 3,4 & 2,7 & 3,0 & 3,0 & 3,4 & 3,2 & 2,9 & 2,6 & 2,3 & 3,0 \\
\hline Recreation and culture & 5,3 & 3,4 & 4,4 & 4,5 & 4,6 & 4,0 & 4,9 & 4,3 & 3,6 & 4,6 \\
\hline $\begin{array}{l}\text { Audio-visual, photographic and information processing } \\
\text { equipment }\end{array}$ & 1,5 & 1,3 & 1,9 & 1,7 & 1,5 & 1,5 & 1,3 & 1,9 & 1,8 & 1,5 \\
\hline Other major durables for recreation and culture & 0,1 & 0,0 & 0,2 & 0,1 & 0,0 & 0,1 & 0,1 & 0,3 & 0,1 & 0,1 \\
\hline Other recreational items and equipment, garden and pets & 1,3 & 0,5 & 0,6 & 0,7 & 0,7 & 0,7 & 0,9 & 0,5 & 0,4 & 0,8 \\
\hline Recreational and cultural services & 1,6 & 0,7 & 1,0 & 1,2 & 1,0 & 1,0 & 1,6 & 1,0 & 0,7 & 1,3 \\
\hline Newspapers, books and stationery & 0,8 & 0,7 & 0,6 & 0,7 & 0,8 & 0,7 & 0,9 & 0,6 & 0,6 & 0,8 \\
\hline Package holidays & 0,2 & 0,1 & 0,0 & 0,1 & 0,5 & 0,0 & 0,2 & 0,0 & 0,0 & 0,2 \\
\hline
\end{tabular}




\begin{tabular}{|c|c|c|c|c|c|c|c|c|c|c|}
\hline & $\begin{array}{r}\text { Western } \\
\text { Cape }\end{array}$ & $\begin{array}{r}\text { Eastern } \\
\text { Cape }\end{array}$ & \begin{tabular}{r|} 
Northern \\
Cape
\end{tabular} & \begin{tabular}{c|} 
Free \\
State
\end{tabular} & $\begin{array}{r}\text { KwaZulu- } \\
\text { Natal }\end{array}$ & \begin{tabular}{c|} 
North \\
West
\end{tabular} & Gauteng & Mpumalanga & Limpopo & Total \\
\hline Education & 1,9 & 2,0 & 1,2 & 2,5 & 2,6 & 3,7 & 2,4 & 2,4 & 3,2 & 2,4 \\
\hline Pre-primary and primary education & 0,6 & 0,7 & 0,4 & 0,4 & 0,6 & 0,5 & 0,7 & 0,5 & 0,7 & 0,6 \\
\hline Secondary education & 0,5 & 0,5 & 0,3 & 0,5 & 0,7 & 0,6 & 0,7 & 1,2 & 0,8 & 0,6 \\
\hline Tertiary education & 0,8 & 0,6 & 0,4 & 1,0 & 1,2 & 2,5 & 0,7 & 0,6 & 1,6 & 0,9 \\
\hline Education not definable by level & 0,1 & 0,2 & 0,0 & 0,7 & 0,1 & 0,1 & 0,4 & 0,1 & 0,1 & 0,2 \\
\hline Restaurants and hotels & 2,3 & 1,8 & 2,7 & 2,5 & 1,6 & 1,9 & 2,4 & 1,7 & 3,0 & 2,2 \\
\hline Catering services & 1,6 & 1,3 & 1,9 & 1,7 & 0,9 & 1,2 & 1,4 & 0,9 & 2,0 & 1,4 \\
\hline Accommodation services & 0,7 & 0,5 & 0,8 & 0,8 & 0,8 & 0,7 & 1,0 & 0,8 & 0,9 & 0,8 \\
\hline Miscellaneous goods and services & 12,1 & 15,2 & 14,7 & 15,0 & 13,4 & 17,6 & 15,4 & 15,4 & 12,3 & 14,4 \\
\hline Personal care & 1,3 & 1,0 & 1,5 & 1,3 & 1,0 & 1,3 & 1,4 & 1,2 & 1,3 & 1,2 \\
\hline Personal effects & 0,4 & 0,4 & 0,4 & 0,6 & 0,6 & 0,4 & 0,4 & 0,4 & 0,5 & 0,5 \\
\hline Social protection & 0,2 & 0,2 & 0,1 & 0,2 & 0,1 & 0,2 & 0,3 & 0,2 & 0,1 & 0,2 \\
\hline Insurance & 6,9 & 7,7 & 7,8 & 8,5 & 6,5 & 9,5 & 9,6 & 8,5 & 5,4 & 8,1 \\
\hline Financial services n.e.c. & 1,0 & 1,7 & 1,5 & 1,2 & 1,3 & 3,3 & 1,2 & 2,0 & 1,2 & 1,4 \\
\hline Other services n.e.c. & 2,2 & 4,2 & 3,4 & 3,4 & 3,9 & 3,0 & 2,4 & 3,1 & 3,9 & 3,0 \\
\hline Other unclassified expenses & 0,6 & 0,2 & 0,1 & 0,1 & 0,4 & 0,1 & 0,2 & 0,1 & 0,5 & 0,3 \\
\hline Total & 100,0 & 100,0 & 100,0 & 100,0 & 100,0 & 100,0 & 100,0 & 100,0 & 100,0 & 100,0 \\
\hline
\end{tabular}

Due to rounding, figures do not necessarily add up to totals 


\section{Expenditure}

Table 2.18 - Percentage distribution of annual household consumption expenditure by third expenditure group and province

\begin{tabular}{|c|c|c|c|c|c|c|c|c|c|c|}
\hline & $\begin{array}{r}\text { Western } \\
\text { Cape }\end{array}$ & \begin{tabular}{r|} 
Eastern \\
Cape
\end{tabular} & $\begin{array}{r}\text { Northern } \\
\text { Cape }\end{array}$ & \begin{tabular}{r|} 
Free \\
State
\end{tabular} & $\begin{array}{r}\text { KwaZulu- } \\
\text { Natal }\end{array}$ & \begin{tabular}{l|} 
North \\
West
\end{tabular} & Gauteng & Mpumalanga & Limpopo & Total \\
\hline $\begin{array}{l}\text { Number of households in sample } \\
\text { Number of households in population }\end{array}$ & $\begin{array}{r}2404 \\
1271541 \\
\end{array}$ & $\begin{array}{r}2825 \\
1723789 \\
\end{array}$ & $\begin{array}{r}1726 \\
293306 \\
\end{array}$ & $\begin{array}{r}1754 \\
899152 \\
\end{array}$ & $\begin{array}{r}4732 \\
2214405 \\
\end{array}$ & $\begin{array}{r}1569 \\
907475 \\
\end{array}$ & $\begin{array}{r}2496 \\
2967693 \\
\end{array}$ & $\begin{array}{r}1687 \\
879707 \\
\end{array}$ & $\begin{array}{r}1951 \\
1300512 \\
\end{array}$ & $\begin{array}{r}21144 \\
12457580 \\
\end{array}$ \\
\hline Third expenditure group & \multicolumn{10}{|c|}{ Percentage (\%) } \\
\hline Food and non-alcoholic beverages & 12,6 & 17,8 & 16,1 & 13,0 & 16,9 & 15,0 & 12,0 & 16,3 & 22,1 & 14,4 \\
\hline Bread and cereals & 1,6 & 4,5 & 2,8 & 2,6 & 4,3 & 3,1 & 2,1 & 4,0 & 6,7 & 3,0 \\
\hline Meat & 3,0 & 4,0 & 5,3 & 3,6 & 3,9 & 4,1 & 3,3 & 4,3 & 4,9 & 3,6 \\
\hline Fish & 0,5 & 0,4 & 0,6 & 0,5 & 0,3 & 0,5 & 0,5 & 1,0 & 0,8 & 0,5 \\
\hline Milk, cheese and eggs & 1,2 & 1,8 & 1,3 & 1,4 & 1,4 & 1,7 & 1,3 & 1,4 & 1,6 & 1,4 \\
\hline Oils and fats & 0,3 & 0,7 & 0,5 & 0,4 & 0,8 & 0,5 & 0,4 & 0,6 & 0,7 & 0,5 \\
\hline Fruits & 0,4 & 0,4 & 0,3 & 0,4 & 0,4 & 0,4 & 0,3 & 0,4 & 0,6 & 0,4 \\
\hline Vegetables & 1,1 & 2,0 & 1,3 & 1,3 & 1,8 & 1,5 & 1,0 & 1,5 & 1,9 & 1,4 \\
\hline Sugar, jam, honey, chocolate and confectionery & 0,6 & 1,3 & 1,1 & 0,8 & 0,9 & 0,8 & 0,5 & 0,8 & 0,9 & 0,7 \\
\hline Food products n.e.c. & 0,5 & 0,9 & 1,1 & 0,6 & 0,8 & 0,8 & 0,7 & 0,7 & 0,8 & 0,7 \\
\hline Coffee, tea and cocoa & 0,3 & 0,3 & 0,5 & 0,3 & 0,2 & 0,4 & 0,2 & 0,3 & 0,3 & 0,3 \\
\hline Mineral waters, soft drinks, fruit and vegetable juices & 0,7 & 0,8 & 0,8 & 0,8 & 0,7 & 0,9 & 0,9 & 0,9 & 1,1 & 0,8 \\
\hline Unspecified food & 2,5 & 0,8 & 0,5 & 0,5 & 1,4 & 0,4 & 0,9 & 0,5 & 2,0 & 1,2 \\
\hline Alcoholic beverages and tobacco & 1,3 & 1,4 & 1,8 & 1,1 & 0,9 & 1,2 & 1,1 & 1,0 & 1,0 & 1,2 \\
\hline Spirits & 0,2 & 0,2 & 0,1 & 0,1 & 0,1 & 0,1 & 0,1 & 0,1 & 0,0 & 0,1 \\
\hline Wine & 0,2 & 0,1 & 0,2 & 0,1 & 0,1 & 0,1 & 0,1 & 0,0 & 0,0 & 0,1 \\
\hline Beer & 0,1 & 0,2 & 0,2 & 0,2 & 0,2 & 0,4 & 0,3 & 0,3 & 0,4 & 0,3 \\
\hline Tobacco & 0,8 & 0,8 & 1,3 & 0,8 & 0,5 & 0,7 & 0,6 & 0,6 & 0,5 & 0,7 \\
\hline
\end{tabular}




\begin{tabular}{|c|c|c|c|c|c|c|c|c|c|c|}
\hline & $\begin{array}{r}\text { Western } \\
\text { Cape }\end{array}$ & $\begin{array}{r}\text { Eastern } \\
\text { Cape }\end{array}$ & $\begin{array}{r}\text { Northern } \\
\text { Cape }\end{array}$ & \begin{tabular}{r|} 
Free \\
State
\end{tabular} & $\begin{array}{r}\text { KwaZulu- } \\
\text { Natal }\end{array}$ & $\begin{array}{l}\text { North } \\
\text { West }\end{array}$ & Gauteng & Mpumalanga & Limpopo & Total \\
\hline Clothing and footwear & 3,5 & 5,7 & 5,8 & 5,8 & 5,6 & 5,3 & 4,7 & 5,6 & 6,7 & 5,0 \\
\hline Clothing materials & 0,0 & 0,1 & 0,1 & 0,1 & 0,1 & 0,1 & 0,0 & 0,1 & 0,1 & 0,0 \\
\hline Garments & 2,5 & 3,8 & 4,1 & 3,9 & 3,7 & 3,6 & 3,1 & 3,9 & 4,6 & 3,4 \\
\hline Other articles of clothing and clothing accessories & 0,0 & 0,1 & 0,1 & 0,1 & 0,1 & 0,1 & 0,1 & 0,1 & 0,1 & 0,1 \\
\hline Cleaning, repair and hire of clothing & 0,0 & 0,0 & 0,0 & 0,0 & 0,0 & 0,0 & 0,0 & 0,0 & 0,0 & 0,0 \\
\hline Shoes and other footwear & 1,0 & 1,7 & 1,5 & 1,7 & 1,6 & 1,5 & 1,4 & 1,6 & 1,9 & 1,4 \\
\hline Repair and hire of footwear & 0,0 & 0,0 & 0,0 & 0,0 & 0,0 & 0,0 & 0,0 & 0,0 & 0,0 & 0,0 \\
\hline Housing, water, electricity, gas and other fuels & 28,6 & 21,4 & 20,5 & 19,8 & 22,8 & 19,8 & 24,8 & 17,6 & 19,9 & 23,6 \\
\hline Actual rentals paid by tenants & 4,0 & 2,8 & 2,8 & 2,9 & 3,3 & 5,6 & 3,8 & 2,5 & 3,1 & 3,6 \\
\hline Imputed rentals of owner-occupiers & 17,2 & 11,0 & 8,6 & 8,8 & 11,1 & 7,8 & 13,9 & 8,9 & 10,6 & 12,6 \\
\hline Materials for maintenance and repair of the dwelling & 0,6 & 0,8 & 0,5 & 0,5 & 0,6 & 0,4 & 0,9 & 0,5 & 0,4 & 0,7 \\
\hline Service of the maintenance and repair of the dwelling & 2,3 & 1,4 & 1,0 & 0,9 & 0,7 & 0,6 & 0,8 & 0,6 & 0,6 & 1,1 \\
\hline Water and electricity & 0,2 & 0,3 & 1,1 & 0,3 & 2,3 & 0,3 & 1,4 & 0,5 & 0,6 & 0,9 \\
\hline Water supply & 0,6 & 0,5 & 0,8 & 1,0 & 0,6 & 0,8 & 0,7 & 0,3 & 0,5 & 0,6 \\
\hline Refuse collection & 0,3 & 0,2 & 0,4 & 0,4 & 0,1 & 0,2 & 0,2 & 0,2 & 0,1 & 0,2 \\
\hline Sewerage collection & 0,2 & 0,2 & 0,4 & 0,6 & 0,1 & 0,2 & 0,3 & 0,1 & 0,1 & 0,2 \\
\hline Other services relating to the dwelling & 1,2 & 1,0 & 1,4 & 1,3 & 1,4 & 0,9 & 1,4 & 1,1 & 0,3 & 1,2 \\
\hline Electricity & 1,9 & 1,8 & 2,5 & 2,4 & 1,9 & 2,6 & 1,4 & 2,1 & 2,3 & 1,8 \\
\hline Gas & 0,1 & 0,1 & 0,2 & 0,1 & 0,1 & 0,0 & 0,0 & 0,0 & 0,1 & 0,1 \\
\hline Liquid fuels & 0,1 & 0,9 & 0,4 & 0,4 & 0,3 & 0,4 & 0,2 & 0,2 & 0,4 & 0,3 \\
\hline Solid fuels & 0,1 & 0,5 & 0,4 & 0,3 & 0,5 & 0,1 & 0,1 & 0,5 & 1,0 & 0,3 \\
\hline $\begin{array}{l}\text { Furnishings, household equipment and routine } \\
\text { maintenance of the dwelling }\end{array}$ & 5,2 & 7,3 & 8,6 & 8,3 & 7,2 & 8,2 & 6,4 & 9,2 & 8,8 & 6,9 \\
\hline Furniture and furnishings & 0,9 & 1,4 & 1,7 & 1,6 & 1,2 & 1,5 & 1,1 & 1,9 & 2,0 & 1,3 \\
\hline Carpets and other floor covering & 0,2 & 0,2 & 0,1 & 0,2 & 0,2 & 0,1 & 0,1 & 0,2 & 0,1 & 0,2 \\
\hline Repair of furniture, furnishings and floor covering & 0,0 & 0,0 & 0,0 & 0,0 & 0,1 & 0,0 & 0,0 & 0,1 & 0,0 & 0,0 \\
\hline Household textiles & 0,8 & 1,7 & 2,0 & 1,7 & 1,3 & 1,6 & 1,0 & 2,2 & 2,1 & 1,3 \\
\hline Major household appliances & 0,6 & 0,9 & 1,6 & 1,0 & 0,9 & 0,9 & 0,6 & 1,2 & 1,3 & 0,8 \\
\hline Small electrical household appliances & 0,1 & 0,1 & 0,1 & 0,1 & 0,2 & 0,2 & 0,1 & 0,2 & 0,1 & 0,1 \\
\hline
\end{tabular}




\begin{tabular}{|c|c|c|c|c|c|c|c|c|c|c|}
\hline & $\begin{array}{r}\text { Western } \\
\text { Cape }\end{array}$ & $\begin{array}{r}\text { Eastern } \\
\text { Cape }\end{array}$ & $\begin{array}{r}\text { Northern } \\
\text { Cape }\end{array}$ & \begin{tabular}{r|} 
Free \\
State
\end{tabular} & $\begin{array}{r}\text { KwaZulu- } \\
\text { Natal }\end{array}$ & $\begin{array}{l}\text { North } \\
\text { West }\end{array}$ & Gauteng & Mpumalanga & Limpopo & Total \\
\hline Repair of household appliances & 0,0 & 0,0 & 0,0 & 0,0 & 0,0 & 0,0 & 0,0 & 0,0 & 0,1 & 0,0 \\
\hline Glassware, tableware and household utensils & 0,1 & 0,3 & 0,2 & 0,3 & 0,2 & 0,2 & 0,2 & 0,3 & 0,3 & 0,2 \\
\hline Major tools and equipment & 0,0 & 0,0 & 0,1 & 0,0 & 0,0 & 0,0 & 0,0 & 0,0 & 0,0 & 0,0 \\
\hline Small tools and miscellaneous accessories & 0,1 & 0,1 & 0,1 & 0,1 & 0,1 & 0,1 & 0,1 & 0,1 & 0,1 & 0,1 \\
\hline Non-durable household goods & 0,6 & 0,9 & 1,1 & 0,9 & 0,8 & 0,9 & 0,8 & 1,1 & 1,3 & 0,8 \\
\hline Domestic services and household arcticles & 1,9 & 1,6 & 1,7 & 2,3 & 2,2 & 2,7 & 2,3 & 1,9 & 1,3 & 2,1 \\
\hline Health & 1,4 & 1,6 & 1,6 & 2,3 & 1,7 & 1,7 & 1,8 & 1,4 & 1,4 & 1,7 \\
\hline Medical products, appliances and equipment & 0,6 & 0,7 & 0,6 & 1,0 & 0,6 & 0,7 & 0,6 & 0,5 & 0,5 & 0,6 \\
\hline Out-patient services & 0,7 & 0,8 & 0,7 & 0,9 & 0,9 & 0,8 & 1,0 & 0,8 & 0,8 & 0,9 \\
\hline Hospital services & 0,1 & 0,1 & 0,4 & 0,4 & 0,2 & 0,1 & 0,3 & 0,1 & 0,1 & 0,2 \\
\hline Transport & 21,5 & 19,1 & 19,0 & 21,4 & 18,4 & 17,8 & 20,6 & 21,7 & 14,5 & 19,9 \\
\hline Motor cars & 14,6 & 10,6 & 11,3 & 12,8 & 9,1 & 8,3 & 11,4 & 14,2 & 5,9 & 11,4 \\
\hline Motorcycles & 0,1 & & 0,1 & 0,0 & 0,0 & 0,2 & 0,1 & - & - & 0,1 \\
\hline Bicycles & 0,1 & 0,0 & 0,0 & 0,0 & 0,0 & 0,0 & 0,0 & 0,0 & 0,0 & 0,0 \\
\hline Animal-drawn vehicles & 0,0 & 0,0 & 0,0 & 0,0 & 0,0 & 0,0 & 0,0 & 0,0 & 0,0 & 0,0 \\
\hline Spare parts and accessories & 0,6 & 0,5 & 0,9 & 0,8 & 0,6 & 0,8 & 0,5 & 0,5 & 0,7 & 0,6 \\
\hline Fuels and lubricants & 3,4 & 3,3 & 3,5 & 3,7 & 3,4 & 3,8 & 3,8 & 2,5 & 2,9 & 3,5 \\
\hline Maintenance and repair of personal transport equipment & 0,6 & 0,3 & 0,4 & 0,5 & 0,5 & 0,4 & 0,5 & 0,3 & 0,3 & 0,5 \\
\hline Other services in respect of personal transport equipment & 0,5 & 0,3 & 0,4 & 0,5 & 0,5 & 0,6 & 0,6 & 0,5 & 0,6 & 0,5 \\
\hline Passenger transport by rail & 0,2 & 0,1 & 0,1 & 0,1 & 0,1 & 0,1 & 0,2 & 0,1 & 0,1 & 0,2 \\
\hline Passenger transport by road & 1,1 & 3,7 & 2,2 & 2,9 & 3,9 & 3,6 & 3,0 & 3,5 & 4,1 & 2,9 \\
\hline
\end{tabular}




\begin{tabular}{|c|c|c|c|c|c|c|c|c|c|c|}
\hline & \begin{tabular}{r|} 
Western \\
Cape
\end{tabular} & \begin{tabular}{r|} 
Eastern \\
Cape
\end{tabular} & $\begin{array}{r}\text { Northern } \\
\text { Cape }\end{array}$ & \begin{tabular}{r|} 
Free \\
State
\end{tabular} & $\begin{array}{r}\text { KwaZulu- } \\
\text { Natal }\end{array}$ & \begin{tabular}{r|r} 
North \\
West
\end{tabular} & Gauteng & Mpumalanga & Limpopo & Total \\
\hline Passenger transport by air & 0,3 & 0,2 & 0,1 & 0,1 & 0,2 & 0,1 & 0,5 & 0,0 & 0,1 & 0,3 \\
\hline Passenger transport by sea and inland waterway & 0,0 & 0,0 & - & 0,0 & 0,0 & - & 0,0 & 0,0 & - & 0,0 \\
\hline Other puchased transport services & 0,1 & 0,1 & 0,0 & 0,1 & 0,0 & 0,0 & 0,0 & 0,0 & 0,1 & 0,0 \\
\hline Cost for other modes of transport & 0,0 & 0,0 & 0,0 & 0,0 & 0,0 & 0,0 & 0,0 & 0,0 & 0,0 & 0,0 \\
\hline Communication & 3,7 & 3,3 & 3,6 & 3,6 & 4,0 & 3,7 & 3,3 & 3,4 & 3,1 & 3,5 \\
\hline Postal services & 0,0 & 0,1 & 0,1 & 0,1 & 0,1 & 0,1 & 0,1 & 0,1 & 0,1 & 0,1 \\
\hline Telephone and telefax equipment & 0,3 & 0,6 & 0,5 & 0,5 & 0,5 & 0,4 & 0,3 & 0,6 & 0,8 & 0,4 \\
\hline Telephone and telefax services & 3,4 & 2,7 & 3,0 & 3,0 & 3,4 & 3,2 & 2,9 & 2,6 & 2,3 & 3,0 \\
\hline Recreation and culture & 5,3 & 3,4 & 4,4 & 4,5 & 4,6 & 4,0 & 4,9 & 4,3 & 3,6 & 4,6 \\
\hline $\begin{array}{l}\text { Audio-visual, photographic and information processing } \\
\text { equipment }\end{array}$ & 1,5 & 1,3 & 1,9 & 1,7 & 1,5 & 1,5 & 1,3 & 1,9 & 1,8 & 1,5 \\
\hline Other major durables for recreation and culture & 0,1 & 0,0 & 0,2 & 0,1 & 0,0 & 0,1 & 0,1 & 0,3 & 0,1 & 0,1 \\
\hline Other recreational items and equipment, garden and pets & 1,3 & 0,5 & 0,6 & 0,7 & 0,7 & 0,7 & 0,9 & 0,5 & 0,4 & 0,8 \\
\hline Recreational and cultural services & 1,6 & 0,7 & 1,0 & 1,2 & 1,0 & 1,0 & 1,6 & 1,0 & 0,7 & 1,3 \\
\hline Newspapers, books and stationery & 0,8 & 0,7 & 0,6 & 0,7 & 0,8 & 0,7 & 0,9 & 0,6 & 0,6 & 0,8 \\
\hline Package holidays & 0,2 & 0,1 & 0,0 & 0,1 & 0,5 & 0,0 & 0,2 & 0,0 & 0,0 & 0,2 \\
\hline Education & 1,9 & 2,0 & 1,2 & 2,5 & 2,6 & 3,7 & 2,4 & 2,4 & 3,2 & 2,4 \\
\hline Pre-primary and primary education & 0,6 & 0,7 & 0,4 & 0,4 & 0,6 & 0,5 & 0,7 & 0,5 & 0,7 & 0,6 \\
\hline Secondary education & 0,5 & 0,5 & 0,3 & 0,5 & 0,7 & 0,6 & 0,7 & 1,2 & 0,8 & 0,6 \\
\hline Tertiary education & 0,8 & 0,6 & 0,4 & 1,0 & 1,2 & 2,5 & 0,7 & 0,6 & 1,6 & 0,9 \\
\hline Education not definable by level & 0,1 & 0,2 & 0,0 & 0,7 & 0,1 & 0,1 & 0,4 & 0,1 & 0,1 & 0,2 \\
\hline Restaurants and hotels & 2,3 & 1,8 & 2,7 & 2,5 & 1,6 & 1,9 & 2,4 & 1,7 & 3,0 & 2,2 \\
\hline Beverages in restaurants, cafes, canteens and the like & 0,2 & 0,6 & 0,7 & 0,5 & 0,3 & 0,4 & 0,4 & 0,5 & 0,4 & 0,4 \\
\hline Meals in restaurants, cafes, canteens and the like & 1,4 & 0,8 & 1,2 & 1,2 & 0,6 & 0,8 & 1,1 & 0,5 & 1,6 & 1,0 \\
\hline Accommodation services & 0,7 & 0,5 & 0,8 & 0,8 & 0,8 & 0,7 & 1,0 & 0,8 & 0,9 & 0,8 \\
\hline
\end{tabular}




\begin{tabular}{|c|c|c|c|c|c|c|c|c|c|c|}
\hline & $\begin{array}{r}\text { Western } \\
\text { Cape }\end{array}$ & $\begin{array}{r}\text { Eastern } \\
\text { Cape }\end{array}$ & $\begin{array}{r}\text { Northern } \\
\text { Cape }\end{array}$ & \begin{tabular}{r|} 
Free \\
State
\end{tabular} & $\begin{array}{r}\text { KwaZulu- } \\
\text { Natal }\end{array}$ & $\begin{array}{l}\text { North } \\
\text { West }\end{array}$ & Gauteng & Mpumalanga & Limpopo & Total \\
\hline Miscellaneous goods and services & 12,1 & 15,2 & 14,7 & 15,0 & 13,4 & 17,6 & 15,4 & 15,4 & 12,3 & 14,4 \\
\hline Hairdressing salons and personal grooming establishments & 0,1 & 0,1 & 0,0 & 0,1 & 0,0 & 0,1 & 0,1 & 0,1 & 0,1 & 0,1 \\
\hline Electrical appliances for personal care & 0,0 & 0,0 & 0,0 & 0,0 & 0,0 & 0,0 & 0,0 & 0,0 & 0,0 & 0,0 \\
\hline Other appliances, articles and products for personal care & 1,1 & 1,0 & 1,5 & 1,2 & 1,0 & 1,2 & 1,3 & 1,2 & 1,2 & 1,2 \\
\hline Jewellery, clocks and watches & 0,2 & 0,2 & 0,2 & 0,4 & 0,4 & 0,2 & 0,2 & 0,2 & 0,3 & 0,3 \\
\hline Other personal effects & 0,2 & 0,2 & 0,2 & 0,2 & 0,2 & 0,2 & 0,2 & 0,2 & 0,2 & 0,2 \\
\hline Social protection services & 0,2 & 0,2 & 0,1 & 0,2 & 0,1 & 0,2 & 0,3 & 0,2 & 0,1 & 0,2 \\
\hline Insurance connected with the dwelling & 2,2 & 1,4 & 1,7 & 1,8 & 1,7 & 2,9 & 4,4 & 2,3 & 1,4 & 2,8 \\
\hline Insurance connected with health & 3,3 & 3,5 & 3,2 & 4,0 & 2,6 & 5,1 & 3,5 & 4,4 & 2,1 & 3,4 \\
\hline Insurance connected with transport & 0,9 & 0,7 & 0,7 & 0,8 & 1,0 & 0,4 & 1,0 & 0,7 & 0,4 & 0,8 \\
\hline Other insurance & 0,6 & 2,0 & 2,3 & 1,8 & 1,2 & 1,2 & 0,8 & 1,2 & 1,5 & 1,1 \\
\hline Financial services n.e.c. & 1,0 & 1,7 & 1,5 & 1,2 & 1,3 & 3,3 & 1,2 & 2,0 & 1,2 & 1,4 \\
\hline Other services & 2,2 & 4,2 & 3,4 & 3,4 & 3,9 & 3,0 & 2,4 & 3,1 & 3,9 & 3,0 \\
\hline Other unclassified expenses & 0,6 & 0,2 & 0,1 & 0,1 & 0,4 & 0,1 & 0,2 & 0,1 & 0,5 & 0,3 \\
\hline Total & 100,0 & 100,0 & 100,0 & 100,0 & 100,0 & 100,0 & 100,0 & 100,0 & 100,0 & 100,0 \\
\hline
\end{tabular}

Due to rounding, figures do not necessarily add up to totals

- No expenditure 


\section{Expenditure}

Table 2.19 - Average household consumption expenditure by main expenditure group and population group of household head

\begin{tabular}{|c|c|c|c|c|c|c|}
\hline & Black African & Coloured & Indian/Asian & White & Unspecified & Total \\
\hline Number of households in sample & 16110 & 2691 & 348 & 1974 & 21 & 21144 \\
\hline Number of households in population & 9566382 & 965778 & 310652 & 1596888 & 17881 & 12457581 \\
\hline Average household size & 4,2 & 4,3 & 3,9 & 2,7 & 2,9 & 3,8 \\
\hline Main expenditure group & \multicolumn{6}{|c|}{ Rand per household per year } \\
\hline Food and non-alcoholic beverages & 6542 & 10912 & 10129 & 15361 & 9838 & 8105 \\
\hline Alcoholic beverages and tobacco & 413 & 1374 & 822 & 1574 & 915 & 647 \\
\hline Clothing and footwear & 2248 & 3496 & 4563 & 5193 & 2476 & 2781 \\
\hline Housing, water, electricity, gas and other fuels & 5456 & 14161 & 27937 & 56422 & 19910 & 13245 \\
\hline $\begin{array}{l}\text { Furnishings, household equipment and routine maintenance of the } \\
\text { dwelling }\end{array}$ & 2469 & 3190 & 6142 & 12212 & 4056 & 3868 \\
\hline Health & 452 & 718 & 1606 & 3814 & 798 & 933 \\
\hline Transport & 5341 & 10428 & 25592 & 43849 & 7682 & 11180 \\
\hline Communication & 1012 & 2233 & 4082 & 7115 & 3657 & 1969 \\
\hline Recreation and culture & 1081 & 2767 & 5540 & 10878 & 3067 & 2582 \\
\hline Education & 830 & 1101 & 2265 & 4485 & 1378 & 1356 \\
\hline Restaurants and hotels & 692 & 1088 & 2065 & 4402 & 807 & 1232 \\
\hline Miscellaneous goods and services & 3898 & 7039 & 13492 & 32674 & 12372 & 8081 \\
\hline Other unclassified expenses & 75 & 297 & 299 & 655 & 321 & 172 \\
\hline Total & 30509 & 58805 & 104533 & 198632 & 67278 & 56152 \\
\hline
\end{tabular}

Due to rounding, figures do not necessarily add up to totals 


\section{Expenditure}

Table 2.20 - Average household consumption expenditure by secondary expenditure group and population group of household head

\begin{tabular}{|c|c|c|c|c|c|c|}
\hline & Black African & Coloured & Indian/Asian & White & Unspecified & Total \\
\hline Number of households in sample & 16110 & 2691 & 348 & 1974 & 21 & 21144 \\
\hline Number of households in population & 9566382 & 965778 & 310652 & 1596888 & 17881 & 12457581 \\
\hline Average household size & 4,2 & 4,3 & 3,9 & 2,7 & 2,9 & 3,8 \\
\hline Secondary expenditure group & \multicolumn{6}{|c|}{ Rand per household per year } \\
\hline Food and non-alcoholic beverages & 6542 & 10912 & 10129 & 15361 & 9838 & 8105 \\
\hline Food & 5803 & 8934 & 8119 & 11376 & 7405 & 6820 \\
\hline Non-alcoholic beverages & 441 & 789 & 815 & 1366 & 1150 & 597 \\
\hline Unspecified food & 298 & 1189 & 1195 & 2619 & 1283 & 688 \\
\hline Alcoholic beverages and tobacco & 413 & 1374 & 822 & 1574 & 915 & 647 \\
\hline Alcoholic beverages & 195 & 337 & 165 & 702 & 559 & 271 \\
\hline Tobacco & 218 & 1037 & 656 & 872 & 356 & 377 \\
\hline Clothing and footwear & 2248 & 3496 & 4563 & 5193 & 2476 & 2781 \\
\hline Clothing & 1574 & 2465 & 3328 & 3746 & 1558 & 1966 \\
\hline Footwear & 674 & 1031 & 1235 & 1446 & 917 & 815 \\
\hline Housing, water, electricity, gas and other fuels & 5456 & 14161 & 27937 & 56422 & 19910 & 13245 \\
\hline Actual rentals for housing & 1014 & 2259 & 4472 & 7318 & 9682 & 2017 \\
\hline Imputed rentals for housing & 2272 & 7080 & 14243 & 34525 & 4907 & 7081 \\
\hline Maintenance and repair of the dwelling & 367 & 989 & 769 & 4673 & 757 & 978 \\
\hline Water supply and miscellaneous services relating to the dwelling & 732 & 2187 & 6944 & 6927 & 3185 & 1798 \\
\hline Electricity, gas and other fuels & 1071 & 1645 & 1507 & 2979 & 1379 & 1371 \\
\hline
\end{tabular}




\begin{tabular}{|c|c|c|c|c|c|c|}
\hline & Black African & Coloured & Indian/Asian & White & Unspecified & Total \\
\hline $\begin{array}{l}\text { Furnishings, household equipment and routine maintenance of the } \\
\text { dwelling }\end{array}$ & 2469 & 3190 & 6142 & 12212 & 4056 & 3868 \\
\hline Furniture and furnishings, carpets and other floor covering & 666 & 608 & 641 & 1869 & 188 & 814 \\
\hline Household textiles & 651 & 654 & 933 & 1073 & 511 & 712 \\
\hline Household appliances & 437 & 658 & 956 & 1084 & 339 & 550 \\
\hline Glassware, tableware and household utensils & 93 & 89 & 153 & 202 & 101 & 108 \\
\hline Tools and equipment for house and garden & 34 & 58 & 51 & 277 & 43 & 67 \\
\hline Goods and services for routine household maintenance & 589 & 1123 & 3408 & 7707 & 2874 & 1617 \\
\hline Health & 452 & 718 & 1606 & 3814 & 798 & 933 \\
\hline Medical products, appliances and equipment & 155 & 308 & 662 & 1488 & 398 & 351 \\
\hline Out-patient services & 257 & 315 & 791 & 1833 & 399 & 477 \\
\hline Hospital services & 40 & 95 & 152 & 493 & 1 & 105 \\
\hline Transport & 5341 & 10428 & 25592 & 43849 & 7682 & 11180 \\
\hline Purchase of vehicles & 2244 & 5909 & 16355 & 30032 & & 6439 \\
\hline Operation of personal transport equipment & 1123 & 2814 & 7466 & 12127 & 5449 & 2829 \\
\hline Transport services & 1973 & 1704 & 1739 & 1673 & 2234 & 1908 \\
\hline Operational values of other modes of transport & 1 & 1 & 31 & 17 & & 4 \\
\hline Communication & 1012 & 2233 & 4082 & 7115 & 3657 & 1969 \\
\hline Postal services & 14 & 19 & 124 & 136 & 40 & 33 \\
\hline Telephone and telefax equipment & 226 & 234 & 278 & 280 & 284 & 235 \\
\hline Telephone and telefax services & 773 & 1980 & 3681 & 6699 & 3333 & 1702 \\
\hline Recreation and culture & 1081 & 2767 & 5540 & 10878 & 3067 & 2582 \\
\hline Audio-visual, photographic and information processing equipment & 507 & 933 & 1901 & 2491 & 1093 & 830 \\
\hline Other major durables for recreation and culture & 19 & 14 & 15 & 229 & 32 & 45 \\
\hline Other recreational items and equipment, garden and pets & 58 & 584 & 945 & 2675 & 591 & 457 \\
\hline Recreational and cultural services & 243 & 691 & 1111 & 3444 & 809 & 711 \\
\hline Newspapers, books and stationery & 241 & 494 & 734 & 1470 & 542 & 431 \\
\hline Package holidays & 13 & 51 & 835 & 569 & & 107 \\
\hline
\end{tabular}




\begin{tabular}{|c|c|c|c|c|c|c|}
\hline & Black African & Coloured & Indian/Asian & White & Unspecified & Total \\
\hline Education & 830 & 1101 & 2265 & 4485 & 1378 & 1356 \\
\hline Pre-primary and primary education & 187 & 501 & 548 & 1129 & 148 & 341 \\
\hline Secondary education & 189 & 274 & 550 & 1389 & 613 & 359 \\
\hline Tertiary education & 311 & 307 & 1159 & 1777 & 603 & 520 \\
\hline Education not definable by level & 143 & 20 & 9 & 190 & 14 & 136 \\
\hline Restaurants and hotels & 692 & 1088 & 2065 & 4402 & 807 & 1232 \\
\hline Catering services & 543 & 754 & 1054 & 2115 & 489 & 773 \\
\hline Accommodation services & 149 & 334 & 1011 & 2287 & 318 & 459 \\
\hline Miscellaneous goods and services & 3898 & 7039 & 13492 & 32674 & 12372 & 8081 \\
\hline Personal care & 462 & 832 & 955 & 1961 & 863 & 696 \\
\hline Personal effects & 137 & 263 & 638 & 886 & 94 & 255 \\
\hline Social protection & 78 & 202 & 161 & 324 & & 121 \\
\hline Insurance & 1532 & 3493 & 8392 & 22392 & 8804 & 4540 \\
\hline Financial services n.e.c. & 434 & 898 & 1262 & 2765 & 680 & 790 \\
\hline Other services n.e.c. & 1254 & 1352 & 2084 & 4345 & 1930 & 1680 \\
\hline Other unclassified expenses & 75 & 297 & 299 & 655 & 321 & 172 \\
\hline Total & 30509 & 58805 & 104533 & 198632 & 67278 & 56152 \\
\hline
\end{tabular}




\section{Expenditure}

Table 2.21 - Average household consumption expenditure by third expenditure group and population group of household head

\begin{tabular}{|c|c|c|c|c|c|c|}
\hline & Black African & Coloured & Indian/Asian & White & Unspecified & Total \\
\hline Number of households in sample & 16110 & 2691 & 348 & 1974 & 21 & 21144 \\
\hline Number of households in population & 9566382 & 965778 & 310652 & 1596888 & 17881 & 12457581 \\
\hline Average household size & 4,2 & 4,3 & 3,9 & 2,7 & 2,9 & 3,8 \\
\hline Third expenditure group & \multicolumn{6}{|c|}{ Rand per household per year } \\
\hline Food and non-alcoholic beverages & 6542 & 10912 & 10129 & 15361 & 9838 & 8105 \\
\hline Bread and cereals & 1683 & 1704 & 1783 & 1692 & 1595 & 1688 \\
\hline Meat & 1650 & 3284 & 2249 & 3588 & 1517 & 2039 \\
\hline Fish & 217 & 416 & 437 & 568 & 258 & 283 \\
\hline Milk, cheese and eggs & 572 & 1056 & 1089 & 1770 & 1195 & 777 \\
\hline Oils and fats & 239 & 308 & 314 & 370 & 279 & 263 \\
\hline Fruits & 133 & 180 & 241 & 657 & 427 & 207 \\
\hline Vegetables & 649 & 927 & 917 & 1374 & 1074 & 771 \\
\hline Sugar, jam, honey, chocolate and confectionery & 331 & 607 & 421 & 732 & 564 & 406 \\
\hline Food products n.e.c. & 329 & 452 & 667 & 627 & 495 & 386 \\
\hline Coffee, tea and cocoa & 105 & 250 & 154 & 344 & 273 & 148 \\
\hline Mineral waters, soft drinks, fruit and vegetable juices & 336 & 540 & 661 & 1022 & 877 & 449 \\
\hline Unspecified food & 298 & 1189 & 1195 & 2619 & 1283 & 688 \\
\hline Alcoholic beverages and tobacco & 413 & 1374 & 822 & 1574 & 915 & 647 \\
\hline Spirits & 41 & 128 & 36 & 231 & 239 & 72 \\
\hline Wine & 16 & 81 & 36 & 267 & 37 & 54 \\
\hline Beer & 138 & 128 & 93 & 204 & 284 & 145 \\
\hline Tobacco & 218 & 1037 & 656 & 872 & 356 & 377 \\
\hline
\end{tabular}




\begin{tabular}{|c|c|c|c|c|c|c|}
\hline & Black African & Coloured & Indian/Asian & White & Unspecified & Total \\
\hline Clothing and footwear & 2248 & 3496 & 4563 & 5193 & 2476 & 2781 \\
\hline Clothing materials & 15 & 10 & 64 & 45 & & 20 \\
\hline Garments & 1518 & 2420 & 3179 & 3549 & 1493 & 1889 \\
\hline Other articles of clothing and clothing accessories & 33 & 30 & 83 & 128 & 65 & 46 \\
\hline Cleaning, repair and hire of clothing & 9 & 4 & 3 & 25 & - & 10 \\
\hline Shoes and other footwear & 667 & 1029 & 1230 & 1443 & 917 & 809 \\
\hline Repair and hire of foowear & 7 & & 5 & & - & 6 \\
\hline Housing, water, electricity, gas and other fuels & 5456 & 14161 & 27937 & 56422 & 19910 & 13245 \\
\hline Actual rentals paid by tenants & 1014 & 2259 & 4472 & 7318 & 9682 & 2017 \\
\hline Imputed rentals of owner-occupiers & 2272 & 7080 & 14243 & 34525 & 4907 & 7081 \\
\hline Materials for maintenance and repair of the dwelling & 186 & 224 & 354 & 1568 & 20 & 370 \\
\hline Service of the maintenance and repair of the dwelling & 181 & 764 & 416 & 3105 & 736 & 608 \\
\hline Water and electricity & 173 & 449 & 3957 & 2048 & 839 & 530 \\
\hline Water supply & 213 & 474 & 703 & 1072 & 223 & 356 \\
\hline Refuse collection & 69 & 203 & 165 & 291 & 371 & 110 \\
\hline Sewerage collection & 77 & 208 & 165 & 363 & 240 & 126 \\
\hline Other services relating to the dwelling & 200 & 854 & 1954 & 3153 & 1513 & 675 \\
\hline Electricity & 663 & 1510 & 1415 & 2819 & 1274 & 1024 \\
\hline Gas & 28 & 31 & 36 & 84 & - & 36 \\
\hline Liquid fuels & 204 & 56 & 16 & 24 & 84 & 165 \\
\hline Solid fuels & 176 & 48 & 40 & 52 & 21 & 147 \\
\hline $\begin{array}{l}\text { Furnishings, household equipment and routine maintenance of the } \\
\text { dwelling }\end{array}$ & 2469 & 3190 & 6142 & 12212 & 4056 & 3868 \\
\hline Furniture and furnishings & 605 & 459 & 548 & 1516 & 142 & 709 \\
\hline Carpets and other floor covering & 51 & 121 & 84 & 261 & 46 & 84 \\
\hline Repair of furniture, furnishings and floor covering & 10 & 28 & 8 & 92 & - & 22 \\
\hline Household textiles & 651 & 654 & 933 & 1073 & 511 & 712 \\
\hline Major household appliances & 371 & 543 & 768 & 845 & 237 & 455 \\
\hline Small electrical household appliances & 56 & 103 & 159 & 163 & 95 & 76 \\
\hline
\end{tabular}




\begin{tabular}{|c|c|c|c|c|c|c|}
\hline & Black African & Coloured & Indian/Asian & White & Unspecified & Total \\
\hline Repair of household appliances & 10 & 12 & 29 & 75 & 6 & 19 \\
\hline Glassware, tableware and household utensils & 93 & 89 & 153 & 202 & 101 & 108 \\
\hline Major tools and equipment & 6 & 23 & 15 & 111 & 18 & 21 \\
\hline Small tools and miscellaneous accessories & 27 & 35 & 36 & 166 & 26 & 46 \\
\hline Non-durable household goods & 379 & 480 & 453 & 958 & 496 & 463 \\
\hline Domestic services and household arcticles & 210 & 644 & 2955 & 6749 & 2378 & 1154 \\
\hline Health & 452 & 718 & 1606 & 3814 & 798 & 933 \\
\hline Pharmaceutical products & 141 & 269 & 577 & 1320 & 354 & 314 \\
\hline Other medical products & 6 & 13 & 24 & 36 & 2 & 11 \\
\hline Therapeutic appliances and equipment & 7 & 25 & 61 & 132 & 42 & 26 \\
\hline Medical services & 232 & 251 & 393 & 1202 & 359 & 362 \\
\hline Dental services & 11 & 21 & 85 & 328 & 14 & 54 \\
\hline Paramedic services & 15 & 43 & 313 & 302 & 26 & 62 \\
\hline Hospital services & 40 & 95 & 152 & 493 & 1 & 105 \\
\hline Transport & 5341 & 10428 & 25592 & 43849 & 7682 & 11180 \\
\hline Motor cars & 2236 & 5841 & 16355 & 29683 & & 6383 \\
\hline Motorcycles & 4 & 20 & & 256 & - & 37 \\
\hline Bicycles & 2 & 47 & & 55 & - & 12 \\
\hline Animal-drawn vehicles & 2 & 2 & & 38 & - & 6 \\
\hline Spare parts and accessories & 152 & 361 & 700 & 1373 & 510 & 339 \\
\hline Fuels and lubricants & 717 & 1973 & 5551 & 8511 & 3915 & 1939 \\
\hline Maintenance and repair of personal transport equipment & 101 & 227 & 581 & 1171 & 366 & 260 \\
\hline Other services in respect of personal transport equipment & 153 & 253 & 635 & 1072 & 658 & 291 \\
\hline Passenger transport by rail & 94 & 89 & 28 & 31 & 14 & 84 \\
\hline Passenger transport by road & 1843 & 1579 & 1358 & 569 & 579 & 1646 \\
\hline
\end{tabular}




\begin{tabular}{|c|c|c|c|c|c|c|}
\hline & Black African & Coloured & Indian/Asian & White & Unspecified & Total \\
\hline Passenger transport by air & 23 & 26 & 349 & 1001 & 1641 & 159 \\
\hline Passenger transport by sea and inland waterway & - & - & - & 9 & & 1 \\
\hline Other puchased transport services & 12 & 11 & 4 & 63 & - & 19 \\
\hline Cost for other modes of transport & 1 & 1 & 31 & 17 & - & 4 \\
\hline Communication & 1012 & 2233 & 4082 & 7115 & 3657 & 1969 \\
\hline Postal services & 14 & 19 & 124 & 136 & 40 & 33 \\
\hline Telephone and telefax equipment & 226 & 234 & 278 & 280 & 284 & 235 \\
\hline Telephone and telefax services & 773 & 1980 & 3681 & 6699 & 3333 & 1702 \\
\hline Recreation and culture & 1081 & 2767 & 5540 & 10878 & 3067 & 2582 \\
\hline $\begin{array}{l}\text { Equipment for the reception, recording and reproduction of sound and } \\
\text { pictures }\end{array}$ & 364 & 588 & 471 & 645 & 677 & 420 \\
\hline Photographic and cinematographic equipment and optical instruments & 10 & 46 & 155 & 356 & 115 & 61 \\
\hline Information processing equipment & 73 & 202 & 941 & 1107 & 124 & 237 \\
\hline Recording media & 61 & 97 & 335 & 383 & 177 & 112 \\
\hline Major durables for outdoor recreation & 1 & 3 & - & 135 & - & 19 \\
\hline Musical instruments and major durables for outdoor recreation & 10 & 5 & 2 & 68 & - & 17 \\
\hline Maintenance and repair of other major durables for recreation and culture & 8 & 6 & 12 & 26 & 32 & 10 \\
\hline Games, toys and hobbies & 10 & 87 & 247 & 372 & 120 & 68 \\
\hline Equipment for sport, camping and open-air recreation & 13 & 190 & 86 & 434 & - & 82 \\
\hline Gardens, plants and flowers & 8 & 61 & 110 & 593 & 81 & 90 \\
\hline Pets and related products & 26 & 225 & 311 & 998 & 364 & 174 \\
\hline Veterinary and other services & 1 & 21 & 191 & 277 & 26 & 43 \\
\hline Recreational and sporting services & 42 & 91 & 148 & 899 & 89 & 158 \\
\hline Cultural services & 82 & 404 & 747 & 1789 & 606 & 343 \\
\hline Games of chance & 120 & 196 & 216 & 755 & 115 & 209 \\
\hline Books & 51 & 118 & 251 & 416 & 113 & 108 \\
\hline Newspaper and periodicals & 131 & 250 & 324 & 783 & 360 & 229 \\
\hline Miscellaneous printed matter & 2 & 9 & 8 & 47 & 8 & 8 \\
\hline Stationery and drawing materials & 57 & 118 & 151 & 225 & 61 & 85 \\
\hline Package holidays & 13 & 51 & 835 & 569 & - & 107 \\
\hline
\end{tabular}




\begin{tabular}{|c|c|c|c|c|c|c|}
\hline & Black African & Coloured & Indian/Asian & White & Unspecified & Total \\
\hline Education & 830 & 1101 & 2265 & 4485 & 1378 & 1356 \\
\hline Pre-primary and primary education & 187 & 501 & 548 & 1129 & 148 & 341 \\
\hline Secondary education & 189 & 274 & 550 & 1389 & 613 & 359 \\
\hline Tertiary education & 311 & 307 & 1159 & 1777 & 603 & 520 \\
\hline Education not definable by level & 143 & 20 & 9 & 190 & 14 & 136 \\
\hline Restaurants and hotels & 692 & 1088 & 2065 & 4402 & 807 & 1232 \\
\hline Beverages in restaurants, cafes, canteens and the like & 201 & 176 & 34 & 263 & 75 & 203 \\
\hline Meals in restaurants, cafes, canteens and the like & 342 & 578 & 1020 & 1852 & 413 & 571 \\
\hline Accommodation services & 149 & 334 & 1011 & 2287 & 318 & 459 \\
\hline Miscellaneous goods and services & 3898 & 7039 & 13492 & 32674 & 12372 & 8081 \\
\hline Hairdressing salons and personal grooming establishments & 14 & 38 & 61 & 211 & 11 & 42 \\
\hline Electrical appliances for personal care & 3 & 5 & 4 & 24 & - & 6 \\
\hline Other appliances, articles and products for personal care & 445 & 789 & 890 & 1727 & 852 & 648 \\
\hline Jewellery, clocks and watches & 62 & 163 & 445 & 524 & 25 & 139 \\
\hline Other personal effects & 74 & 99 & 193 & 362 & 70 & 116 \\
\hline Social protection services & 78 & 202 & 161 & 324 & - & 121 \\
\hline Insurance connected with the dwelling & 187 & 788 & 3363 & 9794 & 2093 & 1547 \\
\hline Insurance connected with health & 637 & 1762 & 3298 & 9350 & 5055 & 1914 \\
\hline Insurance connected with transport & 105 & 286 & 1251 & 2601 & 1409 & 469 \\
\hline Other insurance & 604 & 658 & 480 & 647 & 247 & 610 \\
\hline Financial services n.e.c. & 434 & 898 & 1262 & 2765 & 680 & 790 \\
\hline Other services & 1254 & 1352 & 2084 & 4345 & 1930 & 1680 \\
\hline Other unclassified expenses & 75 & 297 & 299 & 655 & 321 & 172 \\
\hline Total & 30509 & 58805 & 104533 & 198632 & 67278 & 56152 \\
\hline
\end{tabular}

Due to rounding, figures do not necessarily add up to totals

- No expenditure 


\section{Expenditure}

Table 2.22 Average household consumption expenditure by main expenditure group and sex of household head

\begin{tabular}{|c|c|c|c|}
\hline & Male & Female & *Total \\
\hline Number of households in sample & 11815 & 9310 & 21144 \\
\hline Number of households in population & 7607409 & 4841472 & 12457580 \\
\hline Average of household size & 3,8 & 4,3 & 3,8 \\
\hline Main expenditure group & \multicolumn{3}{|c|}{ Rand per household per year } \\
\hline Food and non-alcoholic beverages & 8578 & 7364 & 8105 \\
\hline Alcoholic beverages and tobacco & 842 & 340 & 647 \\
\hline Clothing and footwear & 3026 & 2396 & 2781 \\
\hline Housing, water, electricity, gas and other fuels & 16035 & 8868 & 13245 \\
\hline $\begin{array}{l}\text { Furnishings, household equipment and routine maintenance of the } \\
\text { dwelling }\end{array}$ & 4450 & 2949 & 3868 \\
\hline Health & 1135 & 615 & 933 \\
\hline Transport & 14272 & 6333 & 11180 \\
\hline Communication & 2382 & 1322 & 1969 \\
\hline Recreation and culture & 3270 & 1501 & 2582 \\
\hline Education & 1588 & 993 & 1356 \\
\hline Restaurants and hotels & 1579 & 688 & 1232 \\
\hline Miscellaneous goods and services & 9768 & 5436 & 8081 \\
\hline Other unclassified expenses & 205 & 121 & 172 \\
\hline Total & 67128 & 38927 & 56152 \\
\hline
\end{tabular}

*Total includes households with unspecified sex of household head

Due to rounding, figures do not necessarily add up to totals 


\section{Expenditure}

Table 2.23 - Average household consumption expenditure by secondary expenditure group and sex of household head

\begin{tabular}{|c|c|c|c|}
\hline & Male & Female & *Total \\
\hline Number of households in sample & 11815 & 9310 & 21144 \\
\hline Number of households in population & 7607409 & 4841472 & 12457580 \\
\hline Average of household size & 3,8 & 4,3 & 3,8 \\
\hline Secondary expenditure group & \multicolumn{3}{|c|}{ Rand per household per year } \\
\hline Food and non-alcoholic beverages & 8578 & 7364 & 8105 \\
\hline Food & 7083 & 6408 & 6820 \\
\hline Non-alcoholic beverages & 677 & 472 & 597 \\
\hline Unspecified food & 819 & 484 & 688 \\
\hline Alcoholic beverages and tobacco & 842 & 340 & 647 \\
\hline Alcoholic beverages & 362 & 126 & 271 \\
\hline Tobacco & 480 & 215 & 377 \\
\hline Clothing and footwear & 3026 & 2396 & 2781 \\
\hline Clothing & 2142 & 1689 & 1966 \\
\hline Footwear & 884 & 707 & 815 \\
\hline Housing, water, electricity, gas and other fuels & 16035 & 8868 & 13245 \\
\hline Actual rentals for housing & 2424 & 1381 & 2017 \\
\hline Imputed rentals for housing & 8770 & 4430 & 7081 \\
\hline Maintenance and repair of the dwelling & 1274 & 513 & 978 \\
\hline Water supply and miscellaneous services relating to the dwelling & 2116 & 1296 & 1798 \\
\hline Electricity, gas and other fuels & 1451 & 1248 & 1371 \\
\hline $\begin{array}{l}\text { Furnishings, household equipment and routine maintenance of the } \\
\text { dwelling }\end{array}$ & 4450 & 2949 & 3868 \\
\hline
\end{tabular}




\begin{tabular}{|c|c|c|c|}
\hline & Male & Female & *Total \\
\hline Furniture and furnishings, carpets and other floor covering & 895 & 687 & 814 \\
\hline Household textiles & 734 & 675 & 712 \\
\hline Household appliances & 611 & 453 & 550 \\
\hline Glassware, tableware and household utensils & 115 & 96 & 108 \\
\hline Tools and equipment for house and garden & 82 & 43 & 67 \\
\hline Goods and services for routine household maintenance & 2011 & 994 & 1617 \\
\hline Health & 1135 & 615 & 933 \\
\hline Medical products, appliances and equipment & 423 & 237 & 351 \\
\hline Out-patient services & 573 & 327 & 477 \\
\hline Hospital services & 139 & 51 & 105 \\
\hline Transport & 14272 & 6333 & 11180 \\
\hline Purchase of vehicles & 8464 & 3266 & 6439 \\
\hline Operation of personal transport equipment & 3783 & 1329 & 2829 \\
\hline Transport services & 2018 & 1738 & 1908 \\
\hline Operational values of other modes of transport & 6 & 1 & 4 \\
\hline Communication & 2382 & 1322 & 1969 \\
\hline Postal services & 43 & 17 & 33 \\
\hline Telephone and telefax equipment & 249 & 213 & 235 \\
\hline Telephone and telefax services & 2090 & 1093 & 1702 \\
\hline Recreation and culture & 3270 & 1501 & 2582 \\
\hline Audio-visual, photographic and information processing equipment & 1006 & 554 & 830 \\
\hline Other major durables for recreation and culture & 62 & 19 & 45 \\
\hline Other recreational items and equipment, garden and pets & 594 & 243 & 457 \\
\hline Recreational and cultural services & 935 & 360 & 711 \\
\hline
\end{tabular}




\begin{tabular}{|c|c|c|c|}
\hline & Male & Female & *Total \\
\hline Newspapers, books and stationery & 520 & 291 & 431 \\
\hline Package holidays & 154 & 35 & 107 \\
\hline Education & 1588 & 993 & 1356 \\
\hline Pre-primary and primary education & 417 & 221 & 341 \\
\hline Secondary education & 424 & 258 & 359 \\
\hline Tertiary education & 635 & 341 & 520 \\
\hline Education not definable by level & 112 & 174 & 136 \\
\hline Restaurants and hotels & 1579 & 688 & 1232 \\
\hline Catering services & 971 & 463 & 773 \\
\hline Accommodation services & 608 & 225 & 459 \\
\hline Miscellaneous goods and services & 9768 & 5436 & 8081 \\
\hline Personal care & 752 & 607 & 696 \\
\hline Personal effects & 300 & 184 & 255 \\
\hline Social protection & 144 & 87 & 121 \\
\hline Insurance & 5744 & 2651 & 4540 \\
\hline Financial services n.e.c. & 981 & 491 & 790 \\
\hline Other services n.e.c. & 1847 & 1416 & 1680 \\
\hline Other unclassified expenses & 205 & 121 & 172 \\
\hline Total & 67128 & 38927 & 56152 \\
\hline
\end{tabular}

*Total includes households with unspecified sex of household head

Due to rounding, figures do not necessarily add up to totals 


\section{Expenditure}

Table 2.24 - Average household consumption expenditure by third expenditure group and sex of household head

\begin{tabular}{|c|c|c|c|}
\hline & Male & Female & *Total \\
\hline Number of households in sample & 11815 & 9310 & 21144 \\
\hline Number ofouseholds in population & 7607409 & 4841472 & 12457580 \\
\hline Average household size & 3,8 & 4,3 & 3,8 \\
\hline Third expenditure group & \multicolumn{2}{|c|}{ Rand per household per year } & \\
\hline Food and non-alcoholic beverages & 8578 & 7364 & 8105 \\
\hline Bread and cereals & 1614 & 1807 & 1688 \\
\hline Meat & 2219 & 1758 & 2039 \\
\hline Fish & 342 & 192 & 283 \\
\hline Milk, cheese and eggs & 850 & 662 & 777 \\
\hline Oils and fats & 260 & 267 & 263 \\
\hline Fruits & 228 & 174 & 207 \\
\hline Vegetables & 770 & 772 & 771 \\
\hline Sugar, jam, honey, chocolate and confectionery & 404 & 408 & 406 \\
\hline Food products n.e.c. & 397 & 368 & 386 \\
\hline Coffee, tea and cocoa & 160 & 130 & 148 \\
\hline Mineral waters, soft drinks, fruit and vegetable juices & 517 & 342 & 449 \\
\hline Unspecified food & 819 & 484 & 688 \\
\hline Alcoholic beverages and tobacco & 842 & 340 & 647 \\
\hline Spirits & 97 & 31 & 72 \\
\hline Wine & 70 & 29 & 54 \\
\hline Beer & 195 & 65 & 145 \\
\hline Tobacco & 480 & 215 & 377 \\
\hline Clothing and footwear & 3026 & 2396 & 2781 \\
\hline Clothing materials & 17 & 23 & 20 \\
\hline Garments & 2060 & $1621 \mid$ & 1889 \\
\hline
\end{tabular}




\begin{tabular}{|c|c|c|c|}
\hline & Male & Female & ${ }^{*}$ Total \\
\hline Other articles of clothing and clothing accessories & 53 & 36 & 46 \\
\hline Cleaning, repair and hire of clothing & 11 & 9 & 10 \\
\hline Shoes and other footwear & 878 & 702 & 809 \\
\hline Repair and hire of footwear & 6 & 5 & 6 \\
\hline Housing, water, electricity, gas and other fuels & 16035 & 8868 & 13245 \\
\hline Actual rentals paid by tenants & 2424 & 1381 & 2017 \\
\hline Imputed rentals of owner-occupiers & 8770 & 4430 & 7081 \\
\hline Materials for maintenance and repair of the dwelling & 452 & 241 & 370 \\
\hline Service of the maintenance and repair of the dwelling & 822 & 272 & 608 \\
\hline Water and electricity & 665 & 318 & 530 \\
\hline Water supply & 390 & 301 & 356 \\
\hline Refuse collection & 124 & 89 & 110 \\
\hline Sewerage collection & 137 & 110 & 126 \\
\hline Other services relating to the dwelling & 799 & 478 & 675 \\
\hline Electricity & 1152 & 824 & 1024 \\
\hline Gas & 37 & 34 & 36 \\
\hline Liquid fuels & 152 & 185 & 165 \\
\hline Solid fuels & 110 & 204 & 147 \\
\hline Furnishings, household equipment and routine maintenance of the dwelling & 4450 & 2949 & 3868 \\
\hline Furniture and furnishings & 770 & 613 & 709 \\
\hline Carpets and other floor covering & 101 & 58 & 84 \\
\hline Repair of furniture, furnishings and floor covering & 25 & 16 & 22 \\
\hline Household textiles & 734 & 675 & 712 \\
\hline Major household appliances & 508 & 372 & 455 \\
\hline Small electrical household appliances & 83 & 66 & 76 \\
\hline
\end{tabular}




\begin{tabular}{|c|c|c|c|}
\hline & Male & Female & ${ }^{*}$ Total \\
\hline Repair of household appliance & 21 & 16 & 19 \\
\hline Glassware, tableware and household utensils & 115 & 96 & 108 \\
\hline Major tools and equipment & 29 & 9 & 21 \\
\hline Small tools and miscellaneous accessories & 53 & 34 & 46 \\
\hline Non-durable household goods & 486 & 427 & 463 \\
\hline Domestic services and household arcticles & 1525 & 567 & 1154 \\
\hline Health & 1135 & 615 & 933 \\
\hline Pharmaceutical products & 377 & 214 & 314 \\
\hline Other medical products & 13 & 8 & 11 \\
\hline Therapeutic appliances and equipment & 33 & 15 & 26 \\
\hline Medical services & 428 & 258 & 362 \\
\hline Dental services & 65 & 37 & 54 \\
\hline Paramedic services & 80 & 32 & 62 \\
\hline Hospital services & 139 & 51 & 105 \\
\hline Transport & 14272 & 6333 & 11180 \\
\hline Motor cars & 8386 & 3245 & 6383 \\
\hline Motorcycles & 53 & 13 & 37 \\
\hline Bicycles & 15 & 7 & 12 \\
\hline Animal-drawn vehicles & 10 & 1 & 6 \\
\hline Spare parts and accessories & 457 & 153 & 339 \\
\hline Fuels and lubricants & 2598 & 901 & 1939 \\
\hline Maintenance and repair of personal transport equipment & 355 & 112 & 260 \\
\hline Other services in respect of personal transport equipment & 373 & 163 & 291 \\
\hline Passenger transport by rail & 99 & 61 & 84 \\
\hline Passenger transport by road & 1679 & 1594 & 1646 \\
\hline
\end{tabular}




\begin{tabular}{|c|c|c|c|}
\hline & Male & Female & *Total \\
\hline Passenger transport by air & 217 & 67 & 159 \\
\hline Passenger transport by sea and inland waterway & 2 & - & 1 \\
\hline Other puchased transport services & 21 & 14 & 19 \\
\hline Cost for other modes of transport & 6 & 1 & 4 \\
\hline Communication & 2382 & 1322 & 1969 \\
\hline Postal services & 43 & 17 & 33 \\
\hline Telephone and telefax equipment & 249 & 213 & 235 \\
\hline Telephone and telefax services & 2090 & 1093 & 1702 \\
\hline Recreation and culture & 3270 & 1501 & 2582 \\
\hline Equipment for the reception, recording and reproduction of sound and pictures & 488 & 314 & 420 \\
\hline Photographic and cinematographic equipment and optical instruments & 75 & 38 & 61 \\
\hline Information processing equipment & 299 & 141 & 237 \\
\hline Recording media & 144 & 61 & 112 \\
\hline Major durables for outdoor recreation & 29 & 2 & 19 \\
\hline Musical instruments and major durables for outdoor recreation & 21 & 9 & 17 \\
\hline Maintenance and repair of other major durables for recreation and culture & 12 & 7 & 10 \\
\hline Games, toys and hobbies & 84 & 44 & 68 \\
\hline Equipment for sport, camping and open-air recreation & 114 & 32 & 82 \\
\hline Gardens, plants and flowers & 115 & 52 & 90 \\
\hline Pets and related products & 224 & 94 & 174 \\
\hline Veterinary and other services & 57 & 21 & 43 \\
\hline Recreational and sporting services & 200 & 92 & 158 \\
\hline Cultural services & 444 & 184 & 343 \\
\hline Games of chance & 290 & 83 & 209 \\
\hline Books & 125 & 80 & 108 \\
\hline Newspaper and periodicals & 296 & 125 & 229 \\
\hline Miscellaneous printed matter & 10 & 5 & 8 \\
\hline Stationery and drawing materials & 89 & 80 & 85 \\
\hline Package holidays & 154 & 35 & 107 \\
\hline
\end{tabular}




\begin{tabular}{|c|c|c|c|}
\hline & Male & Female & *Total \\
\hline Education & 1588 & 993 & 1356 \\
\hline Pre-primary and primary education & 417 & 221 & 341 \\
\hline Secondary education & 424 & 258 & 359 \\
\hline Tertiary education & 635 & 341 & 520 \\
\hline Education not definable by level & 112 & 174 & 136 \\
\hline Restaurants and hotels & 1579 & 688 & 1232 \\
\hline Beverages in restaurants, cafes, canteens and the like & 270 & 97 & 203 \\
\hline Meals in restaurants, cafes, canteens and the like & 701 & 366 & 571 \\
\hline Accommodation services & 608 & 225 & 459 \\
\hline Miscellaneous goods and services & 9768 & 5436 & 8081 \\
\hline Hairdressing salons and personal grooming establishments & 45 & 38 & 42 \\
\hline Electrical appliances for personal care & 6 & 5 & 6 \\
\hline Other appliances, articles and products for personal care & 701 & 564 & 648 \\
\hline Jewellery, clocks and watches & 171 & 88 & 139 \\
\hline Other personal effects & 129 & 96 & 116 \\
\hline Social protection services & 144 & 87 & 121 \\
\hline Insurance connected with the dwelling & 1944 & 925 & 1547 \\
\hline Insurance connected with health & 2568 & 885 & 1914 \\
\hline Insurance connected with transport & 602 & 261 & 469 \\
\hline Other insurance & 630 & 581 & 610 \\
\hline Financial services n.e.c. & 981 & 491 & 790 \\
\hline Other services & 1847 & 1416 & 1680 \\
\hline Other unclassified expenses & 205 & 121 & 172 \\
\hline Total & 67128 & 38927 & 56152 \\
\hline
\end{tabular}

*Total includes households with unspecified sex of household head

Due to rounding, figures do not necessarily add up to totals 


\section{Expenditure}

Table 2.25 - Average household consumption expenditure by main expenditure group and type of settlement

\begin{tabular}{|c|c|c|c|}
\hline & Urban & Rural & Total \\
\hline Number of households in sample & 11859 & 9285 & 21144 \\
\hline Number of households in population & 8112493 & 4345088 & 12457581 \\
\hline Main expenditure group & \multicolumn{3}{|c|}{ Rand per household per year } \\
\hline Food and non-alcoholic beverages & 9054 & 6334 & 8105 \\
\hline Alcoholic beverages and tobacco & 828 & 311 & 647 \\
\hline Clothing and footwear & 3301 & 1808 & 2781 \\
\hline Housing, water, electricity, gas and other fuels & 18103 & 4175 & 13245 \\
\hline Furnishings, household equipment and routine maintenance of the dwelling & 4737 & 2245 & 3868 \\
\hline Health & 1192 & 449 & 933 \\
\hline Transport & 15076 & 3907 & 11180 \\
\hline Communication & 2589 & 812 & 1969 \\
\hline Recreation and culture & 3537 & 797 & 2582 \\
\hline Education & 1666 & 777 & 1356 \\
\hline Restaurants and hotels & 1632 & 487 & 1232 \\
\hline Miscellaneous goods and services & 10582 & 3413 & 8081 \\
\hline Other unclasified expenses & 232 & 61 & 172 \\
\hline Total & 72529 & 25576 & 56152 \\
\hline
\end{tabular}

Due to rounding, figures do not necessarily add up to totals 


\section{Expenditure}

Table 2.26 - Average household consumption expenditure by secondary expenditure group and type of settlement

\begin{tabular}{|c|c|c|c|}
\hline & Urban & Rural & Total \\
\hline Secondary expenditure group & \multicolumn{2}{|c|}{ Rand per household per year } & \\
\hline Food and non-alcoholic beverages & 9054 & 6334 & 8105 \\
\hline Food & 7403 & 5732 & 6820 \\
\hline Non-alcoholic beverages & 724 & 359 & 597 \\
\hline Unspecified food & 927 & 243 & 688 \\
\hline Alcoholic beverages and tobacco & 828 & 311 & 647 \\
\hline Alcoholic beverages & 342 & 138 & 271 \\
\hline Tobacco & 486 & 173 & 377 \\
\hline Clothing and footwear & 3301 & 1808 & 2781 \\
\hline Clothing & 2334 & 1278 & 1966 \\
\hline Footwear & 968 & 530 & 815 \\
\hline Housing, water, electricity, gas and other fuels & 18103 & 4175 & 13245 \\
\hline Actual rentals for housing & 2803 & 550 & 2017 \\
\hline Imputed rentals for housing & 9806 & 1993 & 7081 \\
\hline Maintenance and repair of the dwelling & 1362 & 261 & 978 \\
\hline Water supply and miscellaneous services relating to the dwelling & 2651 & 204 & 1798 \\
\hline Electricity, gas and other fuels & 1481 & 1167 & 1371 \\
\hline
\end{tabular}




\begin{tabular}{|c|c|c|c|}
\hline & Urban & Rural & Total \\
\hline $\begin{array}{l}\text { Furnishings, household equipment and routine maintenance of the } \\
\text { dwelling }\end{array}$ & 4737 & 2245 & 3868 \\
\hline Furniture and furnishings, carpets and other floor covering & 969 & 525 & 814 \\
\hline Household textiles & 781 & 583 & 712 \\
\hline Household appliances & 655 & 355 & 550 \\
\hline Glassware, tableware and household utensils & 121 & 83 & 108 \\
\hline Tools and equipment for house and garden & 82 & 40 & 67 \\
\hline Goods and services for routine household maintenance & 2129 & 659 & 1617 \\
\hline Health & 1192 & 449 & 933 \\
\hline Medical products, appliances and equipment & 463 & 140 & 351 \\
\hline Out-patient services & 581 & 283 & 477 \\
\hline Hospital services & 147 & 26 & 105 \\
\hline Transport & 15076 & 3907 & 11180 \\
\hline Operation of personal transport equipment & 3876 & 874 & 2829 \\
\hline Transport services & 2179 & 1402 & 1908 \\
\hline Operational values of other modes of transport & 2 & 8 & 4 \\
\hline Communication & 2589 & 812 & 1969 \\
\hline Postal services & 43 & 13 & 33 \\
\hline Telephone and telefax equipment & 260 & 187 & 235 \\
\hline Telephone and telefax services & 2286 & 612 & 1702 \\
\hline Recreation and culture & 3537 & 797 & 2582 \\
\hline Audio-visual, photographic and information processing equipment & 1086 & 353 & 830 \\
\hline Other major durables for recreation and culture & 60 & 18 & 45 \\
\hline Other recreational items and equipment, garden and pets & 646 & 105 & 457 \\
\hline Recreational and cultural services & 1009 & 154 & 711 \\
\hline
\end{tabular}




\begin{tabular}{|c|c|c|c|}
\hline & Urban & Rural & Total \\
\hline Newspapers, books and stationery & 574 & 163 & 431 \\
\hline Package holidays & 163 & 5 & 107 \\
\hline Education & 1666 & 777 & 1356 \\
\hline Pre-primary and primary education & 437 & 161 & 341 \\
\hline Secondary education & 443 & 202 & 359 \\
\hline Education not definable by level & 93 & 216 & 136 \\
\hline Restaurants and hotels & 1632 & 487 & 1232 \\
\hline Catering services & 1014 & 324 & 773 \\
\hline Accommodation services & 618 & 163 & 459 \\
\hline Miscellaneous goods and services & 10582 & 3413 & 8081 \\
\hline Personal care & 894 & 325 & 696 \\
\hline Insurance & 6244 & 1359 & 4540 \\
\hline Financial services n.e.c. & 1024 & 353 & 790 \\
\hline Other services n.e.c. & 1921 & 1228 & 1680 \\
\hline Other unclasified expenses & 232 & 61 & 172 \\
\hline Total & 72529 & 25576 & 56152 \\
\hline
\end{tabular}

Due to rounding, figures do not necessarily add up to totals 


\section{Expenditure}

Table 2.27 - Average household consumption expenditure by third expenditure group and type of settlement

\begin{tabular}{|c|c|c|c|}
\hline & Urban & Rural & Total \\
\hline Number of households in sample & 11859 & 9285 & 21144 \\
\hline Number of households in population & 8112493 & 4345088 & 12457581 \\
\hline Third expenditure group & \multicolumn{3}{|c|}{ Rand per household per year } \\
\hline Food and non-alcoholic beverages & 9054 & 6334 & 8105 \\
\hline Bread and cereals & 1577 & 1898 & 1688 \\
\hline Meat & 2369 & 1425 & 2039 \\
\hline Fish & 346 & 167 & 283 \\
\hline Milk, cheese and eggs & 924 & 502 & 777 \\
\hline Oils and fats & 272 & 246 & 263 \\
\hline Fruits & 245 & 135 & 207 \\
\hline Vegetables & 820 & 680 & 771 \\
\hline Sugar, jam, honey, chocolate and confectionery & 415 & 389 & 406 \\
\hline Food products n.e.c. & 436 & 291 & 386 \\
\hline Coffee, tea and cocoa & 170 & 107 & 148 \\
\hline Mineral waters, soft drinks, fruit and vegetable juices & 554 & 252 & 449 \\
\hline Unspecified food & 927 & 243 & 688 \\
\hline Alcoholic beverages and tobacco & 828 & 311 & 647 \\
\hline Spirits & 98 & 23 & 72 \\
\hline Wine & 74 & 17 & 54 \\
\hline Beer & 170 & 98 & 145 \\
\hline Tobacco & 486 & 173 & 377 \\
\hline
\end{tabular}




\begin{tabular}{|c|c|c|c|}
\hline & Urban & Rural & Total \\
\hline Clothing and footwear & 3301 & 1808 & 2781 \\
\hline Clothing materials & 21 & 16 & 20 \\
\hline Garments & 2243 & 1230 & 1889 \\
\hline Other articles of clothing and clothing accessories & 57 & 26 & 46 \\
\hline Cleaning, repair and hire of clothing & 13 & 6 & 10 \\
\hline Shoes and other footwear & 961 & 525 & 809 \\
\hline Repair and hire of footwear & 6 & 5 & 6 \\
\hline Housing, water, electricity, gas and other fuels & 18103 & 4175 & 13245 \\
\hline Actual rentals paid by tenants & 2803 & 550 & 2017 \\
\hline Imputed rentals of owner-occupiers & 9806 & 1993 & 7081 \\
\hline Materials for maintenance and repair of the dwelling & 508 & 112 & 370 \\
\hline Service of the maintenance and repair of the dwelling & 854 & 149 & 608 \\
\hline Water and electricity & 770 & 83 & 530 \\
\hline Sewerage collection & 191 & 6 & 126 \\
\hline Other services relating to the dwelling & 1011 & 48 & 675 \\
\hline Electricity & 1256 & 592 & 1024 \\
\hline Gas & 31 & 45 & 36 \\
\hline Liquid fuels & 138 & 214 & 165 \\
\hline Solid fuels & 56 & 316 & 147 \\
\hline $\begin{array}{l}\text { Furnishings, household equipment and routine maintenance of the } \\
\text { dwelling }\end{array}$ & 4737 & 2245 & 3868 \\
\hline Furniture and furnishings & 829 & 483 & 709 \\
\hline Carpets and other floor covering & 111 & 34 & 84 \\
\hline Repair of furniture, furnishings and floor covering & 29 & 8 & 22 \\
\hline Household textiles & 781 & 583 & 712 \\
\hline Major household appliances & 535 & 306 & 455 \\
\hline Small electrical household appliances & 96 & 38 & 76 \\
\hline
\end{tabular}




\begin{tabular}{|c|c|c|c|}
\hline & Urban & Rural & Total \\
\hline Repair of household appliance & 23 & 11 & 19 \\
\hline Major tools and equipment & 30 & 5 & 21 \\
\hline Small tools and miscellaneous accessories & 52 & 35 & 46 \\
\hline Non-durable household goods & 523 & 350 & 463 \\
\hline Domestic services and household arcticles & 1606 & 309 & 1154 \\
\hline Health & 1192 & 449 & 933 \\
\hline Pharmaceutical products & 411 & 131 & 314 \\
\hline Other medical products & 14 & 5 & 11 \\
\hline Therapeutic appliances and equipment & 37 & 5 & 26 \\
\hline Medical services & 419 & 254 & 362 \\
\hline Dental services & 76 & 12 & 54 \\
\hline Paramedic services & 86 & 16 & 62 \\
\hline Hospital services & 147 & 26 & 105 \\
\hline Motorcars & 8958 & 1574 & 6383 \\
\hline Motor cycles & 50 & 13 & 37 \\
\hline Bicycles & 9 & 18 & 12 \\
\hline Animal-drawn vehicles & - & 18 & 6 \\
\hline Spare parts and accessories & 448 & 134 & 339 \\
\hline Fuels and lubricants & 2683 & 550 & 1939 \\
\hline Maintenance and repair of personal transport equipment & 364 & 67 & 260 \\
\hline Other services in respect of personal transport equipment & 382 & 122 & 291 \\
\hline Passenger transport by rail & 116 & 25 & 84 \\
\hline Passenger transport by road & 1806 & 1346 & 1646 \\
\hline
\end{tabular}




\begin{tabular}{|c|c|c|c|}
\hline & Urban & Rural & Total \\
\hline Passenger transport by air & 236 & 16 & 159 \\
\hline Other puchased transport services & 20 & 16 & 19 \\
\hline Cost for other modes of transport & 2 & 8 & 4 \\
\hline Communication & 2589 & 812 & 1969 \\
\hline Telephone and telefax equipment & 260 & 187 & 235 \\
\hline Telephone and telefax services & 2286 & 612 & 1702 \\
\hline Recreation and culture & 3537 & 797 & 2582 \\
\hline $\begin{array}{l}\text { Equipment for the reception, recording and reproduction of sound and } \\
\text { pictures }\end{array}$ & 501 & 270 & 420 \\
\hline Photographic and cinematographic equipment and optical instruments & 89 & 8 & 61 \\
\hline Information processing equipment & 342 & 42 & 237 \\
\hline Musical instruments and major durables for outdoor recreation & 19 & 12 & 17 \\
\hline Maintenance and repair of other major durables for recreation and culture & 12 & 6 & 10 \\
\hline Games, toys and hobbies & 101 & 7 & 68 \\
\hline Equipment for sport, camping and open-air recreation & 119 & 14 & 82 \\
\hline Gardens, plants and flowers & 127 & 22 & 90 \\
\hline Pets and related products & 235 & 59 & 174 \\
\hline Veterinary and other services & 64 & 4 & 43 \\
\hline Recreational and sporting services & 229 & 26 & 158 \\
\hline Cultural services & 497 & 55 & 343 \\
\hline Games of chance & 283 & 73 & 209 \\
\hline Books & 142 & 44 & 108 \\
\hline Newspaper and periodicals & 315 & 69 & 229 \\
\hline Miscellaneous printed matter & 12 & 2 & 8 \\
\hline Stationery and drawing materials & 105 & 48 & 85 \\
\hline Package holidays & 163 & 5 & 107 \\
\hline
\end{tabular}




\begin{tabular}{|c|c|c|c|}
\hline & Urban & Rural & Total \\
\hline Education & 1666 & 777 & 1356 \\
\hline Pre-primary and primary education & 437 & 161 & 341 \\
\hline Secondary education & 443 & 202 & 359 \\
\hline Tertiary education & 693 & 198 & 520 \\
\hline Education not definable by level & 93 & 216 & 136 \\
\hline Restaurants and hotels & 1632 & 487 & 1232 \\
\hline Beverages in restaurants, cafes, canteens and the like & 240 & 133 & 203 \\
\hline Meals in restaurants, cafes, canteens and the like & 774 & 191 & 571 \\
\hline Accommodation services & 618 & 163 & 459 \\
\hline Miscellaneous goods and services & 10582 & 3413 & 8081 \\
\hline Hairdressing salons and personal grooming establishments & 60 & 10 & 42 \\
\hline Electrical appliances for personal care & 7 & 2 & 6 \\
\hline Jewellery, clocks and watches & 184 & 54 & 139 \\
\hline Other personal effects & 145 & 61 & 116 \\
\hline Social protection services & 169 & 33 & 121 \\
\hline Insurance connected with the dwelling & 2208 & 312 & 1547 \\
\hline Insurance connected with health & 2680 & 483 & 1914 \\
\hline Insurance connected with transport & 670 & 94 & 469 \\
\hline Other insurance & 686 & 470 & 610 \\
\hline Financial services n.e.c. & 1024 & 353 & 790 \\
\hline Other services & 1921 & 1228 & 1680 \\
\hline Other unclasified expenses & 232 & 61 & 172 \\
\hline Total & 72529 & 25576 & 56152 \\
\hline
\end{tabular}

Due to rounding, figures do not necessarily add up to totals 


\section{Expenditure}

Table 2.28 - Average household consumption expenditure by main expenditure group and expenditure deciles

\begin{tabular}{|c|c|c|c|c|c|c|c|c|c|c|c|}
\hline & \multicolumn{10}{|c|}{ Expenditure deciles } & \multirow[t]{2}{*}{ Total } \\
\hline & Lower & 2 & 3 & 4 & 5 & 6 & 7 & 8 & 9 & Upper & \\
\hline Average household size & 2,6 & 3,4 & 4,0 & 4,3 & 4,6 & 4,8 & 4,7 & 4,5 & 3,9 & 3,5 & 3,8 \\
\hline Main expenditure group & \multicolumn{11}{|c|}{ Rand per household per year } \\
\hline Food and non-alcoholic beverages & 2077 & 3497 & 4498 & 5435 & 6421 & 7457 & 8733 & 10524 & 12662 & 19731 & 8105 \\
\hline Alcoholic beverages and tobacco & 195 & 249 & 267 & 344 & 419 & 507 & 706 & 792 & 1234 & 1758 & 647 \\
\hline Clothing and footwear & 543 & 906 & 1175 & 1550 & 1810 & 2226 & 2807 & 3749 & 4902 & 8129 & 2781 \\
\hline $\begin{array}{l}\text { Housing, water, electricity, gas and other } \\
\text { fuels }\end{array}$ & 1214 & 1895 & 2464 & 3078 & 3897 & 4807 & 6907 & 12129 & 26545 & 69414 & 13245 \\
\hline $\begin{array}{l}\text { Furnishings, household equipment and } \\
\text { routine maintenance of the dwelling }\end{array}$ & 280 & 555 & 906 & 1217 & 1628 & 2268 & 3164 & 4401 & 6551 & 17683 & 3868 \\
\hline Health & 98 & 162 & 211 & 292 & 321 & 393 & 524 & 966 & 1438 & 4914 & 933 \\
\hline Transport & 472 & 833 & 1203 & 1658 & 2017 & 2674 & 3913 & 6730 & 14447 & 77729 & 11180 \\
\hline Communication & 162 & 317 & 464 & 580 & 764 & 975 & 1368 & 2089 & 3943 & 9019 & 1969 \\
\hline Recreation and culture & 86 & 199 & 343 & 471 & 671 & 1005 & 1441 & 2279 & 4186 & 15112 & 2582 \\
\hline Education & 53 & 108 & 136 & 225 & 266 & 516 & 685 & 1322 & 3095 & 7147 & 1356 \\
\hline Restaurants and hotels & 202 & 270 & 419 & 366 & 478 & 704 & 1012 & 1087 & 2059 & 5722 & 1232 \\
\hline Miscellaneous goods and services & 360 & 774 & 1073 & 1434 & 2092 & 2938 & 4229 & 7566 & 15507 & 44775 & 8081 \\
\hline Other unclassified expenses & 9 & 18 & 27 & 40 & 48 & 66 & 93 & 154 & 281 & 984 & 172 \\
\hline Total & 5749 & 9784 & 13185 & 16691 & 20831 & 26536 & 35581 & 53788 & 96851 & 282119 & 56152 \\
\hline
\end{tabular}

Due to rounding, figures do not necessarily add up to totals 


\section{Expenditure}

Table 2.29 - Average household consumption expenditure by secondary expenditure group and expenditure deciles

\begin{tabular}{|c|c|c|c|c|c|c|c|c|c|c|c|}
\hline & \multicolumn{10}{|c|}{ Expenditure deciles } & \multirow[t]{2}{*}{ Total } \\
\hline & Lower & 2 & 3 & 4 & 5 & 6 & 7 & 8 & 9 & Upper & \\
\hline Average household size & 2,6 & 3,4 & 4,0 & 4,3 & 4,6 & 4,8 & 4,7 & 4,5 & 3,9 & 3,5 & 3,8 \\
\hline Secondary expenditure group & \multicolumn{11}{|c|}{ Rand per household per year } \\
\hline Food and non-alcoholic beverages & 2077 & 3497 & 4498 & 5435 & 6421 & 7457 & 8733 & 10524 & 12662 & 19731 & 8105 \\
\hline Food & 1936 & 3233 & 4146 & 4970 & 5820 & 6701 & 7745 & 9119 & 10450 & 14069 & 6820 \\
\hline Non-alcoholic beverages & 107 & 194 & 245 & 305 & 407 & 491 & 616 & 788 & 1087 & 1726 & 597 \\
\hline Unspecified food & 34 & 70 & 107 & 160 & 193 & 265 & 372 & 616 & 1125 & 3936 & 688 \\
\hline Alcoholic beverages and tobacco & 195 & 249 & 267 & 344 & 419 & 507 & 706 & 792 & 1234 & 1758 & 647 \\
\hline Alcoholic beverages & 70 & 85 & 76 & 137 & 152 & 211 & 271 & 304 & 527 & 874 & 271 \\
\hline Tobacco & 125 & 164 & 191 & 207 & 267 & 296 & 435 & 489 & 708 & 885 & 377 \\
\hline Clothing and footwear & 543 & 906 & 1175 & 1550 & 1810 & 2226 & 2807 & 3749 & 4902 & 8129 & 2781 \\
\hline Clothing & 370 & 626 & 795 & 1086 & 1249 & 1526 & 1974 & 2670 & 3546 & 5808 & 1966 \\
\hline Footwear & 173 & 281 & 381 & 464 & 561 & 700 & 833 & 1079 & 1356 & 2321 & 815 \\
\hline Housing, water, electricity, gas and other fuels & 1214 & 1895 & 2464 & 3078 & 3897 & 4807 & 6907 & 12129 & 26545 & 69414 & 13245 \\
\hline Actual rentals for housing & 255 & 356 & 492 & 602 & 831 & 991 & 1681 & 3056 & 5890 & 6011 & 2017 \\
\hline Imputed rentals for housing & 443 & 691 & 910 & 1096 & 1397 & 1833 & 2549 & 4871 & 13393 & 43562 & 7081 \\
\hline Maintenance and repair of the dwelling & 17 & 24 & 47 & 96 & 94 & 145 & 268 & 502 & 969 & 7603 & 978 \\
\hline $\begin{array}{l}\text { Water supply and miscellaneous services relating to } \\
\text { the dwelling }\end{array}$ & 84 & 170 & 221 & 371 & 514 & 613 & 1038 & 2101 & 3921 & 8932 & 1798 \\
\hline Electricity, gas and other fuels & 415 & 654 & 794 & 913 & 1061 & 1225 & 1371 & 1600 & 2372 & 3306 & 1371 \\
\hline
\end{tabular}




\begin{tabular}{|c|c|c|c|c|c|c|c|c|c|c|c|}
\hline & \multicolumn{10}{|c|}{ Expenditure deciles } & \multirow[t]{2}{*}{ Total } \\
\hline & Lower & 2 & 3 & 4 & 5 & 6 & 7 & 8 & 9 & Upper & \\
\hline $\begin{array}{l}\text { Furnishings, household equipment and routine } \\
\text { maintenance of the dwelling }\end{array}$ & 280 & 555 & 906 & 1217 & 1628 & 2268 & 3164 & 4401 & 6551 & 17683 & 3868 \\
\hline $\begin{array}{l}\text { Furniture and furnishings, carpets and other floor } \\
\text { covering }\end{array}$ & 15 & 39 & 137 & 164 & 318 & 491 & 838 & 1175 & 1439 & 3519 & 814 \\
\hline Household textiles & 89 & 197 & 260 & 409 & 451 & 635 & 828 & 1086 & 1284 & 1878 & 712 \\
\hline Household appliances & 23 & 57 & 154 & 221 & 361 & 576 & 687 & 830 & 940 & 1652 & 550 \\
\hline Glassware, tableware and household utensils & 13 & 27 & 37 & 54 & 61 & 78 & 105 & 142 & 209 & 352 & 108 \\
\hline Tools and equipment for house and garden & 10 & 14 & 22 & 21 & 22 & 32 & 29 & 52 & 100 & 369 & 67 \\
\hline Goods and services for routine household & 130 & 223 & 296 & 349 & 416 & 455 & 677 & 1115 & 2578 & 9913 & 1617 \\
\hline Health & 98 & 162 & 211 & 292 & 321 & 393 & 524 & 966 & 1438 & 4914 & 933 \\
\hline Medical products, appliances and equipment & 41 & 58 & 76 & 103 & 122 & 149 & 196 & 348 & 614 & 1797 & 351 \\
\hline Out-patient services & 53 & 102 & 131 & 183 & 193 & 234 & 316 & 512 & 657 & 2388 & 477 \\
\hline Hospital services & 4 & 3 & 4 & 6 & 6 & 10 & 12 & 107 & 167 & 729 & 105 \\
\hline Transport & 472 & 833 & 1203 & 1658 & 2017 & 2674 & 3913 & 6730 & 14447 & 77729 & 11180 \\
\hline Purchase of vehicles & 5 & 4 & 12 & 31 & 34 & 62 & 199 & 1071 & 3963 & 58904 & 6439 \\
\hline Operation of personal transport equipment & 5 & 41 & 58 & 119 & 183 & 337 & 923 & 2719 & 7751 & 16131 & 2829 \\
\hline Transport services & 462 & 787 & 1132 & 1506 & 1799 & 2273 & 2790 & 2938 & 2732 & 2663 & 1908 \\
\hline Operational values of other modes of transport & & 1 & 1 & 2 & 1 & 3 & 1 & 2 & 1 & 31 & 4 \\
\hline Communication & 162 & 317 & 464 & 580 & 764 & 975 & 1368 & 2089 & 3943 & 9019 & 1969 \\
\hline Postal services & 1 & 2 & 4 & 5 & 6 & 10 & 15 & 36 & 69 & 176 & 33 \\
\hline Telephone and telefax equipment & 38 & 70 & 115 & 130 & 181 & 205 & 297 & 327 & 470 & 514 & 235 \\
\hline Telephone and telefax services & 123 & 245 & 344 & 446 & 576 & 760 & 1055 & 1726 & 3404 & 8329 & 1702 \\
\hline Recreation and culture & 86 & 199 & 343 & 471 & 671 & 1005 & 1441 & 2279 & 4186 & 15112 & 2582 \\
\hline $\begin{array}{l}\text { Audio-visual, photographic and information } \\
\text { processing equipment }\end{array}$ & 25 & 67 & 149 & 219 & 341 & 529 & 663 & 987 & 1429 & 3888 & 830 \\
\hline Other major durables for recreation and culture & 1 & 2 & 5 & 5 & 8 & 17 & 16 & 33 & 89 & 277 & 45 \\
\hline $\begin{array}{l}\text { Other recreational items and equipment, garden and } \\
\text { pets }\end{array}$ & 7 & 17 & 19 & 27 & 37 & 51 & 87 & 208 & 665 & 3448 & 457 \\
\hline Recreational and cultural services & 26 & 61 & 88 & 106 & 148 & 182 & 330 & 500 & 1033 & 4627 & 711 \\
\hline Newspapers, books and stationery & 27 & 51 & 81 & 106 & 131 & 189 & 310 & 518 & 814 & 2078 & 431 \\
\hline Package holidays & & & 1 & 7 & 6 & 38 & 35 & 34 & 155 & 795 & 107 \\
\hline
\end{tabular}




\begin{tabular}{|c|c|c|c|c|c|c|c|c|c|c|c|}
\hline & \multicolumn{10}{|c|}{ Expenditure deciles } & \multirow[t]{2}{*}{ Total } \\
\hline & Lower & 2 & 3 & 4 & 5 & 6 & 7 & 8 & 9 & Upper & \\
\hline Education & 53 & 108 & 136 & 225 & 266 & 516 & 685 & 1322 & 3095 & 7147 & 1356 \\
\hline Pre-primary and primary education & 23 & 48 & 59 & 70 & 85 & 126 & 164 & 331 & 762 & 1736 & 341 \\
\hline Secondary education & 27 & 46 & 56 & 68 & 84 & 137 & 187 & 298 & 591 & 2095 & 359 \\
\hline Tertiary education & 2 & 11 & 15 & 74 & 81 & 234 & 309 & 662 & 1677 & 2135 & 520 \\
\hline Education not definable by level & 1 & 3 & 5 & 12 & 15 & 18 & 25 & 32 & 66 & 1181 & 136 \\
\hline Restaurants and hotels & 202 & 270 & 419 & 366 & 478 & 704 & 1012 & 1087 & 2059 & 5722 & 1232 \\
\hline Catering services & 191 & 254 & 393 & 327 & 429 & 620 & 866 & 793 & 1180 & 2676 & 773 \\
\hline Accommodation services & 11 & 15 & 26 & 38 & 48 & 84 & 146 & 294 & 879 & 3046 & 459 \\
\hline Miscellaneous goods and services & 360 & 774 & 1073 & 1434 & 2092 & 2938 & 4229 & 7566 & 15507 & 44775 & 8081 \\
\hline Personal care & 108 & 193 & 246 & 293 & 402 & 490 & 682 & 861 & 1283 & 2396 & 696 \\
\hline Personal effects & 21 & 39 & 47 & 68 & 91 & 115 & 168 & 232 & 403 & 1363 & 255 \\
\hline Social protection & 8 & 10 & 23 & 33 & 34 & 48 & 77 & 160 & 231 & 590 & 121 \\
\hline Insurance & 125 & 217 & 281 & 362 & 471 & 722 & 1147 & 3232 & 8736 & 30057 & 4540 \\
\hline Financial services n.e.c. & 20 & 82 & 119 & 154 & 220 & 293 & 459 & 739 & 1623 & 4186 & 790 \\
\hline Other services n.e.c. & 79 & 233 & 357 & 523 & 874 & 1270 & 1695 & 2343 & 3232 & 6183 & 1680 \\
\hline Other unclassified expenses & 9 & 18 & 27 & 40 & 48 & 66 & 93 & 154 & 281 & 984 & 172 \\
\hline Total & 5749 & 9784 & 13185 & 16691 & 20831 & 26536 & 35581 & 53788 & 96851 & 282119 & 56152 \\
\hline
\end{tabular}




\section{Expenditure}

Table 2.30 - Average household consumption expenditure by third expenditure group and expenditure deciles

\begin{tabular}{|c|c|c|c|c|c|c|c|c|c|c|c|}
\hline & & & & ExpeI & ture dec & & & & & & Total \\
\hline & Lower & 2 & 3 & 4 & 5 & 6 & 7 & 8 & \begin{tabular}{l|l}
9 \\
\end{tabular} & Upper & \\
\hline Average household size & 2,6 & 3,4 & 4,0 & 4,3 & 4,6 & 4,8 & 4,7 & 4,5 & 3,9 & 3,5 & 3,8 \\
\hline Third expenditure group & & & & & ind per & isehold & year & & & & \\
\hline Food and non-alcoholic beverages & 2077 & 3497 & 4498 & 5435 & 6421 & 7457 & 8733 & 10524 & 12662 & 19731 & 8105 \\
\hline Bread and cereals & 705 & 1085 & 1369 & 1615 & 1765 & 1983 & 2078 & 2160 & 1960 & 2166 & 1688 \\
\hline Meat & 400 & 757 & 975 & 1260 & 1551 & 1907 & 2386 & 3075 & 3626 & 4456 & 2039 \\
\hline Fish & 68 & 94 & 140 & 164 & 193 & 190 & 294 & 315 & 498 & 875 & 283 \\
\hline Milk, cheese and eggs & 155 & 285 & 359 & 466 & 565 & 674 & 827 & 1070 & 1409 & 1955 & 777 \\
\hline Oils and fats & 91 & 148 & 192 & 212 & 250 & 283 & 299 & 360 & 355 & 436 & 263 \\
\hline Fruits & 34 & 56 & 80 & 94 & 125 & 141 & 164 & 233 & 377 & 762 & 207 \\
\hline Vegetables & 278 & 422 & 529 & 593 & 668 & 730 & 809 & 907 & 1116 & 1655 & 771 \\
\hline Sugar, jam, honey, chocolate and confectionery & 134 & 216 & 288 & 309 & 354 & 393 & 442 & 476 & 536 & 911 & 406 \\
\hline Food products n.e.c. & 71 & 170 & 216 & 255 & 348 & 400 & 446 & 524 & 572 & 853 & 386 \\
\hline Coffee, tea and cocoa & 43 & 72 & 89 & 100 & 115 & 133 & 149 & 172 & 224 & 383 & 148 \\
\hline Mineral waters, soft drinks, fruit and vegetable juices & 64 & 121 & 156 & 205 & 292 & 358 & 467 & 616 & 863 & 1343 & 449 \\
\hline Unspecified food & 34 & 70 & 107 & 160 & 193 & 265 & 372 & 616 & 1125 & 3936 & 688 \\
\hline Alcoholic beverages and tobacco & 195 & 249 & 267 & 344 & 419 & 507 & 706 & 792 & 1234 & 1758 & 647 \\
\hline Spirits & 5 & 6 & 11 & 16 & 24 & 37 & 55 & 105 & 141 & 320 & 72 \\
\hline Wine & 5 & 5 & 12 & 24 & 9 & 13 & 25 & 38 & 96 & 311 & 54 \\
\hline Beer & 60 & 74 & 53 & 97 & 119 & 161 & 191 & 160 & 289 & 243 & 145 \\
\hline Tobacco & 125 & 164 & 191 & 207 & 267 & 296 & 435 & 489 & 708 & 885 & 377 \\
\hline
\end{tabular}




\begin{tabular}{|c|c|c|c|c|c|c|c|c|c|c|c|}
\hline & & & & Expe & ture dec & & & & & & Total \\
\hline & Lower & 2 & 3 & 4 & 5 & 6 & 7 & 8 & 9 & Upper & \\
\hline Clothing and footwear & 543 & 906 & 1175 & 1550 & 1810 & 2226 & 2807 & 3749 & 4902 & 8129 & 2781 \\
\hline Clothing materials & 1 & 5 & 6 & 16 & 10 & 15 & 17 & 25 & 38 & 64 & 20 \\
\hline Garments & 362 & 606 & 771 & 1045 & 1207 & 1474 & 1911 & 2572 & 3403 & 5539 & 1889 \\
\hline Other articles of clothing and clothing accessories & 6 & 12 & 15 & 21 & 25 & 30 & 35 & 57 & 89 & 170 & 46 \\
\hline Cleaning, repair and hire of clothing & 1 & 2 & 3 & 4 & 8 & 6 & 11 & 16 & 16 & 36 & 10 \\
\hline Shoes and other footwear & 171 & 278 & 378 & 460 & 556 & 692 & 825 & 1072 & 1347 & 2313 & 809 \\
\hline Repair and hire of footwear & 2 & 3 & 3 & 4 & 5 & 8 & 7 & 7 & 9 & & 6 \\
\hline Housing, water, electricity, gas and other fuels & 1214 & 1895 & 2464 & 3078 & 3897 & 4807 & 6907 & 12129 & 26545 & 69414 & 13245 \\
\hline Actual rentals paid by tenants & 255 & 356 & 492 & 602 & 831 & 991 & 1681 & 3056 & 5890 & 6011 & 2017 \\
\hline Imputed rentals of owner-occupiers & 443 & 691 & 910 & 1096 & 1397 & 1833 & 2549 & 4871 & 13393 & 43562 & 7081 \\
\hline Materials for maintenance and repair of the dwelling & 10 & 15 & 25 & 35 & 41 & 65 & 108 & 199 & 352 & 2844 & 370 \\
\hline Service of the maintenance and repair of the dwelling & 8 & 9 & 23 & 61 & 53 & 80 & 160 & 302 & 617 & 4759 & 608 \\
\hline Water and electricity & 10 & 24 & 43 & 68 & 92 & 98 & 240 & 740 & 1278 & 2705 & 530 \\
\hline Water supply & 25 & 51 & 67 & 114 & 165 & 218 & 299 & 445 & 746 & 1423 & 356 \\
\hline Refuse collection & 15 & 32 & 38 & 54 & 68 & 77 & 104 & 148 & 237 & 330 & 110 \\
\hline Sewerage collection & 13 & 27 & 27 & 46 & 55 & 59 & 101 & 154 & 241 & 542 & 126 \\
\hline Other services relating to the dwelling & 21 & 36 & 45 & 89 & 133 & 162 & 295 & 614 & 1418 & 3931 & 675 \\
\hline Electricity & 162 & 267 & 378 & 471 & 587 & 778 & 974 & 1367 & 2158 & 3098 & 1024 \\
\hline Gas & 1 & 12 & 11 & 18 & 27 & 36 & 42 & 38 & 89 & 84 & 36 \\
\hline Liquid fuels & 149 & 209 & 214 & 246 & 222 & 208 & 164 & 115 & 75 & 43 & 165 \\
\hline Solid fuels & 103 & 166 & 191 & 178 & 225 & 203 & 191 & 79 & 50 & 81 & 147 \\
\hline $\begin{array}{l}\text { Furnishings, household equipment and routine } \\
\text { maintenance of the dwelling }\end{array}$ & 280 & 555 & 906 & 1217 & 1628 & 2268 & 3164 & 4401 & 6551 & 17683 & 3868 \\
\hline Furniture and furnishings & 12 & 31 & 126 & 152 & 294 & 455 & 792 & 1078 & 1261 & 2882 & 709 \\
\hline Carpets and other floor covering & 2 & 8 & 9 & 9 & 19 & 27 & 38 & 89 & 145 & 492 & 84 \\
\hline Repair of furniture, furnishings and floor covering & 1 & - & 2 & 3 & 5 & 9 & 8 & 8 & 34 & 145 & 22 \\
\hline Household textiles & 89 & 197 & 260 & 409 & 451 & 635 & 828 & 1086 & 1284 & 1878 & 712 \\
\hline Major household appliances & 11 & 36 & 123 & 177 & 304 & 508 & 591 & 702 & 780 & 1317 & 455 \\
\hline Small electrical household appliances & 11 & 19 & 27 & 38 & 48 & 59 & 76 & 105 & 130 & 247 & 76 \\
\hline
\end{tabular}




\begin{tabular}{|c|c|c|c|c|c|c|c|c|c|c|c|}
\hline & & & & Expe & ture de & & & & & & Total \\
\hline & Lower & 2 & 3 & 4 & 5 & 6 & 7 & 8 & 9 & Upper & \\
\hline Repair of household appliances & 1 & 2 & 3 & 5 & 8 & 9 & 20 & 22 & 30 & 88 & 19 \\
\hline Glassware, tableware and household utensils & 13 & 27 & 37 & 54 & 61 & 78 & 105 & 142 & 209 & 352 & 108 \\
\hline Major tools and equipment & - & - & 1 & - & 1 & 2 & 3 & 18 & 28 & 159 & 21 \\
\hline Small tools and miscellaneous accessories & 10 & 13 & 21 & 21 & 21 & 29 & 26 & 35 & 72 & 210 & 46 \\
\hline Non-durable household goods & 127 & 213 & 272 & 302 & 369 & 415 & 478 & 564 & 698 & 1191 & 463 \\
\hline Domestic services and household arcticles & 3 & 9 & 24 & 47 & 47 & 41 & 200 & 551 & 1880 & 8722 & 1154 \\
\hline Health & 98 & 162 & 211 & 292 & 321 & 393 & 524 & 966 & 1438 & 4914 & 933 \\
\hline Pharmaceutical products & 38 & 56 & 71 & 96 & 115 & 142 & 179 & 310 & 548 & 1578 & 314 \\
\hline Other medical products & 2 & 2 & 3 & 5 & 5 & 6 & 8 & 14 & 13 & 52 & 11 \\
\hline Therapeutic appliances and equipment & 1 & - & 1 & 3 & 1 & 2 & 9 & 23 & 54 & 167 & 26 \\
\hline Medical services & 49 & 96 & 123 & 171 & 181 & 220 & 286 & 409 & 511 & 1568 & 362 \\
\hline Dental services & 1 & 3 & 2 & 8 & 5 & 7 & 14 & 23 & 84 & 392 & 54 \\
\hline Paramedic services & 2 & 4 & 5 & 4 & 7 & 7 & 17 & 80 & 62 & 429 & 62 \\
\hline Hospital services & 4 & 3 & 4 & 6 & 6 & 10 & 12 & 107 & 167 & 729 & 105 \\
\hline Transport & 472 & 833 & 1203 & 1658 & 2017 & 2674 & 3913 & 6730 & 14447 & 77729 & 11180 \\
\hline Motor cars & 2 & 1 & 10 & 27 & 28 & 54 & 194 & 1065 & 3926 & 58420 & 6383 \\
\hline Motorcycles & 1 & - & 1 & 1 & & 4 & 1 & 3 & 13 & 352 & 37 \\
\hline Bicycles & 1 & 1 & 1 & 2 & 3 & 1 & 3 & 2 & 24 & 84 & 12 \\
\hline Animal-drawn vehicles & 1 & 1 & 1 & 2 & 3 & 3 & 1 & 1 & & 48 & 6 \\
\hline Spare parts and accessories & 1 & 3 & 2 & 16 & 27 & 41 & 130 & 365 & 938 & 1861 & 339 \\
\hline Fuels and lubricants & 1 & 9 & 14 & 61 & 86 & 203 & 609 & 1860 & 5431 & 11099 & 1939 \\
\hline Maintenance and repairs of personal transport equipment & - & 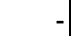 & - & 3 & 16 & 9 & 57 & 203 & 665 & 1646 & 260 \\
\hline Other services in respect of personal transport equipment & 3 & 29 & 42 & 38 & 54 & 84 & 127 & 291 & 717 & 1525 & 291 \\
\hline Passenger transport by rail & 27 & 50 & 82 & 106 & 119 & 101 & 129 & 108 & 82 & 37 & 84 \\
\hline Passenger transport by road & 431 & 735 & 1043 & 1397 & 1670 & 2157 & 2631 & 2791 & 2385 & 1218 & 1646 \\
\hline
\end{tabular}




\begin{tabular}{|c|c|c|c|c|c|c|c|c|c|c|c|}
\hline & & & & Expe & Ire dec & & & & & & Total \\
\hline & Lower & 2 & 3 & 4 & 5 & 6 & 7 & 8 & 9 & Upper & \\
\hline Passenger transport by air & - & - & - & 1 & - & 4 & 6 & 22 & 228 & 1327 & 159 \\
\hline Passenger transport by sea and inland waterway & - & - & - & - & - & - & - & 1 & - & 11 & 1 \\
\hline Other puchased transport services & 3 & 2 & 7 & 3 & 10 & 11 & 24 & 16 & 37 & 70 & 19 \\
\hline Cost for other modes of transport & & 1 & 1 & 2 & 1 & 3 & 1 & 2 & 1 & 31 & 4 \\
\hline Communication & 162 & 317 & 464 & 580 & 764 & 975 & 1368 & 2089 & 3943 & 9019 & 1969 \\
\hline Postal services & 1 & 2 & 4 & 5 & 6 & 10 & 15 & 36 & 69 & 176 & 33 \\
\hline Telephone and telefax equipment & 38 & 70 & 115 & 130 & 181 & 205 & 297 & 327 & 470 & 514 & 235 \\
\hline Telephone and telefax services & 123 & 245 & 344 & 446 & 576 & 760 & 1055 & 1726 & 3404 & 8329 & 1702 \\
\hline Recreation and culture & 86 & 199 & 343 & 471 & 671 & 1005 & 1441 & 2279 & 4186 & 15112 & 2582 \\
\hline $\begin{array}{l}\text { Equipment for the reception, recording and reproduction of } \\
\text { sound and pictures }\end{array}$ & 22 & 60 & 120 & 198 & 301 & 467 & 564 & 697 & 692 & 1080 & 420 \\
\hline $\begin{array}{l}\text { Photographic and cinematographic equipment and optical } \\
\text { instruments }\end{array}$ & & & 3 & & 1 & 3 & 8 & 13 & 114 & 464 & 61 \\
\hline Information processing equipment & 1 & 3 & 11 & 7 & 13 & 22 & 26 & 152 & 407 & 1729 & 237 \\
\hline Recording media & 2 & 4 & 15 & 13 & 26 & 37 & 66 & 126 & 216 & 615 & 112 \\
\hline Major durables for outdoor recreation & - & - & - & - & 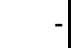 & - & - & - & 16 & 169 & 19 \\
\hline Musical instruments and major durables for outdoor recreation & - & - & 2 & 1 & 2 & 7 & 5 & 22 & 62 & 64 & 17 \\
\hline $\begin{array}{l}\text { Maintenance and repair of other major durables for recreation } \\
\text { and culture }\end{array}$ & 1 & 2 & 3 & 5 & 6 & 9 & 10 & 11 & 11 & 43 & 10 \\
\hline Games, toys and hobbies & 1 & 3 & 1 & 2 & 6 & 9 & 11 & 22 & 97 & 529 & 68 \\
\hline Equipment for sport, camping and open-air recreation & 1 & 1 & 1 & 8 & 4 & 5 & 9 & 21 & 66 & 704 & 82 \\
\hline Gardens, plants and flowers & 2 & 3 & 3 & 4 & 9 & 5 & 10 & 25 & 110 & 728 & 90 \\
\hline Pets and related products & 3 & 9 & 13 & 13 & 17 & 30 & 57 & 129 & 336 & 1127 & 174 \\
\hline Veterinary and other services & - & - & - & 1 & - & - & 1 & 11 & 56 & 358 & 43 \\
\hline Recreational and sporting services & 4 & 9 & 13 & 12 & 14 & 23 & 48 & 98 & 191 & 1168 & 158 \\
\hline Cultural services & 4 & 8 & 19 & 27 & 44 & 61 & 99 & 219 & 567 & 2380 & 343 \\
\hline Games of chance & 18 & 44 & 56 & 67 & 90 & 99 & 183 & 183 & 276 & 1078 & 209 \\
\hline Books & 3 & 6 & 9 & 11 & 20 & 33 & 48 & 96 & 242 & 610 & 108 \\
\hline Newspaper and periodicals & 11 & 23 & 38 & 52 & 69 & 98 & 194 & 320 & 398 & 1087 & 229 \\
\hline Miscellaneous printed matter & - & - & 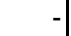 & 1 & 1 & 2 & 2 & 7 & 14 & 58 & 8 \\
\hline Stationery and drawing materials & 13 & 22 & 33 & 42 & 42 & 56 & 66 & 96 & 161 & 323 & 85 \\
\hline Package holidays & & & 1 & 7 & 6 & 38 & 35 & 34 & 155 & 795 & 107 \\
\hline
\end{tabular}




\begin{tabular}{|c|c|c|c|c|c|c|c|c|c|c|c|}
\hline & \multicolumn{10}{|c|}{ Expenditure deciles } & \multirow[t]{2}{*}{ Total } \\
\hline & Lower & 2 & 3 & 4 & 5 & 6 & 7 & 8 & 9 & Upper & \\
\hline Education & 53 & 108 & 136 & 225 & 266 & 516 & 685 & 1322 & 3095 & $\begin{array}{ll}7147 \\
\end{array}$ & 1356 \\
\hline Pre-primary and primary education & 23 & 48 & 59 & 70 & 85 & 126 & 164 & 331 & 762 & 1736 & 341 \\
\hline Secondary education & 27 & 46 & 56 & 68 & 84 & 137 & 187 & 298 & 591 & 2095 & 359 \\
\hline Tertiary education & 2 & 11 & 15 & 74 & 81 & 234 & 309 & 662 & 1677 & 2135 & 520 \\
\hline Education not definable by level & 1 & 3 & 5 & 12 & 15 & 18 & 25 & 32 & 66 & 1181 & 136 \\
\hline Restaurants and hotels & 202 & 270 & 419 & 366 & 478 & 704 & 1012 & 1087 & 2059 & 5722 & 1232 \\
\hline Beverages in restaurants, cafes, canteens and the like & 82 & 111 & 176 & 140 & 201 & 227 & 240 & 298 & 214 & 339 & 203 \\
\hline Meals in restaurants, cafes, canteens and the like & 110 & 144 & 217 & 188 & 228 & 393 & 626 & 495 & 966 & 2337 & 571 \\
\hline Accommodation services & 11 & 15 & 26 & 38 & 48 & 84 & 146 & 294 & 879 & 3046 & 459 \\
\hline Miscellaneous goods and services & 360 & 774 & 1073 & 1434 & 2092 & 2938 & 4229 & 7566 & 15507 & 44775 & 8081 \\
\hline Hairdressing salons and personal grooming establishment & & 3 & 4 & 4 & 4 & 9 & 20 & 26 & 72 & 277 & 42 \\
\hline Electrical appliances for personal care & & & 1 & 2 & 1 & 6 & 4 & 6 & 6 & 30 & 6 \\
\hline Other appliances, articles and products for personal care & 107 & 190 & 240 & 287 & 397 & 475 & 658 & 828 & 1205 & 2090 & 648 \\
\hline Jewellery, clocks and watches & 7 & 14 & 15 & 23 & 37 & 46 & 79 & 116 & 218 & 831 & 139 \\
\hline Other personal effects & 14 & 25 & 33 & 45 & 54 & 69 & 89 & 116 & 185 & 531 & 116 \\
\hline Social protection services & 8 & 10 & 23 & 33 & 34 & 48 & 77 & 160 & 231 & 590 & 121 \\
\hline Insurance connected with the dwelling & - & 1 & - & 2 & 8 & 17 & 43 & 432 & 2088 & 12854 & 1547 \\
\hline Insurance connected with health & 1 & 2 & 16 & 11 & 33 & 135 & 359 & 1652 & 4529 & 12377 & 1914 \\
\hline Insurance connected with transport & - & 4 & - & - & 2 & 2 & 21 & 131 & 858 & 3668 & 469 \\
\hline Other insurance & 124 & 211 & 265 & 349 & 428 & 568 & 723 & 1017 & 1260 & 1159 & 610 \\
\hline Financial services n.e.c. & 20 & 82 & 119 & 154 & 220 & 293 & 459 & 739 & 1623 & 4186 & 790 \\
\hline Other services & 79 & 233 & 357 & 523 & 874 & 1270 & 1695 & 2343 & 3232 & 6183 & 1680 \\
\hline Other unclassified expenses & 9 & 18 & 27 & 40 & 48 & 66 & 93 & 154 & 281 & 984 & 172 \\
\hline Total & 5749 & 9784 & 13185 & 16691 & 20831 & 26536 & 35581 & 53788 & 96851 & 282119 & 56152 \\
\hline
\end{tabular}

Due to rounding, figures do not necessarily add up to totals

- No expenditure 


\section{Expenditure}

Table 2.31 - Average household consumption expenditure by main expenditure group and income deciles

\begin{tabular}{|c|c|c|c|c|c|c|c|c|c|c|c|}
\hline & \multicolumn{10}{|c|}{ Income deciles } & \multirow[t]{2}{*}{ Total } \\
\hline & Lower & 2 & 3 & 4 & 5 & 6 & 7 & 8 & 9 & Upper & \\
\hline Average household size & 2,8 & 3,3 & 3,8 & 4,4 & 4,7 & 4,9 & 4,6 & 4,4 & 3,8 & 3,6 & 3,8 \\
\hline Main expenditure group & \multicolumn{11}{|c|}{ Rand per household per year } \\
\hline Food and non-alcoholic beverages & 3735 & 4638 & 5190 & 6108 & 6600 & 7392 & 7904 & 9225 & 11990 & 18267 & 8105 \\
\hline Alcoholic beverages and tobacco & 241 & 300 & 290 & 374 & 417 & 583 & 689 & 773 & 1117 & 1689 & 647 \\
\hline Clothing and footwear & 928 & 1122 & 1392 & 1684 & 1875 & 2161 & 2704 & 3419 & 4793 & 7725 & 2781 \\
\hline Housing, water, electricity, gas and other fuels & 2156 & 2466 & 3190 & 3753 & 4175 & 5199 & 7110 & 12321 & 26634 & 65427 & 13245 \\
\hline $\begin{array}{l}\text { Furnishings, household equipment and routine maintenance of } \\
\text { the dwelling }\end{array}$ & 706 & 1008 & 1375 & 1701 & 1778 & 2372 & 2794 & 4008 & 6398 & 16533 & 3868 \\
\hline Health & 151 & 233 & 271 & 322 & 409 & 482 & 500 & 863 & 1717 & 4377 & 933 \\
\hline Transport & 1195 & 1725 & 1835 & 2230 & 2597 & 3751 & 5085 & 9015 & 24690 & 59658 & 11180 \\
\hline Communication & 341 & 406 & 551 & 652 & 801 & 949 & 1397 & 2048 & 3875 & 8671 & 1969 \\
\hline Recreation and culture & 250 & 310 & 515 & 630 & 813 & 1114 & 1488 & 2114 & 4603 & 13977 & 2582 \\
\hline Education & 247 & 265 & 302 & 414 & 444 & 473 & 841 & 2142 & 2935 & 5496 & 1356 \\
\hline Restaurants and hotels & 479 & 321 & 372 & 423 & 513 & 774 & 932 & 1102 & 2304 & 5103 & 1232 \\
\hline Miscellaneous goods and services & 929 & 1159 & 1466 & 2207 & 2341 & 3038 & 4101 & 7851 & 16659 & 41050 & 8081 \\
\hline Other unclassified expenses & 23 & 27 & 37 & 49 & 56 & 87 & 109 & 174 & 310 & 850 & 172 \\
\hline Total & 11381 & 13982 & 16784 & 20547 & 22819 & 28374 & 35654 & 55055 & 108024 & 248823 & 56152 \\
\hline
\end{tabular}

Due to rounding, figures do not necessarily add up to totals 


\section{Expenditure}

Table 2.32 - Average household consumption expenditure by secondary expenditure group and income deciles

\begin{tabular}{|c|c|c|c|c|c|c|c|c|c|c|c|}
\hline & \multicolumn{10}{|c|}{ Income deciles } & \multirow[t]{2}{*}{ Total } \\
\hline & Lower & 2 & 3 & 4 & 5 & 6 & 7 & 8 & 9 & Upper & \\
\hline Average household size & 2,8 & 3,3 & 3,8 & 4,4 & 4,7 & 4,9 & 4,6 & 4,4 & 3,8 & 3,6 & 3,8 \\
\hline Secondary expenditure group & \multicolumn{11}{|c|}{ Rand per household per year } \\
\hline Food and non-alcoholic beverages & 3735 & 4638 & 5190 & 6108 & 6600 & 7392 & 7904 & 9225 & 11990 & 18267 & 8105 \\
\hline Food & 3439 & 4272 & 4740 & 5553 & 5955 & 6533 & 6896 & 7823 & 9750 & 13235 & 6820 \\
\hline Non-alcoholic beverages & 205 & 256 & 300 & 361 & 421 & 513 & 574 & 706 & 999 & 1634 & 597 \\
\hline Unspecified food & 91 & 110 & 149 & 194 & 224 & 346 & 434 & 696 & 1240 & 3398 & 688 \\
\hline Alcoholic beverages and tobacco & 241 & 300 & 290 & 374 & 417 & 583 & 689 & 773 & 1117 & 1689 & 647 \\
\hline Alcoholic beverages & 100 & 101 & 97 & 163 & 172 & 275 & 261 & 264 & 463 & 811 & 271 \\
\hline Tobacco & 141 & 199 & 193 & 211 & 245 & 309 & 428 & 510 & 654 & 878 & 377 \\
\hline Clothing and footwear & 928 & 1122 & 1392 & 1684 & 1875 & 2161 & 2704 & 3419 & 4793 & 7725 & 2781 \\
\hline Clothing & 629 & 773 & 965 & 1163 & 1291 & 1492 & 1906 & 2438 & 3489 & 5509 & 1966 \\
\hline Footwear & 300 & 348 & 428 & 522 & 584 & 669 & 798 & 981 & 1304 & 2216 & 815 \\
\hline Housing, water, electricity, gas and other fuels & 2156 & 2466 & 3190 & 3753 & 4175 & 5199 & 7110 & 12321 & 26634 & 65427 & 13245 \\
\hline Actual rentals for housing & 689 & 508 & 624 & 634 & 978 & 1129 & 1982 & 2873 & 6436 & 4313 & 2017 \\
\hline Imputed rentals for housing & 543 & 784 & 1141 & 1428 & 1460 & 1952 & 2656 & 5323 & 12888 & 42622 & 7081 \\
\hline Maintenance and repair of the dwelling & 43 & 95 & 109 & 185 & 134 & 213 & 334 & 484 & 1283 & 6896 & 978 \\
\hline Water supply and miscellaneous services relating to the dwelling & 274 & 269 & 391 & 493 & 541 & 823 & 953 & 2098 & 3715 & 8416 & 1798 \\
\hline Electricity, gas and other fuels & 606 & 809 & 924 & 1012 & 1062 & 1082 & 1185 & 1544 & 2311 & 3179 & 1371 \\
\hline
\end{tabular}




\begin{tabular}{|c|c|c|c|c|c|c|c|c|c|c|c|}
\hline & \multicolumn{10}{|c|}{ Income deciles } & \multirow[t]{2}{*}{ Total } \\
\hline & Lower & 2 & 3 & 4 & 5 & 6 & 7 & 8 & 9 & Upper & \\
\hline $\begin{array}{l}\text { Furnishings, household equipment and routine maintenance of } \\
\text { the dwelling }\end{array}$ & 706 & 1008 & 1375 & 1701 & 1778 & 2372 & 2794 & 4008 & 6398 & 16533 & 3868 \\
\hline Furniture and furnishings, carpets and other floor covering & 96 & 170 & 288 & 404 & 363 & 561 & 763 & 989 & 1448 & 3057 & 814 \\
\hline Household textiles & 190 & 290 & 409 & 464 & 510 & 629 & 703 & 991 & 1180 & 1754 & 712 \\
\hline Household appliances & 123 & 179 & 256 & 329 & 350 & 526 & 534 & 775 & 911 & 1517 & 550 \\
\hline Glassware, tableware and household utensils & 28 & 42 & 55 & 63 & 65 & 81 & 91 & 116 & 177 & 360 & 108 \\
\hline Tools and equipment for house and garden & 17 & 20 & 24 & 25 & 22 & 32 & 27 & 62 & 103 & 340 & 67 \\
\hline Goods and services for routine household maintenance & 252 & 307 & 343 & 415 & 469 & 542 & 676 & 1076 & 2579 & 9506 & 1617 \\
\hline Health & 151 & 233 & 271 & 322 & 409 & 482 & 500 & 863 & 1717 & 4377 & 933 \\
\hline Medical products, appliances and equipment & 60 & 88 & 92 & 117 & 137 & 150 & 188 & 327 & 691 & 1657 & 351 \\
\hline Out-patient services & 84 & 141 & 175 & 196 & 228 & 307 & 285 & 416 & 728 & 2213 & 477 \\
\hline Hospital services & 7 & 5 & 4 & 9 & 45 & 26 & 27 & 121 & 297 & 507 & 105 \\
\hline Transport & 1195 & 1725 & 1835 & 2230 & 2597 & 3751 & 5085 & 9015 & 24690 & 59658 & 11180 \\
\hline Purchase of vehicles & 285 & 580 & 518 & 460 & 475 & 970 & 1054 & 3447 & 14340 & 42244 & 6439 \\
\hline Operation of personal transport equipment & 141 & 118 & 138 & 237 & 349 & 756 & 1287 & 2720 & 7776 & 14763 & 2829 \\
\hline Transport services & 769 & 1025 & 1177 & 1533 & 1772 & 2022 & 2742 & 2847 & 2573 & 2621 & 1908 \\
\hline Operational values of other modes of transport & & 3 & 2 & 1 & 1 & 2 & 2 & 1 & 1 & 30 & 4 \\
\hline Communication & 341 & 406 & 551 & 652 & 801 & 949 & 1397 & 2048 & 3875 & 8671 & 1969 \\
\hline Postal services & 4 & 3 & 4 & 9 & 10 & 9 & 18 & 39 & 72 & 158 & 33 \\
\hline Telephone and telefax equipment & 85 & 95 & 119 & 146 & 183 & 203 & 247 & 322 & 467 & 480 & 235 \\
\hline Telephone and telefax services & 252 & 308 & 427 & 498 & 609 & 737 & 1132 & 1687 & 3336 & 8033 & 1702 \\
\hline Recreation and culture & 250 & 310 & 515 & 630 & 813 & 1114 & 1488 & 2114 & 4603 & 13977 & 2582 \\
\hline Audio-visual, photographic and information processing equipment & 115 & 137 & 253 & 316 & 341 & 512 & 734 & 863 & 1542 & 3489 & 830 \\
\hline Other major durables for recreation and culture & 3 & 4 & 37 & 7 & 8 & 14 & 18 & 44 & 49 & 269 & 45 \\
\hline Other recreational items and equipment, garden and pets & 16 & 19 & 29 & 44 & 49 & 77 & 106 & 218 & 858 & 3154 & 457 \\
\hline Recreational and cultural services & 54 & 73 & 93 & 118 & 167 & 240 & 305 & 486 & 1162 & 4408 & 711 \\
\hline Newspapers, books and stationery & 63 & 76 & 102 & 128 & 213 & 261 & 299 & 449 & 855 & 1862 & 431 \\
\hline Package holidays & t & - & 1 & 16 & 36 & 10 & 26 & 54 & 137 & 795 & 107 \\
\hline
\end{tabular}




\begin{tabular}{|c|c|c|c|c|c|c|c|c|c|c|c|}
\hline & \multicolumn{10}{|c|}{ Income deciles } & \multirow[t]{2}{*}{ Total } \\
\hline & Lower & 2 & 3 & 4 & 5 & 6 & 7 & 8 & 9 & Upper & \\
\hline Education & 247 & 265 & 302 & 414 & 444 & 473 & 841 & 2142 & 2935 & 5496 & 1356 \\
\hline Pre-primary and primary education & 55 & 65 & 75 & 125 & 107 & 122 & 195 & 404 & 710 & 1547 & 341 \\
\hline Secondary education & 50 & 68 & 76 & 94 & 108 & 133 & 188 & 268 & 611 & 1995 & 359 \\
\hline Tertiary education & 136 & 125 & 139 & 183 & 213 & 205 & 359 & 516 & 1530 & 1795 & 520 \\
\hline Education not definable by level & 5 & 7 & 12 & 11 & 15 & 13 & 100 & 955 & 84 & 159 & 136 \\
\hline Restaurants and hotels & 479 & 321 & 372 & 423 & 513 & 774 & 932 & 1102 & 2304 & 5103 & 1232 \\
\hline Catering services & 432 & 275 & 338 & 351 & 454 & 654 & 740 & 845 & 1325 & 2317 & 773 \\
\hline Accommodation services & 47 & 46 & 33 & 72 & 59 & 119 & 192 & 257 & 979 & 2786 & 459 \\
\hline Miscellaneous goods and services & 929 & 1159 & 1466 & 2207 & 2341 & 3038 & 4101 & 7851 & 16659 & 41050 & 8081 \\
\hline Personal care & 224 & 275 & 292 & 375 & 394 & 499 & 603 & 775 & 1179 & 2339 & 696 \\
\hline Personal effects & 45 & 48 & 65 & 75 & 113 & 113 & 166 & 240 & 491 & 1192 & 255 \\
\hline Social protection & 11 & 15 & 23 & 48 & 55 & 66 & 55 & 158 & 249 & 534 & 121 \\
\hline Insurance & 175 & 269 & 339 & 451 & 515 & 770 & 1337 & 3878 & 9762 & 27894 & 4540 \\
\hline Financial services n.e.c. & 88 & 76 & 139 & 302 & 234 & 355 & 495 & 774 & 1815 & 3622 & 790 \\
\hline Other services n.e.c. & 387 & 476 & 607 & 956 & 1030 & 1234 & 1445 & 2027 & 3162 & 5469 & 1680 \\
\hline Other unclassified expenses & 23 & 27 & 37 & 49 & 56 & 87 & 109 & 174 & 310 & 850 & 172 \\
\hline Total & 11381 & 13982 & 16784 & 20547 & 22819 & 28374 & 35654 & 55055 & 108024 & 248823 & 56152 \\
\hline
\end{tabular}

Due to rounding, figures do not necessarily add up to totals 


\section{Expenditure}

Table 2.33 - Average household consumption expenditure by third expenditure group and income deciles

\begin{tabular}{|c|c|c|c|c|c|c|c|c|c|c|c|}
\hline & \multicolumn{10}{|c|}{ Income deciles } & \multirow[t]{2}{*}{ Total } \\
\hline & Lower & 2 & 3 & 4 & 5 & 6 & 7 & 8 & 9 & Upper & \\
\hline Average household size & 2,8 & 3,3 & 3,8 & 4,4 & 4,7 & 4,9 & 4,6 & 4,4 & 3,8 & 3,6 & 3,8 \\
\hline Third expenditure group & \multicolumn{11}{|c|}{ Rand per household per year } \\
\hline Food and non-alcoholic beverages & 3735 & 4638 & 5190 & 6108 & 6600 & 7392 & 7904 & 9225 & 11990 & 18267 & 8105 \\
\hline Bread and cereals & 1106 & 1398 & 1550 & 1727 & 1737 & 1805 & 1801 & 1844 & 1878 & 2039 & 1688 \\
\hline Meat & 781 & 991 & 1175 & 1448 & 1719 & 1991 & 2215 & 2594 & 3285 & 4193 & 2039 \\
\hline Fish & 129 & 127 & 144 & 212 & 204 & 244 & 238 & 286 & 497 & 750 & 283 \\
\hline Milk, cheese and eggs & 321 & 382 & 418 & 509 & 559 & 648 & 752 & 934 & 1359 & 1886 & 777 \\
\hline Oils and fats & 155 & 193 & 203 & 249 & 245 & 254 & 275 & 299 & 318 & 437 & 263 \\
\hline Fruits & 57 & 78 & 99 & 108 & 124 & 137 & 167 & 216 & 352 & 728 & 207 \\
\hline Vegetables & 462 & 583 & 581 & 648 & 655 & 711 & 696 & 807 & 1003 & 1564 & 771 \\
\hline Sugar, jam, honey, chocolate and confectionery & 220 & 275 & 314 & 361 & 352 & 385 & 385 & 400 & 529 & 840 & 406 \\
\hline Food products n.e.c. & 207 & 246 & 257 & 292 & 360 & 358 & 367 & 444 & 529 & 797 & 386 \\
\hline Coffee, tea and cocoa & 67 & 85 & 98 & 108 & 131 & 132 & 145 & 144 & 214 & 356 & 148 \\
\hline Mineral waters, soft drinks, fruit and vegetable juices & 138 & 171 & 202 & 253 & 289 & 380 & 429 & 562 & 785 & 1277 & 449 \\
\hline Unspecified food & 91 & 110 & 149 & 194 & 224 & 346 & 434 & 696 & 1240 & 3398 & 688 \\
\hline Alcoholic beverages and tobacco & 241 & 300 & 290 & 374 & 417 & 583 & 689 & 773 & 1117 & 1689 & 647 \\
\hline Spirits & 15 & 24 & 24 & 25 & 19 & 97 & 54 & 60 & 102 & 302 & 72 \\
\hline Wine & 9 & 12 & 10 & 21 & 18 & 21 & 28 & 34 & 108 & 279 & 54 \\
\hline Beer & 76 & 66 & 64 & 117 & 135 & 157 & 179 & 169 & 253 & 230 & 145 \\
\hline Tobacco & 141 & 199 & 193 & 211 & 245 & 309 & 428 & 510 & 654 & 878 & 377 \\
\hline
\end{tabular}




\begin{tabular}{|c|c|c|c|c|c|c|c|c|c|c|c|}
\hline & \multicolumn{10}{|c|}{ Income deciles } & \multirow[t]{2}{*}{ Total } \\
\hline & Lower & 2 & 3 & 4 & 5 & 6 & 7 & 8 & 9 & Upper & \\
\hline Clothing and footwear & 928 & 1122 & 1392 & 1684 & 1875 & 2161 & 2704 & 3419 & 4793 & 7725 & 2781 \\
\hline Clothing materials & 4 & 4 & 11 & 17 & 9 & 12 & 18 & 26 & 51 & 44 & 20 \\
\hline Garments & 606 & 751 & 933 & 1119 & 1250 & 1433 & 1834 & 2352 & 3341 & 5275 & 1889 \\
\hline Other articles of clothing and clothing accessories & 15 & 16 & 18 & 21 & 26 & 38 & 38 & 51 & 82 & 156 & 46 \\
\hline Cleaning, repair and hire of clothing & 4 & 2 & 3 & 5 & 6 & 8 & 16 & 10 & 14 & 33 & 10 \\
\hline Shoes and other footwear & 296 & 345 & 425 & 517 & 579 & 662 & 790 & 974 & 1296 & 2208 & 809 \\
\hline Repair and hire of footwear & 4 & 3 & 3 & 5 & 5 & 6 & 8 & 7 & 8 & 8 & 6 \\
\hline Housing, water, electricity, gas and other fuels & 2156 & 2466 & 3190 & 3753 & 4175 & 5199 & 7110 & 12321 & 26634 & 65427 & 13245 \\
\hline Actual rentals paid by tenants & 689 & 508 & 624 & 634 & 978 & 1129 & 1982 & 2873 & 6436 & 4313 & 2017 \\
\hline Imputed rentals of owner-occupiers & 543 & 784 & 1141 & 1428 & 1460 & 1952 & 2656 & 5323 & 12888 & 42622 & 7081 \\
\hline Materials for maintenance and repair of the dwelling & 18 & 39 & 44 & 97 & 64 & 102 & 101 & 216 & 443 & 2574 & 370 \\
\hline Service of the maintenance and repair of the dwelling & 25 & 56 & 65 & 88 & 70 & 111 & 233 & 267 & 841 & 4323 & 608 \\
\hline Water and electricity & 68 & 47 & 56 & 83 & 147 & 296 & 218 & 652 & 1022 & 2712 & 530 \\
\hline Water supply & 64 & 84 & 129 & 170 & 159 & 191 & 219 & 464 & 890 & 1184 & 356 \\
\hline Refuse collection & 37 & 41 & 51 & 50 & 60 & 78 & 105 & 163 & 195 & 325 & 110 \\
\hline Sewerage collection & 32 & 34 & 41 & 43 & 48 & 67 & 89 & 167 & 357 & 387 & 126 \\
\hline Other services relating to the dwelling & 72 & 63 & 114 & 148 & 127 & 191 & 322 & 651 & 1252 & 3809 & 675 \\
\hline Electricity & 279 & 355 & 470 & 512 & 653 & 674 & 878 & 1323 & 2109 & 2989 & 1024 \\
\hline Gas & 10 & 12 & 18 & 23 & 24 & 37 & 25 & 39 & 82 & 89 & 36 \\
\hline Liquid fuels & 185 & 215 & 206 & 238 & 208 & 198 & 161 & 123 & 78 & 33 & 165 \\
\hline Solid fuels & 132 & 228 & 230 & 239 & 176 & 174 & 121 & 60 & 41 & 68 & 147 \\
\hline $\begin{array}{l}\text { Furnishings, household equipment and routine maintenance } \\
\text { of the dwelling }\end{array}$ & 706 & 1008 & 1375 & 1701 & 1778 & 2372 & 2794 & 4008 & 6398 & 16533 & 3868 \\
\hline Furniture and furnishings & 89 & 160 & 271 & 372 & 341 & 515 & 709 & 892 & 1225 & 2511 & 709 \\
\hline Carpets and other floor covering & 6 & 9 & 15 & 23 & 18 & 37 & 47 & 81 & 142 & 461 & 84 \\
\hline Repair of furniture, furnishings and floor covering & 1 & 2 & 2 & 9 & 3 & 9 & 7 & 16 & 81 & 85 & 22 \\
\hline Household textiles & 190 & 290 & 409 & 464 & 510 & 629 & 703 & 991 & 1180 & 1754 & 712 \\
\hline Major household appliances & 97 & 142 & 220 & 284 & 291 & 461 & 453 & 658 & 757 & 1188 & 455 \\
\hline Small electrical household appliances & 24 & 32 & 31 & 40 & 47 & 54 & 68 & 101 & 116 & 247 & 76 \\
\hline
\end{tabular}




\begin{tabular}{|c|c|c|c|c|c|c|c|c|c|c|c|}
\hline & \multicolumn{10}{|c|}{ Income deciles } & \multirow[t]{2}{*}{ Total } \\
\hline & Lower & 2 & 3 & 4 & 5 & 6 & 7 & 8 & 9 & Upper & \\
\hline Repair of household appliances & 2 & 5 & 5 & 6 & 12 & 11 & 13 & 16 & 38 & 82 & 19 \\
\hline Glassware, tableware and household utensils & 28 & 42 & 55 & 63 & 65 & 81 & 91 & 116 & 177 & 360 & 108 \\
\hline Major tools and equipment & 2 & & 1 & 1 & 2 & 3 & 3 & 17 & 41 & 144 & 21 \\
\hline Small tools and miscellaneous accessories & 15 & 19 & 23 & 25 & 19 & 29 & 25 & 45 & 62 & 196 & 46 \\
\hline Non-durable household goods & 220 & 268 & 302 & 335 & 349 & 404 & 428 & 500 & 657 & 1166 & 463 \\
\hline Domestic services and household arcticles & 32 & 39 & 42 & 81 & 120 & 139 & 247 & 576 & 1921 & 8340 & 1154 \\
\hline Health & 151 & 233 & 271 & 322 & 409 & 482 & 500 & 863 & 1717 & 4377 & 933 \\
\hline Pharmaceutical products & 56 & 81 & 88 & 100 & 132 & 139 & 173 & 292 & 610 & 1463 & 314 \\
\hline Other medical products & 3 & 4 & 3 & 5 & 4 & 7 & 9 & 13 & 11 & 51 & 11 \\
\hline Therapeutic appliances and equipment & 1 & 2 & 1 & 12 & 1 & 4 & 6 & 22 & 70 & 143 & 26 \\
\hline Medical services & 79 & 133 & 161 & 180 & 205 & 238 & 249 & 346 & 549 & 1476 & 362 \\
\hline Dental services & 2 & 3 & 3 & 5 & 12 & 7 & 12 & 35 & 104 & 355 & 54 \\
\hline Paramedic services & 3 & 5 & 11 & 10 & 10 & 62 & 25 & 34 & 75 & 383 & 62 \\
\hline Hospital services & 7 & 5 & 4 & 9 & 45 & 26 & 27 & 121 & 297 & 507 & 105 \\
\hline Transport & 1195 & 1725 & 1835 & 2230 & 2597 & 3751 & 5085 & 9015 & 24690 & 59658 & 11180 \\
\hline Motor cars & 281 & 577 & 514 & 436 & 466 & 965 & 1051 & 3435 & 14113 & 41976 & 6383 \\
\hline Motorcycles & - & - & - & - & 4 & 2 & - & 7 & 197 & 164 & 37 \\
\hline Bicycles & 1 & 1 & 2 & 23 & 2 & 1 & 1 & 4 & 30 & 56 & 12 \\
\hline Animal-drawn vehicles & 2 & 2 & 2 & 1 & 3 & 2 & 1 & 1 & - & 48 & 6 \\
\hline Spare parts and accessories & 12 & 17 & 19 & 42 & 51 & 115 & 164 & 349 & 1022 & 1595 & 339 \\
\hline Fuels and lubricants & 96 & 61 & 80 & 131 & 155 & 474 & 869 & 1844 & 5381 & 10293 & 1939 \\
\hline Maintenance and repair of personal transport equipment & 11 & 5 & 4 & 11 & 23 & 56 & 92 & 221 & 659 & 1519 & 260 \\
\hline Other services in respect of personal transport equipment & 21 & 34 & 36 & 52 & 120 & 111 & 163 & 306 & 714 & 1356 & 291 \\
\hline Passenger transport by rail & 54 & 68 & 50 & 55 & 123 & 113 & 163 & 107 & 60 & 46 & 84 \\
\hline Passenger transport by road & 712 & 944 & 1118 & 1464 & 1634 & 1887 & 2551 & 2649 & 2206 & 1290 & 1646 \\
\hline Passenger transport by air & - & 3 & 2 & 7 & 9 & 6 & 7 & 74 & 278 & 1204 & 159 \\
\hline
\end{tabular}




\begin{tabular}{|c|c|c|c|c|c|c|c|c|c|c|c|}
\hline & \multicolumn{10}{|c|}{ Income deciles } & \multirow[t]{2}{*}{ Total } \\
\hline & Lower & 2 & 3 & 4 & 5 & 6 & 7 & 8 & 9 & Upper & \\
\hline Passenger transport by sea and inland waterway & - & - & - & - & - & - & - & 1 & - & 11 & 1 \\
\hline Other puchased transport services & 3 & 10 & 6 & 7 & 8 & 17 & 21 & 16 & 29 & 69 & 19 \\
\hline Cost for other modes of transport & & 3 & 2 & 1 & 1 & 2 & 2 & 1 & 1 & 30 & 4 \\
\hline Communication & 341 & 406 & 551 & 652 & 801 & 949 & 1397 & 2048 & 3875 & 8671 & 1969 \\
\hline Postal services & 4 & 3 & 4 & 9 & 10 & 9 & 18 & 39 & 72 & 158 & 33 \\
\hline Telephone and telefax equipment & 85 & 95 & 119 & 146 & 183 & 203 & 247 & 322 & 467 & 480 & 235 \\
\hline Telephone and telefax services & 252 & 308 & 427 & 498 & 609 & 737 & 1132 & 1687 & 3336 & 8033 & 1702 \\
\hline Recreation and culture & 250 & 310 & 515 & 630 & 813 & 1114 & 1488 & 2114 & 4603 & 13977 & 2582 \\
\hline $\begin{array}{l}\text { Equipment for the reception, recording and reproduction of sound } \\
\text { and pictures }\end{array}$ & 81 & 116 & 223 & 285 & 274 & 386 & 567 & 579 & 677 & 1014 & 420 \\
\hline $\begin{array}{l}\text { Photographic and cinematographic equipment and optical } \\
\text { instruments }\end{array}$ & 1 & 5 & & 1 & 3 & 23 & 18 & 31 & 93 & 432 & 61 \\
\hline Information processing equipment & 25 & 6 & 12 & 8 & 31 & 57 & 68 & 145 & 527 & 1493 & 237 \\
\hline Recording media & 8 & 11 & 17 & 21 & 33 & 46 & 81 & 108 & 245 & 551 & 112 \\
\hline Major durables for outdoor recreation & - & - & - & - & - & - & 2 & 5 & 5 & 175 & 19 \\
\hline Musical instruments and major durables for outdoor recreation & - & - & 33 & 2 & 1 & 7 & 6 & 30 & 25 & 62 & 17 \\
\hline $\begin{array}{l}\text { Maintenance and repair of other major durables for recreation and } \\
\text { culture }\end{array}$ & & 4 & 4 & 5 & 7 & 7 & 10 & 10 & 19 & 32 & 10 \\
\hline Games, toys and hobbies & 2 & 2 & 3 & 5 & 6 & 10 & 10 & 30 & 181 & 434 & 68 \\
\hline Equipment for sport, camping and open-air recreation & 4 & 2 & 3 & 8 & 4 & 12 & 14 & 15 & 100 & 659 & 82 \\
\hline Gardens, plants and flowers & 2 & 4 & 5 & 6 & 11 & 12 & 13 & 45 & 132 & 671 & 90 \\
\hline Pets and related products & 8 & 10 & 18 & 25 & 26 & 41 & 66 & 117 & 390 & 1035 & 174 \\
\hline Veterinary and other services & - & - & - & - & 1 & 2 & 2 & 11 & 56 & 356 & 43 \\
\hline Recreational and sporting services & 9 & 11 & 9 & 14 & 35 & 49 & 51 & 75 & 213 & 1117 & 158 \\
\hline Cultural services & 21 & 22 & 24 & 39 & 49 & 67 & 105 & 223 & 613 & 2265 & 343 \\
\hline Games of chance & 23 & 40 & 61 & 65 & 83 & 124 & 150 & 188 & 336 & 1026 & 209 \\
\hline Books & 11 & 17 & 19 & 22 & 35 & 42 & 55 & 108 & 238 & 531 & 108 \\
\hline Newspaper and periodicals & 25 & 25 & 46 & 51 & 114 & 149 & 180 & 245 & 435 & 1022 & 229 \\
\hline Miscellaneous printed matter & & & & 2 & 1 & 2 & 4 & 7 & 16 & 52 & 8 \\
\hline Stationery and drawing materials & 27 & 34 & 37 & 53 & 63 & 68 & 60 & 90 & 167 & 257 & 85 \\
\hline Package holidays & -1 & -1 & 1 & 16 & 36 & 10 & 26 & 54 & 137 & 795 & 107 \\
\hline
\end{tabular}




\begin{tabular}{|c|c|c|c|c|c|c|c|c|c|c|c|}
\hline & \multicolumn{10}{|c|}{ Income deciles } & \multirow[t]{2}{*}{ Total } \\
\hline & Lower & 2 & 3 & 4 & 5 & 6 & 7 & 8 & 9 & Upper & \\
\hline Education & 247 & 265 & 302 & 414 & 444 & 473 & 841 & 2142 & 2935 & 5496 & 1356 \\
\hline Pre-primary and primary education & 55 & 65 & 75 & 125 & 107 & 122 & 195 & 404 & 710 & 1547 & 341 \\
\hline Secondary education & 50 & 68 & 76 & 94 & 108 & 133 & 188 & 268 & 611 & 1995 & 359 \\
\hline Tertiary education & 136 & 125 & 139 & 183 & 213 & 205 & 359 & 516 & 1530 & 1795 & 520 \\
\hline Education not definable by level & 5 & 7 & 12 & 11 & 15 & 13 & 100 & 955 & 84 & 159 & 136 \\
\hline Restaurants and hotels & 479 & 321 & 372 & 423 & 513 & 774 & 932 & 1102 & 2304 & 5103 & 1232 \\
\hline Beverages in restaurants, cafes, canteens and the like & 132 & 120 & 141 & 156 & 166 & 251 & 287 & 261 & 224 & 290 & 203 \\
\hline Meals in restaurants, cafes, canteens and the like & 300 & 155 & 198 & 195 & 288 & 404 & 453 & 584 & 1101 & 2027 & 571 \\
\hline Accommodation services & 47 & 46 & 33 & 72 & 59 & 119 & 192 & 257 & 979 & 2786 & 459 \\
\hline Miscellaneous goods and services & 929 & 1159 & 1466 & 2207 & 2341 & 3038 & 4101 & 7851 & 16659 & 41050 & 8081 \\
\hline Hairdressing salons and personal grooming establishment & 3 & 3 & 6 & 9 & 8 & 16 & 15 & 33 & 93 & 236 & 42 \\
\hline Electrical appliances for personal care & - & 1 & 1 & 2 & 3 & 5 & 4 & 5 & 9 & 27 & 6 \\
\hline Other appliances, articles and products for personal care & 221 & 272 & 286 & 364 & 383 & 478 & 584 & 736 & 1078 & 2077 & 648 \\
\hline Jewellery, clocks and watches & 17 & 15 & 24 & 24 & 55 & 48 & 86 & 116 & 258 & 745 & 139 \\
\hline Other personal effects & 28 & 33 & 41 & 51 & 58 & 65 & 80 & 123 & 233 & 447 & 116 \\
\hline Social protection services & 11 & 15 & 23 & 48 & 55 & 66 & 55 & 158 & 249 & 534 & 121 \\
\hline Insurance connected with the dwelling & 6 & 11 & 21 & 40 & 29 & 79 & 194 & 855 & 2395 & 11835 & 1547 \\
\hline Insurance connected with health & 39 & 39 & 20 & 24 & 55 & 131 & 461 & 1798 & 4927 & 11637 & 1914 \\
\hline Insurance connected with transport & 2 & & 1 & 8 & 6 & 24 & 51 & 236 & 1145 & 3217 & 469 \\
\hline Other insurance & 128 & 219 & 297 & 379 & 425 & 536 & 631 & 989 & 1295 & 1205 & 610 \\
\hline Financial services n.e.c. & 88 & 76 & 139 & 302 & 234 & 355 & 495 & 774 & 1815 & 3622 & 790 \\
\hline Other services & 387 & 476 & 607 & 956 & 1030 & 1234 & 1445 & 2027 & 3162 & 5469 & 1680 \\
\hline Other unclassified expenses & 23 & 27 & 37 & 49 & 56 & 87 & 109 & 174 & 310 & 850 & 172 \\
\hline Total & 11381 & 13982 & 16784 & 20547 & 22819 & 28374 & 35654 & 55055 & 108024 & 248823 & 56152 \\
\hline
\end{tabular}




\section{Expenditure}

Table 2.34 - Average household consumption expenditure by main expenditure group and province

\begin{tabular}{|c|c|c|c|c|c|c|c|c|c|c|}
\hline & \begin{tabular}{r|} 
Western \\
Cape
\end{tabular} & \begin{tabular}{r|} 
Eastern \\
Cape
\end{tabular} & $\begin{array}{r}\text { Northern } \\
\text { Cape }\end{array}$ & \begin{tabular}{l|} 
Free \\
State
\end{tabular} & $\begin{array}{r}\text { KwaZulu- } \\
\text { Natal }\end{array}$ & \begin{tabular}{l|} 
North \\
West
\end{tabular} & Gauteng & Mpumalanga & Limpopo & Total \\
\hline $\begin{array}{l}\text { Number of households in sample } \\
\text { Number of households in population }\end{array}$ & $\begin{array}{r}2404 \\
1271541 \\
\end{array}$ & $\begin{array}{r}2825 \\
1723789 \\
\end{array}$ & $\begin{array}{r}1726 \\
293306 \\
\end{array}$ & $\begin{array}{r}1754 \\
899152 \\
\end{array}$ & $\begin{array}{r}4732 \\
2214405 \\
\end{array}$ & $\begin{array}{r}1569 \\
907475 \\
\end{array}$ & $\begin{array}{r}2496 \\
2967693 \\
\end{array}$ & $\begin{array}{r}1687 \\
879707 \\
\end{array}$ & $\begin{array}{r}1951 \\
1300512 \\
\end{array}$ & $\begin{array}{r}21144 \\
12457580 \\
\end{array}$ \\
\hline Main expenditure group & \multicolumn{10}{|c|}{ Rand per household per year } \\
\hline Food and non-alcoholic beverages & 12960 & 6957 & 6173 & 6527 & 7529 & 6549 & 9334 & 7019 & 6406 & 8105 \\
\hline Alcoholic beverages and tobacco & 1381 & 532 & 680 & 549 & 417 & 541 & 860 & 408 & 287 & 647 \\
\hline Clothing and footwear & 3597 & 2213 & 2232 & 2905 & 2480 & 2302 & 3621 & 2427 & 1940 & 2781 \\
\hline Housing, water, electricity, gas and other fuels & 29496 & 8379 & 7855 & 9957 & 10165 & 8679 & 19284 & 7573 & 5783 & 13245 \\
\hline $\begin{array}{l}\text { Furnishings, household equipment and routine } \\
\text { maintenance of the dwelling }\end{array}$ & 5351 & 2838 & 3291 & 4148 & 3208 & 3592 & 4933 & 3950 & 2547 & 3868 \\
\hline Health & 1454 & 612 & 626 & 1161 & 766 & 725 & 1366 & 610 & 419 & 933 \\
\hline Transport & 22090 & 7470 & 7290 & 10718 & 8207 & 7802 & 16035 & 9325 & 4224 & 11180 \\
\hline Communication & 3792 & 1282 & 1371 & 1805 & 1764 & 1626 & 2574 & 1441 & 912 & 1969 \\
\hline Recreation and culture & 5486 & 1317 & 1669 & 2277 & 2050 & 1749 & 3801 & 1849 & 1033 & 2582 \\
\hline Education & 1942 & 799 & 466 & 1272 & 1179 & 1625 & 1885 & 1019 & 916 & 1356 \\
\hline Restaurants and hotels & 2351 & 720 & 1037 & 1254 & 726 & 833 & 1877 & 727 & 859 & 1232 \\
\hline Miscellaneous goods and services & 12439 & 5949 & 5651 & 7540 & 5965 & 7723 & 11954 & 6623 & 3573 & 8081 \\
\hline Other unclassified expenses & 636 & 74 & 47 & 67 & 156 & 38 & 175 & 55 & 143 & 172 \\
\hline Total & 102977 & 39141 & 38389 & 50181 & 44612 & 43784 & 77700 & 43026 & 29042 & 56152 \\
\hline
\end{tabular}

Due to rounding, figures do not necessarily add up to totals 


\section{Expenditure}

Table 2.35 - Average household consumption expenditure by secondary expenditure group and province

\begin{tabular}{|c|c|c|c|c|c|c|c|c|c|c|}
\hline & \begin{tabular}{r|} 
Western \\
Cape
\end{tabular} & \begin{tabular}{r|} 
Eastern \\
Cape
\end{tabular} & $\begin{array}{r}\text { Northern } \\
\text { Cape }\end{array}$ & Free State & $\begin{array}{r}\text { KwaZulu- } \\
\text { Natal }\end{array}$ & North West & Gauteng & Mpumalanga & Limpopo & Total \\
\hline Number of households in sample & 2404 & 2825 & 1726 & 1754 & 4732 & 1569 & 2496 & 1687 & 1951 & 21144 \\
\hline Number of households in population & 1271541 & 1723789 & 293306 & 899152 & 2214405 & 907475 & 2967693 & 879707 & 1300512 & 12457580 \\
\hline Secondary expenditure group & \multicolumn{10}{|c|}{ Rand per household per year } \\
\hline Food & 9469 & 6232 & 5514 & 5746 & 6486 & 5869 & 7785 & 6287 & 5438 & 6820 \\
\hline Non-alcoholic beverages & 948 & 429 & 469 & 512 & 421 & 528 & 847 & 514 & 396 & 597 \\
\hline Unspecified food & 2544 & 296 & 190 & 269 & 623 & 152 & 701 & 218 & 572 & 688 \\
\hline Alcoholic beverages & 544 & 210 & 176 & 173 & 181 & 241 & 399 & 153 & 133 & 271 \\
\hline Tobacco & 837 & 321 & 504 & 376 & 236 & 300 & 461 & 255 & 154 & 377 \\
\hline Clothing & 2609 & 1548 & 1650 & 2031 & 1753 & 1648 & 2516 & 1740 & 1395 & 1966 \\
\hline Footwear & 989 & 664 & 582 & 873 & 727 & 653 & 1105 & 687 & 545 & 815 \\
\hline Actual rentals for housing & 4136 & 1094 & 1088 & 1450 & 1475 & 2448 & 2950 & 1088 & 892 & 2017 \\
\hline Imputed rentals for housing & 17688 & 4311 & 3318 & 4418 & 4952 & 3423 & 10758 & 3818 & 3065 & 7081 \\
\hline Maintenance and repair of the dwelling & 2961 & 853 & 573 & 676 & 534 & 423 & 1285 & 467 & 292 & 978 \\
\hline $\begin{array}{l}\text { Water supply and miscellaneous services relating to the } \\
\text { dwelling }\end{array}$ & 2553 & 830 & 1562 & 1807 & 1970 & 1030 & 3012 & 953 & 432 & 1798 \\
\hline Electricity, gas and other fuels & 2157 & 1290 & 1314 & 1606 & 1233 & 1355 & 1280 & 1246 & 1102 & 1371 \\
\hline $\begin{array}{l}\text { Furniture and furnishings, carpets and other floor } \\
\text { covering }\end{array}$ & 1071 & 615 & 680 & 941 & 659 & 707 & 998 & 929 & 608 & 814 \\
\hline Household textiles & 773 & 674 & 769 & 848 & 565 & 700 & 744 & 949 & 620 & 712 \\
\hline Household appliances & 790 & 427 & 657 & 592 & 510 & 470 & 585 & 609 & 430 & 550 \\
\hline Glassware, tableware and household utensils & 98 & 110 & 69 & 143 & 72 & 88 & 136 & 133 & 93 & 108 \\
\hline Tools and equipment for house and garden & 115 & 56 & 61 & 63 & 59 & 55 & 84 & 45 & 37 & 67 \\
\hline
\end{tabular}




\begin{tabular}{|c|c|c|c|c|c|c|c|c|c|c|}
\hline & $\begin{array}{r}\text { Western } \\
\text { Cape }\end{array}$ & \begin{tabular}{r|} 
Eastern \\
Cape
\end{tabular} & \begin{tabular}{r|} 
Northern \\
Cape
\end{tabular} & Free State & $\begin{array}{r}\text { KwaZulu- } \\
\text { Natal }\end{array}$ & North West & Gauteng & Mpumalanga & Limpopo & Total \\
\hline Goods and services for routine household maintenance & 2505 & 956 & 1054 & 1560 & 1342 & 1573 & 2385 & 1285 & 757 & 1617 \\
\hline Medical products, appliances and equipment & 638 & 267 & 233 & 509 & 275 & 305 & 432 & 232 & 153 & 351 \\
\hline Out-patient services & 691 & 311 & 258 & 432 & 414 & 366 & 742 & 350 & 236 & 477 \\
\hline Hospital services & 126 & 33 & 136 & 220 & 76 & 55 & 192 & 28 & 30 & 105 \\
\hline Purchase of vehicles & 15158 & 4150 & 4367 & 6427 & 4066 & 3710 & 9009 & 6133 & 1708 & 6439 \\
\hline Operation of personal transport equipment & 5188 & 1733 & 1970 & 2677 & 2235 & 2432 & 4179 & 1641 & 1287 & 2829 \\
\hline Transport services & 1739 & 1582 & 942 & 1600 & 1905 & 1658 & 2841 & 1552 & 1229 & 1908 \\
\hline Operational values of other modes of transport & 5 & 5 & 11 & 14 & 1 & 1 & 6 & 1 & - & 4 \\
\hline Postal services & 44 & 20 & 19 & 35 & 39 & 24 & 39 & 32 & 18 & 33 \\
\hline Telephone and telefax equipment & 268 & 219 & 192 & 251 & 214 & 189 & 252 & 275 & 221 & 235 \\
\hline Telephone and telefax services & 3480 & 1043 & 1160 & 1519 & 1511 & 1413 & 2283 & 1134 & 673 & 1702 \\
\hline $\begin{array}{l}\text { Audio-visual, photographic and information processing } \\
\text { equipment }\end{array}$ & 1544 & 515 & 730 & 828 & 685 & 640 & 1026 & 828 & 510 & 830 \\
\hline Other major durables for recreation and culture & 68 & 16 & 65 & 57 & 20 & 31 & 53 & 121 & 35 & 45 \\
\hline $\begin{array}{l}\text { Other recreational items and equipment, garden and } \\
\text { pets }\end{array}$ & 1289 & 206 & 239 & 366 & 309 & 312 & 672 & 222 & 113 & 457 \\
\hline Recreational and cultural services & 1614 & 280 & 399 & 617 & 455 & 453 & 1214 & 437 & 187 & 711 \\
\hline Newspapers, books and stationery & 781 & 277 & 229 & 341 & 353 & 297 & 681 & 238 & 185 & 431 \\
\hline Package holidays & 191 & 23 & 8 & 69 & 229 & 16 & 156 & 3 & 3 & 107 \\
\hline Pre-primary and primary education & 588 & 268 & 167 & 194 & 285 & 233 & 513 & 208 & 202 & 341 \\
\hline Secondary education & 486 & 213 & 117 & 230 & 327 & 256 & 515 & 507 & 245 & 359 \\
\hline Tertiary education & 774 & 229 & 168 & 496 & 538 & 1075 & 543 & 277 & 451 & 520 \\
\hline Education not definable by level & 95 & 88 & 14 & 352 & 30 & 61 & 315 & 27 & 18 & 136 \\
\hline Catering services & 1644 & 520 & 718 & 831 & 386 & 516 & 1093 & 397 & 593 & 773 \\
\hline Accommodation services & 707 & 200 & 319 & 423 & 341 & 317 & 784 & 330 & 265 & 459 \\
\hline
\end{tabular}




\begin{tabular}{|c|c|c|c|c|c|c|c|c|c|c|}
\hline & $\begin{array}{r}\text { Western } \\
\text { Cape }\end{array}$ & \begin{tabular}{r|} 
Eastern \\
Cape
\end{tabular} & $\begin{array}{r}\text { Northern } \\
\text { Cape }\end{array}$ & Free State & $\begin{array}{r}\text { KwaZulu- } \\
\text { Natal }\end{array}$ & North West & Gauteng & Mpumalanga & Limpopo & Total \\
\hline Personal care & 1286 & 405 & 583 & 630 & 437 & 562 & 1066 & 533 & 374 & 696 \\
\hline Personal effects & 424 & 155 & 135 & 286 & 259 & 167 & 343 & 163 & 143 & 255 \\
\hline Social protection & 245 & 86 & 45 & 94 & 32 & 95 & 225 & 90 & 41 & 121 \\
\hline Insurance & 7116 & 2993 & 3002 & 4252 & 2895 & 4161 & 7489 & 3649 & 1554 & 4540 \\
\hline Financial services n.e.c. & 1072 & 658 & 579 & 584 & 596 & 1439 & 948 & 876 & 339 & 790 \\
\hline Other services n.e.c. & 2296 & 1652 & 1305 & 1694 & 1747 & 1300 & 1883 & 1311 & 1123 & 1680 \\
\hline Other diary & 636 & 74 & 47 & 67 & 156 & 38 & 175 & 55 & 143 & 172 \\
\hline Total & 102977 & 39141 & 38389 & 50181 & 44612 & 43784 & 77700 & 43026 & 29042 & 56152 \\
\hline
\end{tabular}

Due to rounding figures do not necessarily add up to totals

- No expenditure 


\section{Expenditure}

Table 2.36 - Average household consumption expenditure by third expenditure group and province

\begin{tabular}{|c|c|c|c|c|c|c|c|c|c|c|}
\hline & $\begin{array}{r}\text { Western } \\
\text { Cape }\end{array}$ & $\begin{array}{r}\text { Eastern } \\
\text { Cape }\end{array}$ & $\begin{array}{r}\text { Northern } \\
\text { Cape }\end{array}$ & $\begin{array}{l}\text { Free } \\
\text { State }\end{array}$ & $\begin{array}{r}\text { KwaZulu- } \\
\text { Natal }\end{array}$ & North West & Gauteng & Mpumalanga & Limpopo & Total \\
\hline Number of households in sample & 2404 & 2825 & 1726 & 1754 & 4732 & 1569 & 2496 & 1687 & 1951 & 21144 \\
\hline Number of households in population & 1271541 & 1723789 & 293306 & 899152 & 2214405 & 907475 & 2967693 & 879707 & 1300512 & 12457580 \\
\hline Third expenditure group & \multicolumn{10}{|c|}{ Rand per household per year } \\
\hline Bread and cereals & 1682 & 1746 & 1069 & 1285 & 1901 & 1374 & 1653 & 1733 & 1946 & 1688 \\
\hline Meat & 3073 & 1562 & 2032 & 1800 & 1740 & 1801 & 2571 & 1856 & 1418 & 2039 \\
\hline Fish & 534 & 173 & 233 & 256 & 144 & 207 & 372 & 411 & 217 & 283 \\
\hline Milk, cheese and eggs & 1231 & 706 & 501 & 724 & 639 & 742 & 971 & 615 & 450 & 777 \\
\hline Oils and fats & 330 & 254 & 187 & 202 & 333 & 204 & 269 & 242 & 189 & 263 \\
\hline Fruits & 370 & 152 & 119 & 178 & 155 & 163 & 262 & 163 & 181 & 207 \\
\hline Vegetables & 1129 & 798 & 499 & 642 & 820 & 650 & 808 & 624 & 553 & 771 \\
\hline Sugar, jam, honey, chocolate and confectionery & 621 & 490 & 438 & 379 & 392 & 365 & 376 & 337 & 264 & 406 \\
\hline Food products n.e.c. & 498 & 351 & 436 & 281 & 363 & 362 & 505 & 307 & 220 & 386 \\
\hline Coffee, tea and cocoa & 276 & 124 & 177 & 132 & 89 & 157 & 184 & 120 & 90 & 148 \\
\hline $\begin{array}{l}\text { Mineral waters, soft drinks, fruit and vegetable } \\
\text { juices }\end{array}$ & 671 & 304 & 293 & 380 & 332 & 371 & 664 & 394 & 306 & 449 \\
\hline Unspecified food & 2544 & 296 & 190 & 269 & 623 & 152 & 701 & 218 & 572 & 688 \\
\hline Spirits & 184 & 88 & 41 & 51 & 63 & 35 & 85 & 20 & 10 & 72 \\
\hline Wine & 230 & 32 & 57 & 31 & 20 & 33 & 60 & 16 & 11 & 54 \\
\hline Beer & 130 & 90 & 78 & 91 & 97 & 173 & 254 & 118 & 112 & 145 \\
\hline Tobacco & 837 & 321 & 504 & 376 & 236 & 300 & 461 & 255 & 154 & 377 \\
\hline Clothing materials & 24 & 19 & 21 & 31 & 23 & 22 & 13 & 19 & 17 & 20 \\
\hline $\begin{array}{l}\text { Garments } \\
\text { Other articles of clothing and clothing }\end{array}$ & 2534 & 1492 & 1590 & 1939 & 1668 & 1580 & 2422 & 1665 & 1348 & 1889 \\
\hline accessories & 40 & 31 & 26 & 48 & 52 & 36 & 69 & 43 & 23 & 46 \\
\hline Cleaning, repair and hire of clothing & 11 & 7 & 14 & 13 & 9 & 10 & 13 & 12 & 7 & 10 \\
\hline Shoes and other footwear & 986 & 658 & 579 & 864 & 720 & 649 & 1098 & 681 & 542 & 809 \\
\hline Repair and hire of footwear & 2 & 6 & 3 & 10 & $7 \mid$ & 4 & 7 & 6 & 3 & 6 \\
\hline
\end{tabular}




\begin{tabular}{|c|c|c|c|c|c|c|c|c|c|c|}
\hline & $\begin{array}{r}\text { Western } \\
\text { Cape }\end{array}$ & \begin{tabular}{r|} 
Eastern \\
Cape
\end{tabular} & $\begin{array}{r}\text { Northern } \\
\text { Cape }\end{array}$ & \begin{tabular}{r|} 
Free \\
State
\end{tabular} & $\begin{array}{r}\text { KwaZulu- } \\
\text { Natal }\end{array}$ & North West & Gauteng & Mpumalanga & Limpopo & Total \\
\hline Actual rentals paid by tenants & 4136 & 1094 & 1088 & 1450 & 1475 & 2448 & 2950 & 1088 & 892 & 2017 \\
\hline Imputed rentals of owner-occupiers & 17688 & 4311 & 3318 & 4418 & 4952 & 3423 & 10758 & 3818 & 3065 & 7081 \\
\hline $\begin{array}{l}\text { Materials for maintenance and repair of the } \\
\text { dwelling }\end{array}$ & 578 & 316 & 175 & 228 & 243 & 175 & 685 & 227 & 109 & 370 \\
\hline $\begin{array}{l}\text { Service of the maintenance and repair of the } \\
\text { dwelling }\end{array}$ & 2384 & 537 & 398 & 449 & 290 & 248 & 600 & 240 & 183 & 608 \\
\hline Water and electricity & 209 & 113 & 426 & 162 & 1012 & 136 & 1046 & 223 & 164 & 530 \\
\hline Water supply & 632 & 178 & 290 & 498 & 282 & 354 & 521 & 133 & 136 & 356 \\
\hline Refuse collection & 259 & 71 & 147 & 206 & 42 & 69 & 149 & 71 & 27 & 110 \\
\hline Sewerage collection & 248 & 83 & 163 & 289 & 27 & 70 & 206 & 60 & 17 & 126 \\
\hline Other services relating to the dwelling & 1205 & 386 & 536 & 652 & 607 & 400 & 1090 & 466 & 88 & 675 \\
\hline Electricity & 1965 & 698 & 952 & 1219 & 829 & 1124 & 1058 & 919 & 675 & 1024 \\
\hline Gas & 50 & 49 & 56 & 53 & 37 & 12 & 34 & 15 & 21 & 36 \\
\hline Liquid fuels & 95 & 349 & 144 & 195 & 146 & 161 & 132 & 105 & 120 & 165 \\
\hline Solid fuels & 47 & 194 & 163 & 138 & 222 & 58 & 56 & 206 & 286 & 147 \\
\hline Furniture and furnishings & 890 & 536 & 634 & 822 & 525 & 657 & 880 & 815 & 583 & 709 \\
\hline Carpets and other floor covering & 155 & 72 & 37 & 105 & 92 & 34 & 94 & 90 & 19 & 84 \\
\hline Repair of furniture, furnishings and floor covering & 26 & 7 & 10 & 14 & 42 & 16 & 24 & 24 & 7 & 22 \\
\hline Household textiles & 773 & 674 & 769 & 848 & 565 & 700 & 744 & 949 & 620 & 712 \\
\hline Major household appliances & 650 & 367 & 597 & 504 & 417 & 391 & 458 & 523 & 373 & 455 \\
\hline Small electrical household appliances & 111 & 51 & 51 & 72 & 79 & 65 & 98 & 69 & 40 & 76 \\
\hline Repair of household appliances & 28 & 9 & 10 & 16 & 14 & 13 & 29 & 17 & 17 & 19 \\
\hline Glassware, tableware and household utensils & 98 & 110 & 69 & 143 & 72 & 88 & 136 & 133 & 93 & 108 \\
\hline Major tools and equipment & 46 & 16 & 20 & 15 & 17 & 15 & 30 & 13 & 7 & 21 \\
\hline Small tools and miscellaneous accessories & 69 & 41 & 41 & 48 & 43 & 40 & 54 & 31 & 30 & 46 \\
\hline Non-durable household goods & 594 & 348 & 409 & 431 & 354 & 412 & 625 & 457 & 376 & 463 \\
\hline Domestic services and household arcticles & 1912 & 608 & 645 & 1129 & 988 & 1161 & 1760 & 828 & 381 & 1154 \\
\hline Pharmaceutical products & 559 & 235 & 218 & 389 & 241 & 277 & 412 & 211 & 140 & 314 \\
\hline Other medical products & 23 & 8 & 8 & 8 & 9 & 6 & 14 & 12 & 5 & 11 \\
\hline Therapeutic appliances and equipment & 56 & 24 & 7 & 112 & 25 & 21 & 5 & 9 & 8 & 26 \\
\hline Medical services & 441 & 258 & 211 & 347 & 303 & 308 & 550 & 290 & 221 & 362 \\
\hline Dental services & 150 & 33 & 16 & 30 & 54 & 45 & 65 & 34 & 6 & 54 \\
\hline Paramedic services & 99 & 20 & 30 & 55 & 57 & 13 & 128 & 26 & 9 & 62 \\
\hline
\end{tabular}




\begin{tabular}{|c|c|c|c|c|c|c|c|c|c|c|}
\hline & $\begin{array}{r}\text { Western } \\
\text { Cape }\end{array}$ & \begin{tabular}{r|} 
Eastern \\
Cape
\end{tabular} & $\begin{array}{r}\text { Northern } \\
\text { Cape }\end{array}$ & \begin{tabular}{r|} 
Free \\
State
\end{tabular} & $\begin{array}{r}\text { KwaZulu- } \\
\text { Natal }\end{array}$ & North West & Gauteng & Mpumalanga & Limpopo & Total \\
\hline Hospital services & 126 & 33 & 136 & 220 & 76 & 55 & 192 & 28 & 30 & 105 \\
\hline Motor cars & 15010 & 4144 & 4333 & 6408 & 4048 & 3637 & 8890 & 6129 & 1703 & 6383 \\
\hline Motorcycles & 81 & & 20 & 6 & 14 & 66 & 88 & - & - & 37 \\
\hline Bicycles & 67 & 3 & 8 & 11 & 2 & 5 & 12 & 3 & 3 & 12 \\
\hline Animal-drawn vehicles & & 3 & 6 & 1 & 1 & 2 & 20 & 1 & 2 & 6 \\
\hline Spare parts and accessories & 655 & 196 & 334 & 374 & 281 & 355 & 411 & 228 & 194 & 339 \\
\hline Fuels and lubricants & 3453 & 1284 & 1360 & 1840 & 1499 & 1648 & 2915 & 1072 & 835 & 1939 \\
\hline $\begin{array}{l}\text { Maintenance and repair of personal transport } \\
\text { equipment }\end{array}$ & 566 & 127 & 140 & 230 & 216 & 189 & 397 & 141 & 80 & 260 \\
\hline $\begin{array}{l}\text { Other services in respect of personal transport } \\
\text { equipment }\end{array}$ & 514 & 126 & 136 & 233 & 240 & 240 & 456 & 199 & 178 & 291 \\
\hline Passenger transport by rail & 217 & 30 & 44 & 37 & 55 & 44 & 160 & 20 & 16 & 84 \\
\hline Passenger transport by road & 1155 & 1453 & 856 & 1446 & 1745 & 1575 & 2299 & 1512 & 1175 & 1646 \\
\hline Passenger transport by air & 319 & 80 & 30 & 66 & 91 & 34 & 369 & 9 & 25 & 159 \\
\hline Passenger transport by sea and inland waterway & 1 & & & 14 & 1 & & & & & 1 \\
\hline Other puchased transport services & 47 & 20 & 13 & 37 & 12 & 5 & 14 & 11 & 13 & 19 \\
\hline Cost for other modes of transport & 5 & 5 & 11 & 14 & 1 & 1 & 6 & 1 & - & 4 \\
\hline Postal services & 44 & 20 & 19 & 35 & 39 & 24 & 39 & 32 & 18 & 33 \\
\hline Telephone and telefax equipment & 268 & 219 & 192 & 251 & 214 & 189 & 252 & 275 & 221 & 235 \\
\hline Telephone and telefax services & 3480 & 1043 & 1160 & 1519 & 1511 & 1413 & 2283 & 1134 & 673 & 1702 \\
\hline $\begin{array}{l}\text { Equipment for the reception, recording and } \\
\text { reproduction of sound and pictures }\end{array}$ & 689 & 320 & 536 & 477 & 286 & 394 & 443 & 517 & 355 & 420 \\
\hline $\begin{array}{l}\text { Photographic and cinematographic equipment } \\
\text { and optical instruments }\end{array}$ & 121 & 29 & 29 & 45 & 60 & 23 & 106 & 13 & 17 & 61 \\
\hline Information processing equipment & 537 & 106 & 107 & 181 & 243 & 131 & 318 & 205 & 89 & 237 \\
\hline Recording media & 197 & 60 & 57 & 124 & 96 & 93 & 159 & 92 & 50 & 112 \\
\hline Major durables for outdoor recreation & 24 & 4 & 54 & 34 & 2 & 2 & 17 & 102 & & 19 \\
\hline $\begin{array}{l}\text { Musical instruments and major durables for } \\
\text { outdoor recreation }\end{array}$ & 27 & 7 & 4 & 12 & 12 & 12 & 23 & 10 & 28 & 17 \\
\hline $\begin{array}{l}\text { Maintenance and repair of other major durables } \\
\text { for recreation and culture }\end{array}$ & 17 & 5 & 7 & 11 & 6 & 18 & 12 & 9 & 7 & 10 \\
\hline Games, toys and hobbies & 260 & 20 & 26 & 56 & 30 & 34 & 96 & 28 & 18 & 68 \\
\hline $\begin{array}{l}\text { Equipment for sport, camping and open-air } \\
\text { recreation }\end{array}$ & 165 & 36 & 59 & 88 & 52 & 42 & 154 & 35 & 11 & 82 \\
\hline
\end{tabular}




\begin{tabular}{|c|c|c|c|c|c|c|c|c|c|c|}
\hline & $\begin{array}{r}\text { Western } \\
\text { Cape }\end{array}$ & $\begin{array}{r}\text { Eastern } \\
\text { Cape }\end{array}$ & $\begin{array}{r}\text { Northern } \\
\text { Cape }\end{array}$ & \begin{tabular}{r|} 
Free \\
State
\end{tabular} & $\begin{array}{r}\text { KwaZulu- } \\
\text { Natal }\end{array}$ & North West & Gauteng & Mpumalanga & Limpopo & Total \\
\hline Gardens, plants and flowers & 223 & 39 & 50 & 64 & 47 & 32 & 156 & 73 & 32 & 90 \\
\hline Pets and related products & 454 & 98 & 97 & 141 & 131 & 192 & 225 & 75 & 49 & 174 \\
\hline Veterinary and other services & 188 & 12 & 6 & 18 & 50 & 12 & 41 & 12 & 3 & 43 \\
\hline Recreational and sporting services & 419 & 61 & 41 & 108 & 115 & 95 & 263 & 74 & 31 & 158 \\
\hline Cultural services & 952 & 150 & 224 & 357 & 228 & 167 & 509 & 191 & 63 & 343 \\
\hline Games of chance & 243 & 70 & 133 & 152 & 111 & 190 & 442 & 172 & 94 & 209 \\
\hline Books & 247 & 62 & 41 & 93 & 92 & 73 & 144 & 43 & 69 & 108 \\
\hline Newspaper and periodicals & 380 & 116 & 141 & 142 & 152 & 131 & 436 & 165 & 82 & 229 \\
\hline Miscellaneous printed matter & 23 & 4 & 2 & 7 & 6 & 7 & 13 & 3 & 2 & 8 \\
\hline Stationery and drawing materials & 130 & 95 & 45 & 98 & 103 & 87 & 88 & 28 & 33 & 85 \\
\hline Package holidays & 191 & 23 & 8 & 69 & 229 & 16 & 156 & 3 & 3 & 107 \\
\hline Pre-primary and primary education & 588 & 268 & 167 & 194 & 285 & 233 & 513 & 208 & 202 & 341 \\
\hline Secondary education & 486 & 213 & 117 & 230 & 327 & 256 & 515 & 507 & 245 & 359 \\
\hline Tertiary education & 774 & 229 & 168 & 496 & 538 & 1075 & 543 & 277 & 451 & 520 \\
\hline Education not definable by level & 95 & 88 & 14 & 352 & 30 & 61 & 315 & 27 & 18 & 136 \\
\hline $\begin{array}{l}\text { Beverages in restaurants, cafes, canteens and } \\
\text { the like }\end{array}$ & 198 & 227 & 267 & 257 & 115 & 173 & 278 & 194 & 128 & 203 \\
\hline $\begin{array}{l}\text { Meals in restaurants, cafes, canteens and the } \\
\text { like }\end{array}$ & 1446 & 294 & 451 & 575 & 271 & 342 & 815 & 203 & 466 & 571 \\
\hline Accommodation services & 707 & 200 & 319 & 423 & 341 & 317 & 784 & 330 & 265 & 459 \\
\hline $\begin{array}{l}\text { Hairdressing salons and personal grooming } \\
\text { establishments }\end{array}$ & 126 & 18 & 11 & 44 & 6 & 25 & 73 & 22 & 15 & 42 \\
\hline Electrical appliances for personal care & 6 & 4 & 13 & 5 & 2 & 7 & 12 & 1 & 2 & 6 \\
\hline $\begin{array}{l}\text { Other appliances, articles and products for } \\
\text { personal care }\end{array}$ & 1154 & 383 & 560 & 581 & 429 & 530 & 981 & 510 & 357 & 648 \\
\hline Jewellery, clocks and watches & 209 & 69 & 60 & 175 & 165 & 82 & 190 & 80 & 72 & 139 \\
\hline Other personal effects & 215 & 86 & 75 & 111 & 93 & 85 & 153 & 83 & 71 & 116 \\
\hline Social protection services & 245 & 86 & 45 & 94 & 32 & 95 & 225 & 90 & 41 & 121 \\
\hline Insurance connected with the dwelling & 2294 & 558 & 645 & 925 & 753 & 1254 & 3434 & 968 & 401 & 1547 \\
\hline Insurance connected with health & 3375 & 1383 & 1212 & 2007 & 1145 & 2229 & 2699 & 1880 & 601 & 1914 \\
\hline Insurance connected with transport & 881 & 263 & 279 & 419 & 448 & 175 & 758 & 285 & 123 & 469 \\
\hline Other insurance & 566 & 789 & 867 & 902 & 549 & 503 & 598 & 515 & 429 & 610 \\
\hline Financial services n.e.c. & 1072 & 658 & 579 & 584 & 596 & 1439 & 948 & 876 & 339 & 790 \\
\hline Other services & 2296 & 1652 & 1305 & 1694 & 1747 & 1300 & 1883 & 1311 & 1123 & 1680 \\
\hline Consumption of unclassified diary items & 636 & & 47 & & 156 & & 175 & & 143 & 172 \\
\hline Total & 102977 & 39141 & 38389 & 50181 & 44612 & 43784 & 77700 & 43026 & 29042 & 56152 \\
\hline
\end{tabular}

Due to rounding, figures do not necessarily add up to totals

- No expenditure 


\section{Income}

Table 3.1 - Average household income by main income group and expenditure deciles

\begin{tabular}{|c|c|c|c|c|c|c|c|c|c|c|c|}
\hline \multirow[t]{2}{*}{ Source of income } & \multicolumn{10}{|c|}{ Expenditure deciles } & \multirow[t]{2}{*}{ Total } \\
\hline & Lower & 2 & 3 & 4 & 5 & 6 & 7 & 8 & 9 & Upper & \\
\hline \multicolumn{12}{|l|}{ Income from work } \\
\hline Household salaries and wages & 4147 & 7238 & 9521 & 11430 & 14352 & 19410 & 29862 & 49034 & 97620 & 238574 & 48152 \\
\hline Household self-employment and business & 458 & 890 & 1205 & 1500 & 1647 & 2334 & 4431 & 5708 & 9055 & 45705 & 7300 \\
\hline $\begin{array}{l}\text { Income from capital } \\
\text { Income from capital }\end{array}$ & 20 & 17 & 45 & 50 & 71 & 197 & 348 & 241 & 1734 & 5920 & 865 \\
\hline \multicolumn{12}{|l|}{ Pensions, social insurance, family allowances } \\
\hline Pension from previous employment & 130 & 95 & 210 & 184 & 396 & 484 & 922 & 2666 & 4871 & 5939 & 1590 \\
\hline Annuities from own investment & 40 & 9 & 15 & 11 & 34 & 45 & 106 & 523 & 851 & 1993 & 363 \\
\hline Old age pensions & 1226 & 1872 & 2119 & 2238 & 2619 & 2308 & 2358 & 3089 & 1605 & 899 & 2033 \\
\hline Disability grants & 643 & 892 & 1015 & 1109 & 1200 & 1138 & 939 & 956 & 332 & 115 & 834 \\
\hline Family and other allowances & 989 & 1580 & 1846 & 1911 & 1996 & 2144 & 1838 & 1404 & 1244 & 1102 & 1605 \\
\hline Workmen's compensation funds & 21 & 22 & 21 & 81 & 23 & 53 & 51 & 106 & 334 & 140 & 85 \\
\hline \multicolumn{12}{|l|}{ Income from individuals } \\
\hline Alimony, palimony and other allowances & 415 & 616 & 651 & 676 & 808 & 881 & 1022 & 1050 & 1031 & 1726 & 888 \\
\hline Other income from individuals & 172 & 203 & 233 & 297 & 245 & 395 & 400 & 360 & 405 & 433 & 314 \\
\hline \multicolumn{12}{|l|}{ Other income } \\
\hline Other income & 692 & 597 & 583 & 713 & 1197 & 1170 & 1385 & 2383 & 3669 & 19371 & 3179 \\
\hline Benefits, cash, donations and gifts & 103 & 100 & 114 & 115 & 152 & 223 & 216 & 367 & 641 & 947 & 298 \\
\hline \multicolumn{12}{|l|}{$\begin{array}{l}\text { Imputed rent on owned dwelling ( } 7 \% \text { per year } \\
\text { of dwelling) }\end{array}$} \\
\hline $\begin{array}{l}\text { Imputed rent on owned dwelling ( } 7 \% \text { per year of } \\
\text { dwelling) }\end{array}$ & 443 & 691 & 910 & 1096 & 1397 & 1833 & 2549 & 4871 & 13393 & 43562 & 7081 \\
\hline Total & 9500 & 14823 & 18488 & 21412 & 26137 & 32615 & 46428 & 72755 & 136786 & 366425 & 74589 \\
\hline
\end{tabular}

Due to rounding, figures do not necessarily add up to totals 


\section{Income}

Table 3.2 - Average household income by main income group and income deciles

\begin{tabular}{|c|c|c|c|c|c|c|c|c|c|c|c|}
\hline \multirow[t]{2}{*}{ Source of income } & \multicolumn{10}{|c|}{ Income deciles } & \multirow[t]{2}{*}{ Total } \\
\hline & Lower & 2 & 3 & 4 & 5 & 6 & 7 & 8 & 9 & Upper & \\
\hline \multicolumn{12}{|l|}{ Income from work } \\
\hline Household salaries and wages & 1159 & 2974 & 4400 & 6625 & 10532 & 16137 & 27979 & 49227 & 91164 & 271256 & 48152 \\
\hline \multicolumn{12}{|l|}{ Income from capital } \\
\hline Income from capital & 14 & 30 & 38 & 69 & 77 & 124 & 193 & 573 & 923 & 6610 & 865 \\
\hline \multicolumn{12}{|l|}{ Pensions, social insurance, family allowances } \\
\hline Pension from previous employment & 11 & 37 & 95 & 142 & 387 & 745 & 1234 & 2280 & 5211 & 5759 & 1590 \\
\hline Annuities from own investment & 1 & 3 & 11 & 11 & 38 & 89 & 206 & 388 & 1024 & 1857 & 363 \\
\hline Old age pensions & 31 & 1596 & 2309 & 2540 & 3216 & 3081 & 2317 & 1850 & 1594 & 1795 & 2033 \\
\hline Disability grants & 43 & 764 & 1113 & 1183 & 1401 & 1550 & 989 & 829 & 370 & 95 & 834 \\
\hline Workmen's compensation funds & 8 & 14 & 17 & 49 & 79 & 48 & 54 & 72 & 173 & 336 & 85 \\
\hline \multicolumn{12}{|l|}{ Income from individuals } \\
\hline Alimony, palimony and other allowances & 539 & 676 & 718 & 1061 & 901 & 878 & 936 & 714 & 1178 & 1276 & 888 \\
\hline Other income from individuals & 190 & 285 & 373 & 331 & 332 & 263 & 294 & 216 & 511 & 348 & 314 \\
\hline \multicolumn{12}{|l|}{ Other income } \\
\hline Other income & 443 & 555 & 591 & 849 & 921 & 1340 & 1421 & 1783 & 2913 & 20973 & 3179 \\
\hline Benefits, cash, donations and gifts & 100 & 119 & 112 & 171 & 185 & 188 & 230 & 318 & 640 & 917 & 298 \\
\hline $\begin{array}{l}\text { Imputed rent on owned dwelling ( } 7 \% \text { per year of } \\
\text { dwelling) }\end{array}$ & & & & & & & & & & & \\
\hline $\begin{array}{l}\text { Imputed rent on owned dwelling (7\% per year of } \\
\text { dwelling) }\end{array}$ & 543 & 784 & 1141 & 1428 & 1460 & 1952 & 2656 & 5323 & 12888 & 42622 & 7081 \\
\hline Total & 4312 & 9587 & 13297 & 17626 & 22974 & 30522 & 43572 & 69495 & 128785 & 405617 & 74589 \\
\hline
\end{tabular}

Due to rounding, figures do not necessarily add up to totals 
Table 3.3 - Average household income by main income group and population group of household head

\begin{tabular}{|c|c|c|c|c|c|c|}
\hline Source of income & Black African & Coloured & Indian/ Asian & White & Unspecified & Total \\
\hline \multicolumn{7}{|l|}{ Income from work } \\
\hline Household salaries and wages & 24666 & 59037 & 91197 & 174171 & 23500 & 48152 \\
\hline Household self-employment and business & 2893 & 2968 & 19200 & 33701 & 34653 & 7300 \\
\hline Income from capital & & & & & & \\
\hline Income from capital & 201 & 670 & 944 & 4870 & 7757 & 865 \\
\hline \multicolumn{7}{|l|}{ Pensions, social insurance, family allowances } \\
\hline Pension from previous employment & 386 & 1056 & 1559 & 9152 & 178 & 1590 \\
\hline Annuities from own investment & 49 & 82 & 182 & 2414 & 3626 & 363 \\
\hline Old age pensions & 1972 & 1988 & 2291 & 2391 & 504 & 2033 \\
\hline Disability grants & 863 & 1369 & 1030 & 308 & 44 & 834 \\
\hline Family and other allowances & 1777 & 1082 & 631 & 1085 & 1324 & 1605 \\
\hline Workmen's compensation funds & 53 & 113 & 86 & 262 & & 85 \\
\hline \multicolumn{7}{|l|}{ Income from individuals } \\
\hline Alimony, palimony and other allowances & 756 & 683 & 693 & 1846 & - & 888 \\
\hline Other income from individuals & 305 & 301 & 160 & 408 & 157 & 314 \\
\hline \multicolumn{7}{|l|}{ Other income } \\
\hline Other income & 1338 & 2536 & 1981 & 14837 & 2545 & 3179 \\
\hline Benefits, cash, donations and gifts & 180 & 459 & 345 & 898 & 139 & 298 \\
\hline Imputed rent on owned dwelling (7\% per year of dwelling) & & & & & & \\
\hline Imputed rent on owned dwelling ( $7 \%$ per year of dwelling) & 2272 & 7080 & 14243 & 34525 & 4907 & 7081 \\
\hline Total & 37711 & 79423 & 134543 & 280870 & 79334 & 74589 \\
\hline
\end{tabular}

Due to rounding, figures do not necessarily add up to totals

- No income 


\section{Income}

Table 3.4 - Average household income by main income group and province

\begin{tabular}{|c|c|c|c|c|c|c|c|c|c|c|}
\hline Source of income & $\begin{array}{r}\text { Western } \\
\text { Cape }\end{array}$ & $\begin{array}{r}\text { Eastern } \\
\text { Cape }\end{array}$ & $\begin{array}{r}\text { Northern } \\
\text { Cape }\end{array}$ & Free State & $\begin{array}{r}\text { KwaZulu- } \\
\text { Natal }\end{array}$ & $\begin{array}{l}\text { North } \\
\text { West }\end{array}$ & Gauteng & Mpumalanga & Limpopo & Total \\
\hline Income from work & & & & & & & & & & \\
\hline Household salaries and wages & 77471 & 26543 & 29865 & 35062 & 38974 & 38477 & 79945 & 36068 & 19306 & 48152 \\
\hline $\begin{array}{l}\text { Household self-employment and business } \\
\text { Income from capital }\end{array}$ & 15404 & 4479 & 6118 & 9291 & 4198 & 5419 & 10149 & 5992 & 2988 & 7300 \\
\hline $\begin{array}{l}\text { Income from capital } \\
\text { Pensions, social insurance, family } \\
\text { allowances }\end{array}$ & 3922 & 357 & 359 & 984 & 333 & 478 & 700 & 142 & 627 & 865 \\
\hline Pension from previous employment & 2936 & 1478 & 1724 & 1701 & 1328 & 1232 & 1766 & 1561 & 636 & 1590 \\
\hline Annuities from own investment & 1093 & 265 & 167 & 314 & 223 & 95 & 534 & 126 & 53 & 363 \\
\hline Old age pensions & 1593 & 2622 & 1788 & 1564 & 2560 & 1677 & 1476 & 1985 & 2716 & 2033 \\
\hline Disability grants & 755 & 1175 & 1440 & 775 & 1215 & 737 & 439 & 565 & 865 & 834 \\
\hline Family and other allowances & 1001 & 2050 & 1875 & 1565 & 1888 & 1449 & 996 & 1971 & 2346 & 1605 \\
\hline $\begin{array}{l}\text { Workmen's compensation funds } \\
\text { Income from individuals }\end{array}$ & 139 & 82 & 27 & 51 & 54 & 199 & 77 & 126 & 38 & 85 \\
\hline Alimony, palimony and other allowances & 1157 & 948 & 1194 & 961 & 784 & 838 & 726 & 728 & 1112 & 888 \\
\hline $\begin{array}{l}\text { Other income from individuals } \\
\text { Other income }\end{array}$ & 375 & 354 & 288 & 475 & 248 & 165 & 118 & 303 & 768 & 314 \\
\hline Other income & 10831 & 2959 & 1228 & 2853 & 1619 & 1965 & 3112 & 1087 & 1725 & 3179 \\
\hline $\begin{array}{l}\text { Benefits, cash, donations and gifts } \\
\text { Imputed rent on owned dwelling ( } 7 \% \text { per year } \\
\text { of dwelling) }\end{array}$ & 663 & 306 & 304 & 687 & 175 & 156 & 283 & 90 & 141 & 298 \\
\hline $\begin{array}{l}\text { Imputed rent on owned dwelling ( } 7 \% \text { per year of } \\
\text { dwelling) }\end{array}$ & 17688 & 4311 & 3318 & 4418 & 4952 & 3423 & 10758 & 3818 & 3065 & 7081 \\
\hline Total & 135029 & 47930 & 49697 & 60700 & 58551 & 56310 & 111079 & 54562 & 36386 & 74589 \\
\hline
\end{tabular}

Due to rounding, figures do not necessarily add up to totals 
Table 3.5 - Average household income by main income group and type of settlement

\begin{tabular}{|c|c|c|c|}
\hline Source of income & Urban & Rural & Total \\
\hline \multicolumn{4}{|l|}{ Income from work } \\
\hline Household salaries and wages & 66310 & 14250 & 48152 \\
\hline $\begin{array}{l}\text { Household self-employment and business } \\
\text { Income from capital }\end{array}$ & 8822 & 4460 & 7300 \\
\hline Income from capital & 1148 & 338 & 865 \\
\hline \multicolumn{4}{|l|}{ Pensions, social insurance, family allowances } \\
\hline Pension from previous employment & 2214 & 426 & 1590 \\
\hline Annuities from own investment & 525 & 61 & 363 \\
\hline Old age pensions & 1546 & 2942 & 2033 \\
\hline Disability grants & 686 & 1109 & 834 \\
\hline Family and other allowances & 1172 & 2414 & 1605 \\
\hline Workmen's compensation funds & 114 & 31 & 85 \\
\hline \multicolumn{4}{|l|}{ Income from individuals } \\
\hline Alimony, palimony and other allowances & 860 & 940 & 888 \\
\hline Other income from Individuals & 268 & 402 & 314 \\
\hline \multicolumn{4}{|l|}{ Other income } \\
\hline Other income & 4157 & 1354 & 3179 \\
\hline Benefits, cash, donations and gifts & 383 & 139 & 298 \\
\hline Imputed rent on owned dwelling ( $7 \%$ per year of dwelling) & & & \\
\hline Imputed rent on owned dwelling ( $7 \%$ per year of dwelling) & 9806 & 1993 & 7081 \\
\hline Total & 98011 & 30859 & 74589 \\
\hline
\end{tabular}

Due to rounding, figures do not necessarily add up to totals 
Table 3.6 - Percentage distribution of annual household income by main income group and expenditure deciles

\begin{tabular}{|c|c|c|c|c|c|c|c|c|c|c|c|}
\hline \multirow[t]{2}{*}{ Source of income } & \multicolumn{10}{|c|}{ Expenditure deciles } & \multirow[t]{2}{*}{ Total } \\
\hline & Lower & 2 & 3 & 4 & 5 & 6 & 7 & 8 & 9 & Upper & \\
\hline \multicolumn{12}{|l|}{ Income from work } \\
\hline Household salaries and wages & 43,7 & 48,8 & 51,5 & 53,4 & 54,9 & 59,5 & 64,3 & 67,4 & 71,4 & 65,1 & 64,6 \\
\hline $\begin{array}{l}\text { Household self-employment and business } \\
\text { Income from capital }\end{array}$ & 4,8 & 6,0 & 6,5 & 7,0 & 6,3 & 7,2 & 9,5 & 7,8 & 6,6 & 12,5 & 9,8 \\
\hline Income from capital & 0,2 & 0,1 & 0,2 & 0,2 & 0,3 & 0,6 & 0,8 & 0,3 & 1,3 & 1,6 & 1,2 \\
\hline \multicolumn{12}{|l|}{ Pensions, social insurance, family allowances } \\
\hline Pension from previous employment & 1,4 & 0,6 & 1,1 & 0,9 & 1,5 & 1,5 & 2,0 & 3,7 & 3,6 & 1,6 & 2,1 \\
\hline Annuities from own investment & 0,4 & 0,1 & 0,1 & 0,1 & 0,1 & 0,1 & 0,2 & 0,7 & 0,6 & 0,5 & 0,5 \\
\hline Old age pensions & 12,9 & 12,6 & 11,5 & 10,5 & 10,0 & 7,1 & 5,1 & 4,3 & 1,2 & 0,3 & 2,7 \\
\hline Disability grants & 6,8 & 6,0 & 5,5 & 5,2 & 4,6 & 3,5 & 2,0 & 1,3 & 0,2 & 0,0 & 1,1 \\
\hline Workmen's compensation funds & 0,2 & 0,2 & 0,1 & 0,4 & 0,1 & 0,2 & 0,1 & 0,2 & 0,2 & 0,0 & 0,1 \\
\hline \multicolumn{12}{|l|}{ Income from individuals } \\
\hline Alimony, palimony and other allowances & 4,4 & 4,2 & 3,5 & 3,2 & 3,1 & 2,7 & 2,2 & 1,4 & 0,8 & 0,5 & 1,2 \\
\hline Other income from individuals & 1,8 & 1,4 & 1,3 & 1,4 & 0,9 & 1,2 & 0,9 & 0,5 & 0,3 & 0,1 & 0,4 \\
\hline \multicolumn{12}{|l|}{ Other income } \\
\hline Other income & 7,3 & 4,0 & 3,2 & 3,3 & 4,6 & 3,6 & 3,0 & 3,3 & 2,7 & 5,3 & 4,3 \\
\hline Benefits, cash, donations and gifts & 1,1 & 0,7 & 0,6 & 0,5 & 0,6 & 0,7 & 0,5 & 0,5 & 0,5 & 0,3 & 0,4 \\
\hline Imputed rent on owned dwelling ( $7 \%$ per year of dwelling & & & & & & & & & & & \\
\hline Imputed rent on owned dwelling ( $7 \%$ per year of dwelling) & 4,7 & 4,7 & 4,9 & 5,1 & 5,4 & 5,6 & 5,5 & 6,7 & 9,8 & 11,9 & 9,5 \\
\hline Total & 100,0 & 100,0 & 100,0 & 100,0 & 100,0 & 100,0 & 100,0 & 100,0 & 100,0 & 100,0 & 100,0 \\
\hline
\end{tabular}

Due to rounding, figures do not necessarily add up to totals 
Table 3.7 - Percentage distribution of annual household income by main income group and sex of household head

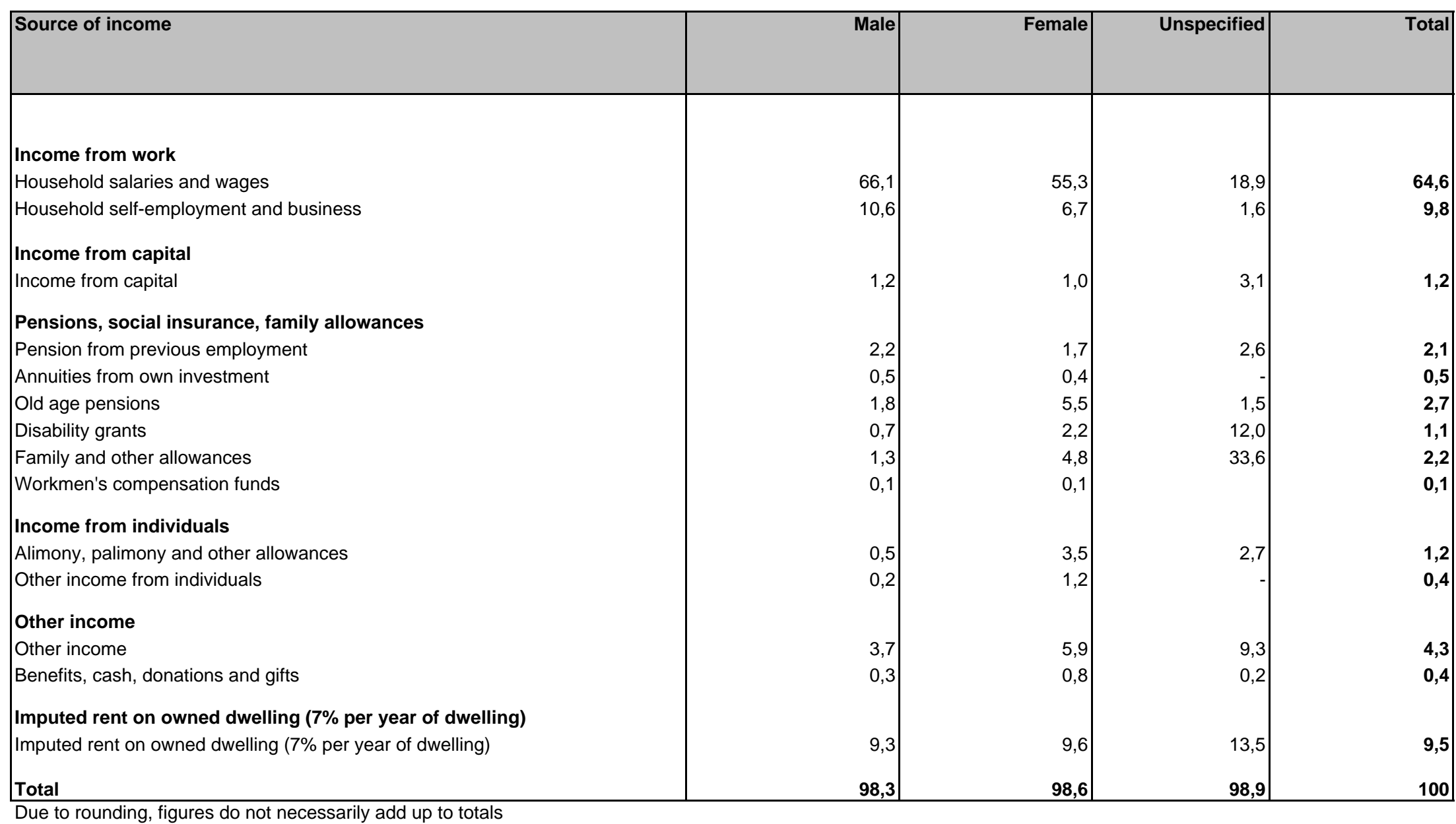

- No income 


\section{Income}

Table 3.8 - Percentage distribution of annual household income by main income group and income deciles

\begin{tabular}{|c|c|c|c|c|c|c|c|c|c|c|c|}
\hline \multirow[t]{2}{*}{ Source of income } & \multicolumn{10}{|c|}{ Income deciles } & \multirow[t]{2}{*}{ Total } \\
\hline & Lower & 2 & 3 & 4 & 5 & 6 & 7 & 8 & 9 & Upper & \\
\hline \multicolumn{12}{|l|}{ Income from work } \\
\hline Household salaries and wages & 26,9 & 31,0 & 33,1 & 37,6 & 45,8 & 52,9 & 64,2 & 70,8 & 70,8 & 66,9 & 64,6 \\
\hline Household self-employment and business & 6,8 & 4,9 & 5,5 & 4,9 & 5,1 & 6,5 & 7,6 & 6,5 & 7,2 & 12,4 & 9,8 \\
\hline Income from capital & & & & & & & & & & & \\
\hline Income from capital & 0,3 & 0,3 & 0,3 & 0,4 & 0,3 & 0,4 & 0,4 & 0,8 & 0,7 & 1,6 & 1,2 \\
\hline \multicolumn{12}{|l|}{ Pensions, social insurance, family allowances } \\
\hline Pension from previous employment & 0,3 & 0,4 & 0,7 & 0,8 & 1,7 & 2,4 & 2,8 & 3,3 & 4,1 & 1,4 & 2,1 \\
\hline Annuities from own investment & 0,0 & 0,0 & 0,1 & 0,1 & 0,2 & 0,3 & 0,5 & 0,6 & 0,8 & 0,5 & 0,5 \\
\hline Old age pensions & 0,7 & 16,7 & 17,4 & 14,4 & 14,0 & 10,1 & 5,3 & 2,7 & 1,2 & 0,4 & 2,7 \\
\hline Disability grants & 1,0 & 8,0 & 8,4 & 6,7 & 6,1 & 5,1 & 2,3 & 1,2 & 0,3 & 0,0 & 1,1 \\
\hline Family and other allowances & 21,7 & 13,4 & 12,4 & 13,1 & 9,9 & 7,1 & 4,0 & 2,0 & 0,7 & 0,4 & 2,2 \\
\hline Workmen's compensation funds & 0,2 & 0,1 & 0,1 & 0,3 & 0,4 & 0,2 & 0,1 & 0,1 & 0,1 & 0,1 & 0,1 \\
\hline \multicolumn{12}{|l|}{ Income from individuals } \\
\hline Alimony, palimony and other allowances & 12,5 & 7,1 & 5,4 & 6,0 & 3,9 & 2,9 & 2,2 & 1,0 & 0,9 & 0,3 & 1,2 \\
\hline Other income from individuals & 4,4 & 3,0 & 2,8 & 1,9 & 1,4 & 0,9 & 0,7 & 0,3 & 0,4 & 0,1 & 0,4 \\
\hline \multicolumn{12}{|l|}{ Other income } \\
\hline Other income & 10,3 & 5,8 & 4,4 & 4,8 & 4,0 & 4,4 & 3,3 & 2,6 & 2,3 & 5,2 & 4,3 \\
\hline Benefits, cash, donations and gifts & 2,3 & 1,2 & 0,8 & 1,0 & 0,8 & 0,6 & 0,5 & 0,5 & 0,5 & 0,2 & 0,4 \\
\hline Imputed rent on owned dwelling ( $7 \%$ per year of dwelling) & & & & & & & & & & & \\
\hline Imputed rent on owned dwelling ( $7 \%$ per year of dwelling) & 12,6 & 8,2 & 8,6 & 8,1 & 6,4 & 6,4 & 6,1 & 7,7 & 10,0 & 10,5 & 9,5 \\
\hline Total & 100,0 & 100,0 & 100,0 & 100,0 & 100,0 & 100,0 & 100,0 & 100,0 & 100,0 & 100,0 & 100,0 \\
\hline
\end{tabular}

Due to rounding, figures do not necessarily add up to totals 
Table 3.9 - Percentage distribution of annual household income by main income group and population group of household head

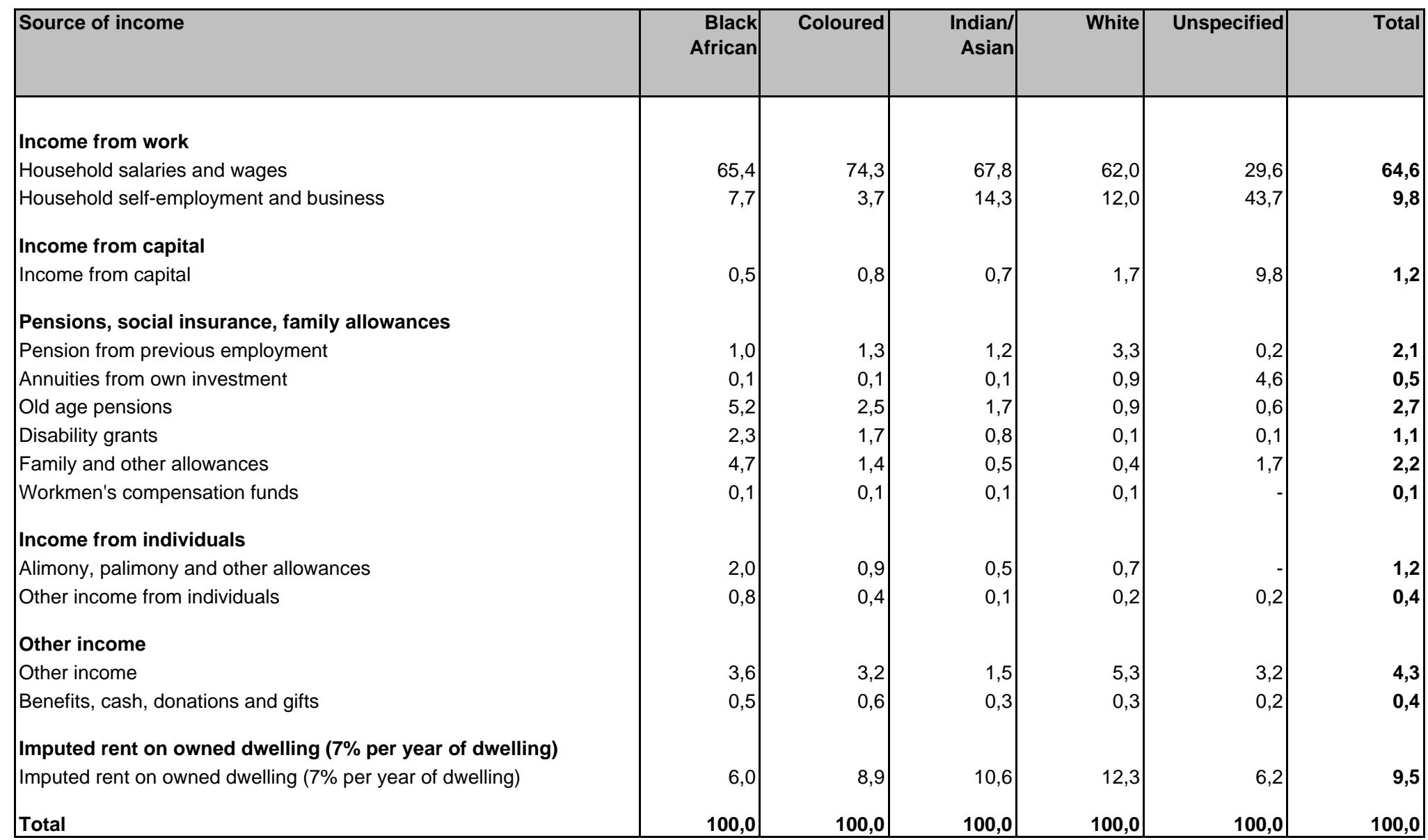

Due to rounding, figures do not necessarily add up to totals

- No income 


\section{Income}

Table 3.10 - Percentage distribution of annual household income by main income group and province

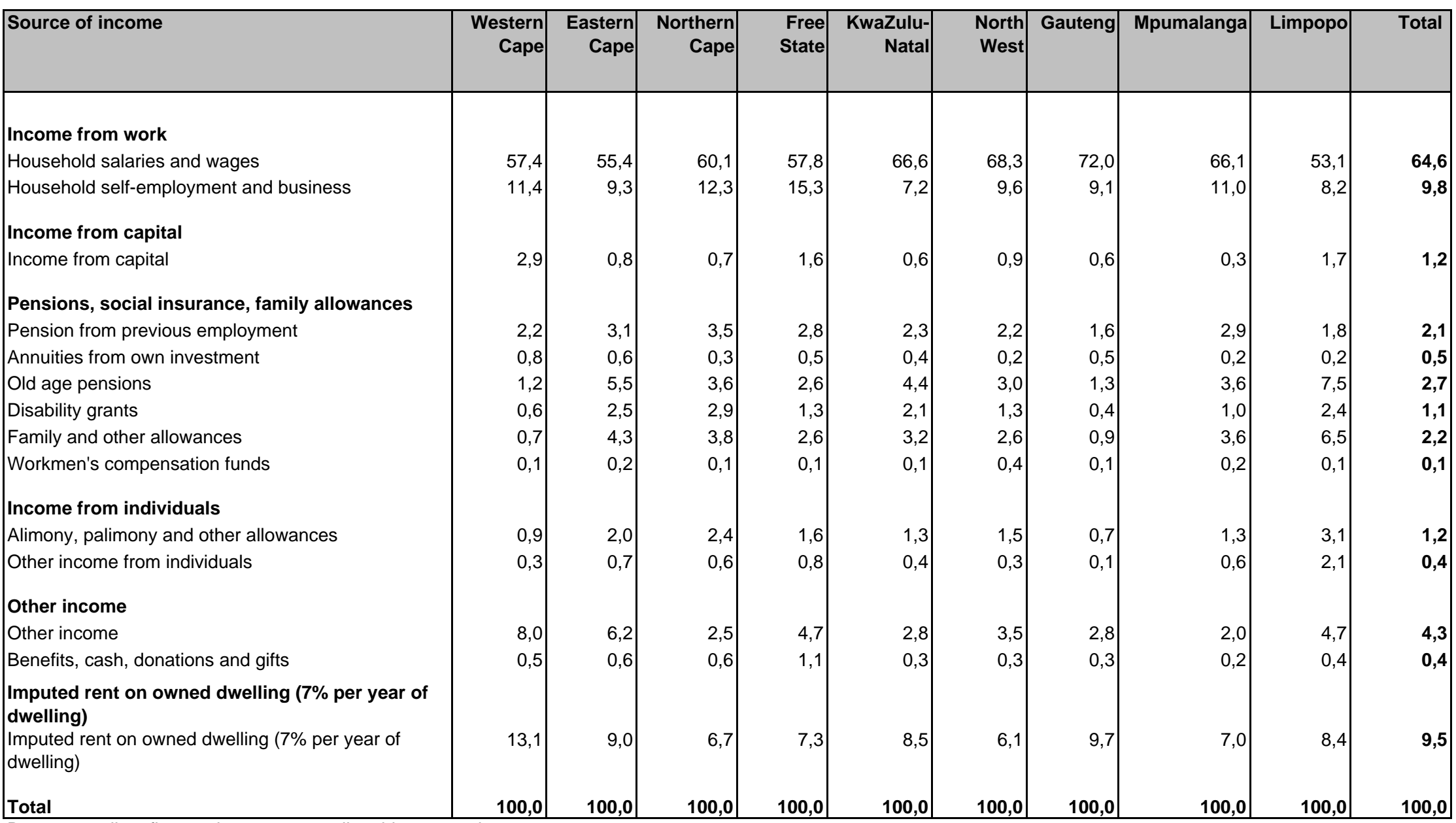

Due to rounding, figures do not necessarily add up to totals 
Table 3.11 - Percentage distribution of annual household income by main income group and type of settlement

\begin{tabular}{|c|c|c|c|}
\hline Source of income & Urban & Rural & Total \\
\hline \multicolumn{4}{|l|}{ Income from work } \\
\hline Household salaries and wages & 67,7 & 46,2 & 64,6 \\
\hline Household self-employment and business & 9,0 & 14,5 & 9,8 \\
\hline \multicolumn{4}{|l|}{ Income from capital } \\
\hline Income from capital & 1,2 & 1,1 & 1,2 \\
\hline \multicolumn{4}{|l|}{ Pensions, social insurance, family allowances } \\
\hline Pension from previous employment & 2,3 & 1,4 & 2,1 \\
\hline Annuities from own investment & 0,5 & 0,2 & 0,5 \\
\hline Old age pensions & 1,6 & 9,5 & 2,7 \\
\hline Disability grants & 0,7 & 3,6 & 1,1 \\
\hline Family and other allowances & 1,2 & 7,8 & 2,2 \\
\hline Workmen's compensation funds & 0,1 & 0,1 & 0,1 \\
\hline \multicolumn{4}{|l|}{ Income from individuals } \\
\hline Alimony, palimony and other allowances & 0,9 & 3,1 & 1,2 \\
\hline Other income from individuals & 0,3 & 1,3 & 0,4 \\
\hline \multicolumn{4}{|l|}{ Other income } \\
\hline Other income & 4,2 & 4,4 & 4,3 \\
\hline Benefits, cash, donations and gifts & 0,4 & 0,5 & 0,4 \\
\hline \multicolumn{4}{|l|}{ Imputed rent on owned dwelling ( $7 \%$ per year of dwelling) } \\
\hline Imputed rent on owned dwelling (7\% per year of dwelling) & 10,0 & 6,5 & 9,5 \\
\hline Total & 100 & 100 & 100 \\
\hline
\end{tabular}

Due to rounding, figures do not necessarily add up to totals 


\section{Income}

Table 3.12 - Income by main income group

\begin{tabular}{|c|c|c|c|}
\hline Source of income & $\begin{array}{r}\text { Total income } \\
\text { (Million Rand) }\end{array}$ & Percentage & $\begin{array}{r}\text { Average income } \\
\text { (Rand) }\end{array}$ \\
\hline Income from work & 690805 & 74,3 & 55453 \\
\hline Household salaries and wages & 599859 & 64,6 & 48152 \\
\hline Household self-employment and business & 90946 & 9,8 & 7300 \\
\hline Income from capital & 10779 & 1,2 & 865 \\
\hline Income from capital & 10779 & 1,2 & 865 \\
\hline Pensions, social insurance, family allowances & 81106 & 8,7 & 6511 \\
\hline Pension from previous employment & 19812 & 2,1 & 1590 \\
\hline Annuities from own investment & 4520 & 0,5 & 363 \\
\hline Old age pensions & 25326 & 2,7 & 2033 \\
\hline Disability grants & 10387 & 1,1 & 834 \\
\hline Family and other allowances & 20001 & 2,2 & 1605 \\
\hline Workmen's compensation funds & 1061 & 0,1 & 85 \\
\hline Income from individuals & 14976 & 1,6 & 1202 \\
\hline Alimony, palimony and other allowances & 11060 & 1,2 & 888 \\
\hline Other income from individuals & 3916 & 0,4 & 314 \\
\hline Other income & 43315 & 4,7 & 3477 \\
\hline Other income & 39604 & 4,3 & 3179 \\
\hline Benefits, cash, donations and gifts & 3711 & 0,4 & 298 \\
\hline Imputed rent on owned dwelling ( $7 \%$ per year of dwelling) & 88213 & 9,5 & 7081 \\
\hline Imputed rent on owned dwelling ( $7 \%$ per year of dwelling) & 88213 & 9,5 & 7081 \\
\hline Total & 929194 & 100,0 & 74589 \\
\hline
\end{tabular}

Due to rounding, figures do not necessarily add up to totals 


\section{Ownership of assets}

\section{Table 4.1 - Ownership of assets by sex of household head}

\begin{tabular}{|c|c|c|c|}
\hline & Male & Female & ${ }^{*}$ Total \\
\hline Number of households in sample & 11815 & 9310 & 21144 \\
\hline Number of households in population & 7607409 & 4841472 & 12457580 \\
\hline Own or have access to & \multicolumn{3}{|c|}{ Percentage of total in each column } \\
\hline Radio & 76,3 & 72,9 & 75,0 \\
\hline Stereo/HiFi & 45,2 & 36,0 & 41,6 \\
\hline Tape recorder & 37,8 & 31,4 & 35,3 \\
\hline Television & 68,2 & 64,2 & 66,6 \\
\hline Video cassette recorder/DVD & 40,2 & 28,4 & 35,6 \\
\hline Refrigerator/ freezer & 63,9 & 63,4 & 63,7 \\
\hline Stove, gas or electric & 80,0 & 76,3 & 78,6 \\
\hline Microwave & 35,9 & 27,4 & 32,6 \\
\hline Washing machine & 32,4 & 16,1 & 26,1 \\
\hline Motor vehicle & 22,1 & 11,1 & 17,8 \\
\hline Motorcycle/scooter & 2,5 & 0,9 & 1,9 \\
\hline Sewing/knitting machine & 11,9 & 10,2 & 11,2 \\
\hline Donkey cart/ox cart & 1,2 & 1,0 & 1,1 \\
\hline Plough & 4,6 & 6,8 & 5,5 \\
\hline Tractor & 1,4 & 1,4 & 1,4 \\
\hline Wheelbarrow & 32,8 & 35,5 & 33,8 \\
\hline Grinding mill & 2,8 & 2,1 & 2,5 \\
\hline Bicycle & 19,2 & 11,4 & 16,2 \\
\hline Computer & 18,3 & 9,0 & 14,7 \\
\hline Canoe/boat & 1,4 & 0,6 & 1,1 \\
\hline Motorboat & 1,0 & 0,4 & 0,7 \\
\hline Camera & 22,8 & 13,3 & 19,1 \\
\hline Bed & 97,9 & 97,2 & 97,6 \\
\hline Cellular telephone & 71,8 & 68,2 & 70,4 \\
\hline Landline telephone & 24,5 & 18,2 & 22,0 \\
\hline Satellite dish & 7,3 & 3,1 & 5,7 \\
\hline Internet service & 8,1 & 4,0 & 6,5 \\
\hline
\end{tabular}

*Total includes households with unspecified sex of household head

Due to rounding, figures do not necessarily add up to totals 


\section{Ownership of assets}

Table 4.2 - Ownership of assets by household income deciles

\begin{tabular}{|c|c|c|c|c|c|c|c|c|c|c|c|}
\hline & & & & & Income & deciles & & & & & Total \\
\hline & Lower & 2 & 3 & 4 & 5 & 6 & 7 & 8 & 9 & Upper & \\
\hline $\begin{array}{l}\text { Number of households in sample } \\
\text { Number of households in population }\end{array}$ & $\begin{array}{r}2198 \\
1245107 \\
\end{array}$ & $\begin{array}{r}2548 \\
1245102 \\
\end{array}$ & $\begin{array}{r}2467 \\
1247045 \\
\end{array}$ & $\begin{array}{r}2326 \\
1245554 \\
\end{array}$ & $\begin{array}{r}2254 \\
1245597 \\
\end{array}$ & $\begin{array}{r}2114 \\
1245638 \\
\end{array}$ & $\begin{array}{r}1999 \\
1246005 \\
\end{array}$ & $\begin{array}{r}1978 \\
1244654 \\
\end{array}$ & $\begin{array}{r}1833 \\
1247055 \\
\end{array}$ & $\begin{array}{r}1427 \\
1245823 \\
\end{array}$ & $\begin{array}{r}21144 \\
12457580 \\
\end{array}$ \\
\hline Own or have access to & & & & & Percentage & of total in & each colum & & & & \\
\hline Radio & 63,4 & 69,0 & 71,0 & 71,0 & 75,2 & 72,7 & 76,3 & 77,7 & 84,5 & 89,0 & 75,0 \\
\hline Stereo/HiFi & 18,5 & 20,5 & 25,5 & 29,5 & 34,3 & 36,4 & 45,8 & 54,4 & 69,9 & 81,3 & 41,6 \\
\hline Tape recorder & 20,0 & 21,6 & 25,2 & 26,6 & 29,9 & 32,2 & 37,5 & 41,8 & 55,4 & 63,0 & 35,3 \\
\hline Television & 33,5 & 40,6 & 51,0 & 56,5 & 63,7 & 65,9 & 75,4 & 86,5 & 94,9 & 98,3 & 66,6 \\
\hline Video cassette recorder/DVD & 8,3 & 11,0 & 12,8 & 15,7 & 21,6 & 27,0 & 38,8 & 55,3 & 74,1 & 91,3 & 35,6 \\
\hline Refrigerator/ freezer & 29,7 & 35,9 & 45,8 & 52,6 & 58,0 & 61,7 & 72,8 & 85,6 & 96,3 & 99,0 & 63,7 \\
\hline Stove, gas or electric & 61,7 & 62,4 & 67,1 & 68,2 & 74,7 & 78,0 & 85,0 & 91,7 & 97,2 & 99,6 & 78,6 \\
\hline Microwave & 6,0 & 8,3 & 8,4 & 12,1 & 15,8 & 22,6 & 30,9 & 49,6 & 79,4 & 92,6 & 32,6 \\
\hline Washing machine & 2,9 & 3,8 & 4,2 & 6,0 & 8,1 & 14,0 & 19,1 & 36,2 & 71,6 & 94,7 & 26,1 \\
\hline Motor vehicle & 1,2 & 1,9 & 2,0 & 2,5 & 3,0 & 6,0 & 8,3 & 19,1 & 52,2 & 82,0 & 17,8 \\
\hline Motorcycle/scooter & 0,2 & 0,4 & 0,2 & 0,1 & 0,1 & 0,4 & 0,9 & 2,1 & 4,4 & 9,8 & 1,9 \\
\hline Sewing/knitting machine & 2,6 & 4,2 & 4,3 & 6,8 & 6,9 & 8,5 & 9,6 & 13,2 & 21,7 & 34,3 & 11,2 \\
\hline Donkey cart/ox cart & 0,7 & 1,2 & 1,4 & 1,5 & 1,5 & 1,5 & 0,5 & 0,7 & 0,7 & 1,6 & 1,1 \\
\hline Plough & 4,3 & 6,9 & 7,9 & 7,4 & 7,7 & 7,3 & 4,1 & 3,6 & 2,4 & 3,1 & 5,5 \\
\hline Tractor & 0,9 & 1,3 & 1,5 & 1,0 & 0,9 & 1,6 & 0,8 & 0,9 & 1,6 & 3,2 & 1,4 \\
\hline Wheelbarrow & 26,7 & 33,4 & 35,0 & 38,0 & 34,3 & 32,6 & 28,1 & 28,7 & 33,5 & 48,2 & 33,8 \\
\hline Grinding mill & 1,4 & 2,2 & 2,2 & 2,0 & 2,4 & 2,2 & 1,4 & 1,6 & 3,8 & 5,7 & 2,5 \\
\hline Bicycle & 7,8 & 9,0 & 9,6 & 11,7 & 12,7 & 13,1 & 12,5 & 15,6 & 26,8 & 42,7 & 16,2 \\
\hline Computer & 1,3 & 1,8 & 1,3 & 1,6 & 2,4 & 3,9 & 8,0 & 15,6 & 39,6 & 71,3 & 14,7 \\
\hline Canoe/boat & 0,1 & 0,2 & 0,3 & 0,4 & 0,4 & 0,1 & 0,6 & 0,2 & 2,1 & 6,4 & 1,1 \\
\hline Motorboat & & 0,2 & 0,2 & 0,1 & 0,3 & 0,3 & 0,2 & 0,3 & 0,9 & 4,8 & 0,7 \\
\hline Camera & 3,9 & 4,6 & 4,5 & 6,3 & 6,8 & 10,1 & 13,1 & 20,1 & 45,1 & 76,5 & 19,1 \\
\hline Bed & 95,5 & 95,9 & 96,3 & 96,7 & 97,8 & 98,1 & 98,3 & 98,3 & 99,3 & 99,9 & 97,6 \\
\hline Cellular telephone & 43,7 & 50,1 & 60,3 & 64,9 & 66,7 & 72,0 & 76,6 & 82,4 & 91,9 & 95,1 & 70,4 \\
\hline Landline telephone & 5,5 & 6,5 & 8,2 & 8,9 & 12,4 & 13,4 & 19,7 & 28,7 & 44,5 & 72,7 & 22,0 \\
\hline Satellite dish & 0,3 & 0,9 & 0,9 & 0,7 & 0,6 & 1,3 & 1,6 & 3,4 & 10,2 & 36,5 & 5,7 \\
\hline Internet service & 0,4 & 0,8 & 0,3 & 1,0 & 0,9 & 1,6 & 2,5 & 5,2 & 12,9 & 39,4 & 6,5 \\
\hline
\end{tabular}

Due to rounding, figures do not necessarily add up to totals

- No respondents 


\section{Ownership of assets}

Table 4.3 - Ownership of assets by household type of settlement

\begin{tabular}{|c|c|c|c|}
\hline & Urban & Rural & Total \\
\hline Number of households in sample & 11859 & 9285 & 21144 \\
\hline Number of households in population & 8112493 & 4345088 & 12457581 \\
\hline Own or have access to & \multicolumn{3}{|c|}{ Percentage of total in each column } \\
\hline Radio & 75,8 & 73,5 & 75,0 \\
\hline Stereo/HiFi & 49,9 & 26,1 & 41,6 \\
\hline Tape recorder & 39,1 & 28,1 & 35,3 \\
\hline Television & 76,9 & 47,4 & 66,6 \\
\hline Video cassette recorder/DVD & 47,1 & 14,1 & 35,6 \\
\hline Refrigerator/freezer & 73,8 & 45,0 & 63,7 \\
\hline Stove, gas or electric & 88,2 & 60,5 & 78,6 \\
\hline Microwave & 45,4 & 8,7 & 32,6 \\
\hline Washing machine & 34,4 & 10,6 & 26,1 \\
\hline Motor vehicle & 25,6 & 3,3 & 17,8 \\
\hline Motorcycle/scooter & 2,6 & 0,6 & 1,9 \\
\hline Sewing/knitting machine & 12,8 & 8,2 & 11,2 \\
\hline Donkey cart/ox cart & 0,5 & 2,4 & 1,1 \\
\hline Plough & 1,3 & 13,2 & 5,5 \\
\hline Tractor & 0,5 & 2,9 & 1,4 \\
\hline Wheelbarrow & 23,8 & 52,5 & 33,8 \\
\hline Grinding mill & 1,8 & 3,8 & 2,5 \\
\hline Bicycle & 17,5 & 13,6 & 16,2 \\
\hline Computer & 20,8 & 3,2 & 14,7 \\
\hline Canoe/boat & 1,5 & 0,4 & 1,1 \\
\hline Motorboat & 1,0 & 0,2 & 0,7 \\
\hline Camera & 25,8 & 6,7 & 19,1 \\
\hline Bed & 98,4 & 96,0 & 97,6 \\
\hline Cellular telephone & 74,3 & 63,0 & 70,4 \\
\hline Landline telephone & 30,9 & 5,4 & 22,0 \\
\hline Satellite dish & 8,0 & 1,2 & 5,7 \\
\hline Internet service & 9,6 & 0,7 & 6,5 \\
\hline
\end{tabular}

Due to rounding, figures do not necessarily add up to totals 


\section{Ownership of assets}

Table 4.4 - Ownership of assets by population group of household head

\begin{tabular}{|c|c|c|c|c|c|c|}
\hline & Black African & Coloured & \begin{tabular}{r|} 
Indian/ \\
Asian
\end{tabular} & White & Unspecified & Total \\
\hline Number of households in sample & 16110 & 2691 & 348 & 1974 & 21 & 21144 \\
\hline Number of households in population & 9566382 & 965778 & 310652 & 1596888 & 17881 & 12457581 \\
\hline Own or have access to & \multicolumn{6}{|c|}{ Percentage of total in each column } \\
\hline Radio & 72,5 & 75,6 & 79,4 & 88,8 & 69,4 & 75,0 \\
\hline Stereo/HiFi & 33,2 & 55,9 & 64,3 & 78,5 & 90,4 & 41,6 \\
\hline Tape recorder & 29,2 & 50,3 & 38,2 & 61,8 & 47,1 & 35,3 \\
\hline Television & 58,6 & 85,7 & 92,5 & 97,8 & 86,4 & 66,6 \\
\hline Video cassette recorder/DVD & 24,3 & 53,8 & 82,8 & 82,7 & 69,2 & 35,6 \\
\hline Refrigerator/ freezer & 54,8 & 83,4 & 96,5 & 99,0 & 79,6 & 63,7 \\
\hline Stove, gas or electric & 72,9 & 94,4 & 98,3 & 98,8 & 93,9 & 78,6 \\
\hline Microwave & 18,5 & 53,3 & 86,9 & 93,6 & 60,6 & 32,6 \\
\hline Washing machine & 13,0 & 32,8 & 65,7 & 92,5 & 56,7 & 26,1 \\
\hline Motor vehicle & 5,0 & 26,1 & 44,7 & 84,1 & 53,1 & 17,8 \\
\hline Motorcycle/scooter & 0,3 & 1,5 & 5,4 & 10,4 & 2,0 & 1,9 \\
\hline Sewing/knitting machine & 6,6 & 10,3 & 15,5 & 38,3 & 14,5 & 11,2 \\
\hline Donkey cart/ox cart & 1,1 & 1,0 & 0,6 & 1,6 & - & 1,1 \\
\hline Plough & 6,5 & 0,6 & 1,1 & 3,2 & - & 5,5 \\
\hline Tractor & 1,1 & 0,7 & 0,5 & 3,6 & - & 1,4 \\
\hline Wheelbarrow & 34,7 & 13,5 & 16,0 & 44,5 & 22,1 & 33,8 \\
\hline Grinding mill & 2,0 & 1,7 & 2,1 & 6,3 & - & 2,5 \\
\hline Bicycle & 11,6 & 22,1 & 16,6 & 40,0 & 6,6 & 16,2 \\
\hline Computer & 5,0 & 18,5 & 36,6 & 65,8 & 39,2 & 14,7 \\
\hline Canoe/boat & 0,2 & 0,3 & 1,1 & 6,8 & 4,6 & 1,1 \\
\hline Motorboat & 0,2 & 0,5 & 1,1 & 4,0 & & 0,7 \\
\hline Camera & 8,8 & 27,5 & 35,1 & 72,2 & 50,4 & 19,1 \\
\hline Bed & 97,1 & 98,8 & 99,6 & 99,8 & 100,0 & 97,6 \\
\hline Cellular telephone & 67,7 & 63,3 & 78,9 & 89,1 & 75,5 & 70,4 \\
\hline Landline telephone & 10,9 & 42,5 & 60,5 & 68,7 & 39,0 & 22,0 \\
\hline Satellite dish & 1,6 & 4,9 & 12,3 & 29,1 & 27,3 & 5,7 \\
\hline Internet service & 1,7 & 4,4 & 10,6 & 35,8 & 27,6 & 6,5 \\
\hline
\end{tabular}

Due to rounding, figures do not necessarily add up to totals

- No respondents 
4. Ownership of assets

Table 4.5 - Ownership of assets by province

\begin{tabular}{|c|c|c|c|c|c|c|c|c|c|c|}
\hline & $\begin{array}{r}\text { Western } \\
\text { Cape }\end{array}$ & $\begin{array}{r}\text { Eastern } \\
\text { Cape }\end{array}$ & $\begin{array}{r}\text { Northern } \\
\text { Cape }\end{array}$ & Free State & \begin{tabular}{r|} 
KwaZulu- \\
Natal
\end{tabular} & \begin{tabular}{c|} 
North \\
West
\end{tabular} & Gauteng & Mpumalanga & Limpopo & Total \\
\hline Number of households in sample & 2404 & 2825 & 1726 & 1754 & 4732 & 1569 & 2496 & 1687 & 1951 & 21144 \\
\hline Number of households in population & 1271541 & 1723789 & 293306 & 899152 & 2214405 & 907475 & 2967693 & 879707 & 1300512 & 12457580 \\
\hline Own or have access to & \multicolumn{10}{|c|}{ Percentage of total in each column } \\
\hline Radio & 79,6 & 71,0 & 72,7 & 83,1 & 74,9 & 75,4 & 72,9 & 78,9 & 72,7 & 75,0 \\
\hline Stereo/HiFi & 62,1 & 32,8 & 45,4 & 53,5 & 33,0 & 35,3 & 47,5 & 38,1 & 32,0 & 41,6 \\
\hline Tape recorder & 55,8 & 23,0 & 43,8 & 56,4 & 22,5 & 39,7 & 30,9 & 40,4 & 40,3 & 35,3 \\
\hline Television & 82,8 & 55,4 & 69,0 & 71,1 & 59,3 & 71,2 & 75,5 & 63,5 & 53,3 & 66,6 \\
\hline Video cassette recorder/DVD & 53,4 & 21,4 & 29,0 & 32,9 & 31,1 & 32,1 & 50,3 & 28,8 & 21,4 & 35,6 \\
\hline Refrigerator/ freezer & 82,7 & 46,1 & 66,5 & 65,8 & 59,4 & 64,2 & 71,0 & 64,1 & 56,6 & 63,7 \\
\hline Stove, gas or electric & 92,9 & 78,1 & 83,9 & 85,3 & 72,5 & 76,5 & 86,5 & 74,6 & 55,9 & 78,6 \\
\hline Microwave & 59,2 & 21,4 & 27,0 & 33,6 & 27,8 & 26,1 & 44,8 & 24,2 & 12,4 & 32,6 \\
\hline Washing machine & 42,7 & 17,3 & 25,1 & 22,6 & 19,5 & 25,2 & 36,7 & 20,5 & 15,2 & 26,1 \\
\hline Motor vehicle & 37,8 & 11,4 & 16,6 & 14,6 & 11,4 & 17,1 & 27,2 & 10,0 & 4,6 & 17,8 \\
\hline Motorcycle/scooter & 2,8 & 0,8 & 2,2 & 2,6 & 1,0 & 1,1 & 3,5 & 0,9 & 0,7 & 1,9 \\
\hline Sewing/knitting machine & 17,4 & 8,8 & 12,0 & 15,9 & 9,9 & 10,5 & 10,4 & 11,4 & 9,4 & 11,2 \\
\hline Donkey cart/ox cart & 0,5 & 1,3 & 6,0 & 0,7 & 0,6 & 2,6 & 0,7 & 1,1 & 1,8 & 1,1 \\
\hline Plough & 0,8 & 10,4 & 2,7 & 1,5 & 10,6 & 1,9 & 0,7 & 4,4 & 12,3 & 5,5 \\
\hline Tractor & 0,8 & 2,0 & 2,8 & 1,5 & 0,7 & 0,9 & 0,9 & 1,9 & 2,7 & 1,4 \\
\hline Wheelbarrow & 12,5 & 37,2 & 29,8 & 32,1 & 27,0 & 52,9 & 23,4 & 51,2 & 62,8 & 33,8 \\
\hline Grinding mill & 0,8 & 3,3 & 2,0 & 5,4 & 1,9 & 1,3 & 2,1 & 2,5 & 3,9 & 2,5 \\
\hline Bicycle & 25,6 & 9,9 & 21,5 & 20,8 & 9,2 & 26,3 & 16,9 & 14,6 & 14,9 & 16,2 \\
\hline Computer & 29,0 & 8,5 & 9,9 & 12,7 & 10,8 & 13,4 & 21,3 & 10,1 & 6,6 & 14,7 \\
\hline Canoe/boat & 2,2 & 0,7 & 0,6 & 0,7 & 0,8 & 0,4 & 1,8 & 0,8 & 0,3 & 1,1 \\
\hline Motorboat & 1,0 & 0,7 & 0,5 & 0,2 & 0,5 & 0,1 & 1,6 & 0,3 & 0,2 & 0,7 \\
\hline Camera & 37,7 & 12,7 & 16,5 & 17,5 & 14,2 & 14,3 & 26,0 & 16,0 & 9,3 & 19,1 \\
\hline Bed & 99,0 & 97,8 & 97,1 & 98,4 & 96,8 & 97,7 & 98,0 & 98,1 & 95,5 & 97,6 \\
\hline Cellular telephone & 73,5 & 63,4 & 60,6 & 69,7 & 69,4 & 73,1 & 73,9 & 74,0 & 68,5 & 70,4 \\
\hline Landline telephone & 43,2 & 17,5 & 25,1 & 23,1 & 18,7 & 18,8 & 29,0 & 11,6 & 4,8 & 22,0 \\
\hline Satellite dish & 12,9 & 2,9 & 4,3 & 5,3 & 3,6 & 3,5 & 8,9 & 3,1 & 2,0 & 5,7 \\
\hline Internet service & 13,9 & 3,7 & 3,4 & 4,5 & 4,4 & 5,5 & 10,6 & 4,6 & 1,4 & 6,5 \\
\hline
\end{tabular}

Due to rounding, figures do not necessarily add up to totals 


\section{Household characteristics}

Table 5.1 - Number of households by ownership of dwelling and income deciles

\begin{tabular}{|c|c|c|c|c|c|c|c|c|c|c|c|}
\hline \multirow[t]{3}{*}{ Ownership of dwelling } & \multicolumn{11}{|c|}{$\mathrm{N}(\mathbf{1 0 0 0 )}$} \\
\hline & \multicolumn{10}{|c|}{ Income deciles } & \multirow[t]{2}{*}{ Total } \\
\hline & Lower & 2 & 3 & 4 & 5 & 6 & 7 & 8 & 9 & Upper & \\
\hline Owned and fully paid off & 863 & 909 & 949 & 932 & 899 & 873 & 755 & 738 & 556 & 367 & 7840 \\
\hline Owned but not yet fully paid off & * & 11 & * & 16 & * & 21 & 53 & 119 & 281 & 702 & 1224 \\
\hline Rented as part of employment & 14 & 23 & 33 & 28 & 28 & 37 & 64 & 68 & 102 & 29 & 426 \\
\hline Rented not as part of employment & 172 & 151 & 136 & 140 & 189 & 189 & 245 & 244 & 257 & 129 & 1851 \\
\hline Occupied rent-free as part of employment & 52 & 69 & 64 & 62 & 61 & 84 & 74 & 44 & 17 & 11 & 539 \\
\hline Occupied rent-free not as part of employment & 118 & 69 & 46 & 50 & 48 & 39 & 39 & 26 & 21 & * & 462 \\
\hline Other & 20 & 14 & 12 & 17 & 13 & & 15 & & 11 & * & 115 \\
\hline Total & 1246 & 1246 & 1246 & 1246 & 1246 & 1245 & 1246 & 1245 & 1247 & 1246 & 12458 \\
\hline
\end{tabular}

*For all values of 10000 or lower the sample size is too small for reliable estimates

Due to rounding figures do not necessarily add up to totals 


\section{Household characteristics}

Table 5.2 - Number of households by main source of energy and income deciles

\begin{tabular}{|c|c|c|c|c|c|c|c|c|c|c|c|}
\hline \multirow[t]{3}{*}{ Source of energy } & \multicolumn{11}{|c|}{$N(1000)$} \\
\hline & \multicolumn{10}{|c|}{ Income deciles } & \multirow[t]{2}{*}{ Total } \\
\hline & Lower & 2 & 3 & 4 & 5 & 6 & 7 & 8 & 9 & Upper & \\
\hline Energy for cooking - Total & 1245 & 1245 & 1247 & 1246 & 1246 & 1246 & 1246 & 1245 & 1247 & 1246 & 12458 \\
\hline Electricity & 447 & 467 & 524 & 546 & 672 & 735 & 895 & 1034 & 1157 & 1181 & 7659 \\
\hline Paraffin & 438 & 387 & 340 & 362 & 275 & 256 & 205 & 115 & 22 & * & 2401 \\
\hline Wood & 288 & 330 & 292 & 275 & 222 & 151 & 75 & 39 & 21 & $*$ & 1696 \\
\hline Coal & 15 & 28 & 40 & 22 & 32 & 32 & 22 & 15 & & $*$ & 217 \\
\hline Other & $*$ & * & $*$ & $*$ & * & $\star$ & - & $\star$ & - & - & 34 \\
\hline None & 35 & * & 10 & * & 9 & 12 & $*$ & $\star$ & * & 11 & 102 \\
\hline Missing information & - & * & * & * & * & - & $*$ & * & * & * & 23 \\
\hline Energy for heating - Total & 1245 & 1245 & 1247 & 1246 & 1246 & 1246 & 1246 & 1245 & 1247 & 1246 & 12458 \\
\hline Electricity & 326 & 305 & 360 & 380 & 460 & 553 & 736 & 835 & 1022 & 1081 & 6057 \\
\hline Paraffin & 237 & 210 & 194 & 223 & 191 & 194 & 147 & 160 & 64 & 24 & 1644 \\
\hline Wood & 384 & 444 & 402 & 391 & 316 & 210 & 127 & 65 & 31 & 22 & 2393 \\
\hline Coal & 51 & 70 & 93 & 57 & 74 & 81 & 68 & 39 & 12 & $*$ & 550 \\
\hline Other & * & * & * & * & * & $*$ & $*$ & - & * & - & 50 \\
\hline None & 223 & 198 & 182 & 178 & 192 & 197 & 153 & 132 & 79 & 50 & 1583 \\
\hline Missing information & & & & & & $*$ & & & * & $*$ & 42 \\
\hline Energy for lighting - Total & 1245 & 1245 & 1247 & 1246 & 1246 & 1246 & 1246 & 1245 & 1247 & 1246 & 12458 \\
\hline Electricity & 778 & 818 & 888 & 915 & 974 & 998 & 1076 & $\begin{array}{lll}1 & 147\end{array}$ & 1218 & 1227 & 10040 \\
\hline Paraffin & 103 & 89 & 79 & 83 & 64 & 60 & 43 & 31 & 13 & 11 & 576 \\
\hline Candles & 349 & 326 & 265 & 238 & 194 & 178 & 116 & 58 & 14 & * & 1739 \\
\hline Other & * & * & 11 & * & * & * & * & * & - & * & 50 \\
\hline Missing information & $\star$ & * & * & * & * & $*$ & $\star$ & * & * & $*$ & 52 \\
\hline
\end{tabular}

${ }^{*}$ For all values of 10000 or lower the sample size is too small for reliable estimates

Due to rounding, figures do not necessarily add up to totals 


\section{Household characteristics}

Table 5.3 - Number of households by main source of water and income deciles

\begin{tabular}{|c|c|c|c|c|c|c|c|c|c|c|c|}
\hline \multirow[t]{3}{*}{ Main source of water } & \multicolumn{11}{|c|}{$\mathrm{N}(\mathbf{1 0 0 0 )}$} \\
\hline & \multicolumn{10}{|c|}{ Income deciles } & \multirow[t]{2}{*}{ Total } \\
\hline & Upper & 2 & 3 & 4 & 5 & 6 & 7 & 8 & 9 & Lower & \\
\hline Piped water in dwelling & 189 & 212 & 249 & 267 & 332 & 386 & 533 & 764 & 1037 & 1176 & 5146 \\
\hline Borehole on site & * & 21 & 14 & 10 & 21 & 24 & 17 & 13 & 14 & 16 & 153 \\
\hline Rainwater tank on site & 26 & 11 & 11 & 15 & 18 & 15 & 14 & 13 & 11 & 14 & 147 \\
\hline Neighbour's tap & 362 & 347 & 291 & 291 & 235 & 210 & 157 & 107 & 28 & * & 2029 \\
\hline Public tap & 17 & 25 & 22 & 20 & 18 & 18 & 12 & * & * & * & 148 \\
\hline Water-carrier/tanker & 46 & 48 & 70 & 46 & 37 & 35 & 20 & * & * & * & 319 \\
\hline Borehole off site & 68 & 61 & 66 & 57 & 56 & 35 & 13 & * & * & * & 368 \\
\hline Well & 57 & 51 & 57 & 50 & 25 & 23 & 11 & * & * & * & 287 \\
\hline Other & 17 & 21 & 28 & 24 & 18 & 14 & $*$ & * & * & * & 146 \\
\hline Total & 1245 & 1245 & 1247 & 1246 & 1246 & 1246 & 1246 & 1245 & 1247 & 1246 & 12458 \\
\hline
\end{tabular}

*For all values of 10000 or lower the sample size is too small for reliable estimates

Due to rounding, figures do not necessarily add up to totals 


\section{Household characteristics}

Table 5.4 - Number of households by type of dwelling and income deciles

\begin{tabular}{|c|c|c|c|c|c|c|c|c|c|c|c|}
\hline \multirow[t]{3}{*}{ Type of dwelling } & \multicolumn{11}{|c|}{$\mathrm{N}(1000)$} \\
\hline & \multicolumn{10}{|c|}{ Income deciles } & \multirow[t]{2}{*}{ Total } \\
\hline & Lower & 2 & 3 & 4 & 5 & 6 & 7 & 8 & 9 & Upper & \\
\hline Dwelling on a separate stand/yard/farm & 501 & 579 & 692 & 686 & 681 & 672 & 685 & 815 & 917 & 1049 & 7277 \\
\hline Traditional dwelling & 272 & 266 & 219 & 215 & 172 & 125 & 57 & 38 & 19 & * & 1387 \\
\hline Flat or apartment & 21 & 36 & 23 & 28 & 46 & 46 & 78 & 111 & 160 & 66 & 614 \\
\hline Townhouse & * & 11 & 13 & 17 & 19 & 25 & 43 & 46 & 75 & 110 & 364 \\
\hline Dwelling in backyard & 26 & 19 & 18 & 25 & 43 & 43 & 31 & 26 & 13 & * & 249 \\
\hline Informal dwelling in backyard & 86 & 55 & 58 & 50 & 43 & 54 & 42 & 29 & 10 & - & 426 \\
\hline Informal dwelling not in backyard & 231 & 193 & 156 & 156 & 159 & 176 & 164 & 84 & 16 & * & 1340 \\
\hline Room or flatlet & 29 & 38 & 32 & 35 & 32 & 25 & 43 & 35 & 22 & * & 295 \\
\hline Other & 72 & 49 & 35 & 33 & 51 & 80 & 105 & 60 & 17 & $*$ & 506 \\
\hline Total & 1245 & 1245 & 1247 & 1246 & 1246 & 1246 & 1246 & 1245 & 1247 & 1246 & 12458 \\
\hline
\end{tabular}

*For all values of 10000 or lower the sample size is too small for reliable estimates

Due to rounding, figures do not necessarily add up to totals 


\section{Household characteristics}

Table 5.5 - Number of households by sanitation facility and income deciles

\begin{tabular}{|c|c|c|c|c|c|c|c|c|c|c|c|}
\hline \multirow[t]{3}{*}{ Sanitation facility } & \multicolumn{11}{|c|}{ N (1000) } \\
\hline & \multicolumn{10}{|c|}{ Income deciles } & \multirow[t]{2}{*}{ Total } \\
\hline & Lower & 2 & 3 & 4 & 5 & 6 & 7 & 8 & 9 & Upper & \\
\hline \multicolumn{12}{|l|}{ Sanitation in dwelling } \\
\hline Total & 169 & 179 & 205 & 229 & 265 & 316 & 457 & 687 & 1020 & 1177 & 4705 \\
\hline Flush toilet with off-site disposal & 157 & 170 & 192 & 207 & 249 & 294 & 440 & 654 & 980 & 1143 & 4486 \\
\hline Flush toilet with on-site disposal & 12 & 10 & 13 & 22 & 16 & 22 & 17 & 33 & 40 & 34 & 218 \\
\hline \multicolumn{12}{|l|}{ Sanitation on site } \\
\hline Total & 777 & 775 & 829 & 813 & 823 & 789 & 695 & 512 & 215 & 55 & 6282 \\
\hline Flush toilet with off-site disposal & 226 & 211 & 206 & 232 & 270 & 327 & 361 & 227 & 103 & 26 & 2189 \\
\hline Flush toilet with on-site disposal & 20 & 15 & 24 & 22 & 27 & 30 & 28 & 25 & 10 & * & 205 \\
\hline Chemical toilet & & * & * & * & * & 10 & * & * & * & - & 54 \\
\hline Pit latrine with ventilation pipe & 130 & 132 & 140 & 146 & 123 & 92 & 64 & 63 & 32 & * & 929 \\
\hline Pit latrine without ventilation pipe & 340 & 360 & 410 & 367 & 359 & 305 & 218 & 179 & 65 & 18 & 2621 \\
\hline Bucket toilet & 57 & 51 & 41 & 42 & 37 & 24 & 18 & 10 & $*$ & - & 283 \\
\hline \multicolumn{12}{|l|}{ Sanitation off site } \\
\hline Total & 299 & 291 & 213 & 204 & 157 & 141 & 94 & 46 & 12 & 14 & 1471 \\
\hline Flush toilet with off-site disposal & & & * & * & 18 & 19 & 20 & * & $*$ & * & 102 \\
\hline Flush toilet with on-site disposal & & * & * & * & & * & * & * & & & 16 \\
\hline Chemical toilet & $\star$ & * & * & * & * & * & * & * & - & 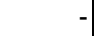 & 39 \\
\hline Pit latrine with ventilation pipe & 11 & 11 & * & * & * & 10 & * & * & - & - & 63 \\
\hline Pit latrine without ventilation pipe & 27 & 36 & 30 & 25 & 25 & 19 & 18 & 10 & * & - & 192 \\
\hline Bucket toilet & & 11 & * & 11 & $*$ & * & * & * & - & - & 46 \\
\hline None & 237 & 217 & 158 & 145 & 95 & 76 & 42 & 18 & * & 12 & 1008 \\
\hline Missing information & & & & & & & & & & & \\
\hline Total & 1245 & 1245 & 1247 & 1246 & 1246 & 1246 & 1246 & 1245 & 1247 & 1245 & 12457 \\
\hline
\end{tabular}

Due to rounding, figures do not necessarily add up to totals

*For all values of 10000 or lower the sample size is too small for reliable estimates

- No respondents 


\section{Household characteristics}

\section{Table 5.6 - Number of households by type of refuse removal and income deciles}

\begin{tabular}{|c|c|c|c|c|c|c|c|c|c|c|c|}
\hline \multirow[t]{3}{*}{ Refuse removal } & \multicolumn{11}{|c|}{$\mathrm{N}(\mathbf{1 0 0 0 )}$} \\
\hline & \multicolumn{10}{|c|}{ Income deciles } & \multirow[t]{2}{*}{ Tota } \\
\hline & Lower & 2 & 3 & 4 & 5 & 6 & 7 & 8 & 9 & Upper & \\
\hline Local authority at least once a week & 469 & 456 & 480 & 522 & 601 & 715 & 812 & 902 & 1069 & 1146 & 7173 \\
\hline Local authority less than once a week & 21 & 23 & 24 & 24 & 33 & 30 & 35 & 31 & 31 & 11 & 261 \\
\hline Community members at least once a week & * & * & * & * & * & * & * & * & * & * & 41 \\
\hline Community members less than once a week & * & * & * & * & * & * & $*$ & * & * & * & 22 \\
\hline Communal refuse dump/communal container & 29 & 40 & 47 & 38 & 41 & 50 & 69 & 31 & * & * & 356 \\
\hline Own refuse dump & 601 & 616 & 600 & 566 & 474 & 381 & 273 & 233 & 121 & 58 & 3924 \\
\hline No rubbish removal & 112 & 86 & 85 & 76 & 76 & 52 & 33 & 27 & * & * & 562 \\
\hline Other & & 10 & * & * & * & * & 15 & * & * & 12 & 88 \\
\hline Missing information & & & & * & $\star$ & * & & * & * & * & 30 \\
\hline Total & 1245 & 1245 & 1247 & 1246 & 1246 & 1246 & 1246 & 1245 & 1247 & 1246 & 12458 \\
\hline
\end{tabular}

For all values of 10000 or lower the sample size is too small for reliable estimates

Due to rounding, figures do not necessarily add up to totals 
Figure A1 - Proportion of total household expenditure on food and alcoholic beverages by population group of household head

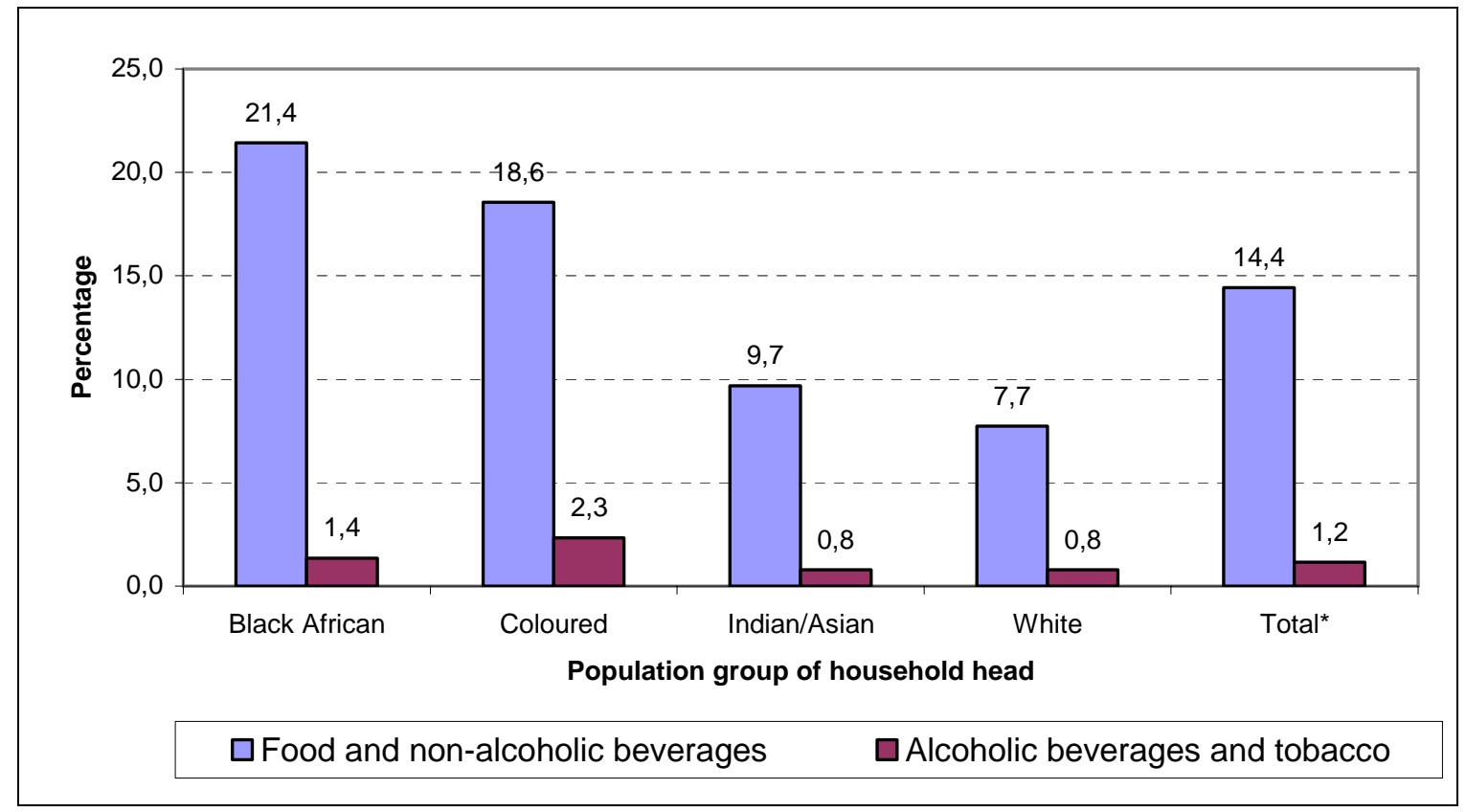

Total* includes households with unspecified population group of household head

Figure A2 - Proportion of total household expenditure on food and beverages by sex of household head

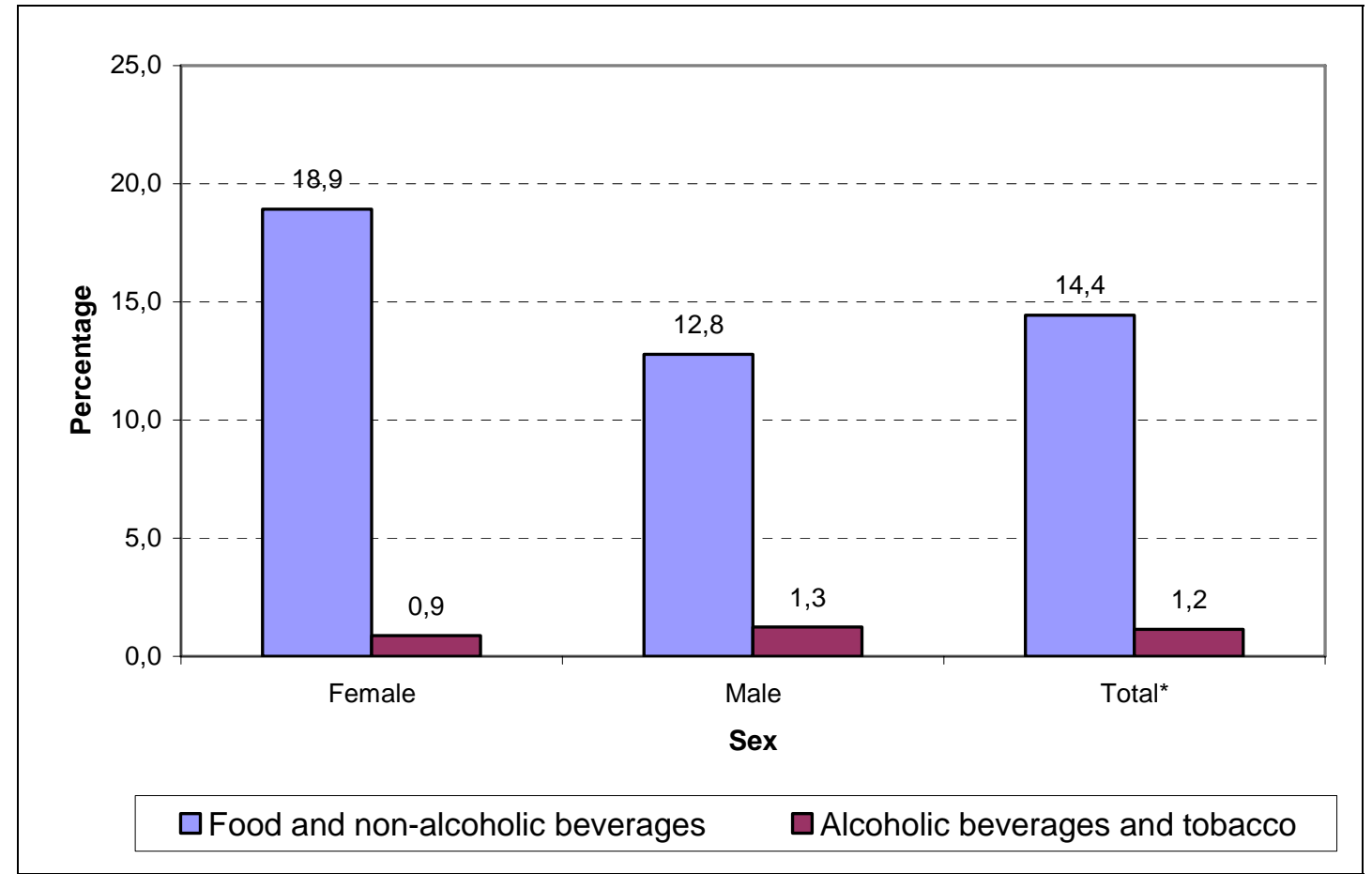

Total* includes households with unspecified sex of household head 
Figure A3 - Proportion of total household expenditure on food and alcoholic beverages by settlement type

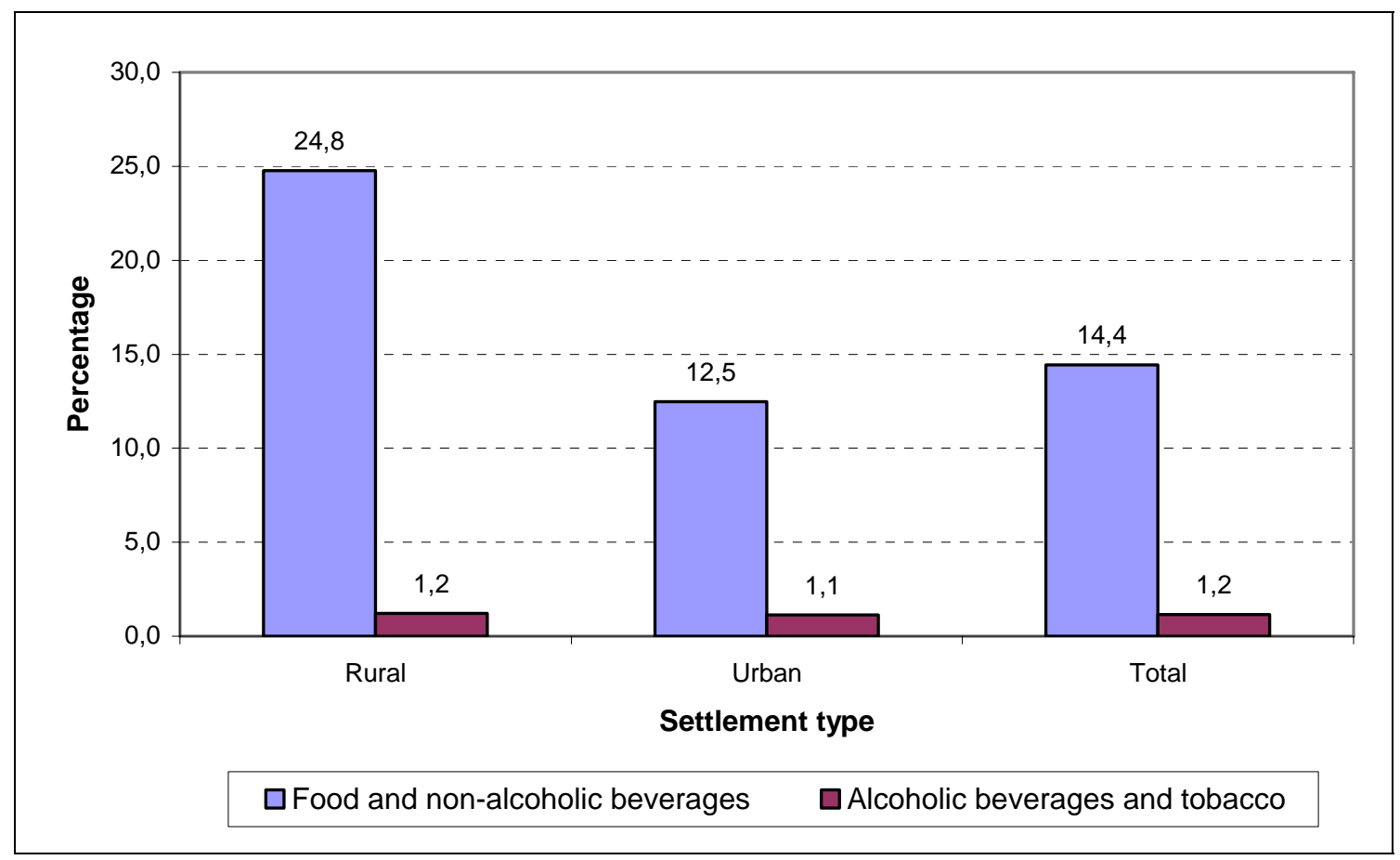

Figure A4 - Proportion of total household expenditure on food and beverages by province

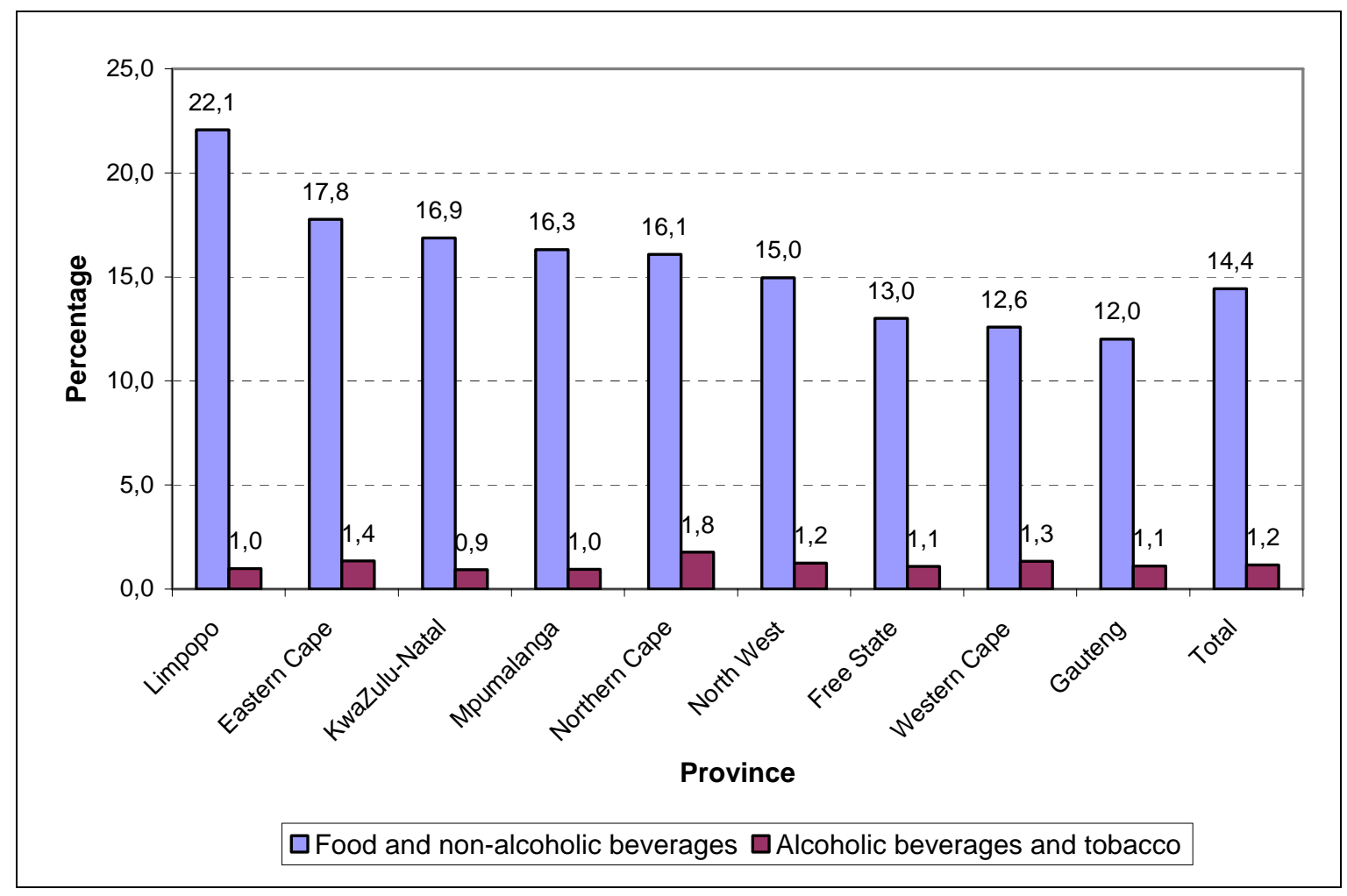


Figure B1 - Proportion of total household expenditure on clothing and footwear by population group of household head

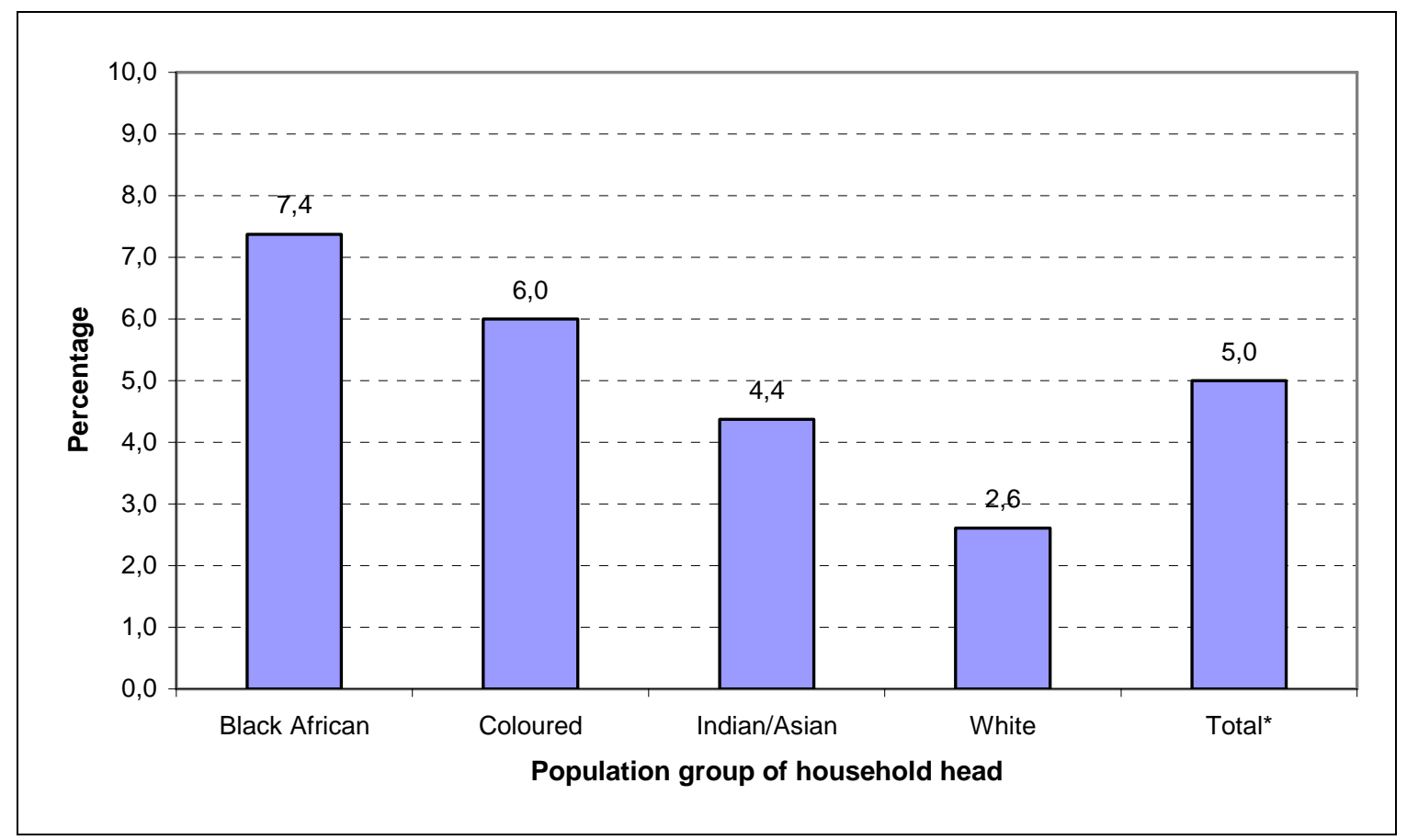

Total* includes households with unspecified population group of household head

Figure B2 - Proportion of total household expenditure on clothing and footwear by sex of household head

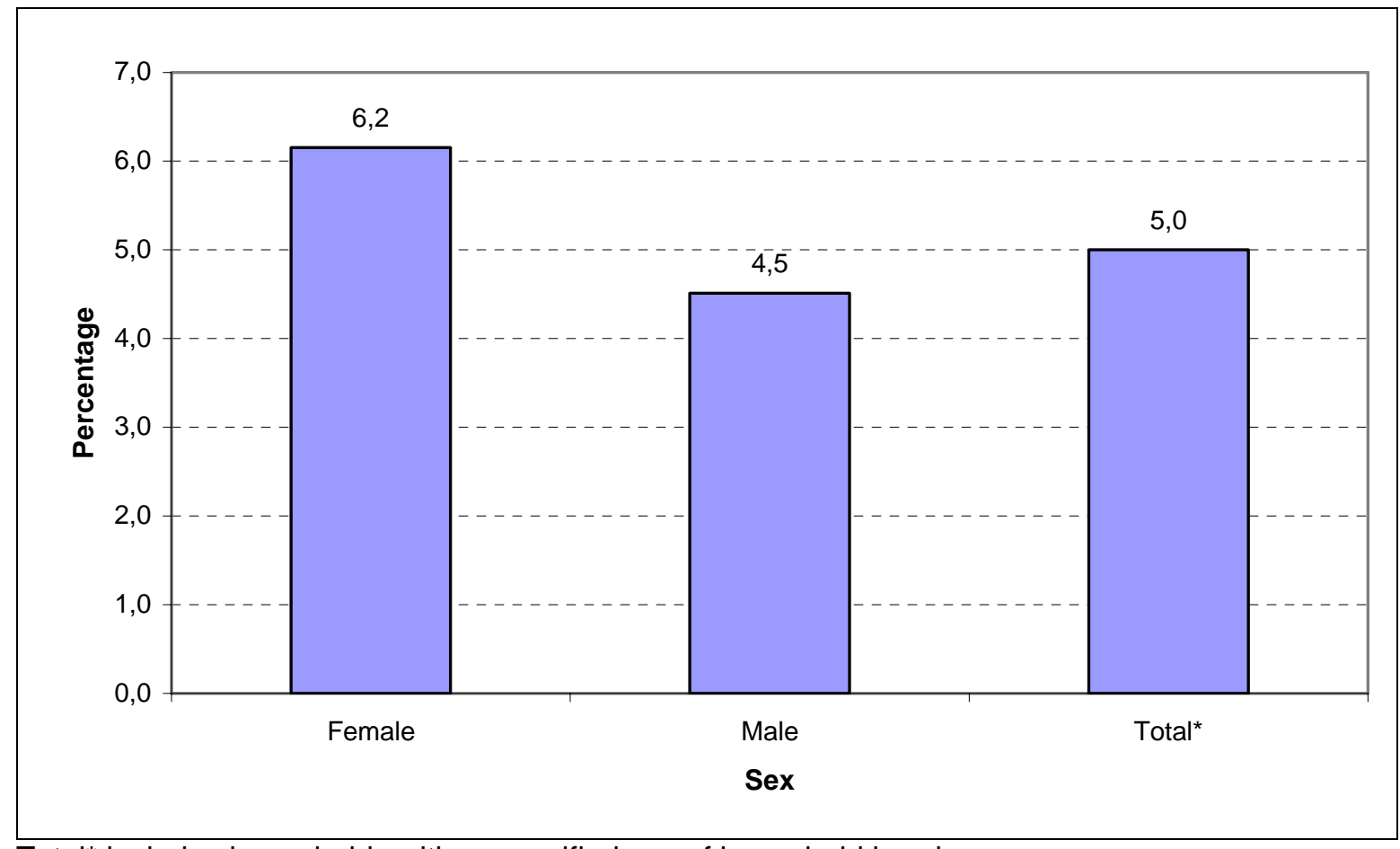

Total $^{*}$ includes households with unspecified sex of household head 
Figure B3 - Proportion of total household expenditure on clothing and footwear by settlement type

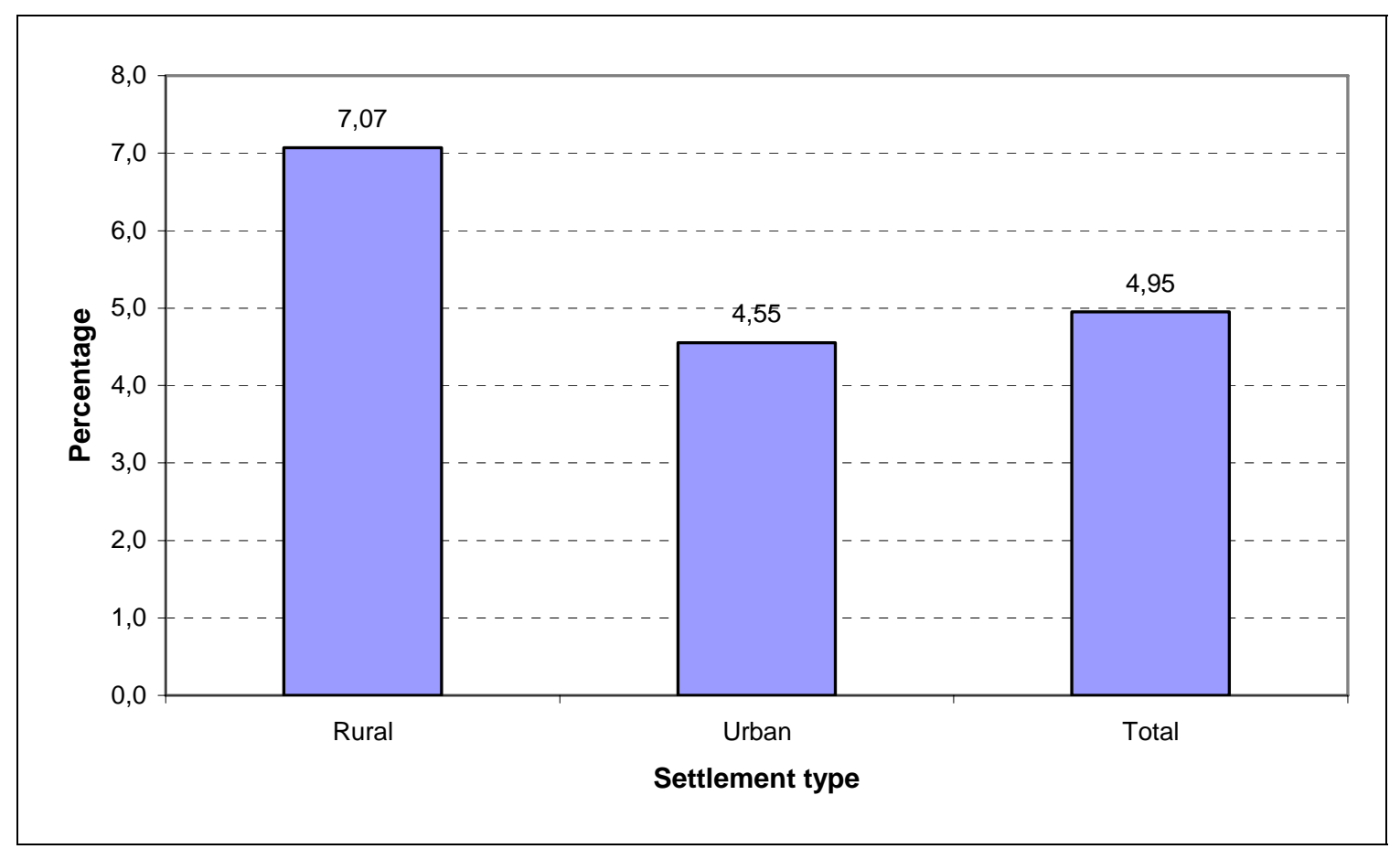

Figure B4 - Proportion of total household expenditure on clothing and footwear by province

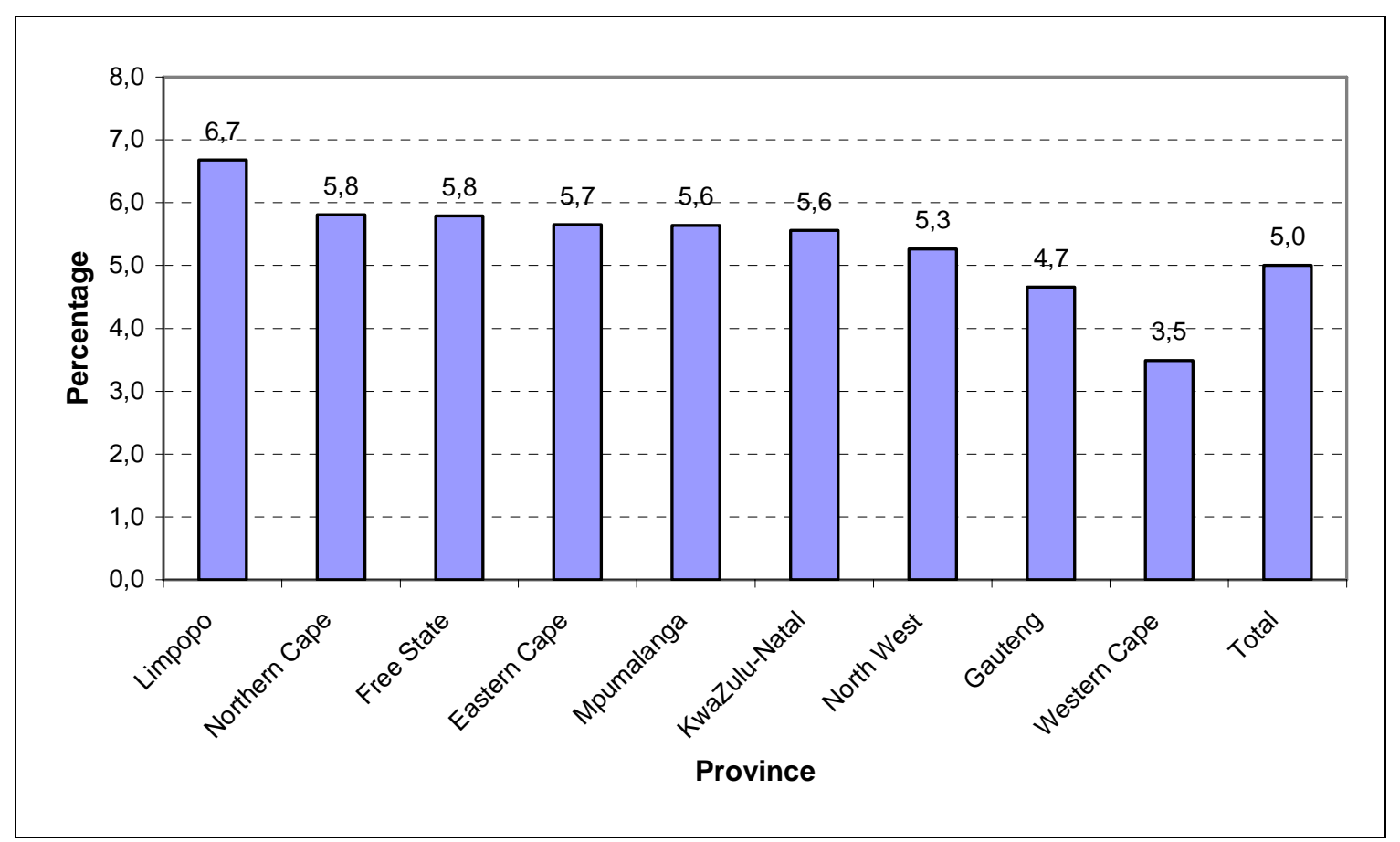


Figure C1 - Proportion of total household expenditure on housing, water, electricity, gas and other fuels by population group of household head

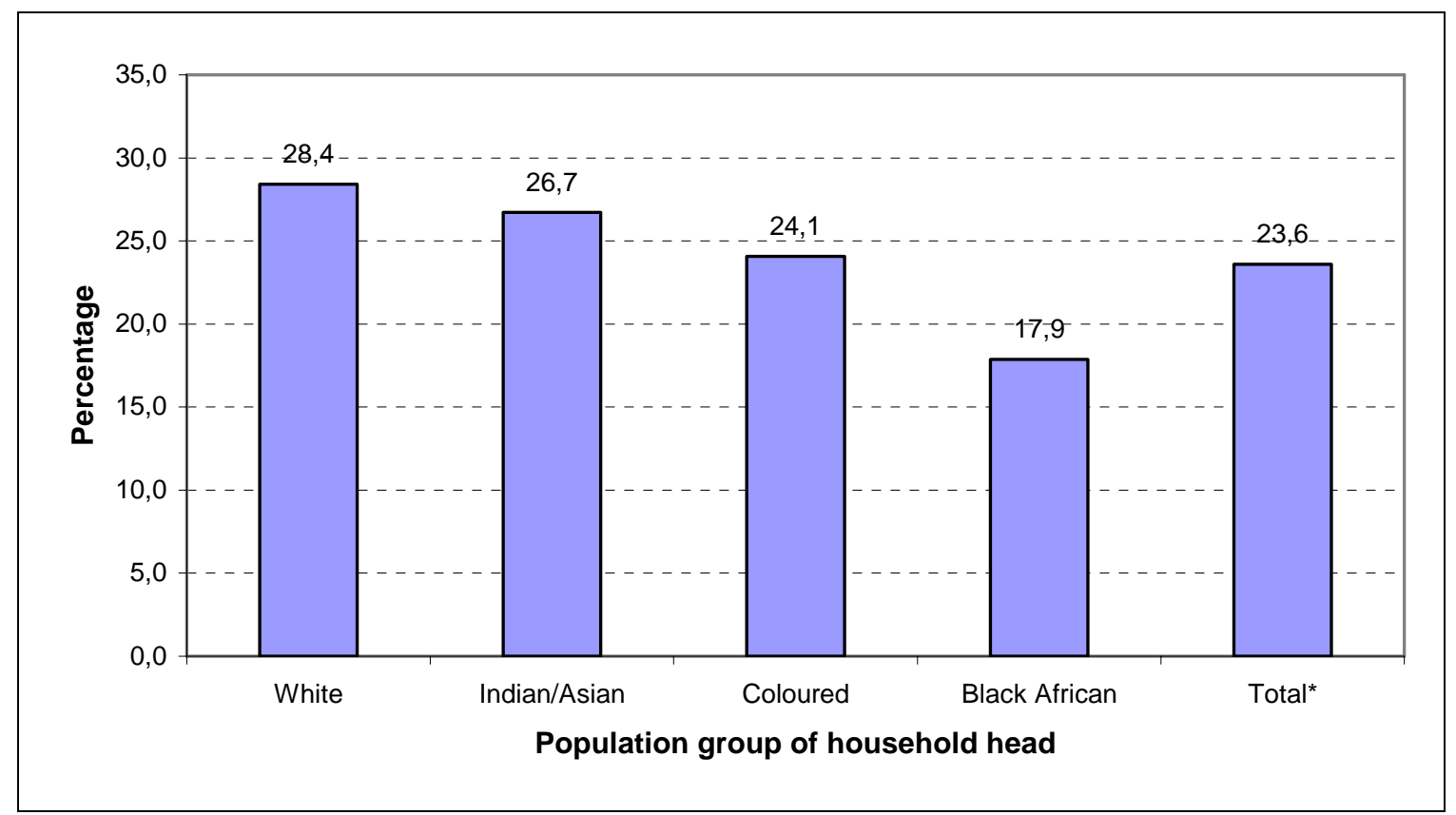

Total* includes households with unspecified population group of household head

Figure C2 - Proportion of total household expenditure on housing, water, electricity gas and other fuels by sex of household head

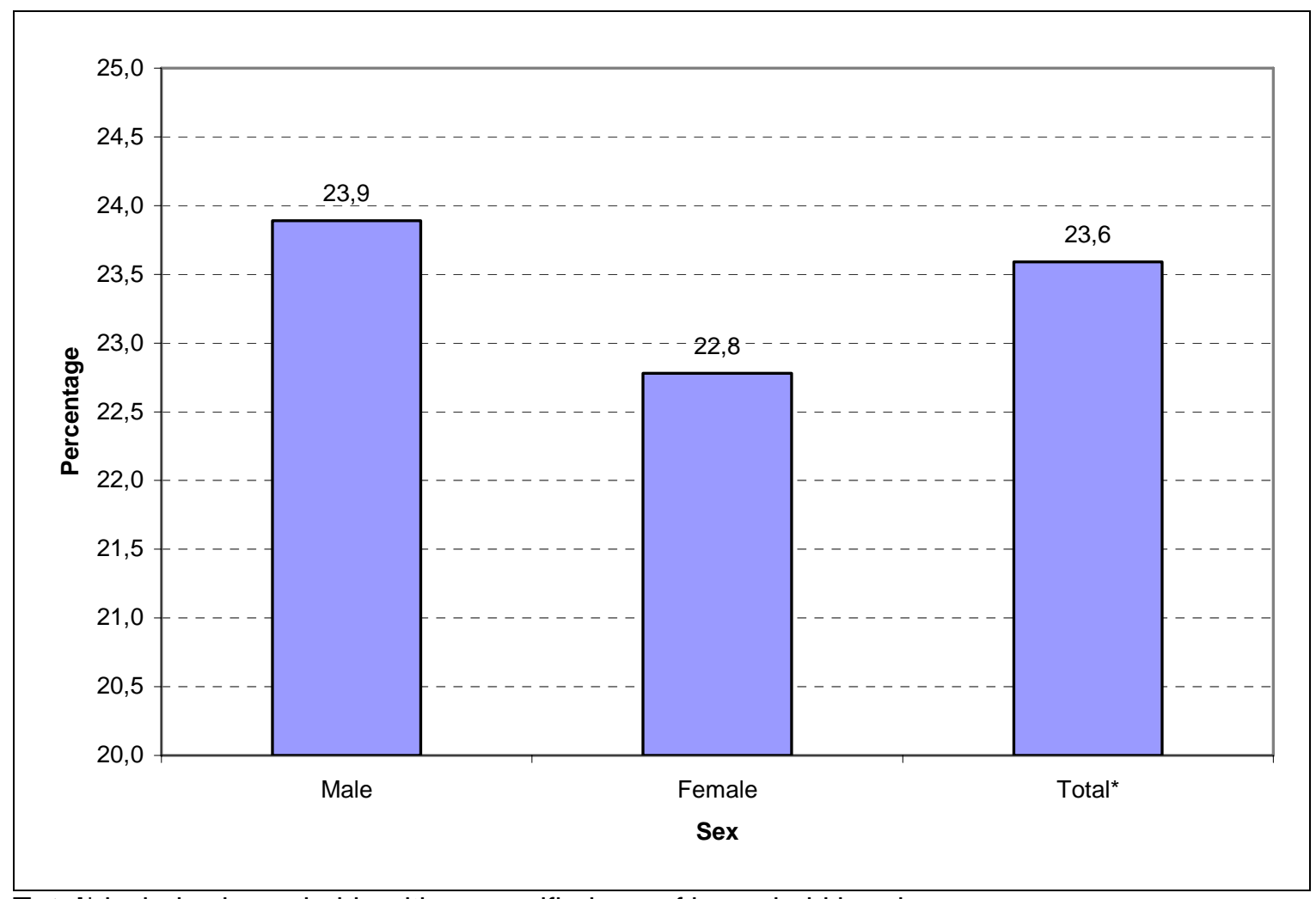

Total $^{\star}$ includes households with unspecified sex of household head 
Figure C3 - Proportion of total household expenditure on housing, water, electricity, gas, and other fuels by settlement type

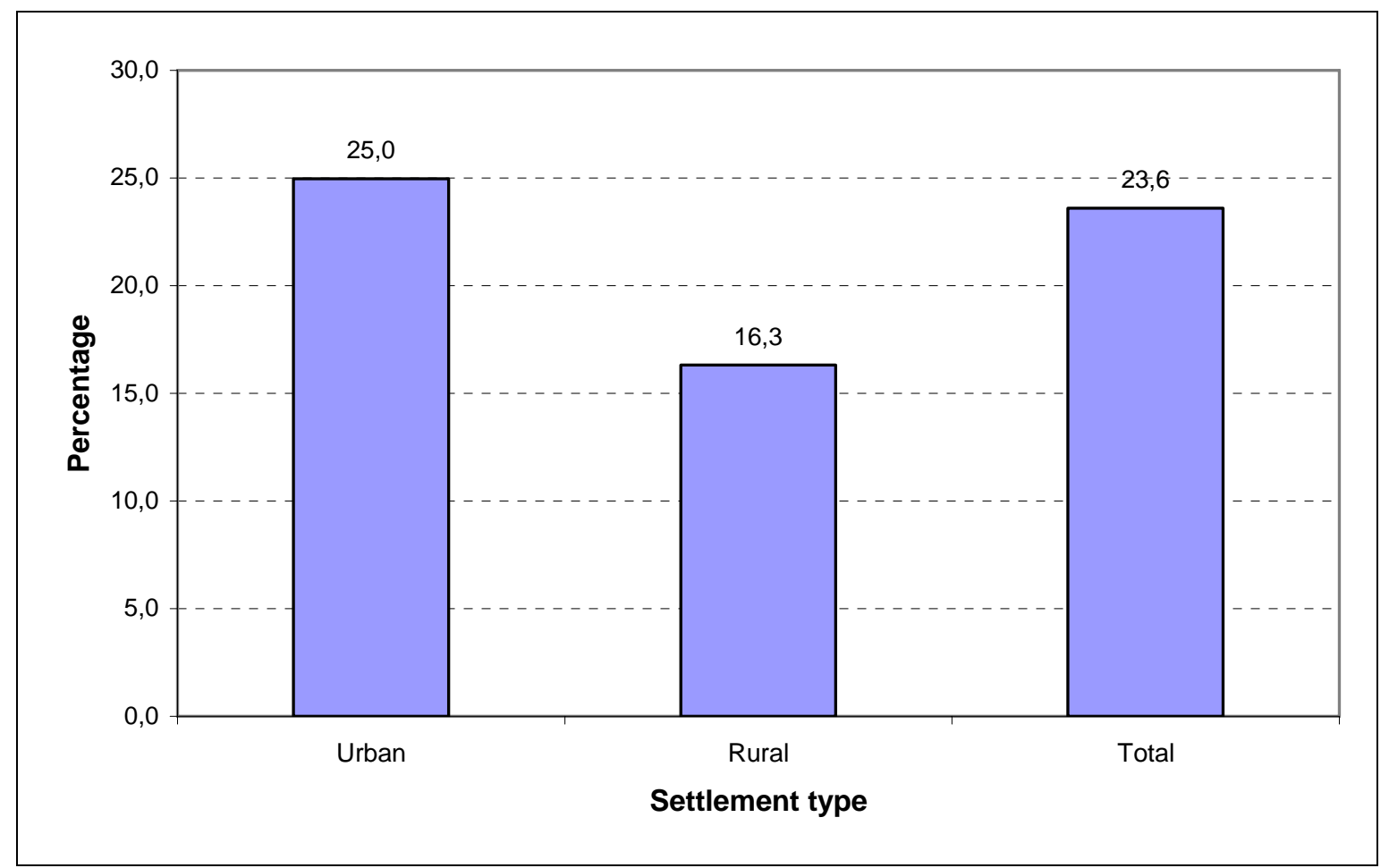

Figure C4 - Proportion of total household expenditure on housing, water, electricity, gas and other fuels by province

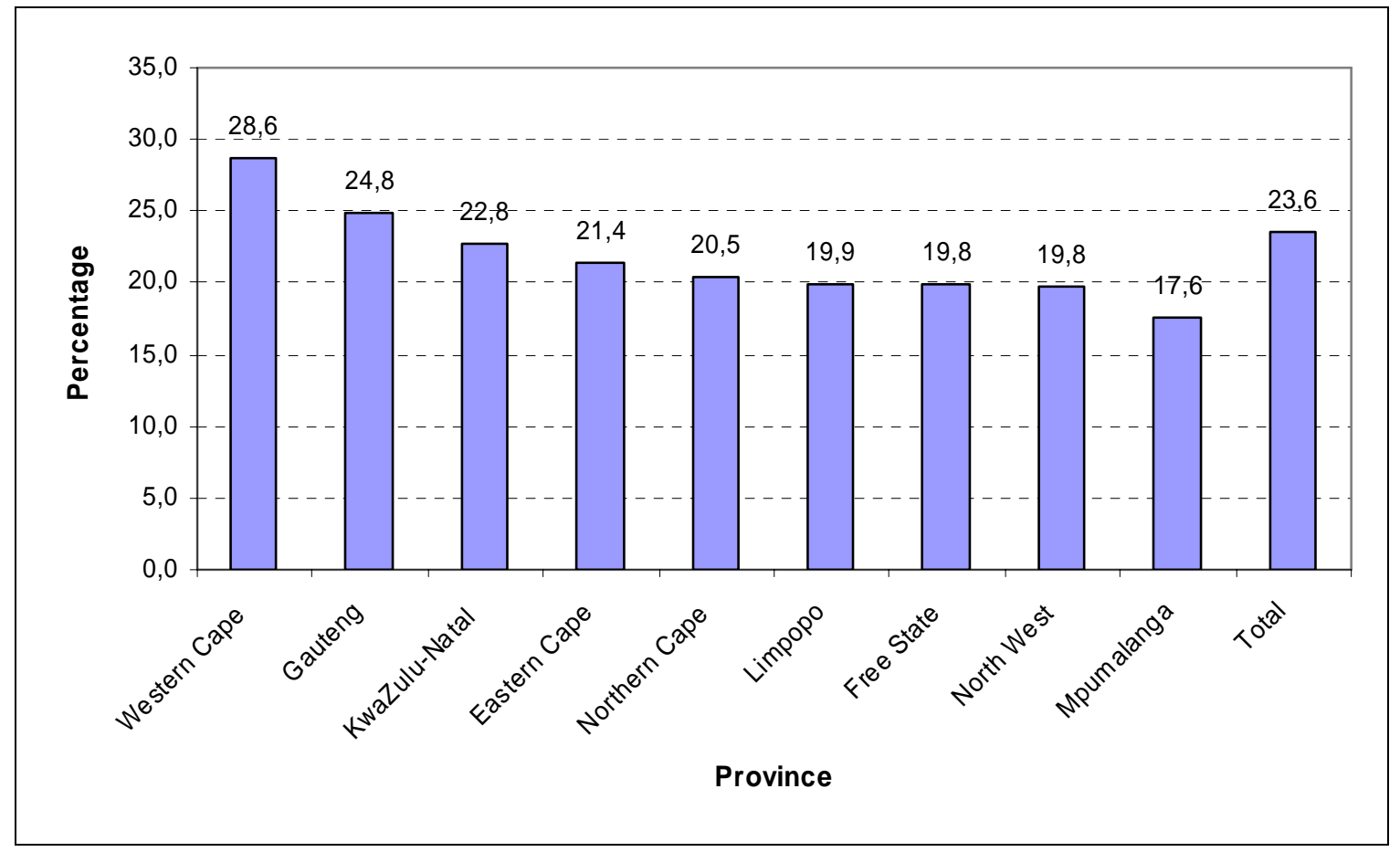


Figure D1 - Proportion of total household expenditure on furnishings, household equipment and routine maintenance of the dwelling by population group of household head

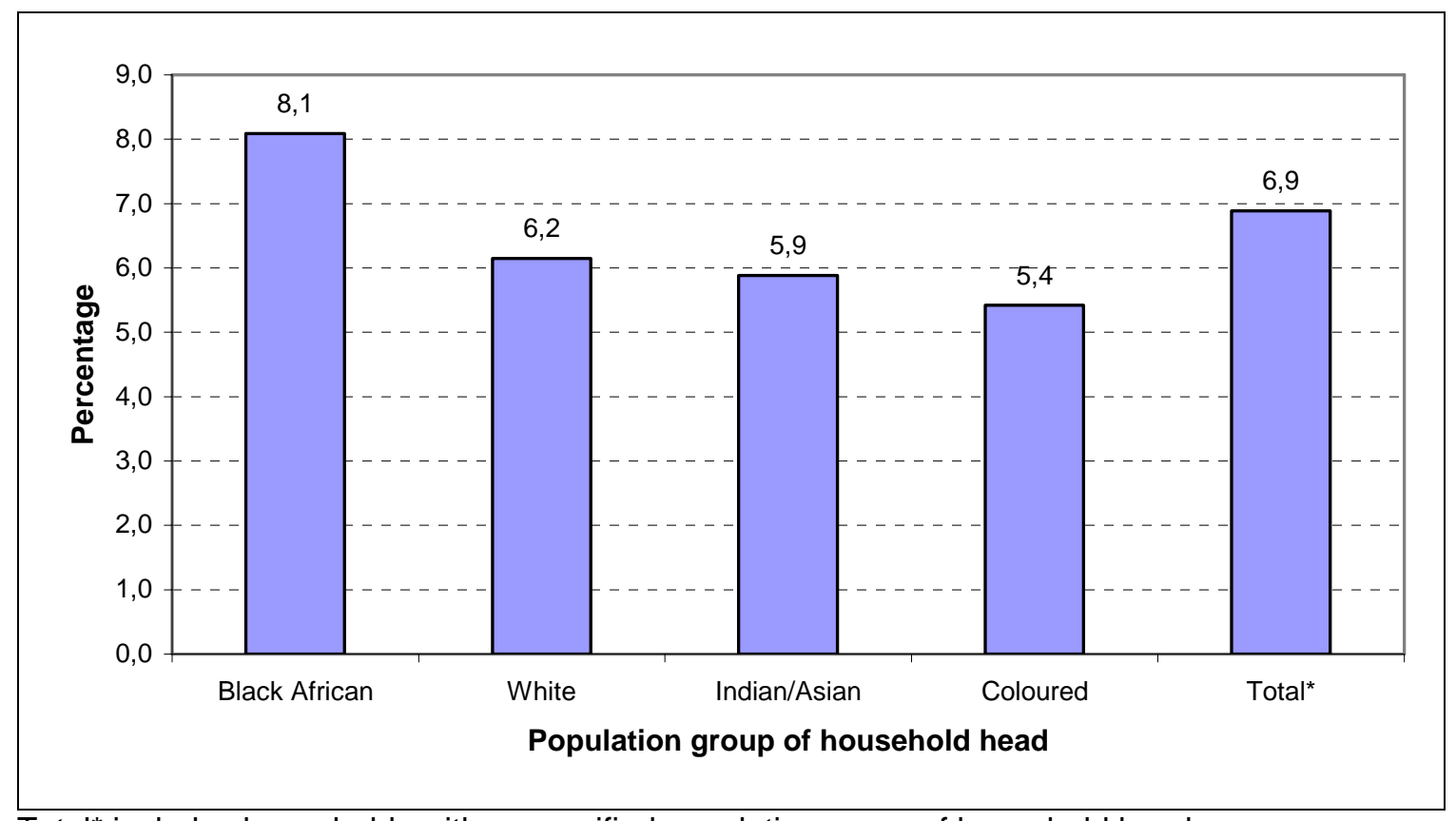

Total$^{\star}$ includes households with unspecified population group of household head

Figure D2 - Proportion of total household expenditure on furnishings, household equipment and routine maintenance of the dwelling by sex of household head

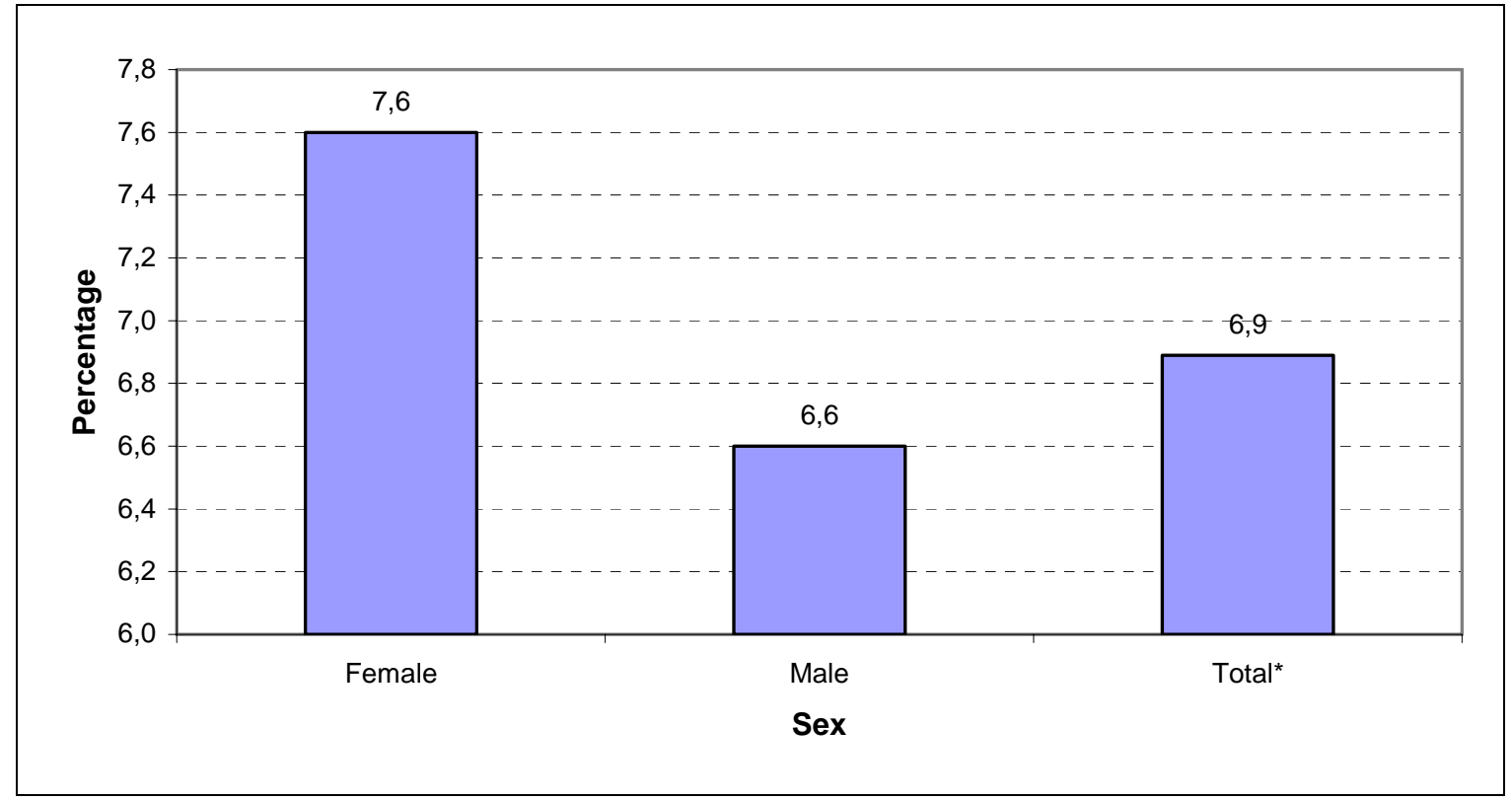

Total ${ }^{\star}$ includes households with unspecified sex of household head 
Figure D3 - Proportion of total household expenditure on furnishings, household equipment and routine maintenance of the dwelling by settlement type

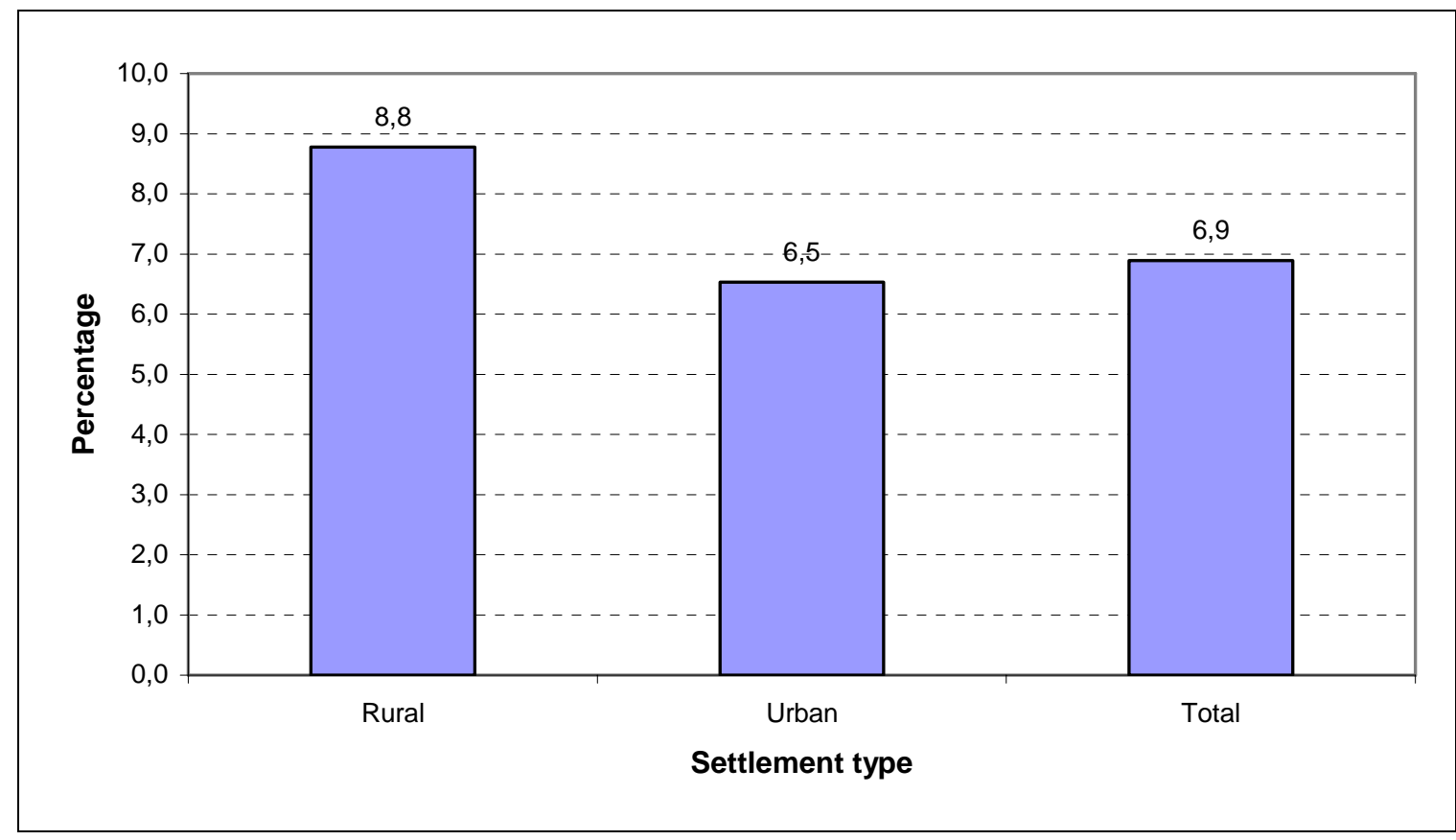

Figure D4 - Proportion of total household expenditure on furnishings, household equipment and routine maintenance of the dwelling by province

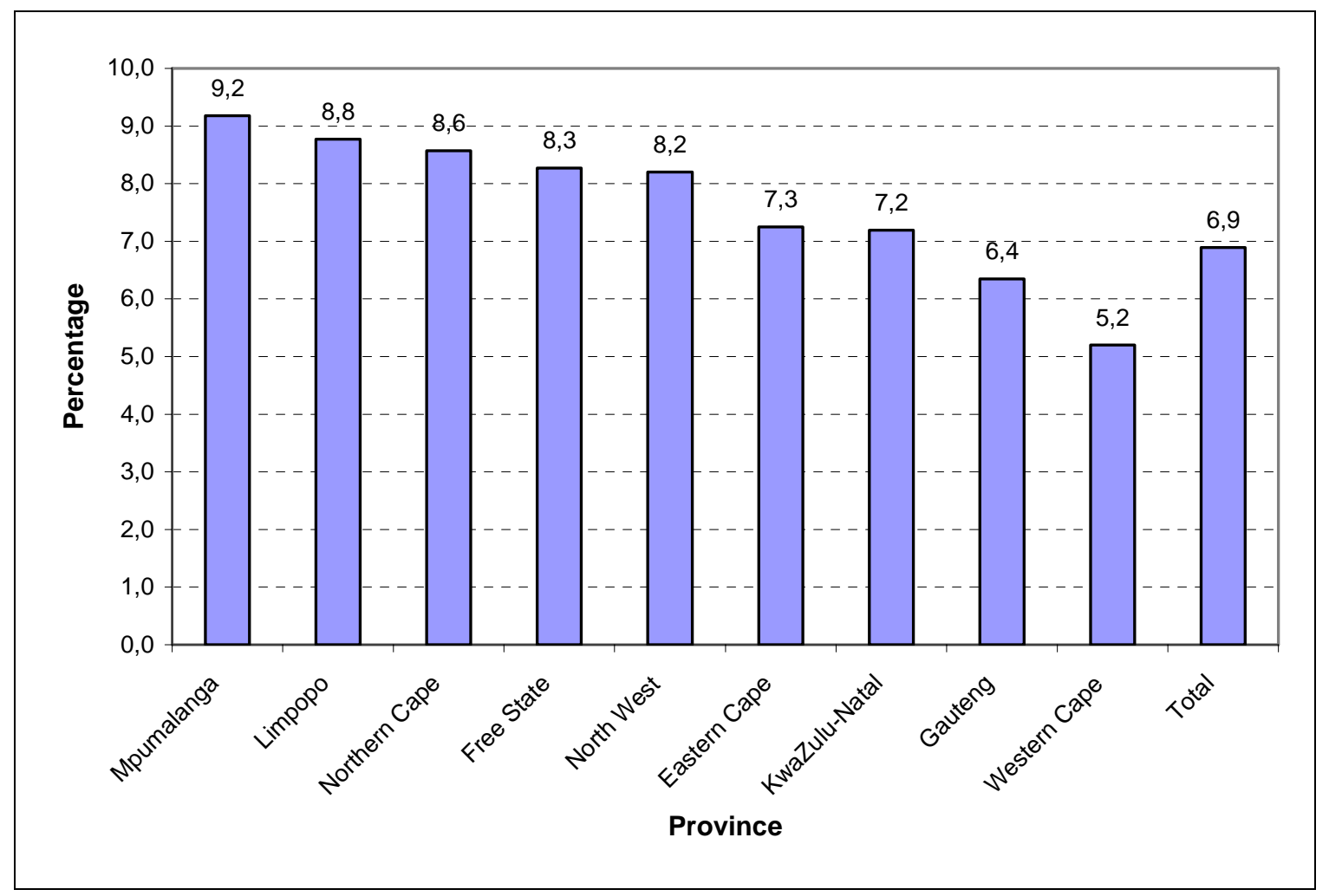


Figure E1 - Proportion of total household expenditure on health by population group of household head

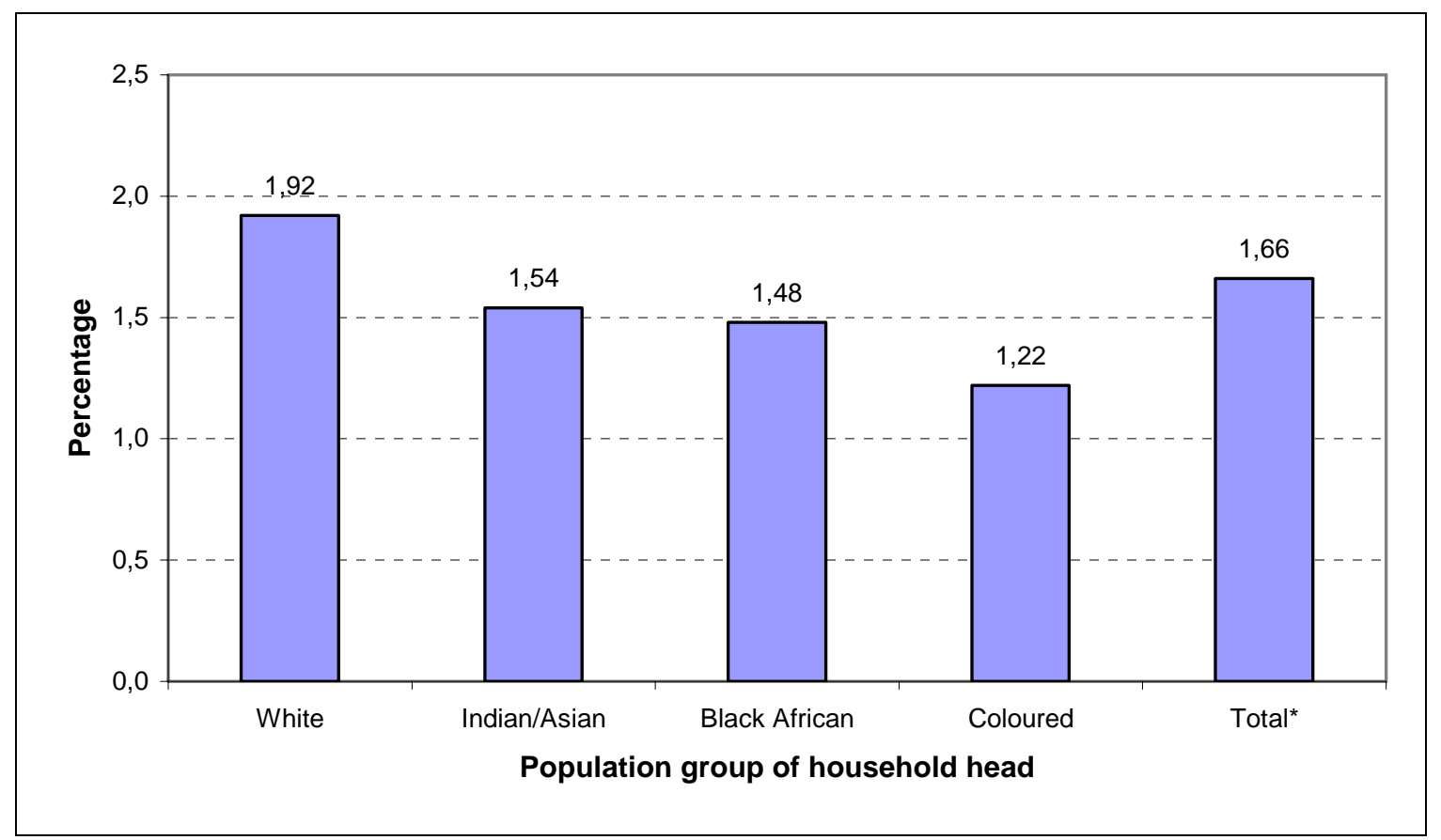

Total* includes households with unspecified population group of household head

Figure E2 - Proportion of total household expenditure on health by sex of household head

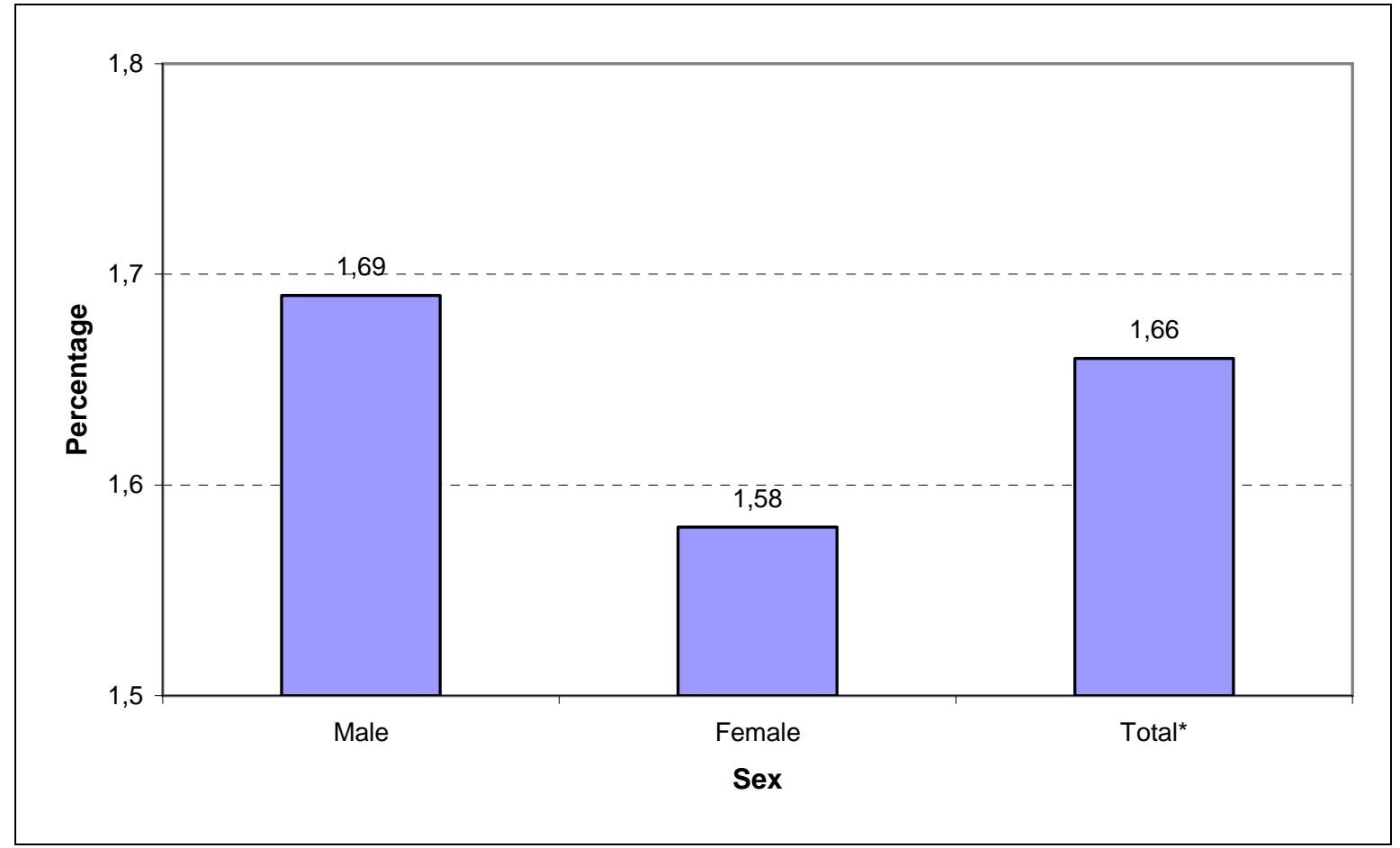

Total $^{*}$ includes households with unspecified sex of household head 
Figure E3 - Proportion of total household expenditure on health by settlement type

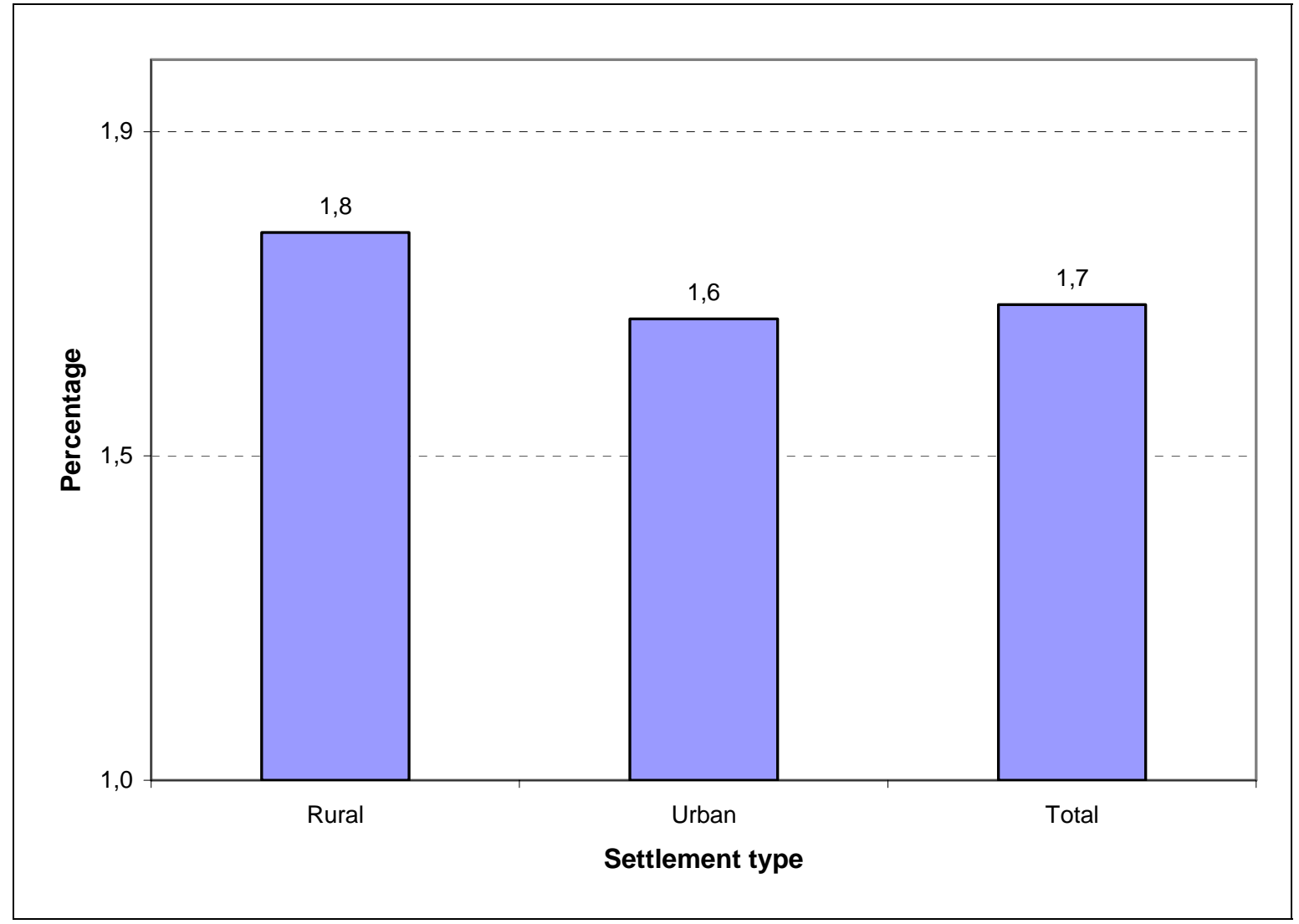

Figure E4 - Proportion of total household expenditure on health by province

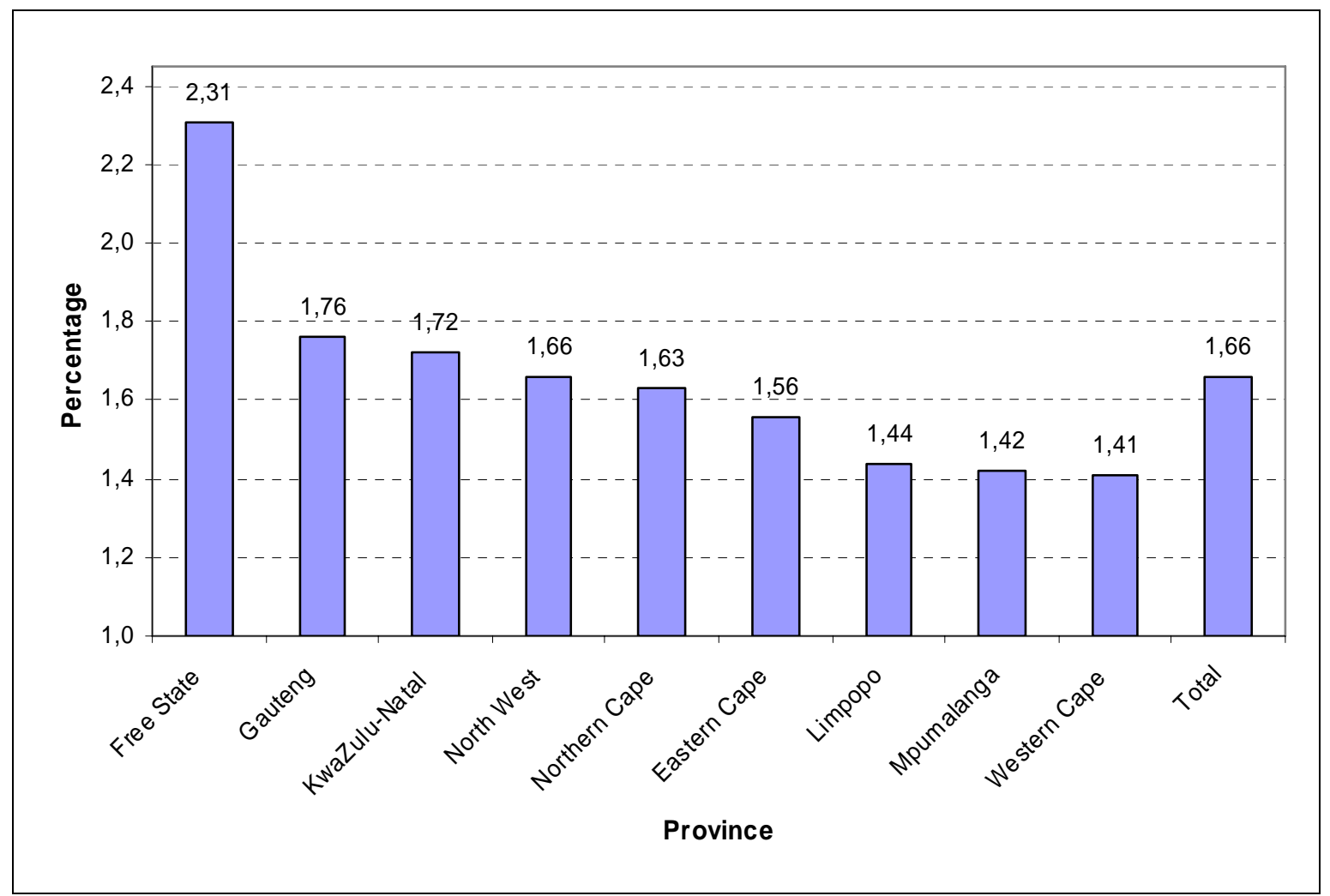


Figure F1 - Proportion of total household expenditure on transport by population group of household head

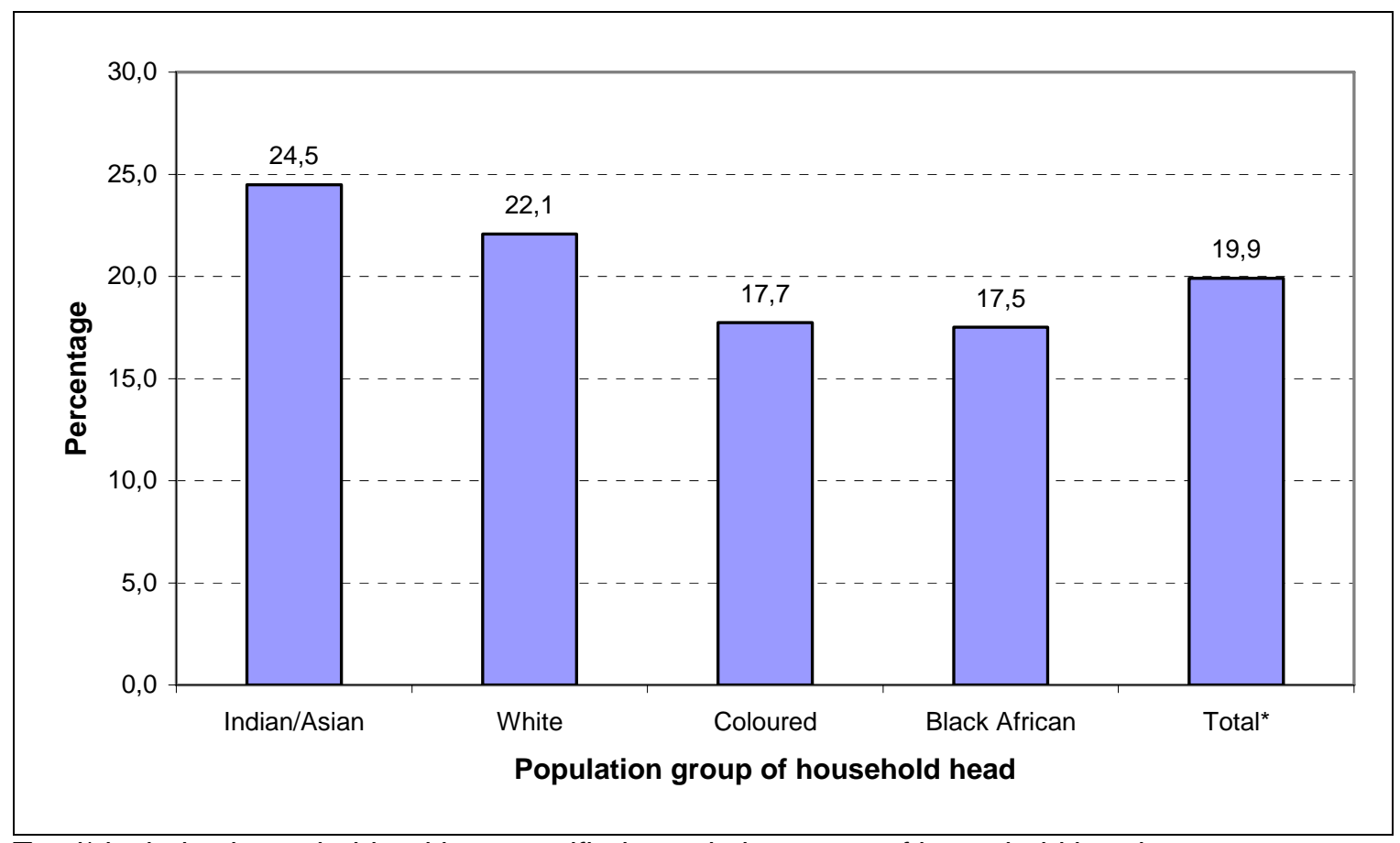

Total$^{*}$ includes households with unspecified population group of household head

Figure F2 - Proportion of total household expenditure on transport by sex of household head

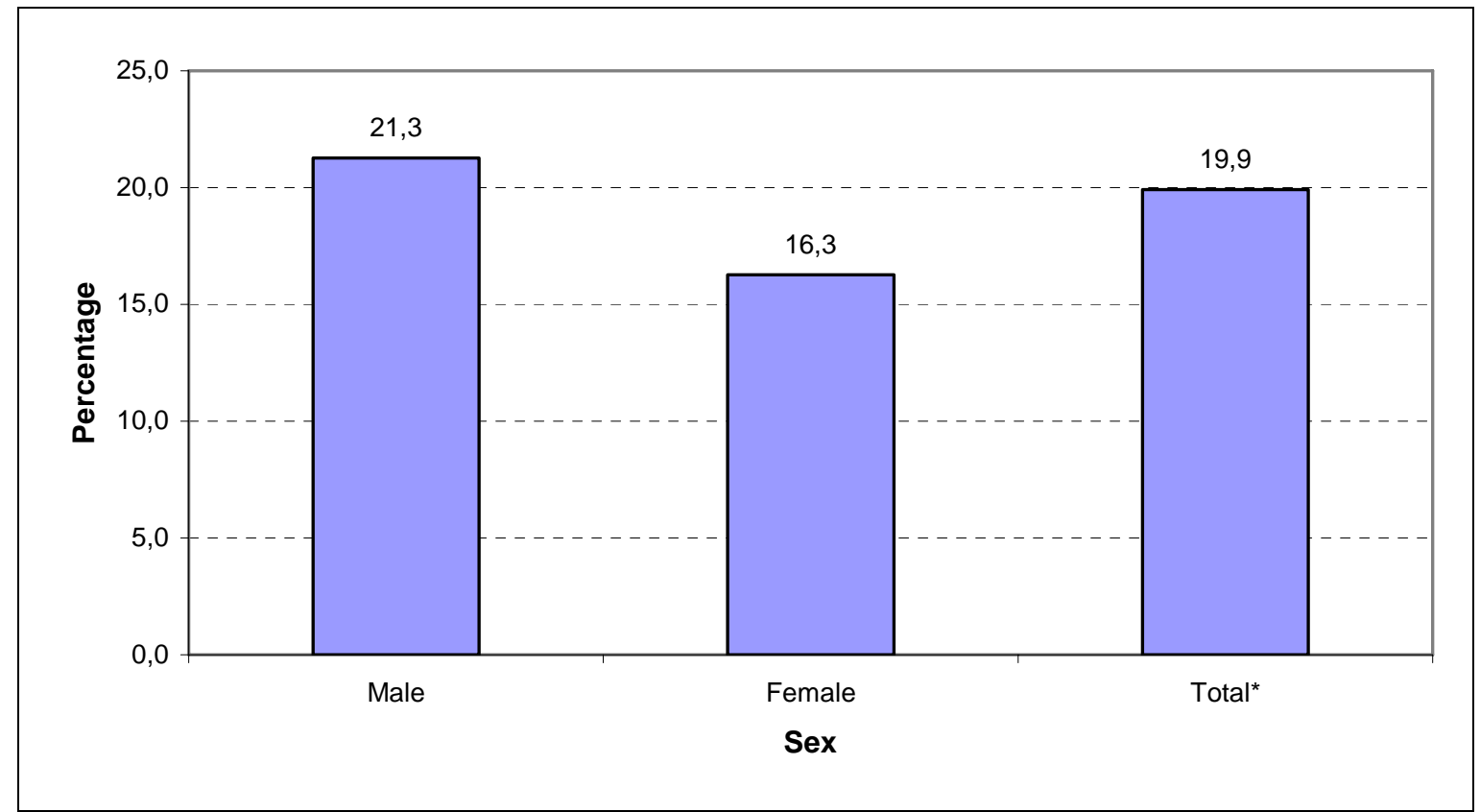

Total* includes households with unspecified sex of household head 
Figure F3 - Proportion of total household expenditure on transport by settlement type

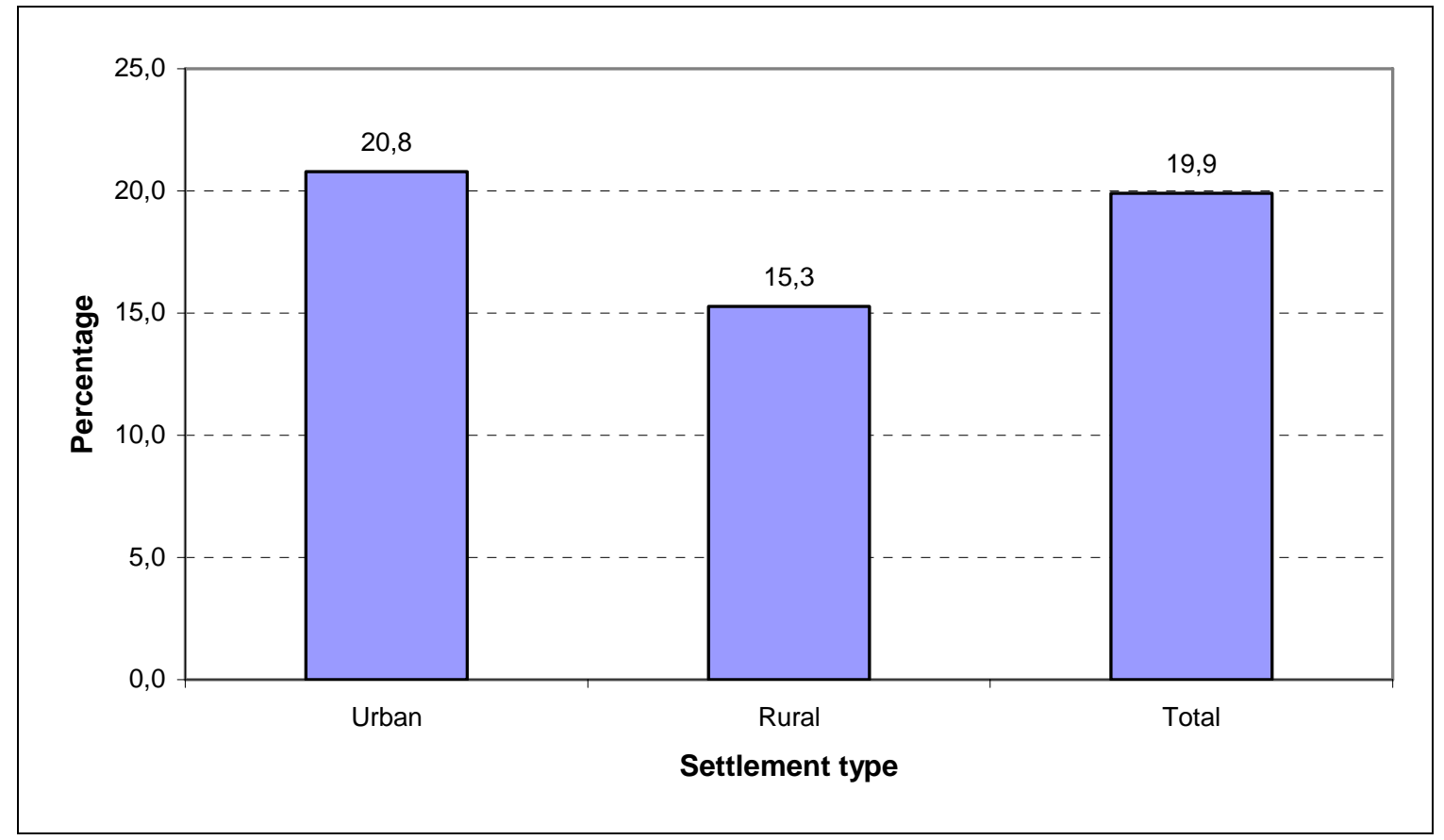

Figure F4 - Proportion of total household expenditure on transport by province

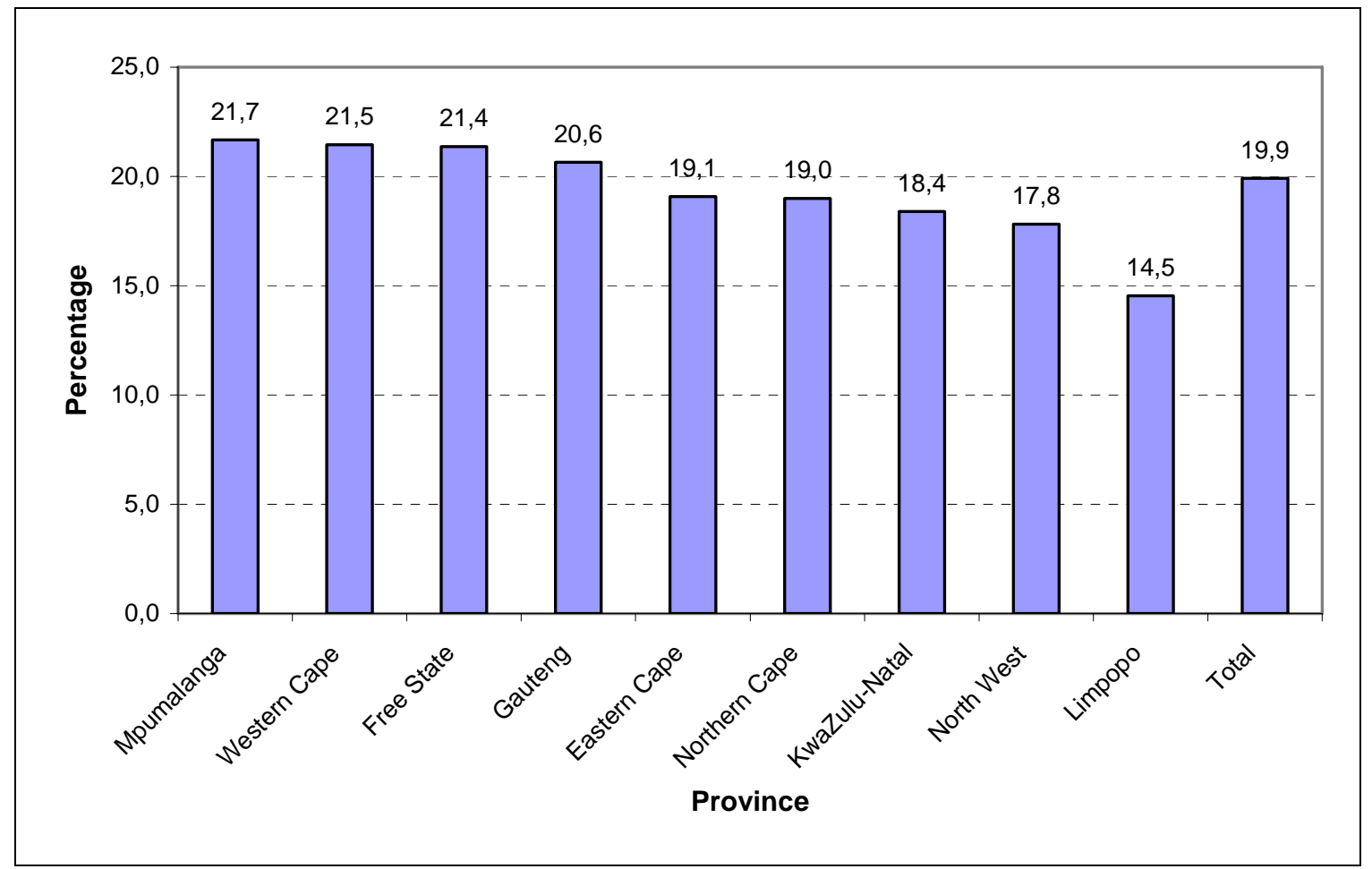


Figure G1 - Proportion of total household expenditure on communication by population group of household head

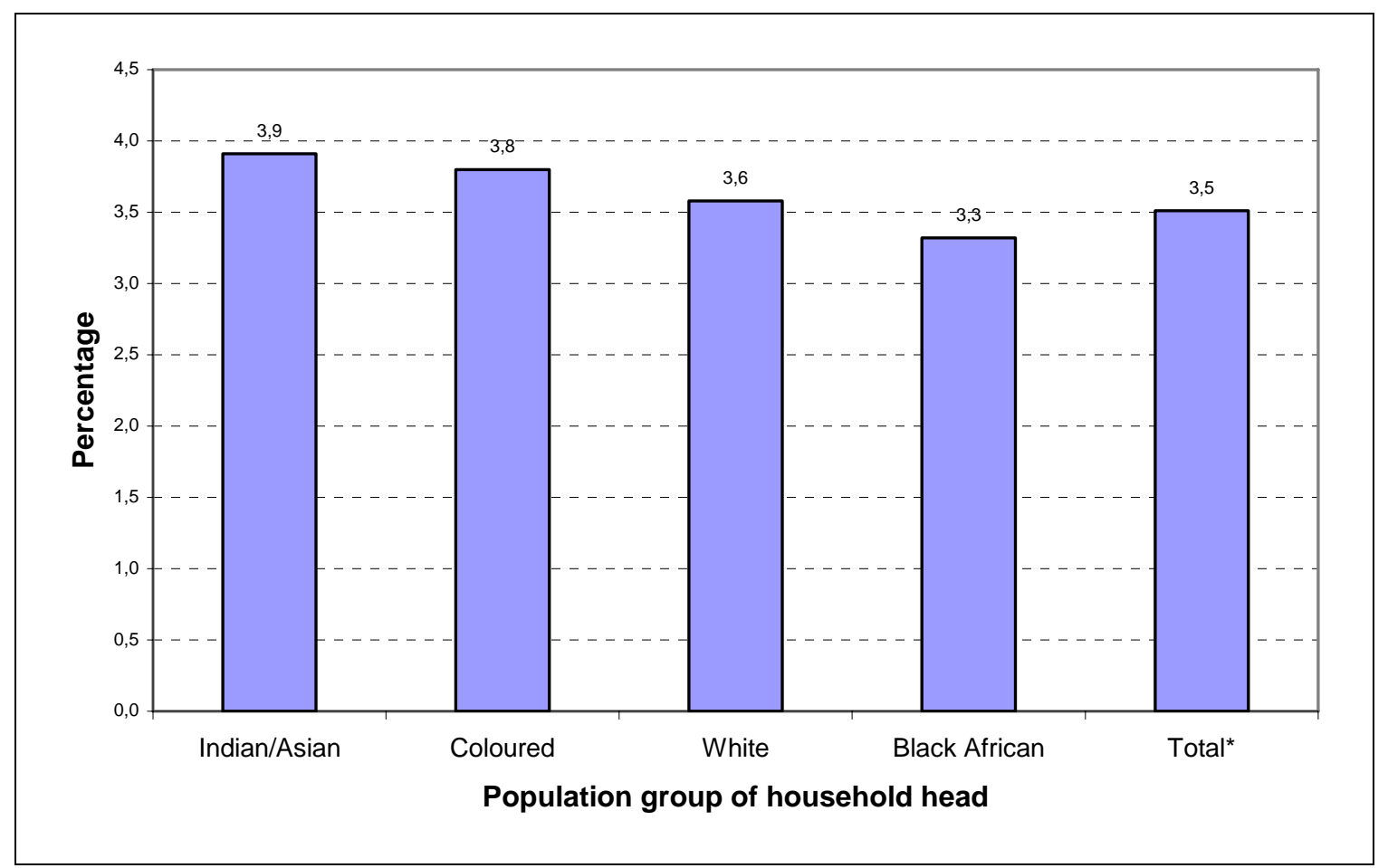

Total* includes households with unspecified population group of household head

Figure G2 - Proportion of total household expenditure on communication by sex of household head

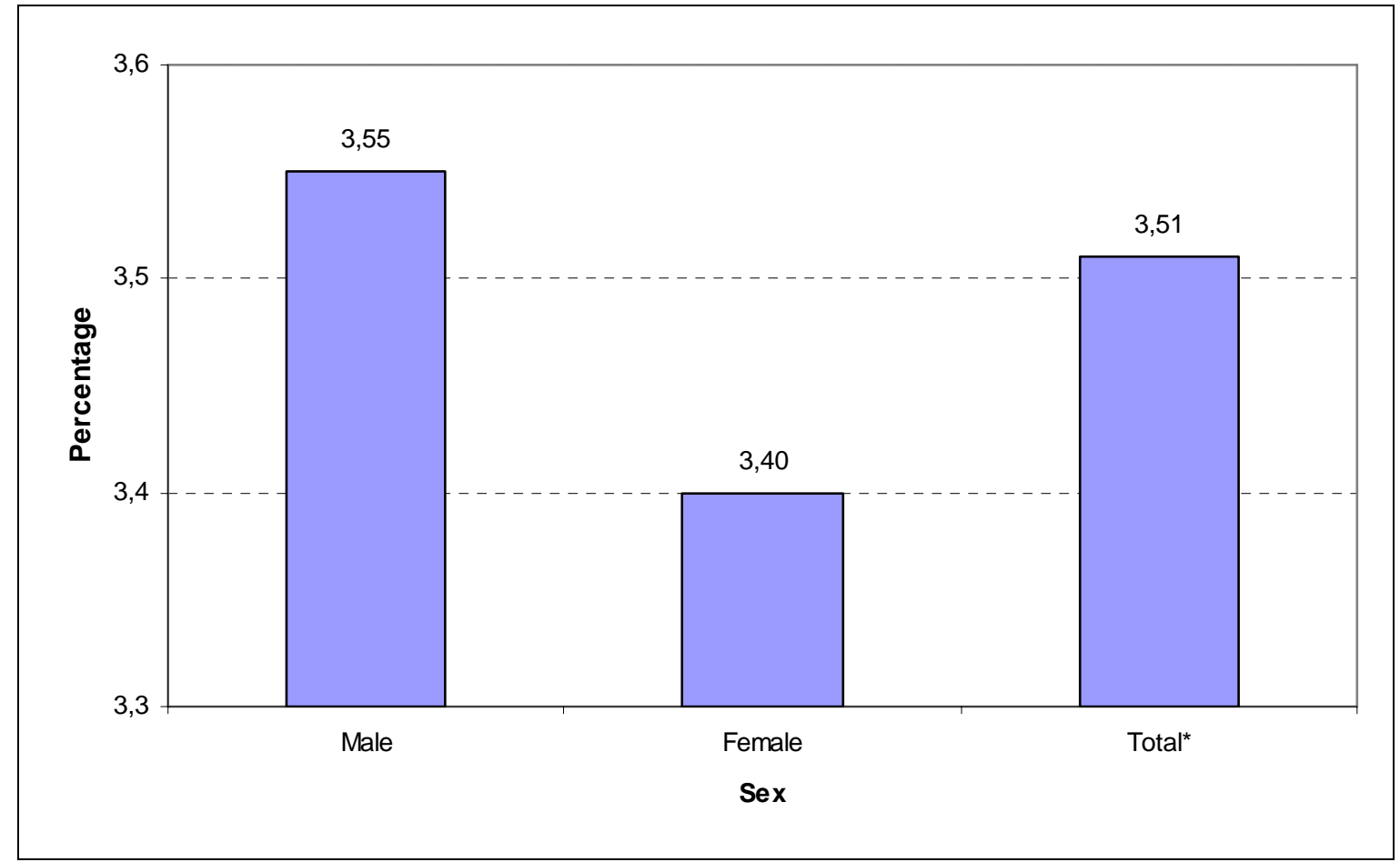

Total $^{\star}$ includes households with unspecified sex of household head 
Figure G3 - Proportion of total household expenditure on communication by settlement type

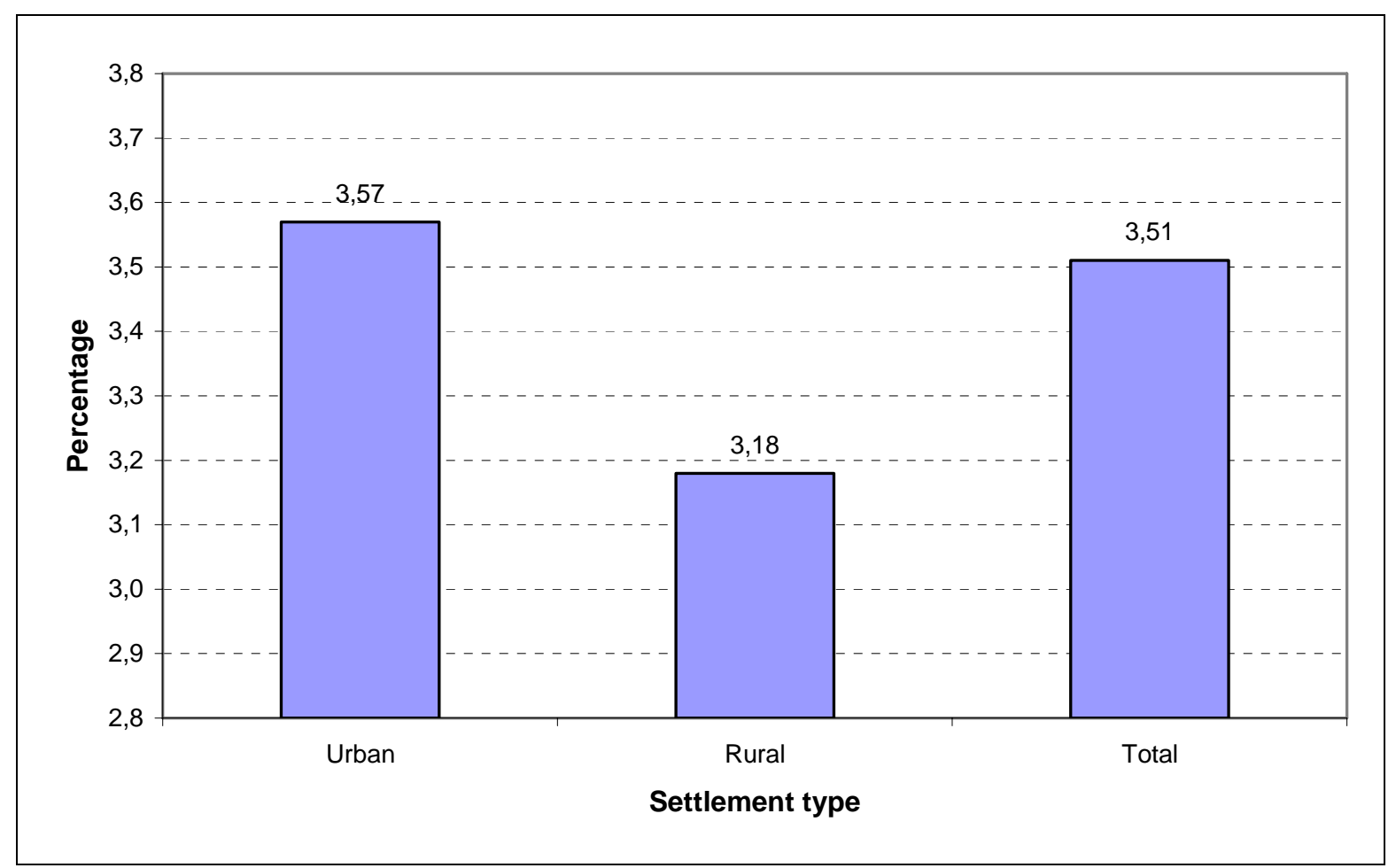

Figure G4 - Proportion of total household expenditure on communication by province

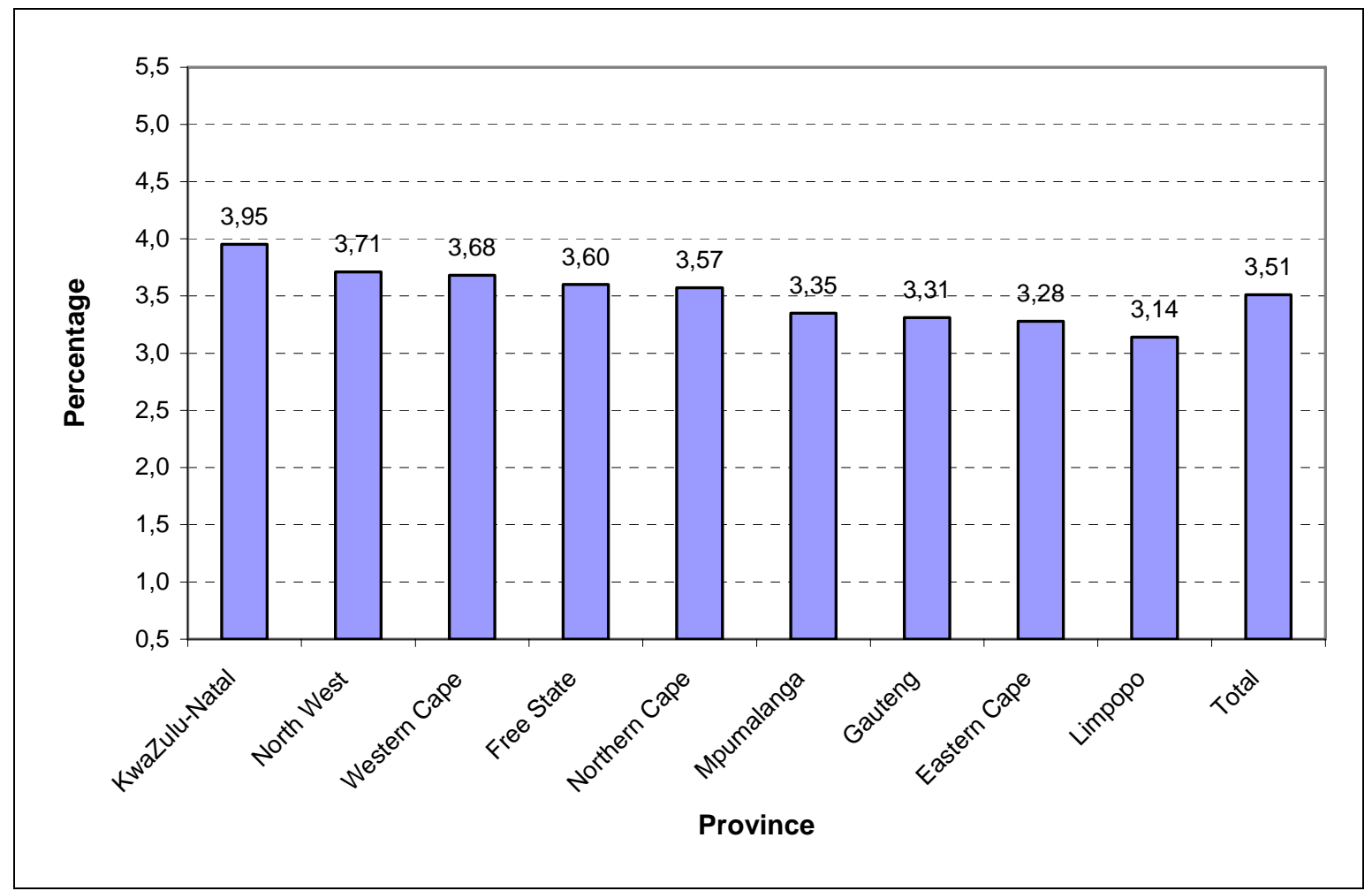


Figure H1 - Proportion of total household expenditure on recreation and culture by population group of household head

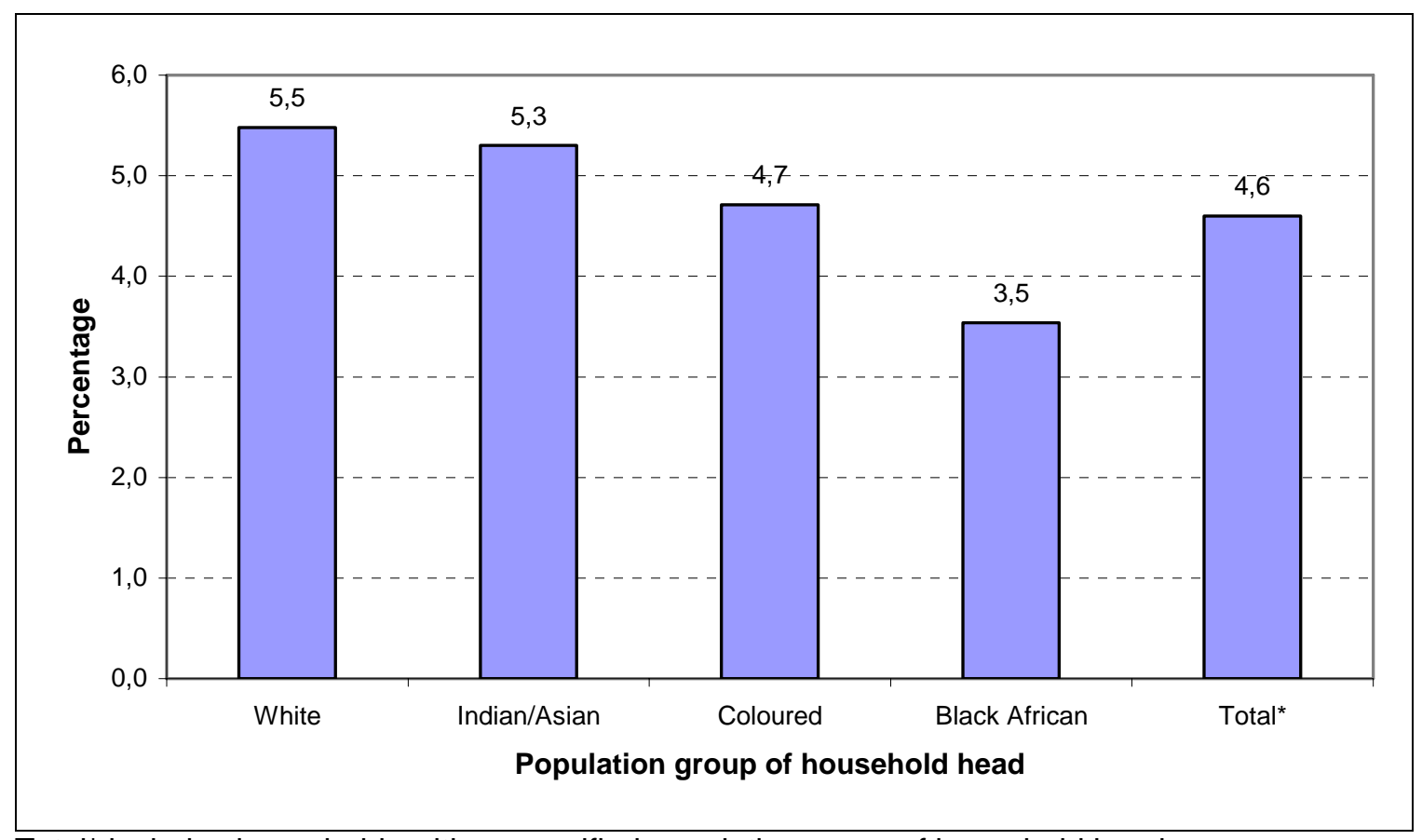

Total $^{*}$ includes households with unspecified population group of household head

Figure H2 - Proportion of total household expenditure on recreation and culture by sex of household head

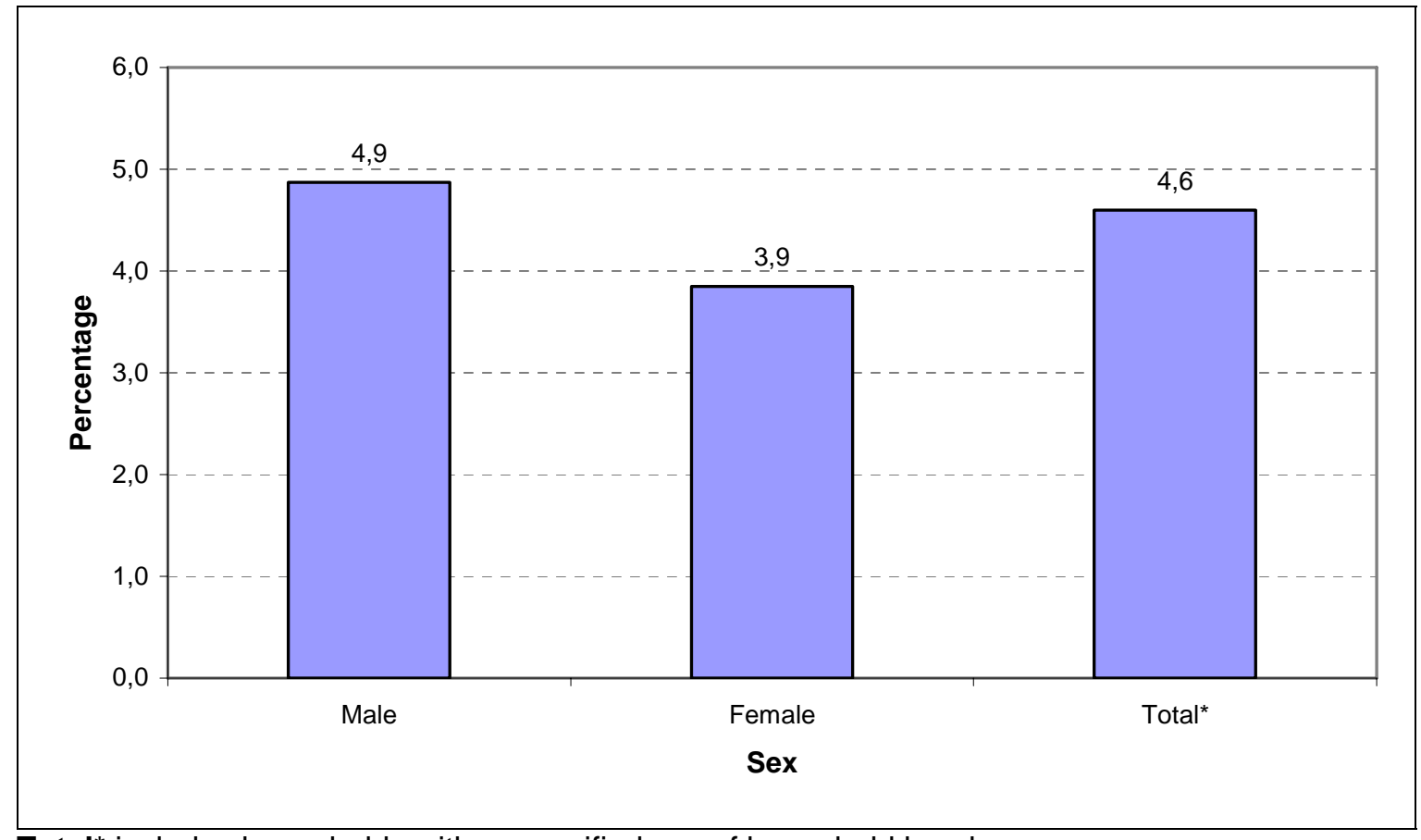

Total $^{*}$ includes households with unspecified sex of household head 
Figure H3 - Proportion of total household expenditure on recreation and culture by settlement type

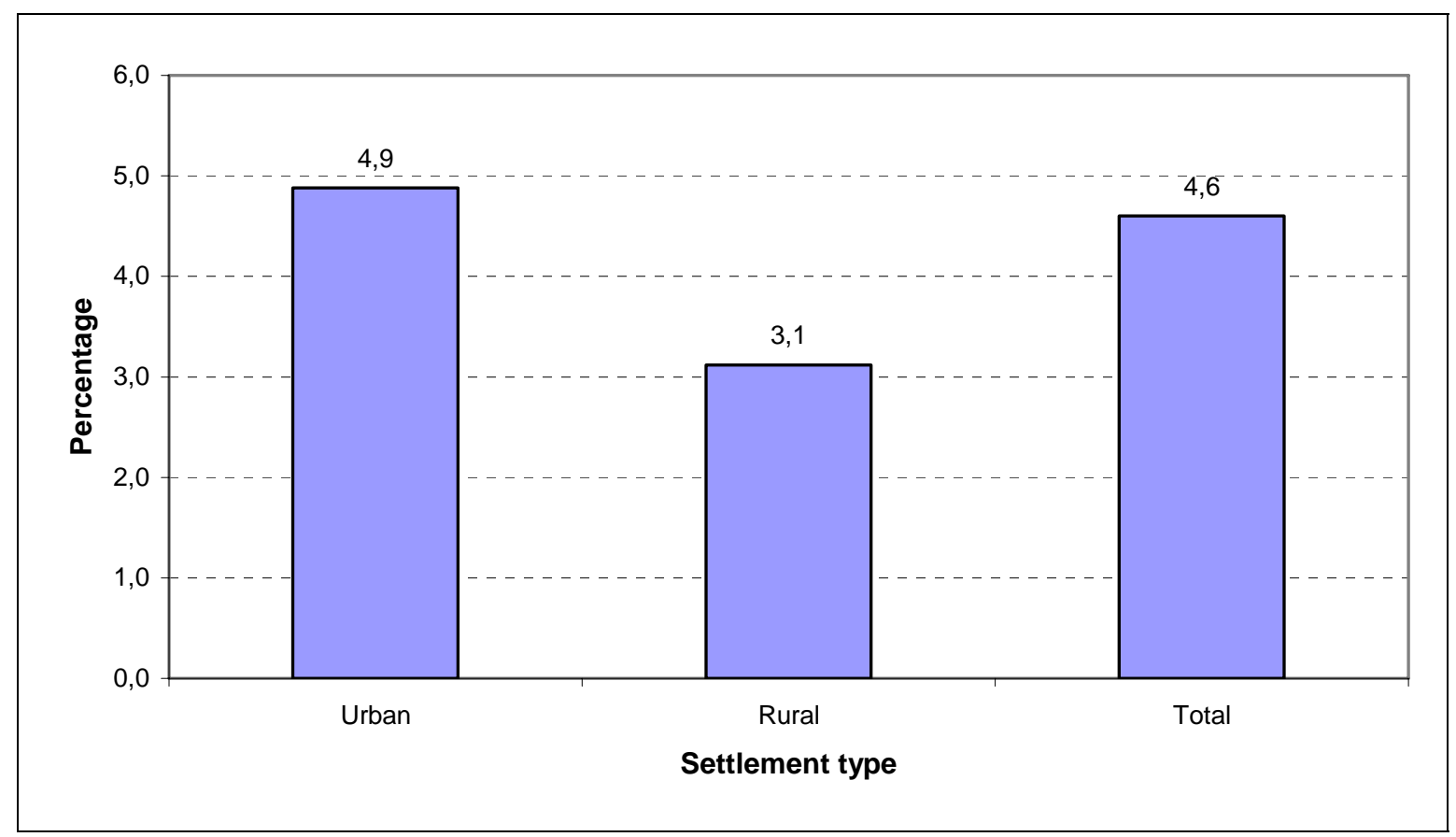

Figure H4 - Proportion of total household expenditure on recreation and culture by province

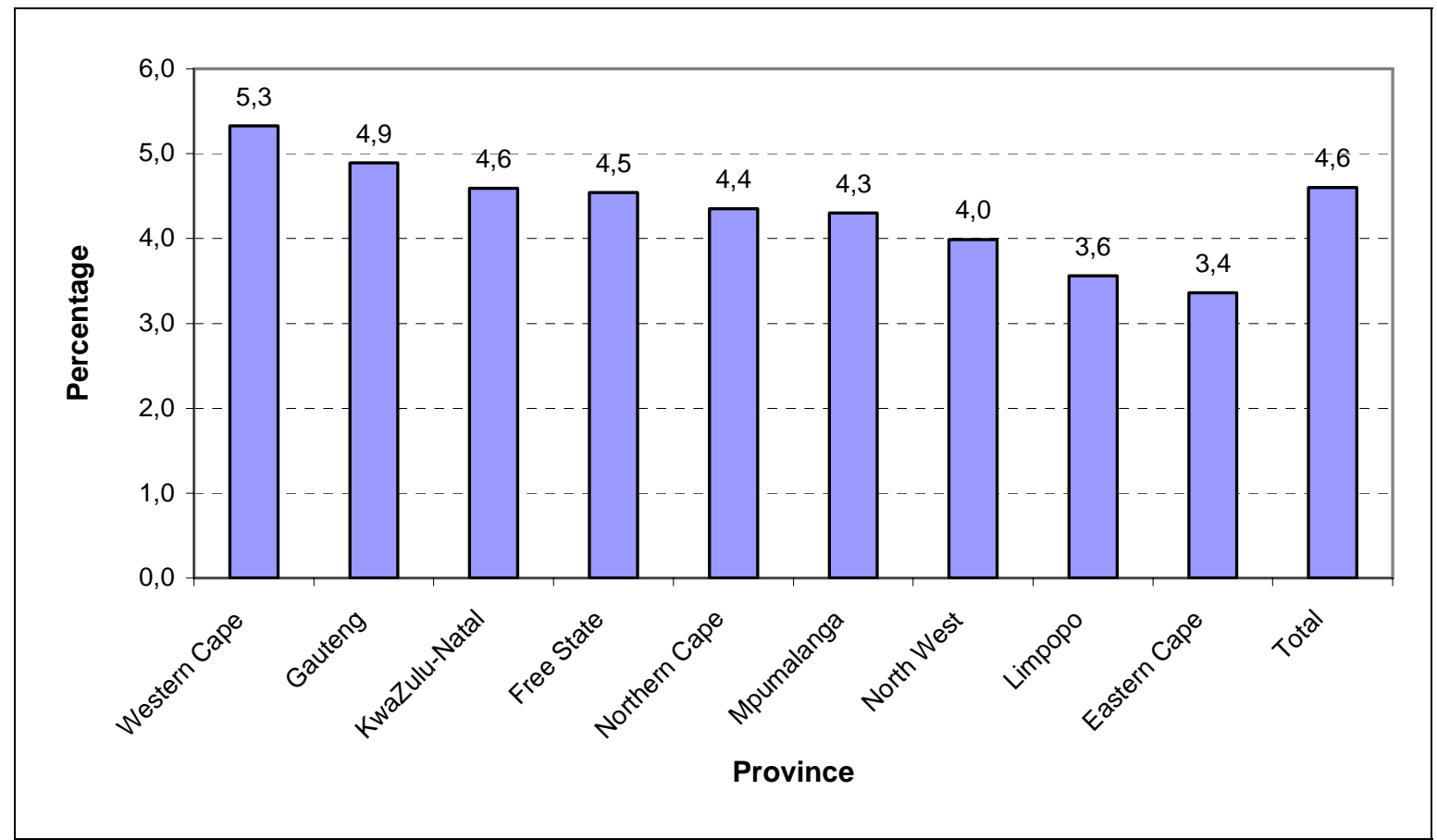


Figure I1 - Proportion of total household expenditure on education by population group of household head

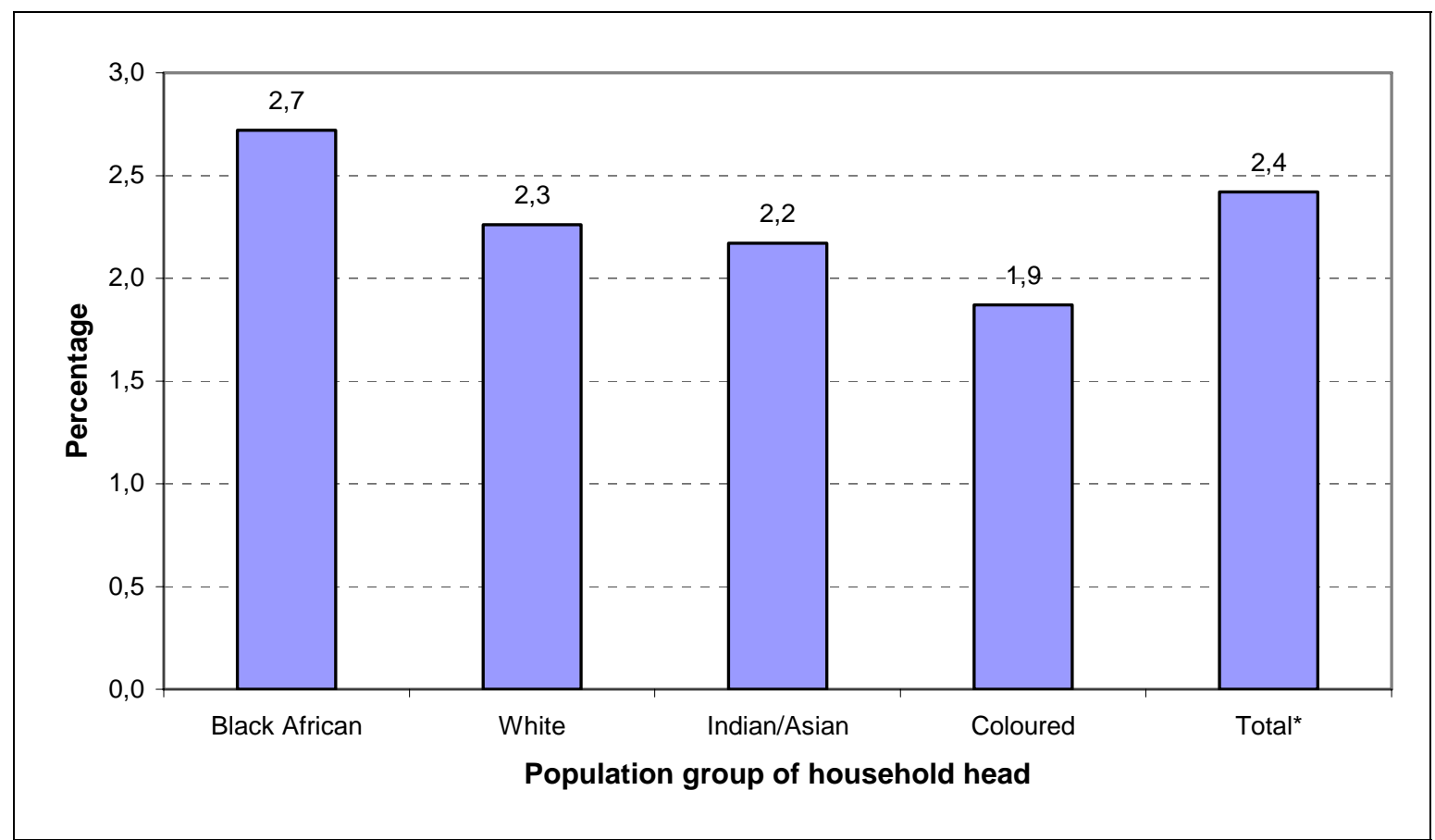

Total* includes households with unspecified population group of household head

Figure 12 - Proportion of total household expenditure on education by sex of household head

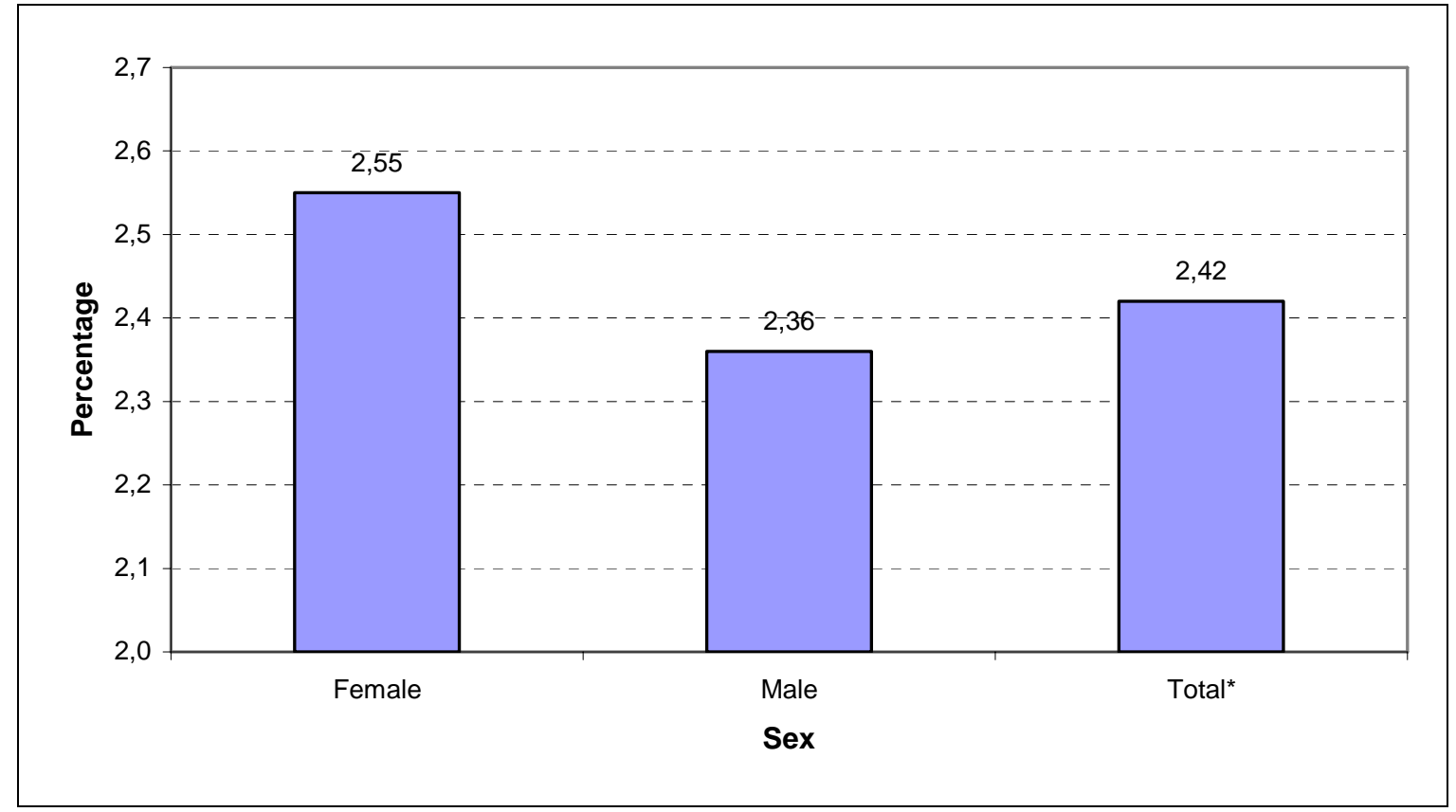

Total $^{*}$ includes households with unspecified sex of household head 
Figure I3 - Proportion of total household expenditure on education by settlement type

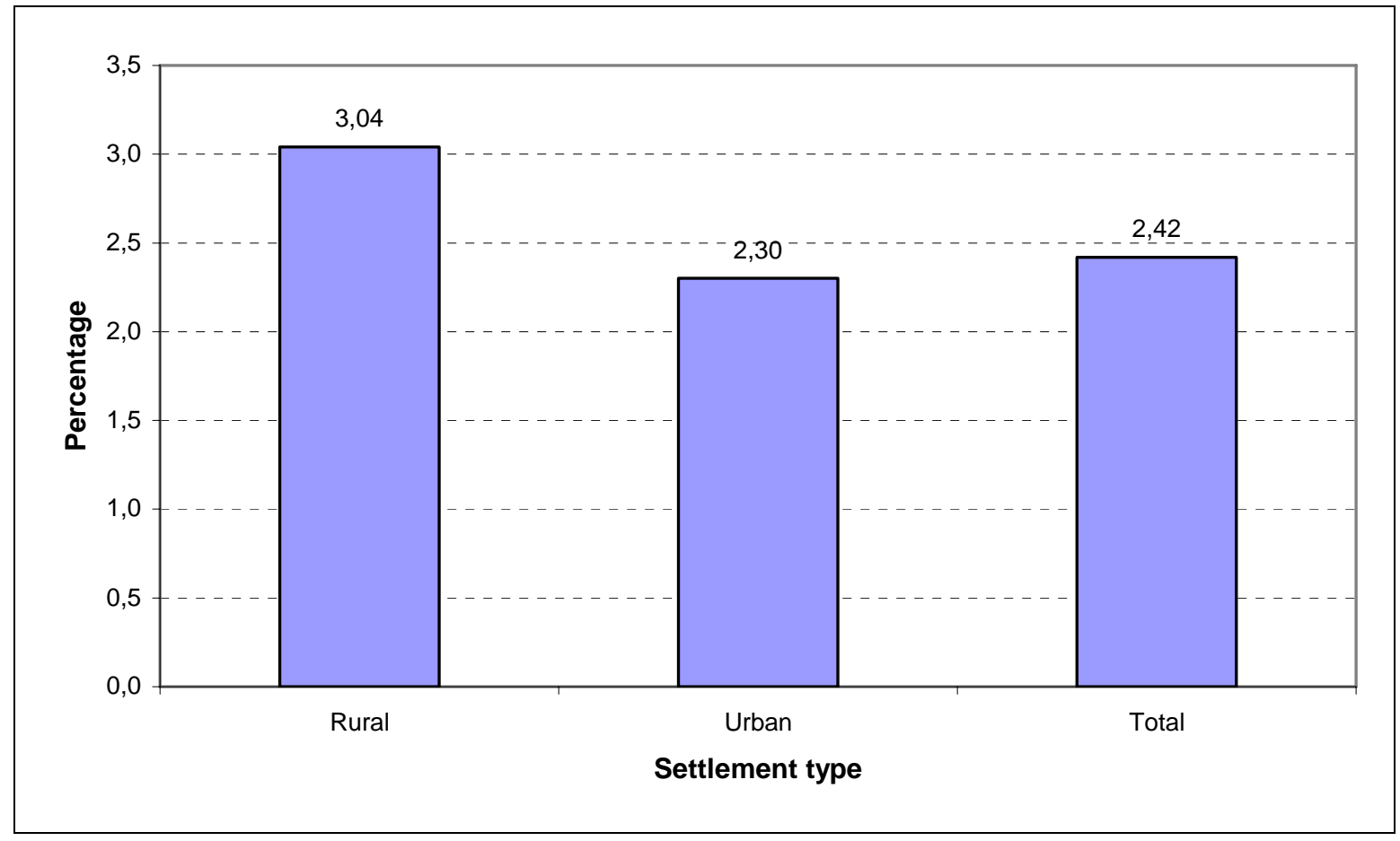

Figure 14 - Proportion of total household expenditure on education by province

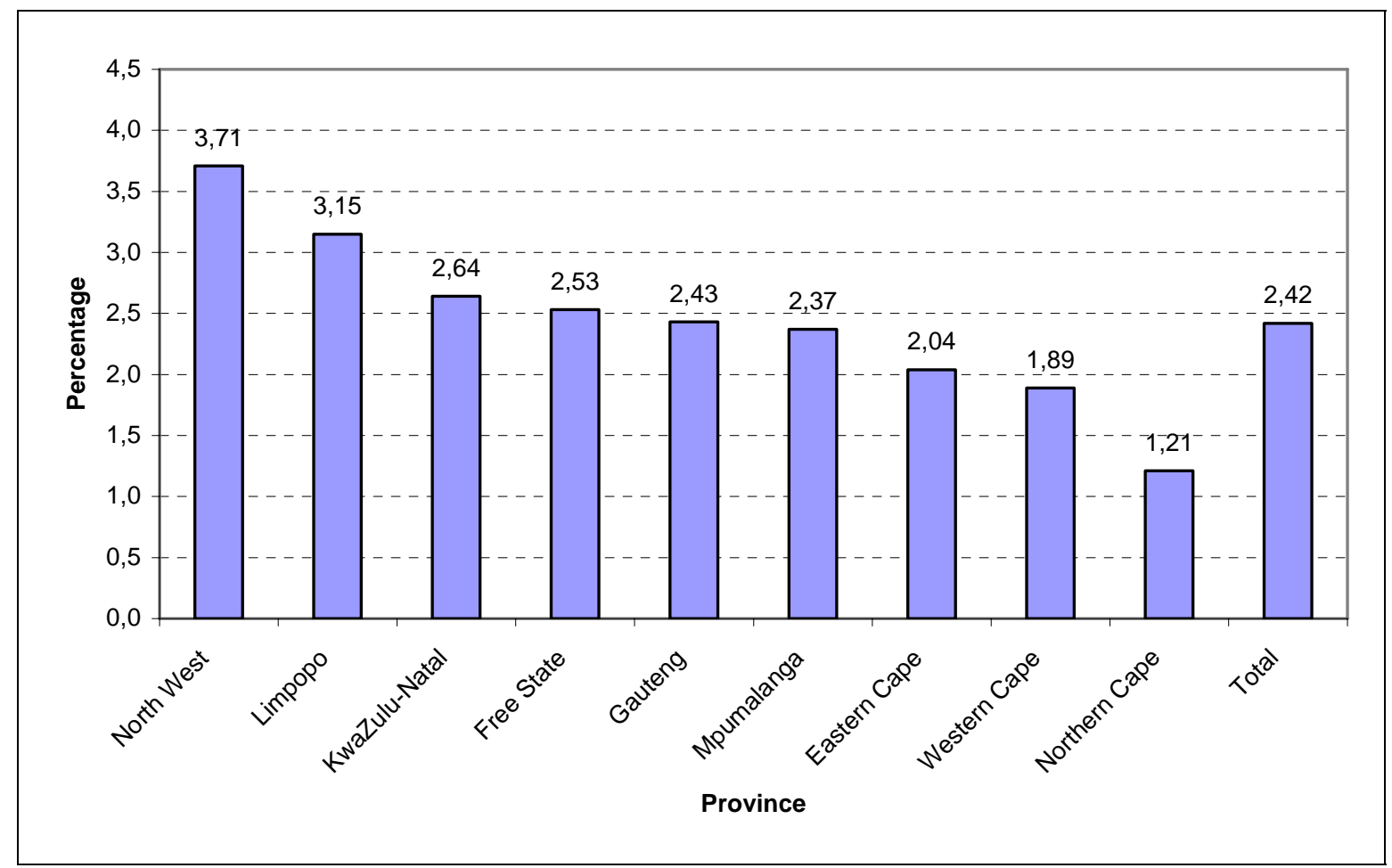


Figure J1 - Proportion of total household expenditure on restaurants and hotels by population group of household head

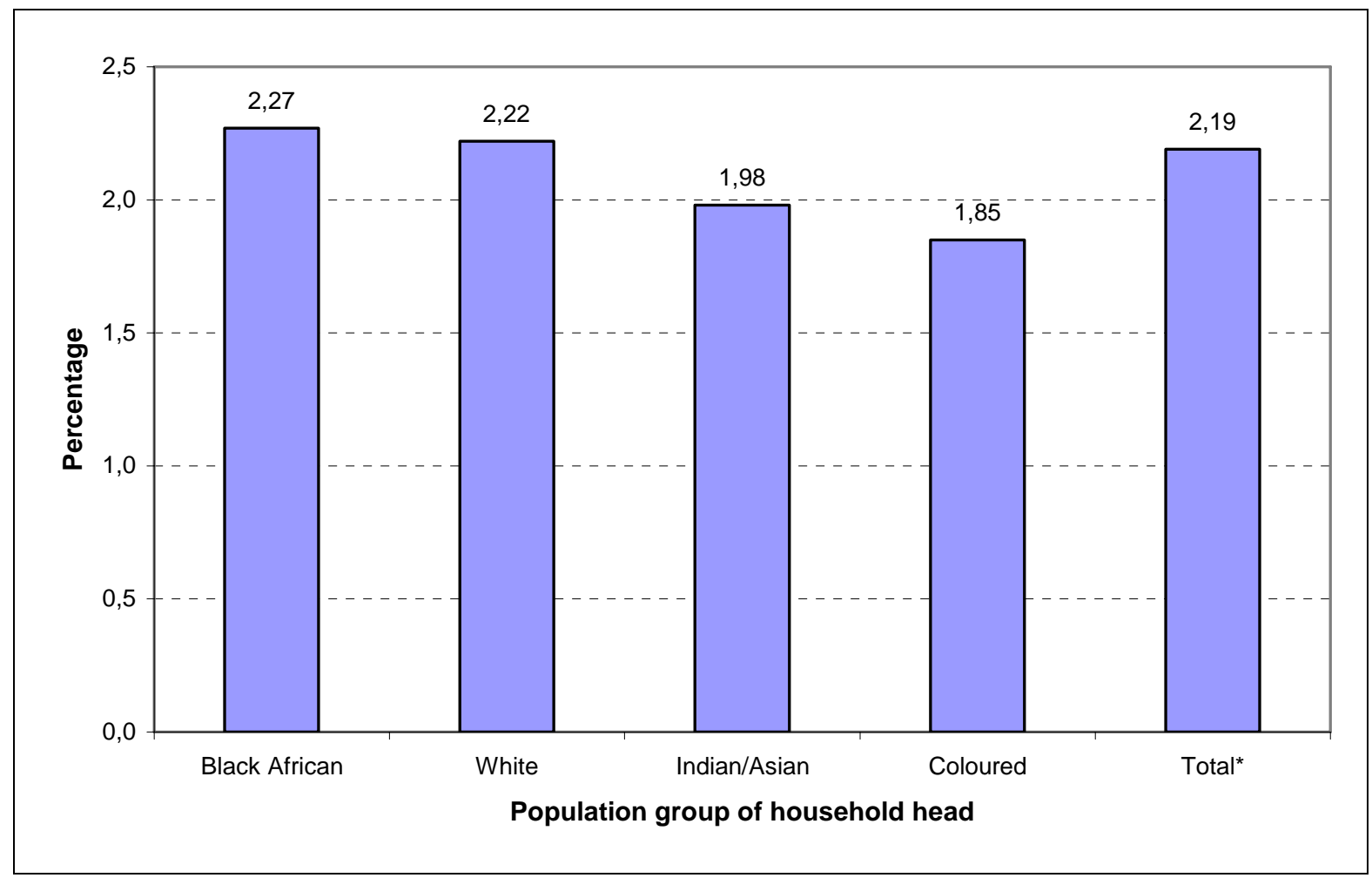

Total $^{\star}$ includes households with unspecified population group of household head

Figure J2 - Proportion of total household expenditure on restaurants and hotels by sex of household head

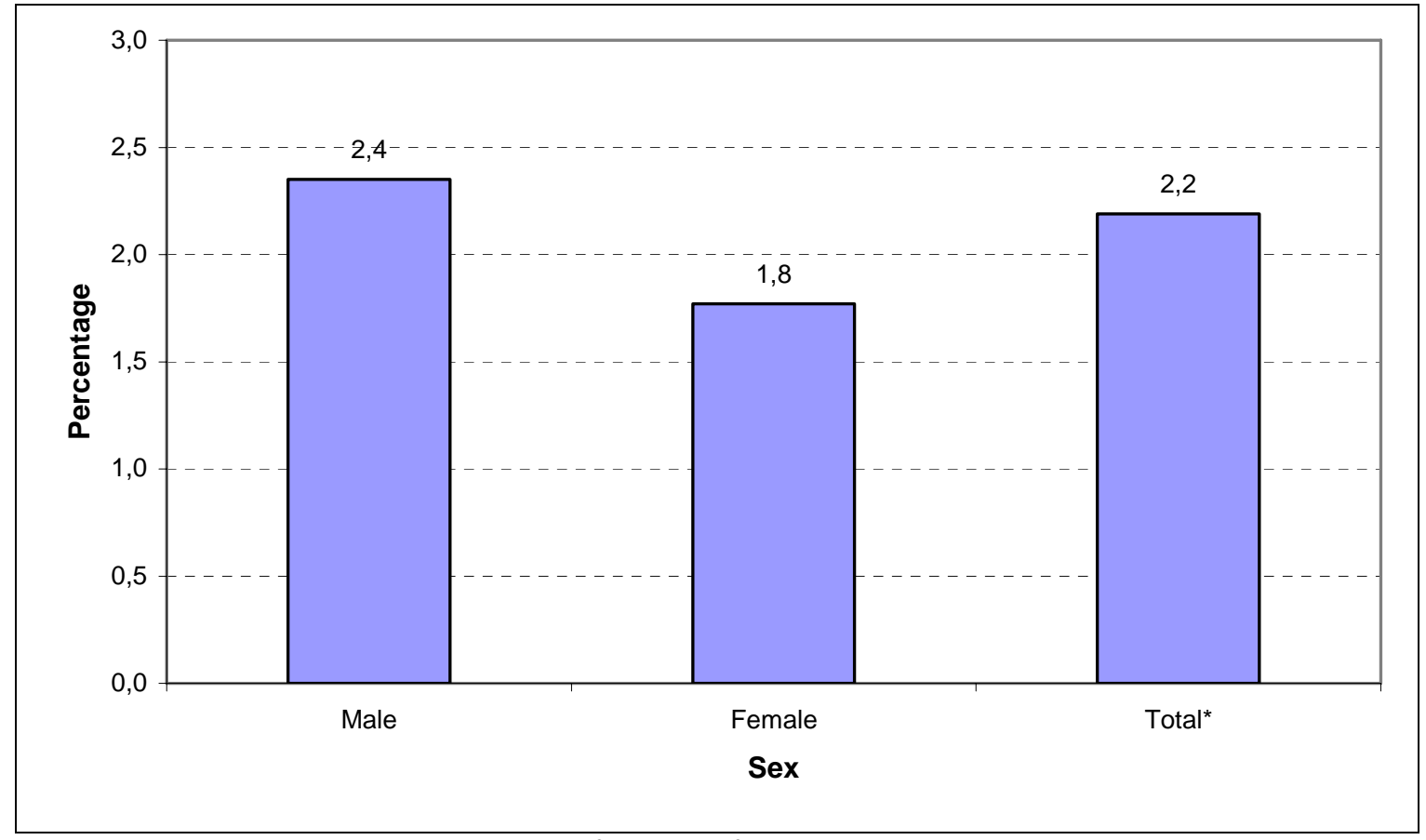

Total ${ }^{\star}$ includes households with unspecified sex of household head 
Figure J3 - Proportion of total household expenditure on restaurants and hotels by settlement type

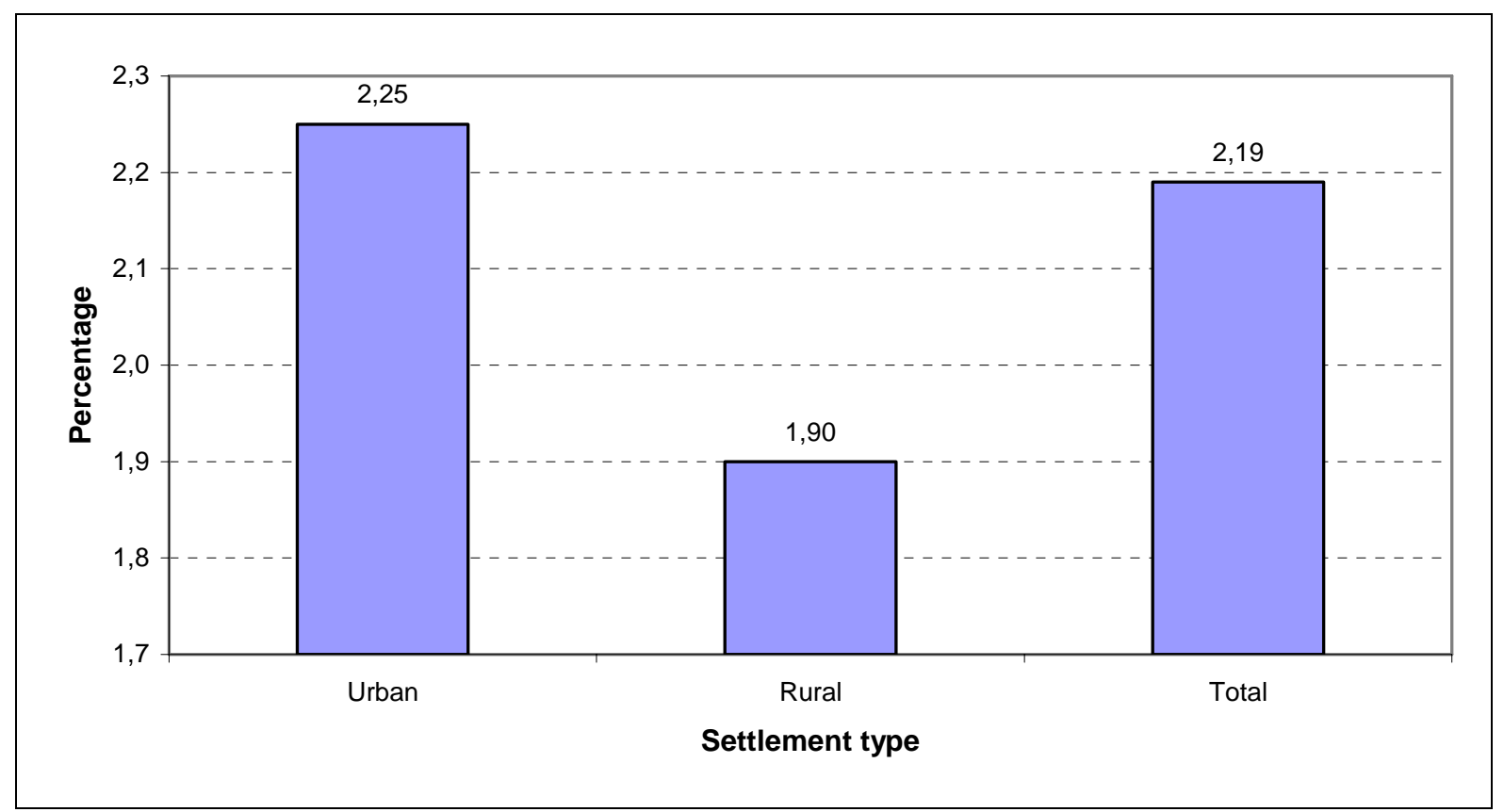

Figure $\mathrm{J4}$ - Proportion of total household expenditure on restaurants and hotels by province

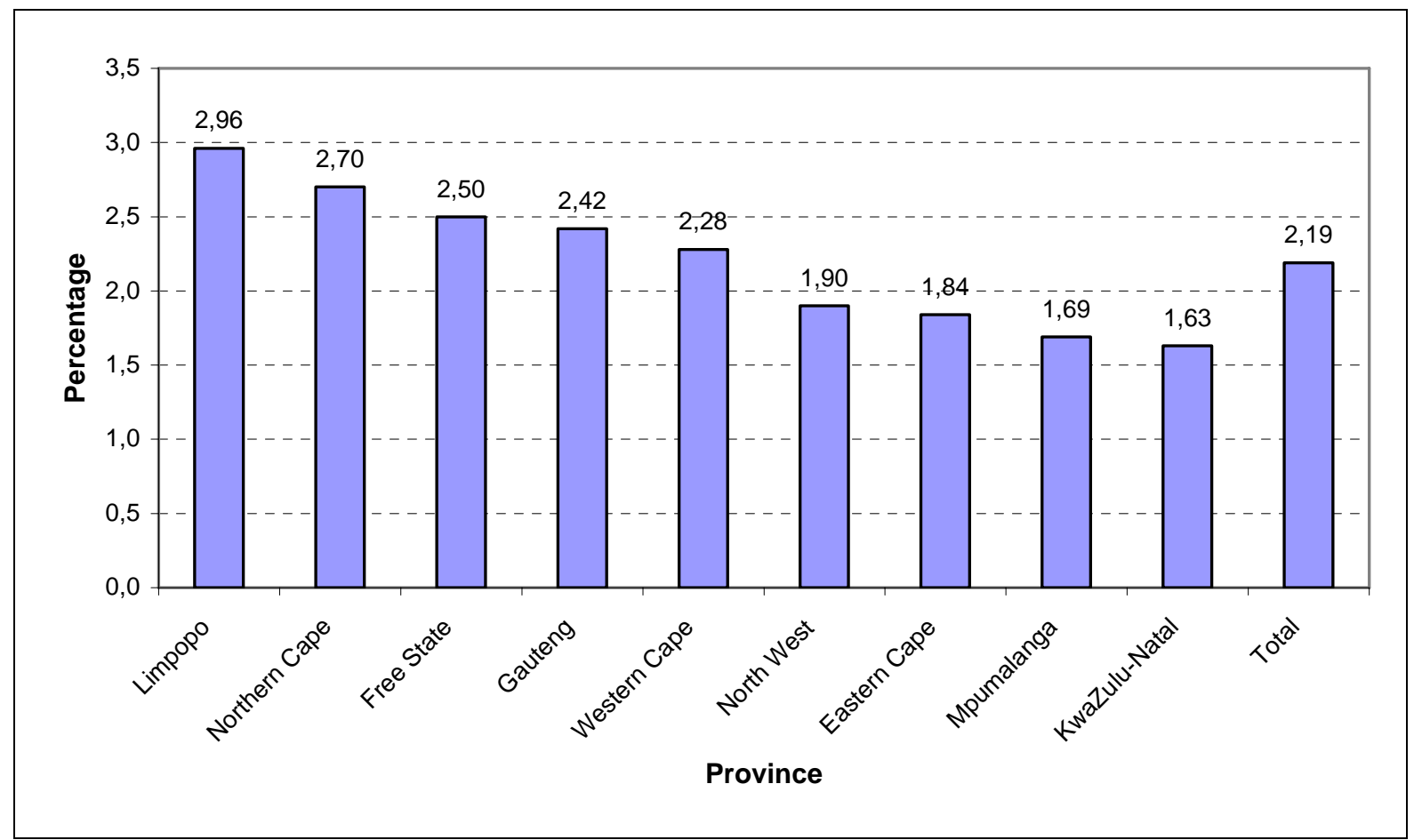


Figure K1 - Proportion of total household expenditure on miscellaneous goods and services by population group of household head

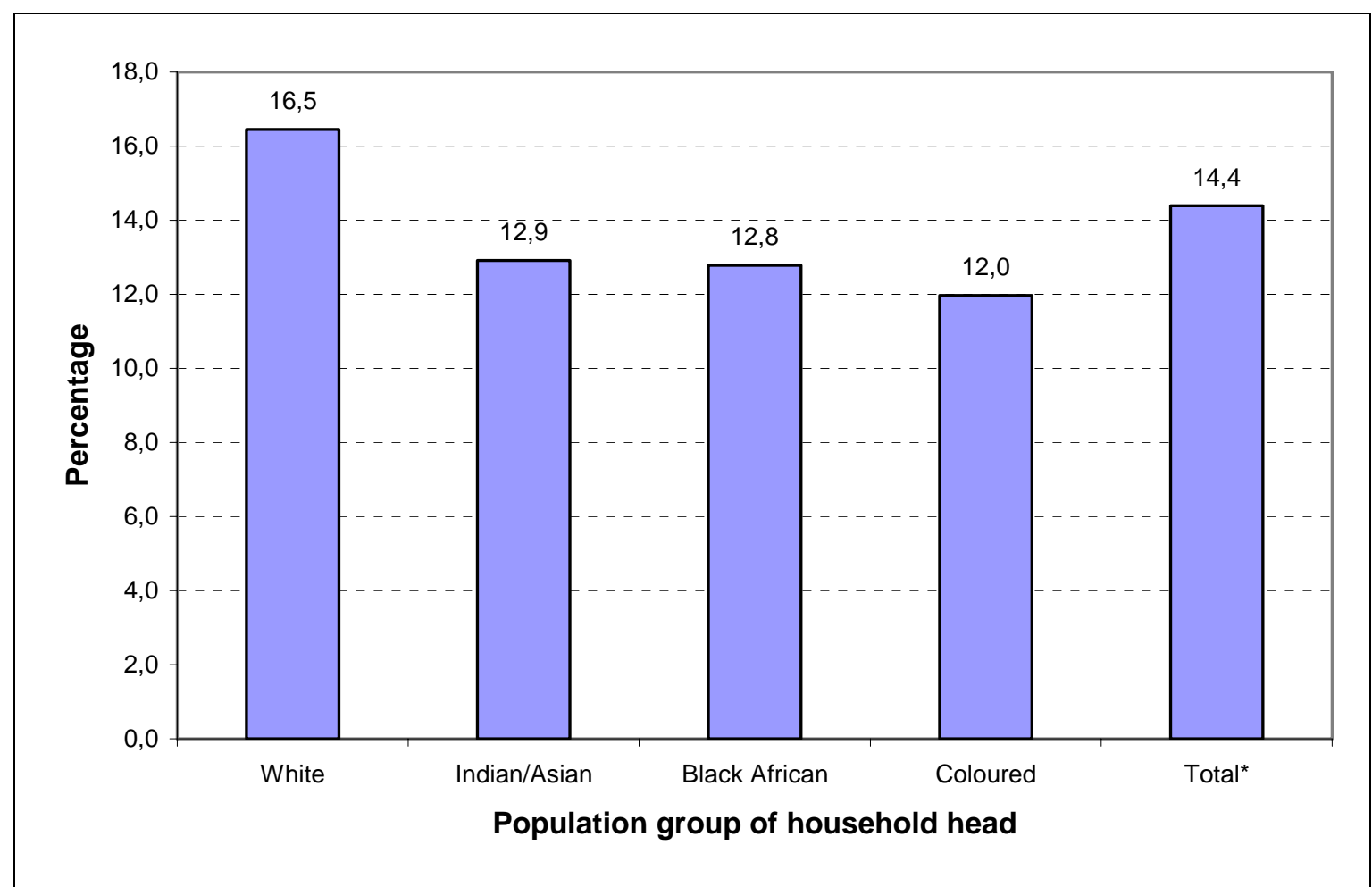

Total* includes households with unspecified population group of household head

Figure K2 - Proportion of total household expenditure on miscellaneous goods and services by sex of household head

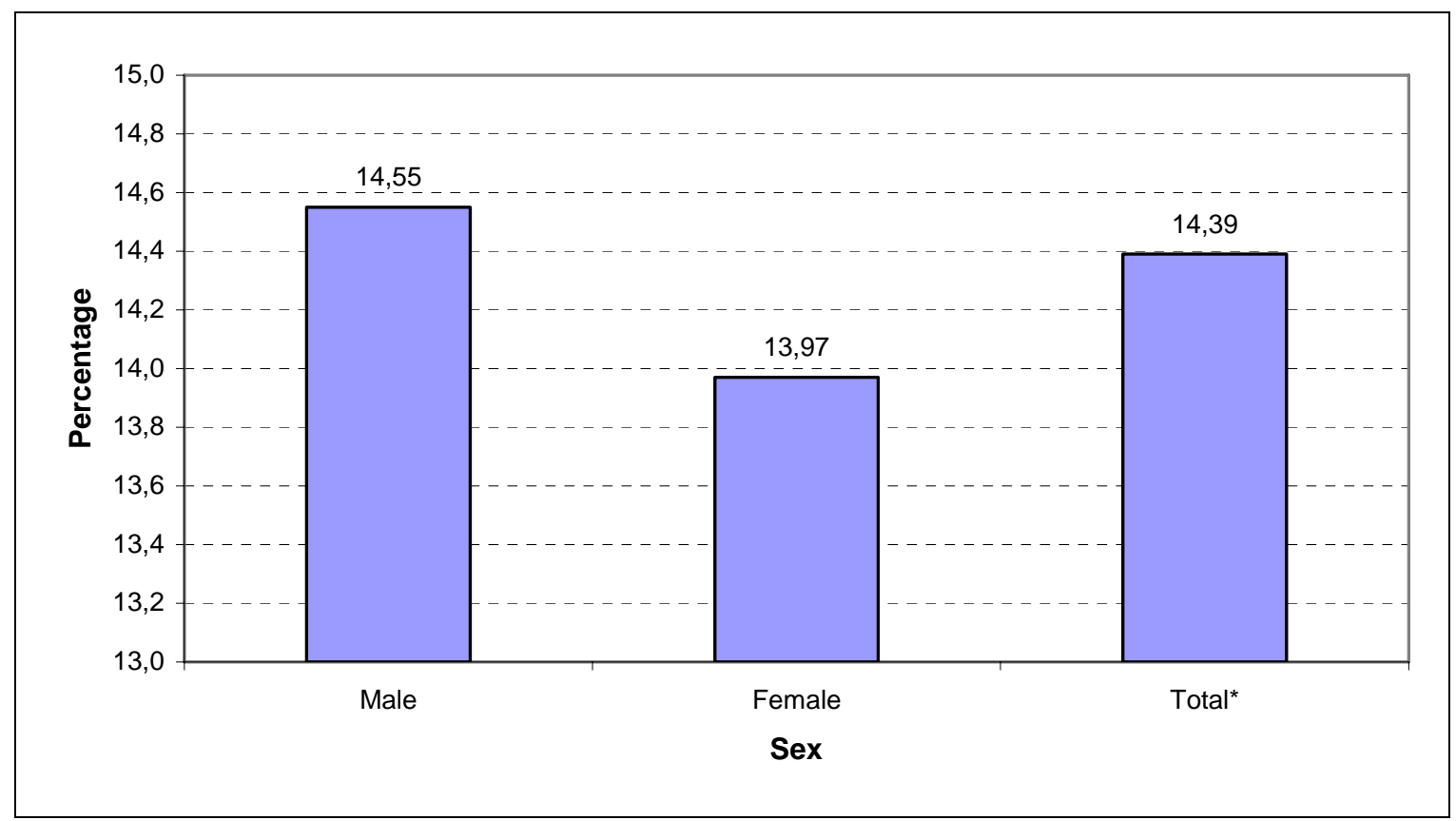

Total* includes households with unspecified sex of household head 
Figure K3 - Proportion of total household expenditure on miscellaneous goods and services by settlement type

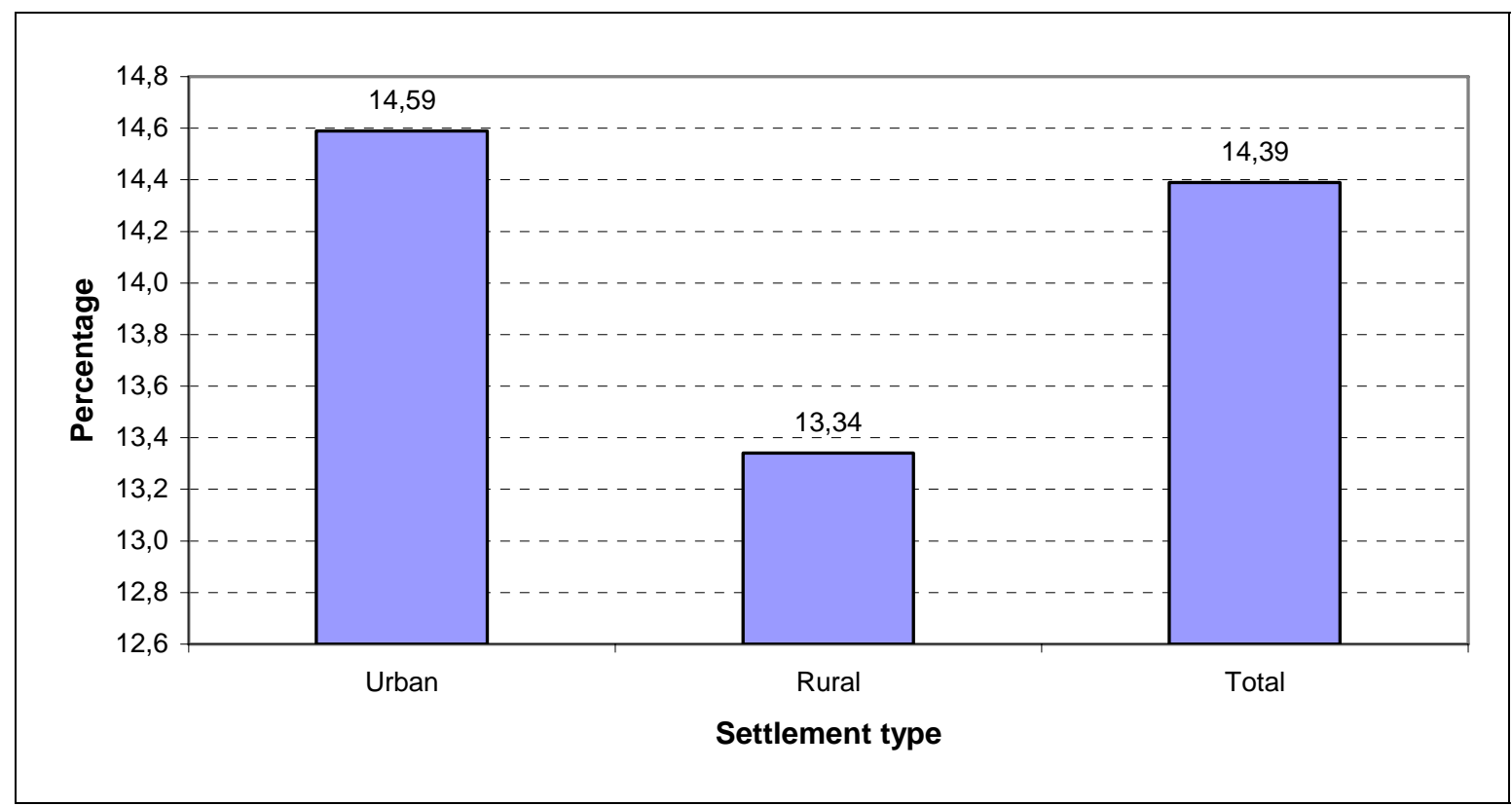

Figure K4 - Proportion of total household expenditure on miscellaneous goods and services by province

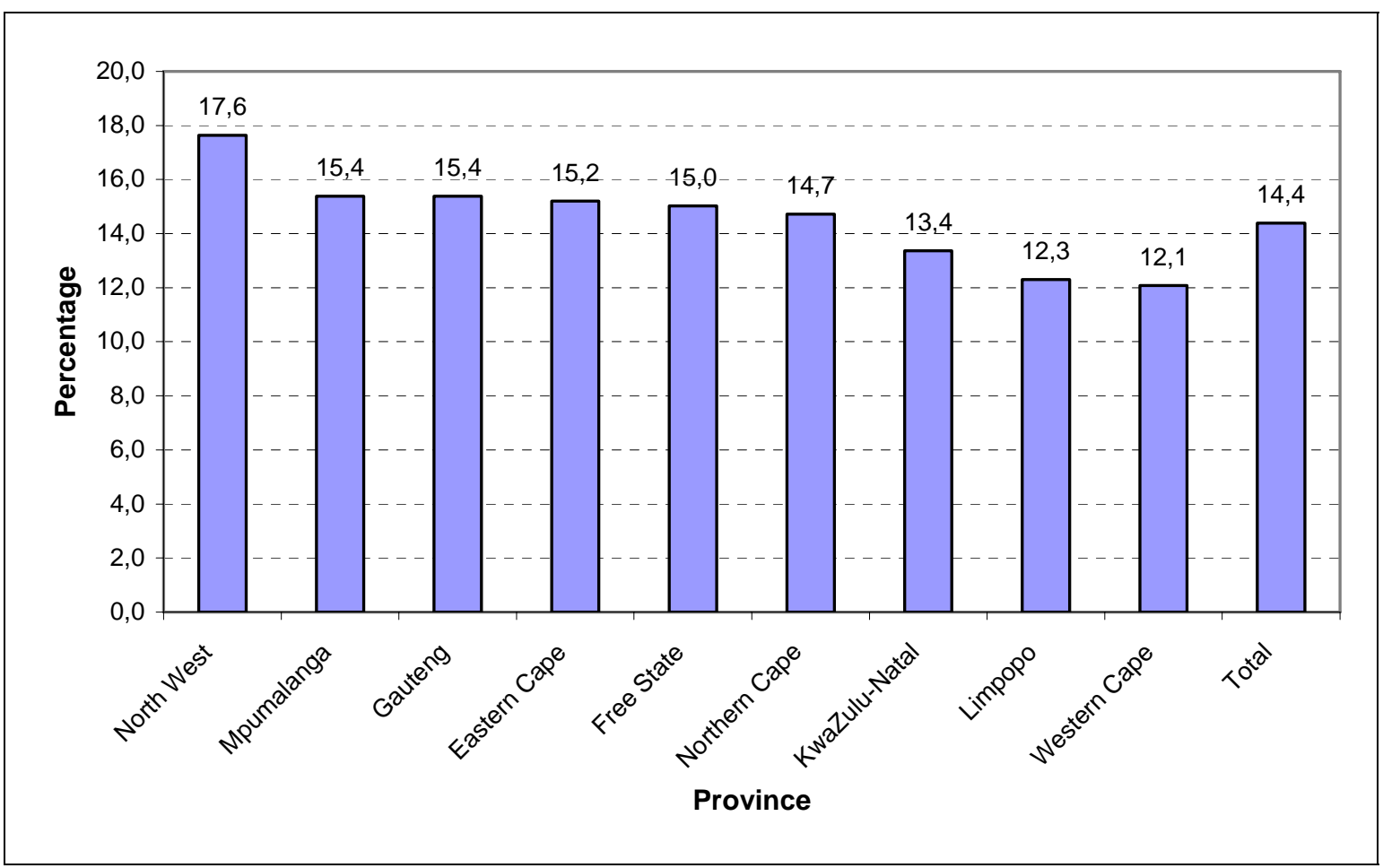


